UNIVERSIDADE DE SÃO PAULO

FACULDADE DE MEDICINA DE RIBEIRÃO PRETO

Lipid raft associated molecules modulate signal transduction and inflammatory mediator release in mast cells

Moléculas associadas aos lipid rafts modulam a transdução de sinal e a liberação de mediadores inflamatórios em mastócitos

Edismauro Garcia Freitas Filho

Ribeirão Preto 


\section{EDISMAURO GARCIA FREITAS FILHO}

\section{Lipid raft associated molecules modulate signal transduction and inflammatory mediator release in mast cells}

Moléculas associadas aos lipid rafts modulam a transdução de sinal e a liberação de mediadores inflamatórios em mastócitos

Tese apresentada à Faculdade de Medicina de Ribeirão Preto da Universidade de São Paulo para obtenção do título de Doutor em Ciências.

Área de concentração:

Biologia Celular e Molecular

Orientadora:

Profa. Dra. Maria Célia Jamur

Ribeirão Preto 
Autorizo a reprodução e divulgação total ou parcial deste trabalho, por qualquer meio convencional ou eletrônico, para fins de estudo e pesquisa, desde que citada a fonte.

Catalogação da Publicação

Serviço de Documentação

Faculdade de Medicina de Ribeirão Preto da Universidade de São Paulo

\section{FICHA CATALOGRÁFICA}

Freitas-Filho, Edismauro Garcia

Moléculas associadas aos lipid rafts modulam a transdução de sinal e a liberação de mediadores inflamatórios em mastócitos (Lipid raft associated molecules modulate signal transduction and inflammatory mediator release in mast cells) / Edismauro Garcia Freitas Filho; Orientadora: Profa. Dra. Maria Célia Jamur - 2019

175 f.: il.; $30 \mathrm{~cm}$.

Tese (Doutorado em Biologia Celular e Molecular) - Departamento de Biologia Celular e Molecular e Bioagentes Patogênicos. Programa de Pós-Graduação em Biologia Celular e Molecular. Faculdade de Medicina de Ribeirão Preto, Universidade de São Paulo, Ribeirão Preto, 2019

1. Mastócitos. 2. Mediadores inflamatórios. 3. Gangliosídeos derivados do GD1b. 4. Transdução de sinal. 5. Lipid rafts. 6. Análise proteômica. 7. RACK1. 8. Secreção regulada. 
Nome: Freitas-Filho, Edismauro Garcia

Título: Moléculas associadas aos lipid rafts modulam a transdução de sinal e a liberação de mediadores inflamatórios em mastócitos

Title: Lipid raft associated molecules modulate signal transduction and inflammatory mediator release in mast cells

Tese apresentada à Faculdade de Medicina de Ribeirão Preto da Universidade de São Paulo para obtenção do título de Doutor em Ciências. Área de concentração: Biologia Celular e Molecular.

\section{Aprovado em:}

\section{Banca Examinadora}

Prof(a). Dr(a).:

Instituição:

Julgamento:

Assinatura:

Prof(a). Dr(a).:

Instituição:

Julgamento:

Assinatura:

Prof(a). Dr(a).:

Instituição:

Julgamento:

Assinatura:

Prof(a). Dr(a).:

Instituição:

Julgamento:

Assinatura: 


\section{Aninha e Suas Pedras}

Não te deixes destruir...

Ajuntando novas pedras

e construindo novos poemas.

Recria tua vida, sempre, sempre.

Remove pedras e planta roseiras e faz doces. Recomeça.

Faz de tua vida mesquinha um роета.

E viverás no coração dos jovens e na memória das gerações que hão de vir. Esta fonte é para uso de todos os sedentos.

Toma a tua parte.

Vem a estas páginas

e não entraves seu uso

aos que têm sede. 
DEDICATÓRIA 
Aos meus pais, Maisa e Edismauro, exemplos de dedicação, trabalho, e amor incondicional. 
A jornada acadêmica requer esmero de seu peregrino, e eu, sozinho, seria incapaz de realizálo. Muitos são os que contribuíram para a realização deste trabalho. Portanto, considero esta seção uma das mais importantes...

\section{Agradeço de coração:}

Aos meus pais, Maisa Carvalho Garcia e Edismauro Garcia Freitas, pela vida que me deram, pela criação, pela dedicação e amor, que nunca deixaram faltar. Obrigado meus pais pelos vossos esforços e empenhos que tornaram possível minha formação acadêmica. Agradeço pelas inúmeras vezes em que meu pai me assistiu permitindo com que eu alcançasse voos cada vez maiores. Quero agradecer também aos abraços e os incansáveis dizeres de minha mãe a sempre me abençoar pedindo que nosso Senhor em vossa misericórdia me protegesse. Obrigado pelo apoio, confiança e pelo orgulho que sentem de mim. Eu também me orgulho muito de vocês.

Ao meu irmão, Edismair, cujo papel de irmão mais velho é tão bem representado. Obrigado pela proteção e cuidado. Mais ainda, obrigado pelos dois anjos que colocastes em nossa família. Meus sobrinhos, Gabriel e Alice, vocês são os sobrinhos mais lindos e perfeitos que alguém poderia ter, o "titio filho" ama vocês. À minha irmã, Mariana, obrigado por somar forças à proteção de nossa família. Agradeço também meus cunhados Michelly Cristina e Marcos. Amo muito todos vocês!

Às minhas madrinhas, Altair e Gislaine, mulheres de fibra e exemplos de resiliência. Obrigado pelo apoio de sempre. Às minhas primas, em especial Bárbara, Elizandra e Vanessa, meu trio de garotas superpoderosas.

À toda a família Garcia Gomes Freitas e a família Carvalho, obrigado pelo carinho e torcida.

"Que a família comece e termine sabendo onde vai E que o homem carregue nos ombros a graça de um pai Que a mulher seja um céu de ternura, aconchego e calor E que os filhos conheçam a força que brota do amor Abençoa Senhor as famílias, amém! Abençoa Senhor, a minha também" Oração pela família - Padre Zezinho 


\section{Meus agradecimentos especiais:}

À minha estimada orientadora, Profa. Dra. Maria Célia Jamur, pela atenção, pelos ensinamentos, pelas discussões e sugestões tão importantes para a realização deste trabalho. Muito obrigado pela oportunidade de crescimento e formação científica, pela confiança, pelo suporte e principalmente toda consideração. A senhora é exemplar e muito especial para mim.

À minha segunda orientadora, Profa. Dra. Constance Oliver, meus sinceros agradecimentos pela sua participação no trabalho e também na minha formação, pelas dicas valiosas, pelo tempo dedicado às leituras e correções, e também pelos seus abraços tão especiais de apoio e carinho.

I would like to thank Dr. Indu Suresh Ambudkar for having fully supported me during my fellowship at NIDCR, NIH, Bethesda, MD, USA. I am so grateful for your outstanding supervision and for the fascinating discussions. Your expertise, in addition to all the lab support, were important to conclude this study.

Aos docentes que aceitaram fazer parte da Banca Examinadora da defesa deste trabalho, muito obrigado pela disponibilidade e atenção dispensada.

Agradeço também a todos os professores que, direta ou indiretamente, contribuíram para minha formação acadêmica durante o doutorado. 


\section{Agradeço imensamente,}

Aos meus queridos amigos:

Nathanne Ferreira, Ludmila Lima, Pedro Afonso, Brisa Burgos, Rhéure Alves, Karla Bianca, Camila Pereira, Camila Zanotto e Vania Olivon. Sou grato pela companhia, pelos abraços, pelas conversas, pelos churrascos, pelas viagens, pelo amor fraterno. Nosso amparo incondicional nesta jornada é precioso e essencial. Ainda, obrigado Pedro, pela parceria e por impulsionar o que há de melhor em mim (te amarei de janeiro a janeiro).

Amigos goianos do pé rachado e do coração, jamais nos esqueçamos:

“...Um amigo é uma joia tão rara. Não se encontra em qualquer lugar.

É um tesouro guardado na alma de quem sabe amar.

Na alegria quando é pra sorrir. Na tristeza quando é pra chorar.

Um amigo é a força que leva você a lutar.

No momento em que a solidão faz silêncio no seu coração

sempre existe um amigo trazendo carinho nas mãos.

Somos amigos pra valer. Amigos sempre vamos ser...

E quem dúvida pode ver. Somos amigos!”

Canção da Amizade - Chitãozinho e Xororó

Aos meus amigos do Laboratório de Biologia Celular e Molecular dos Mastócitos:

Antônio Borges, Clarissa Valim, Valéria Barbosa, Vanina Toso, Vivian Mazucato e William Maximiano. E em especial à Ana Carolina Santana, Devandir Antônio de Souza Junior e Elaine Zayas que me acompanharam de perto nessa reta final. Meus sinceros agradecimentos pelo ótimo convívio, partilha, cafés, e acima de tudo, respeito. Guardarei um pouco de vocês sempre comigo. Foi uma honra e privilegio fazer parte da Turma dos Mastócitos.

Aos amigos de longa data:

Carolinne Franco, Jéssica Costa, Gabriela Latorre, e Marcos Roberto. Agradeço por todo o apoio e torcida.

Timna Varela, um presentinho em forma de princesa que a vida me deu. Obrigado por estar do meu lado, pela preocupação e proteção! Você é muito especial para mim. 
Mariana Tomazett, Lílian Baeza, e Laurine Pigosso, obrigado por me receberem sempre de braços abertos e bom humor. Adoro muito vocês!

Aos amigos que Ribeirão Preto me presenteou:

Daniel Rodrigues, Iuly Gomes, Natália Barbosa, Larissa Dias, Débora Akemi, Daniela Lescano, Bárbara Yasmin, Jackeline Araújo, Vanessa Arfelli, Nikollas Moreira, Procópio Filho, Flávia Matsuo, e Taiz Brasil. E também minhas crias científicas Brenda Gabriele e Luiz Augusto. Os dias ganham mais alegria na presença de vocês. Muito obrigado pela amizade e carinho!

I would like to thank all my friends from the volleyball group at the NIH, Ina Marina, Ghanwa Khawaja, Maria landron, Jennifer Zhu, Jens Kalchschmidt, Max Bley, Trinh Pahm, Rogers Palomino, and Lucia Bettedi. Moreover, in a very special way, to Maria Carolina and Sonia Zicari, I cannot thank you enough, you rock! Thanks for the opportunity to play with all of you. Became friends was one of the most amazing things that happened. I grateful to have met you!

Saber Viver

Não sei... se a vida é curta ou longa demais para nós, mas, sei que nada do que vivemos tem sentido, se não tocamos o coração das pessoas.

Muitas vezes basta ser:

o colo que acolhe, o braço que envolve, a palavra que conforta, o silêncio que respeita, a alegria que contagia, a lágrima que corre, o olhar que acaricia, o desejo que sacia, o amor que promove.

E isso não é coisa de outro mundo, é o que dá sentido à vida.

É o que faz com que ela não seja nem curta, nem longa demais, mas que seja intensa, verdadeira, pura enquanto ela durar.

Cora Coralina 


\section{Agradeço ainda:}

À minha primeira orientadora, Profa. Dra. Cecília Nunes Moreira. Obrigado pelas primeiras oportunidades de pesquisa, pelos incentivos, confiança, e exemplo de sua doutrina idônea. As nossas colaborações e contato presente fortificam ainda mais nossa amizade.

Aos docentes Profa. Dra. Maria Cristina Roque Barreira, Profa. Dra. Célia Maria de A. Soares, Prof. Dr. Clayton Borges, Prof. Dr. Eduardo M. Rego, Profa. Dra. Cristiane M. de Gaitani, e a Profa. Dra. Rita de Cássia Aleixo Tostes Passaglia pela disponibilidade de seus laboratórios.

Às funcionárias Me. Elizabete Rosa Milani e Dra. Roberta Rosales obrigado pela amizade, carinho, e pelo treinamento e apoio técnico nos ensaios de microscopia confocal, e na utilização, respectivamente, do Laboratório Multiusuário de Microscopia Confocal (LMMC), FAPESP 2004/08868-0, e do Laboratório Multiusuário de Microscopia Multifoton (LMMM).

Aos funcionários Maria Dolores Seabra Ferreira, José Augusto Maulin e Maria Teresa Picinoto Maglia, pelo apoio técnico nos ensaios de microscopia eletrônica e na utilização do Laboratório Multiusuário de Microscopia Eletrônica; LMME, FAPESP-EU 09/54013-0.

À funcionária Tânia Paula Aquino Defina, pelo treinamento e apoio técnico nos ensaios de PCR tempo real e na utilização do Laboratório Multiusuário de Biologia Molecular.

Aos funcionários Dra. Priscila Scheucher, Dr. Anderson Roberto de Souza, Vani Maria Alves, Sandra Maria Oliveira Thomaz, Me. Carla Pavan, pela disponibilidade e auxílio técnico-científico.

I would like to thank Dr. William D. Swaim (NIDCR Imaging Core, NIH, Bethesda, MD) for assistance with the confocal and high resolution microscopy; Dr. Krishna Prasad Subedi (NIDCR; NIH) for assistance with calcium experiments; and Dr. Hwei Ling Ong (NIDCR; NIH) for having supported me in everything I needed with respect to Dr. Indu's lab, your knowledge is incredible and I appreciate that you took the time to share it. 
À secretária da pós-graduação Gabriela Bunhotto Zamoner agradeço a permanente disponibilidade e serviços prestados.

Às secretárias do Departamento de Biologia Celular e Molecular e Bioagentes Patogênicos, Lúcia Helena Picinato Raphael e Camila Fabris, obrigado pelos ótimos serviços prestados.

À Universidade Federal de Goiás (UFG) - Regional Jataí, hoje UFJ, pela minha formação profissional.

À Faculdade de Medicina de Ribeirão Preto (USP) pela minha formação acadêmica.

Às agências de fomento: CAPES, CNPq, FAEPA, e em especial a FAPESP, pelo apoio financeiro à realização deste trabalho (Processos 2015/16673-0; 2016/21988-2).

e...

"Pensa em Deus, refugia-te em Deus, espera por Deus e confia em Deus, porquanto, ainda mesmo quando te suponhas a sós, em meio de tribulações incontáveis, Deus está conosco e com Deus venceremos." Emmanuel, psicografado por Chico Xavier 
“I was here. I lived, I loved. I was here. I did, I have done everything that I wanted and it was more than I thought it would be. I will leave my mark so everyone will know, I was here." Beyoncé Giselle Knowles Carter 


\section{INDEX}

ABSTRACT

RESUMO iv

1. INTRODUCTION 23

$\begin{array}{ll}\text { 1.1 Mast cells } & 24\end{array}$

1.2 Signal transduction pathway activated via the high affinity IgE receptor 26 (FcERI)

1.2.1 Calcium mobilization $\quad 28$

1.2.2 Cytoskeleton rearrangement in regulated secretion of preformed mediators $\quad 30$

$\begin{array}{ll}1.3 \text { Lipid rafts } & 31\end{array}$

1.3.1 Gangliosides and the mast cell specific gangliosides derived from GD1b 33

1.3.2 Proteomic profile of lipid rafts 34

1.4 Scaffold protein RACK1 (receptor for activated C kinase 1) 35

$\begin{array}{ll}\text { 2. AIMS } & \mathbf{4 0}\end{array}$

3. RESEARCH ARTICLES

3.1 Chapter I - Cross-linking mast cell specific gangliosides stimulates the release $\quad \mathbf{4 3}$ of newly formed lipid mediators and newly synthesized cytokines

3.2 Chapter II - Proteomic analysis of lipid rafts from RBL-2H3 mast cells $\quad 57$

3.3 Chapter III - RACK1 plays a critical role in F-actin dynamics and calcium $\quad \mathbf{8 3}$ mobilization in mast cell secretion

4. FINAL CONSIDERATIONS

5. CONCLUSIONS 129

$\begin{array}{ll}\text { REFERENCES } & 131\end{array}$

$\begin{array}{ll}\text { SUPPLEMENTAL FILES } & 146\end{array}$ 
ABSTRACT 


\begin{abstract}
FREITAS-FILHO, Edismauro Garcia. Lipid raft associated molecules modulate signal transduction and inflammatory mediator release in mast cells. 2019. $175 \mathrm{f}$. Thesis submitted to obtain the degree of Doctor of Science with a concentration in Cell and Molecular Biology - Ribeirão Preto Medical School, University of São Paulo, Ribeirão Preto, 2019.
\end{abstract}

Mast cells (MCs) play an essential role in innate immunity, allergy, and inflammation. The action of MCs is directly related to their release of bioactive mediators. Following activation of the high affinity IgE receptor (FceRI), initial signal transduction events occur in lipid rafts (LRs) in the plasma membrane. In order to better understand the important role of LR in MC function, attention was first directed towards the role of the MC specific GD1b-derived gangliosides present in LRs in modulating mediator release. Cross-linking these gangliosides with mAbAA4 activated MCs without inducing degranulation. However, ganglioside cross-linking resulted in the release of newly formed lipid mediators (prostaglandins D2 and E2) and newly synthesized mediators (interleukin-4, interleukin-6 and TNF- $\alpha$ ). These responses were respectively due to partial activation of the arachidonate cascade and induction of MAP Kinase phosphorylation and activation of transcription factors. It then was of interest to examine the protein composition of LRs from RBL-2H3 MCs by qualitative mass spectrometry. 949 different LR proteins were identified. Functional enrichment analysis demonstrated an intimate association of these proteins with cellular membrane compartments and an involvement with MC biological processes, especially those related to regulated secretion, organization of macromolecular complexes, and signal transduction. Moreover, in this LR proteome, RACK1 was identified for the first time in MCs. RACK1 is a multifaceted scaffold protein that is a critical hub for intracellular signaling and immunoregulatory responses. Therefore, it was important to characterize the functional role of RACK1 in MCs. RACK1 knockdown in RBL-2H3 MCs affected cell morphology and resulted in a drastic rearrangement of the actin cytoskeleton with increased basal and stimulus-induced degranulation. The cortical region of the RACK1 knockdown MCs had F-actin free cortical regions, which may facilitate fusion of $\mathrm{CD}_{6}{ }^{+}-$ secretory granules with the plasma membrane, thus explaining the increased levels of degranulation. Furthermore, RACK1 positively influences the release of newly synthesized mediators. Additionally, RACK1 depletion showed a profound impact on $\mathrm{Ca}^{2+}$-mobilization. In conclusion, this study demonstrates that the LR associated molecules, MC-specific GD1bderived gangliosides and the scaffold protein RACK1, modulate signal transduction and 
subsequent mediator release in MCs, providing additional information to elucidate the MC functions.

Keywords: Mast cells. Inflammatory mediators. Gangliosides derived from GD1b. Signal transduction. Lipid rafts. Proteomic analysis. RACK. Regulated secretion. 
RESUMO 


\section{RESUMO}

FREITAS-FILHO, Edismauro Garcia. Moléculas associadas aos lipid rafts modulam a transdução de sinal e a liberação de mediadores inflamatórios em mastócitos. 2019. 175 f. Tese apresentada à Faculdade de Medicina de Ribeirão Preto da Universidade de São Paulo para obtenção do título de Doutor em Ciências na área de concentração em Biologia Celular e Molecular, Faculdade de Medicina de Ribeirão Preto, Universidade de São Paulo, Ribeirão Preto, 2019.

Os mastócitos (MCs) desempenham um papel essencial na imunidade inata, alergia e inflamação. A função dos MCs é diretamente relacionada à liberação de seus mediadores bioativos. Após ativação do receptor de alta afinidade para $\operatorname{IgE}$ (FcєRI), os eventos iniciais da transdução de sinal inicial acontecem nos lipid rafts (LRs) da membrana plasmática. Com a intenção de melhor entender a importância dos LRs na função dos MCs, a atenção foi inicialmente voltada para o papel dos gangliosídeos derivados do GD1b, específicos de MCs e presentes nos LRs, na modulação da liberação de mediadores. O intercruzamento desses gangliosídeos através do mAbAA4 ativa os MCs sem induzir a desgranulação. Entretanto, o intercruzamento dos gangliosídeos resultou na liberação de mediadores lipídicos neoformados (prostaglandinas D2 e E2) e neossintetizados (interleucina-4, interleucina-6 e TNF- $\alpha$ ). Essas respostas foram resultantes, respectivamente, da ativação parcial da via do ácido araquidônico e indução da fosforilação das MAP kinases e ativação de fatores de transcrição. Posteriormente foi de interesse investigar as proteínas que compõe os LRs de MCs RBL-2H3 através da espectrometria de massa qualitativa. 949 diferentes proteínas foram identificadas nos LRs. A análise de enriquecimento funcional demonstrou uma íntima associação dessas proteínas com compartimentos celulares com membranas e um envolvimento com processos biológicos de MCs, especialmente aqueles relacionados à secreção regulada, organização de complexos macromoleculares e transdução de sinal. Ainda, nesse proteoma de LRs, a RACK1 foi identificada pela primeira vez em MCs. RACK1 é uma proteína adaptadora multifuncional e um eixo central crítico para a sinalização intracelular e respostas imunorregulatórias. Portanto, foi importante caracterizar o papel funcional da RACK1 em MCs. O knockdown de RACK1 em MCs RBL-2H3 afetou a morfologia celular e resultou em um drástico rearranjo do citoesqueleto de actina com aumento da desgranulação basal e induzida por estímulo. A região cortical dos MCs knockdown para RACK1 apresentaram áreas livres de F-actina, o que pode facilitar a fusão de grânulos secretórios $\mathrm{CD} 3^{+}$com a membrana plasmática, explicando desta 
forma os níveis aumentados de desgranulação. Ainda, a RACK1 influencia positivamente a liberação de mediadores neossintetizados. Adicionalmente, a depleção de RACK1 demonstrou um impacto expressivo na mobilização de $\mathrm{Ca}^{2+}$. Concluindo, esse estudo demonstra que moléculas associadas aos LRs, os gangliosídeos derivados do GD1b específicos de MCs e a proteína adaptadora RACK1, modulam a transdução de sinal e a subsequente liberação de mediadores em MCs, fornecendo informações adicionais para a compreensão das funções de MCs.

Palavras-chave: Mastócitos. Mediadores inflamatórios. Gangliosídeos derivados do GD1b. Transdução de sinal. Lipid rafts. Análise proteômica. RACK1. Secreção regulada. 
INTRODUCTION 


\section{INTRODUCTION}

\subsection{MAST CELLS}

Mast cells (MCs) are multifunctional immune cells that participate in both innate and adaptive immunity as well as in inflammatory processes (Anand et al., 2012; Gilfillan and Beaven, 2011; Krystel-Whittemore et al., 2015; Pejler, 2019; Settipane et al., 2013). One of the primary roles of MCs is to act as sentinels of the surrounding environment, with the ability to respond to an insult to the host and initiate a rapid coordinated response through the release of various mediators. MCs have beneficial functions in homeostasis, host protection, tissue repair, angiogenesis, wound healing, parasitic elimination and viral infection (Caslin et al., 2018; de Souza et al., 2012; Galli and Tsai, 2008; Marshall, 2004). However, the effects of MC mediators can be deleterious for the host in situations when a tissue insult is repeated or continuous. It is therefore not surprising that MCs have been implicated in pathophysiology of many diseases including asthma and allergy, anaphylactic reactions, atopic dermatitis, atherosclerosis and mastocytosis (Galli, 2016; Méndez-Enríquez and Hallgren, 2019; Reuter et al., 2010). MCs are also involved in autoimmune diseases and diseases related to neuronal, gastrointestinal and cardiovascular systems (Hermans et al., 2019; Jones et al., 2019; Luker et al., 2019).

Similar to blood cells, MCs are derived from pluripotent hematopoietic stem cells, but different from many other hematopoietic cells which are released into the systemic circulation as mature cells, MCs leave the bone marrow as progenitors and migrate to peripheral sites where they complete their maturation (Jamur et al., 2005; Jamur et al., 2010). MCs are a heterogeneous cell population. This cellular heterogeneity is seen across species, between different organs, and even within the same tissue (Jamur and Oliver, 2011). This marked variability in phenotype is driven by the interaction with their local environment, including tissue matrix and resident cells, which affects their development, mediator content, ultrastructure, immunological and non-immunological activation and pharmacological responsiveness (Bradding, 2009; Jamur et al., 2005; Yong, 1997). MCs are widely distributed throughout vascularized tissues, particularly beneath or within epithelia and in close proximity to blood vessels and nerves. Moreover, MCs are increased at the interface between the host and the external environment, such as in skin, airways and the gastrointestinal tract (da Silva et al., 2014; Galli et al., 2008; Jamur et al., 2005). In rodents, MCs are divided into two phenotypes, connective tissue-type MCs (CTMCs) and mucosal MCs (MMCs). CTMCs are more mature and are found in the gut submucosa, the peritoneum and skin. MMCs appear more immature and are predominant in the intestinal 
mucosa (Enerbäck, 1966; Reynolds et al., 1990; Xing et al., 2011). Similarly, human MCs are divided into two subtypes according to their protease content, $\mathrm{MC}_{\mathrm{TC}}$ that express both tryptase and chymase and $\mathrm{MC}_{\mathrm{T}}$ that express tryptase. $\mathrm{MC}_{\mathrm{TC}}$ correspond to the $\mathrm{CTMCs}$ in rodents, and are located within connective tissues and are predominant in skin and intestinal submucosa (Bradding, 2009). $\mathrm{MC}_{\mathrm{T}}$ are roughly equivalent to rodent MMCs and are localized primarily in the alveolar wall and gastric mucosa (Irani et al., 1986; Kambe et al., 2004). The $\mathrm{MC}_{\mathrm{T}}$ and $\mathrm{MC}_{\mathrm{TC}}$ phenotypes can also be further divided into site-specific populations (Andersson et al., 2009).

The biological function of MCs depends largely on the type of stimuli they respond to and the profile of mediators they release. The amplitude and nature of the stimulus induced response is influenced by intrinsic MC characteristics and the composition of their microenvironment which directly affects the expression and activity of surface receptors and signaling molecules (Galli, 2016; Gilfillan and Beaven, 2011; Metcalfe et al., 2009). MC activation mediated by the high affinity $\operatorname{IgE}$ receptor (FceRI) is the best characterized form of MC activation (da Silva et al., 2014; Galli, 2016). However, MCs can also be activated independently of FceRI (Krystel-Whittemore et al., 2015). In addition to FceRI, MCs also express receptors for IgA and IgG (Finkelman et al., 2016), adenosine (Rudich et al., 2012), pathogen-associated molecular patterns (PAMPs) (Marshall, 2004; Sandig and Bulfone-Paus, 2012), endogenous peptides such as substance P (Ogawa et al., 1999), complements C3 and C5a (Nilsson et al., 1996), cytokines (SCF; TNF- $\alpha$; IL-33) (Columbo et al., 1992; Joulia et al., 2017), as well as physical stimuli (Boyden et al., 2016). MCs can also be activated by lectins binding to the cell surface (Barbosa-Lorenzi et al., 2016; Moreno et al., 2003). Recently, MC activation by MRGPRX2 receptor (MAS-related G protein-coupled receptor X2) and the mouse ortholog MRGPRB2 has gained attention due to the fact that they are the main receptors involved in pseudo-allergic reactions (Manorak et al., 2018; Subramanian et al., 2016).

MC activation via FceRI results in the release of a wide variety of preformed mediators that are stored in lysosome-like cytoplasmic secretory granules (SGs). The SG associated mediators include proteoglycans (heparin and chondroitin sulfates), biogenic amines (histamine and serotonin), lysosomal enzymes ( $\beta$-hexosaminidase, $\beta$-glucoronidadese, arulsulfatase), several serine and other proteases (tryptase- $\alpha,-\beta \mathrm{I},-\beta \mathrm{II},-\gamma, \alpha$ and $\beta$-chymases, cathepsin $\mathrm{G}$, and CPA3), and some cytokine as Interleukin(IL)-4, IL-6, IL-18, tumor necrosis factor (TNF), steam cell factor (SCF), vascular endothelial growth factor (VEGF) and transforming growth factor betta (TGF $\beta$ ). Preformed mediator release, most commonly, involves multiple membrane 
fusion events, including both granule-granule fusion and the fusion of SGs with the plasma membrane and it is initiated immediately after MC activation (Blank et al., 2014; Klein and Sagi-Eisenberg, 2019; Wernersson and Pejler, 2014).

The second class of mediators are the newly formed lipid mediators which are derived from arachidonic acid. They are synthesized de novo and released immediately (5-30 minutes) such as prostaglandins (PGD2 and PGE2), leukotrienes (LTC4 and LTB4), and plateletactivating factor (PAF), and released delayed until 4-6 hours after activation as is the case for prostaglandins. Newly formed lipid mediators can diffuse across membranes or be released by active transport through either organic anion transporters, the multidrug resistance-related proteins, or organic anion transporters of solute carrier superfamily (Diaz et al., 2002; Hirabayashi and Shimizu, 2000; Moon et al., 2014).

The third class is the newly synthesized mediators. They are released 8-12 hours after stimulation and require gene transcription and synthesis. They include various cytokines, chemokines and growth factors such as IL-1 $\beta$, IL-3, IL-4, IL-5, IL-6, IL-8, IL-13, IL-17A, TNF,VEGF, EGF, TGF- $\beta$, CXCL1, CXCL3, CXCL8, CCL2 (MCP-1), CCL3 (MIP-1 $\alpha$ ), CCL4 (MIP-1 $\beta$ ) and CCL5 (RANTES). Few studies have investigated the molecular mechanisms involved in secretion of newly synthesized mediators in MCs. However, release of newly synthesized mediators follows a pathway distinct from that of SG release and most likely occurs from small exocytic vesicles (Blank et al., 2014; Mukai et al., 2018).

The array of biologically active compounds released by MCs can mediate proinflammatory, anti-inflammatory and/or immunoregulatory effects. Therefore, their phenotypic and functional plasticity allows MCs to respond to distinct challenges associated with various immunological and pathological conditions (Galli, 2016; Grodzki et al., 2009; Marshall, 2004; Reuter et al., 2010; Wernersson and Pejler, 2014).

\subsection{SIGNAL TRANSDUCTION PATHWAY ACTIVATED VIA THE HIGH AFFINITY IgE RECEPTOR (FceRI)}

MC activation via FceRI is the most extensively studied mechanism of MC activation and long considered the most relevant to allergic disease (Galli, 2016; Krystel-Whittemore et al., 2015). FceRI is a tetrameric structure from the multichain immune recognition receptor (MIRR) family, which also includes the B cell receptor (BCR), the T cell receptor (TCR), and receptors for IgG, Fc $\gamma$ RI and Fc $\gamma$ RII (Pecht, 2018). These receptors contain an immunoreceptor tyrosine- 
based activation motif (ITAM) in their cytoplasmic C-terminal domains which are essential for initiating signal transduction (Metzger et al., 1986). FceRI is comprised of a $45 \mathrm{kDa} \alpha$ chain, which binds IgE, a $30 \mathrm{kDa} \beta$ chain subunit and two identical $10 \mathrm{kDa} \gamma$ subunits that are linked by a disulphide bond (Cambier, 1995; Metzger et al., 1986; Siraganian et al., 2010).

FceRI activation (Figure 1) occurs when multivalent antigen binds to antigen specific IgE previously bound to the FceRI $\alpha$ chain promoting the cross-linking of receptors and their consequently aggregation. FceRI cross-linking results in the translocation of receptors along with other signaling molecules into lipid rafts (Dráber and Dráberová, 2002; Holowka and Baird, 2001). Lipid rafts are microdomains in the plasma membrane that act as platforms for the aggregation of cell signaling components (Sezgin et al., 2017; Varshney et al., 2016). FceRI associates with Lyn, a member of Src family of protein tyrosine kinases (SFKs) in the lipid rafts. SFK Lyn transphosphorylates tyrosine residues in ITAMs and strongly binds to the phosphorylated FceRI $\beta$ chain. The phosphorylated ITAMs serve as binding sites leading to the recruitment of the protein tyrosine kinase (PTK) Syk to lipid rafts. PTKs Syk are themselves phosphorylated by recruited Lyn and Syk, promoting the Syk activation loop that results in fully activated Syk which begins several downstream signaling events. Syk phosphorylates the transmembrane adapter proteins (TRAPs) LAT1 (linker for activation of T cells) and LAT2 (NTAL; non-T cell activation linker) that play essential roles as scaffolds in organizing, coordinating, and propagating signals (Benhamou et al., 1992; de Castro et al., 2010; Kovárová et al., 2001; Siraganian et al., 2010; Suzuki et al., 2014)

Phosphorylated LAT serves as an anchor for numerous cytoplasmic proteins, including the enzymes phospholipase (PLC) $\gamma 1$ and PLC $\gamma 2$, and others adapter proteins such as Gads, Grb2, SLP-76 and Shc, Gab2, and guanine exchanged factor Sos and Vav. Phosphorylates Gab2 binds to p82 subunit of PI3K. The complex PI3K-Gab2 are translocated to the plasma membrane and induces the activation of Akt, the generation of $\mathrm{PI}(3,4,5) \mathrm{P}_{3}$ by phosphorylation of $\mathrm{PI}(4,5) \mathrm{P}_{2}$, and thereby provides tethering to proteins tec, Btk, and PLC $\gamma \mathrm{s}$ (Draber et al., 2011; Rivera et al., 2001; Siraganian et al., 2010; Suzuki et al., 2014). Activated PLC $\gamma 1$ and PLC $\gamma 2$ catalyzes the hydrolysis of membrane bound $\mathrm{PI}(4,5) \mathrm{P}_{2}$ to generate two second messengers, DAG (1,2-diacylglycerol) and $\mathrm{IP}_{3}$ (inositol-1,4,5-triphosphate), which leads to the activation of PKCs (protein kinase C), specially PKC $\alpha$ and PKC $\beta$, and calcium mobilization (Figure 1) (Holowka et al., 2012; Metcalfe et al., 2009; Tasaka et al., 1986b; Yanase et al., 2011). 


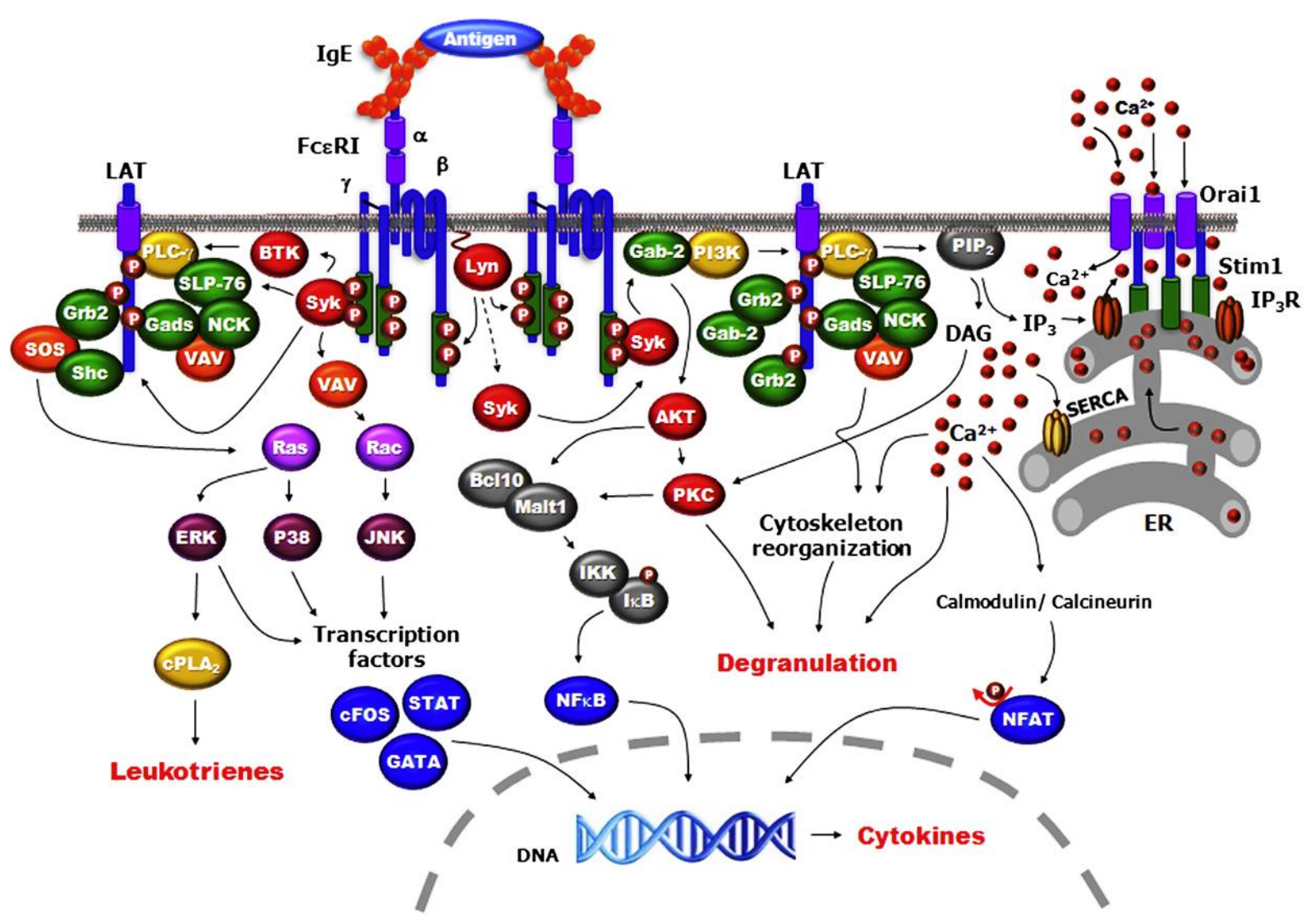

Figure 1. Main signaling events involved in mast cell activation via FceRI. (Adapted from Siraganian et al., 2010).

\subsubsection{Calcium mobilization}

The calcium mobilization induced by FceRI activation (Figure 2) begins when PLC $\gamma$ generated $\mathrm{IP}_{3}$ binds to its receptors $\left(\mathrm{IP}_{3} \mathrm{Rs}\right.$; most likely $\mathrm{IP}_{3} \mathrm{R} 1$ and 2$)$, located in the endoplasmic reticulum (ER) membrane, allowing the release of $\mathrm{Ca}^{2+}$ from ER stores. The changes in $\left[\mathrm{Ca}^{2+}\right]_{\mathrm{i}}$ from $\sim 0.1$ to $\sim 1 \mu \mathrm{M}$ mediated by FceRI stimulation are initiated immediately after receptor cross-linking . This depletion of $\mathrm{ER} \mathrm{Ca}^{2+}$ stores results in a transient elevation in intracellular calcium (Cohen et al., 2009; Dar and Pecht, 1992; Holowka et al., 2012). The $\mathrm{IP}_{3}$-induced depletion of $\mathrm{Ca}^{2+}$ from ER triggers store-operated calcium entry (SOCE) (Hoth and Penner, 1993).

SOCE is initiated by $\mathrm{Ca}^{2+}$ depletion from the ER which causes conformational changes in both luminal and cytosolic segments of stromal interaction molecule 1 (STIM1) in the ER membrane. This conformational change is due to the loss of $\mathrm{Ca}^{2+}$ binding to EF-hand motifs in a luminal domain of STIM1 that results in the clustering of STIM1 molecules. The oligomers of STIM1 are translocated to the cell periphery, aggregating within ER-plasma membrane (ERPM) junctions. These junctions are formed by close apposition of the ER and plasma membrane which is promoted when ER-residing STIM1 anchors to $\mathrm{PI}(4,5) \mathrm{P}_{2}$ in lipid raft domains (Baba 
and Kurosaki, 2008; Baba et al., 2008; Liou et al., 2005; Zhou et al., 2013). This process brings the ER closer to the plasma membrane which results in the recruitment of the tetraspan channel protein Orai1 [Orai1/ $\mathrm{Ca}^{2+}$-release activated channel (CRAC)M1], from other regions of the plasma membrane into these junctions (Di Capite et al., 2011; Prakriya et al., 2006; Vig et al., 2008). STIM1-Orai1 interactions occur through the biding of the Orail activating region (SOAR) in the C-terminal region of STIM1 with the N-terminus of the Orail channel and results in channel activation and, consequently, in a $\mathrm{Ca}^{2+}$ influx $\left(\mathrm{Ca}^{2+}\right.$ entry) and in a further increase in $\left[\mathrm{Ca}^{2+}\right]_{\mathrm{i}}$ (Calloway et al., 2009; Cohen et al., 2009; Holowka et al., 2016).

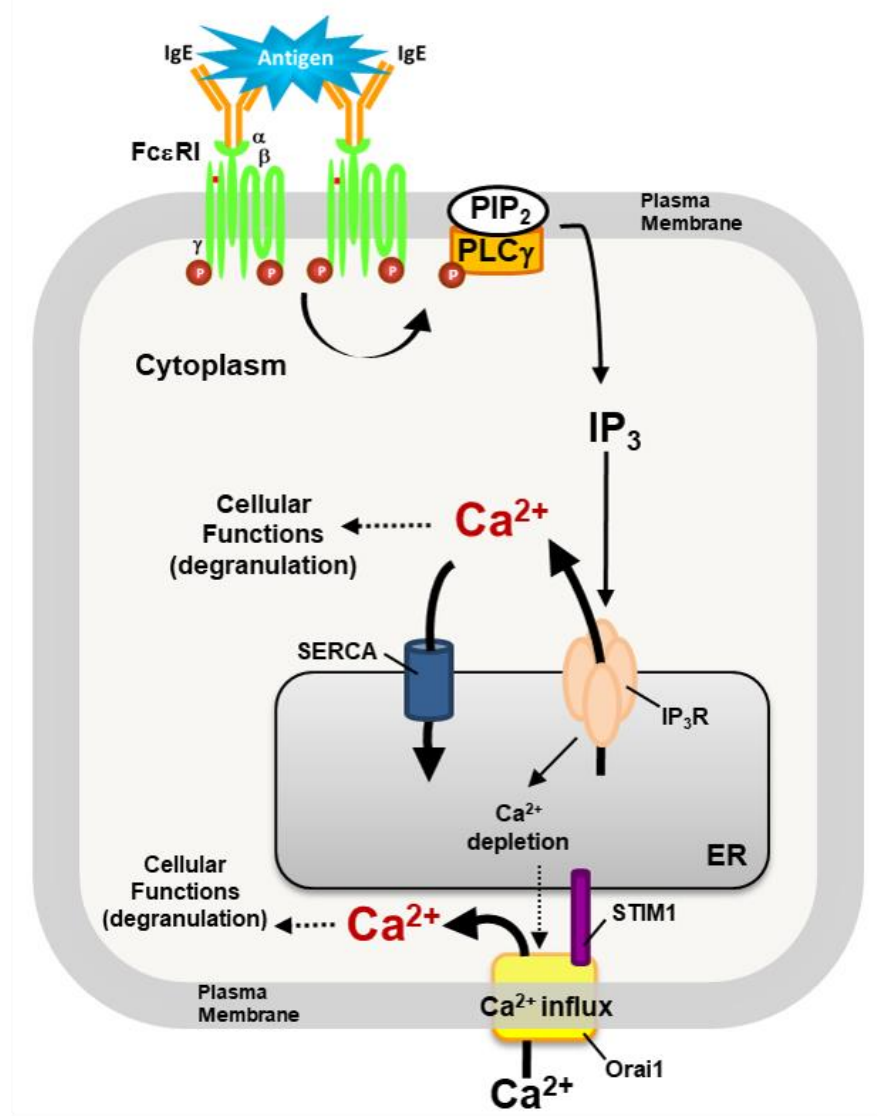

Figure 2. Signaling events in calcium mobilization induced by FeERI activation of mast cells. (Freitas-Filho, E. G.)

The voltage-dependent $\mathrm{Ca}^{2+}$ channels, the TRP channels, TRPC1 and TRPC3, can contribute to FceRI-stimulated $\mathrm{Ca}^{2+}$ entry in MCs (Cheng et al., 2013; Suzuki et al., 2010). TRPC1 may also aggregates with Orai1 and STIM1 within the same ER-PM junctions (Ambudkar et al., 2017; Holowka et al., 2016). $\mathrm{Ca}^{2+}$ influx is associated with membrane depolarization due in part to influx of $\mathrm{Na}^{+}$via the TRPC subfamily $\mathrm{M}$ member 4 . Cells are then repolarized through active transport of $\mathrm{K}^{+}$through the $\mathrm{Ca}^{2+}$-activated $\mathrm{K}^{+}$channel, $\mathrm{iK}_{\mathrm{Ca}} 3$, which 
is essential for continued $\mathrm{Ca}^{2+}$ influx. Moreover, the calcium signaling in MCs is substantially attenuated and prolonged by uptake and release of $\mathrm{Ca}^{2+}$ from mitochondria stores. Antigen stimulation results in a rapid increase in mitochondrial $\mathrm{Ca}^{2+}$. As $\left[\mathrm{Ca}^{2+}\right]_{i}$ subsides, $\mathrm{Ca}^{2+}$ is released from mitochondria through an $\mathrm{Na}^{+} / \mathrm{Ca}^{2+}$ exchanger to further modulate the calcium signal (Furuno et al., 2015; Mark Duffy et al., 2004; Vennekens et al., 2007). SOCE is also important for replenishment of $\mathrm{Ca}^{2+}$ in the ER through the action of sarcoendoplasmatic reticulum $\mathrm{Ca}^{2+}$ ATPases (SERCA $2 \mathrm{~b}$ or 3) pumps (Figure 2) and uptake into mitochondria though the ruthenium red-sensitive MCU and MIUC1 channels. The increase in $\left[\mathrm{Ca}^{2+}\right]_{\mathrm{i}}$ is counteracted by the transport of $\mathrm{Ca}^{2+}$ through PMCA and $\mathrm{Na}^{+} / \mathrm{Ca}^{2+}$ exchangers present in the plasma membrane (Furuno et al., 2015; Ma and Beaven, 2009).

The FceRI induced calcium mobilization is characterized as a fast wave that is frequently followed by a series of $\mathrm{Ca}^{2+}$ oscillations (Cohen et al., 2009; Dar and Pecht, 1992). Besides the other calcium regulated process during $\mathrm{MC}$ activation, these oscillations in $\left[\mathrm{Ca}^{2+}\right]_{\mathrm{i}}$, in association to $\mathrm{PI}(4,5) \mathrm{P}_{2}$ lipid levels, drives the recruitment and fusion of SGs towards the plasma membrane through cytoskeletal dependent regulated secretion (Cohen et al., 2012; Wollman and Meyer, 2012).

\subsubsection{Cytoskeleton rearrangement in regulated secretion of preformed mediators}

MC activation via FceRI involves extensive cytoskeletal reorganization resulting in cell spreading and surface ruffling, adhesion to the substrate, migration and degranulation (ColinYork et al., 2019; Dráber et al., 2012; Klebanovych et al., 2019; Tasaka et al., 1986a; Tolarová et al., 2004; Wilson et al., 2016). The main structural components of the cytoskeleton in MCs are microtubules, formed by tubulin dimers, intermediate filaments formed primarily by vimentin, and microfilaments formed by actins (Dráber et al., 2012).

It is well established that organization and function of microtubules are essential for the translocation of SGs from the interior of the cell to the cell periphery where they can be released (Klebanovych et al., 2019; Nishida et al., 2005; Tasaka et al., 1991). Changes in microtubule length and dynamics during MC activation appears to be regulated by changes in $\left[\mathrm{Ca}^{2+}\right]_{\mathrm{i}}$ (Calloway et al., 2009; Sulimenko et al., 2015) and tyrosine phosphorylation of centrossomal proteins by Fyn and Syk (Dráberová et al., 1999; Sulimenko et al., 2006). In contrast, the role of intermediate filaments during MC activation is limited. Vimentin (type III intermediate filament protein) is the main component of intermediate filaments in MCs (Horny et al., 1988). In unstimulated MCs, vimentin filaments surrounding SGs in the cytoplasm. However, after antigen stimulation the intermediate filaments rapidly depolymerize (Izushi et al., 1992), 
suggesting that the absence of filaments facilitates SGs movement, thus facilitating degranulation (Nahm et al., 2003; Tasaka, 1994).

Microfilament rearrangement is a fundamental step in MC regulated secretion. MC activation via FceRI triggers a drastic reorganization of the actin cytoskeleton, opening spaces in the cortical F-actin to permit SG fusion with the plasma membrane (Frigeri and Apgar, 1999; Tolarová et al., 2004; Wilson et al., 2016; Wollman and Meyer, 2012). Studies combining atomic force and confocal microscopy with total internal reflection fluorescence microscopy (TIRFM), demonstrated that SG fusion occurs only at plasma membrane sites devoid of cortical F-actin (Deng et al., 2009). Moreover, drugs that inhibit actin polymerization, including cytochalasin D and latrunculin B, are known to enhance degranulation in MCs (Frigeri and Apgar, 1999; Nishida et al., 2005).

\subsection{LIPID RAFTS}

In MCs lipid rafts play a crucial role in FceRI activated signal transduction and consequent mediator release (Dráber and Dráberová, 2002; Holowka and Baird, 2015; Silveira E Souza et al., 2011). Lipid rafts are dynamic-ordered nanoscale assemblies of the plasma membrane and other intracellular membranes, enriched in certain classes of lipids and proteins. These raft microdomains are characterized by a high melting temperature and resistance to solubilization at low temperature in non-ionic detergents, such as Triton X-100 (Bieberich, 2018; Pike, 2009). Moreover, raft microdomains associate and dissociate on a sub second timescale, being variable in stability, size, shape, lifetime, and molecular composition (Bieberich, 2018; Enoki et al., 2018; Sezgin, 2017).

Lipid rafts arise from preferential interactions between saturated lipids, glycosphingolipids (such as gangliosides), sphingolipids (such as sphingomyelin), and cholesterol that give rise to a sterol-dependent liquid ordered phase $\left(L_{\mathrm{o}}\right)$. Under physiological conditions, $L_{\mathrm{o}}$ phase can coexist with a liquid disordered $\left(L_{\mathrm{d}}\right)$ phase which consists mainly of phospholipids (with unsaturated tails). Moreover, lipid rafts concentrate certain proteins, such as proteins with lipid modifications (Spalmitoylation, N-myristoylation, isoprenylation) and cholesterol-binding proteins on the cytoplasmic side and glycosylphosphatidylinositol (GPI)-anchored proteins on their outer leaflet. Proteins with transmembrane segments have been shown to be target to lipid rafts by amino acid sequences in their extracellular, transmembrane, or intracellular domains (Figure 3) (Dráber and Dráberová, 2002; Levental et al., 2010; Lingwood and Simons, 2010; Sezgin et al., 2017). 


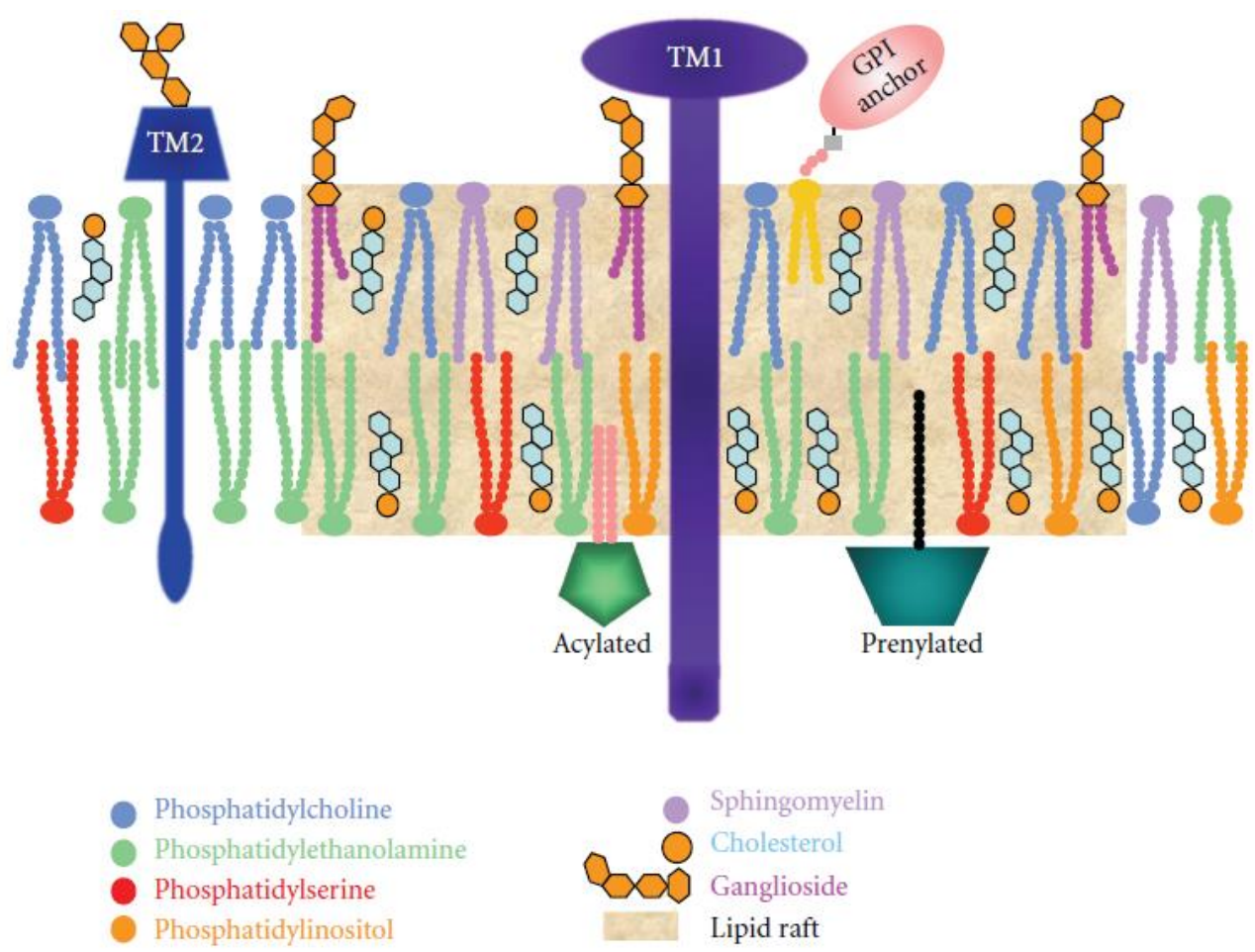

Figure 3. Diagrammatic illustration of a lipid raft. Lipid rafts are enriched in cholesterol, sphingolipids, and gangliosides. GPI anchored proteins, sphingomyelin, phosphatidylcholine, and gangliosides are present in the outer membrane leaflet. Proteins with lipid modifications (acylated and prenylated), phosphatidylserine, and phosphatidylethanolamine are present in the inner leaflet. Cholesterol is present in both leaflets and functions as a space filling molecule under the sphingolipid head groups. TM1, TM2, Transmembrane proteins 1 and 2. (Adapted from Silveira E Souza et al., 2011).

The exact nature of lipid rafts is extremely complex and the elucidation of how the selforganization of cellular macromolecules into structurally and functionally distinct domains has been one of the most intriguing and still incompletely resolved question in cell biology. Lipid rafts were proposed as functional lipid microdomains around 30 years ago even before the advance of experimental procedures that had helped to elucidate their existence (Masserini and Freire, 1986; Simons and van Meer, 1988). Recently developed techniques in isolating plasma membranes have confirmed that liquid-liquid phase coexistence in biological membranes and that its behavior is consistent with many aspects of the raft hypothesis (Levental and Levental, 2015; Sezgin, 2017; Suzuki et al., 2018). Moreover, these microdomains have been investigated not only in artificial membranes and in live cells, but also in live vertebrate organisms, such as zebrafish embryos (Owen et al., 2012).

Lipid rafts are an important platform for fundamental biological process in eukaryotic cells, including signal transduction, organization of trafficking and sorting mechanisms, vesicle secretion and endocytosis, entry of viruses, bacteria, and toxins. Lipid rafts concentrate molecules such as lipids, receptors, adaptors, kinases, scaffolding proteins, and cytoskeletal 
machinery that trigger complex events and coordinate diverse processes (Diaz-Rohrer et al., 2014; Head et al., 2014; Lingwood and Simons, 2010; Sezgin et al., 2017). Lipid rafts also modulate many other biological processes in MCs such as regulated secretion (Kato et al., 2003; Sheets et al., 1999; Silveira e Souza et al., 2008), endocytosis of FcعRI receptors (Mazucato et al., 2011; Oliver et al., 2007), development and recruitment of MCs (Jamur et al., 2005), and contribute to the preservation of MC structure (Holowka and Baird, 2015; Silveira E Souza et al., 2011).

\subsubsection{Gangliosides and the mast cell specific gangliosides derived from GD1b}

Gangliosides are important for lipid raft assembly and function (Kolter, 2012; Silveira E Souza et al., 2011). They are glycosphingolipids that are ubiquitous constituents of the outer leaflet of the plasma membrane as well as of some organelle membranes. Gangliosides are complex glycosphingolipids with strong amphiphilic character due to a saccharide headgroup and a double hydrophobic tail (Cantù et al., 2011; Sonnino et al., 2009).

In rodent MCs, the gangliosides derived from GD1b are specifically recognized by mAb AA4, which binds to one or two of the additional $\alpha$-galactosyl residues in their structure (Figure 4) (Guo et al., 1989). Gangliosides derived from GD1b were recognized as a component of lipid rafts in RBL-2H3 rat MCs (Basciano et al., 1986; Guo et al., 1989).

\section{Ganglioside GD1b}

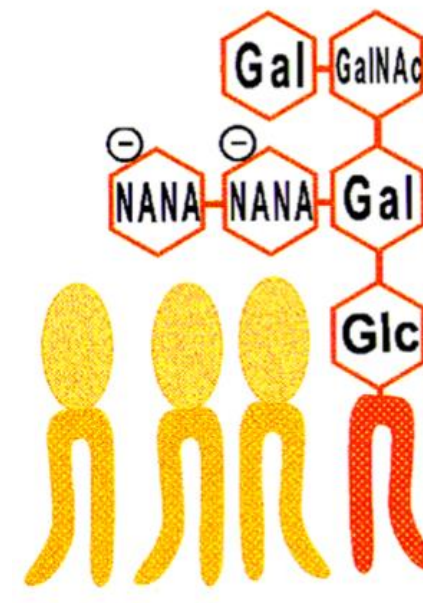

Derivative 1 recognized
by mAB AA4 $\longrightarrow$
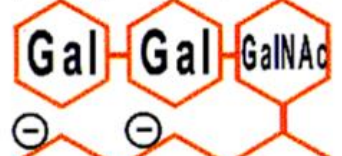
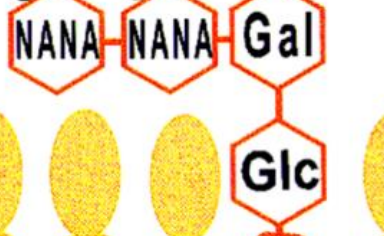

Figure 4. Schematic representation of ganglioside GD1b and its derivatives. Gal: galactose. GalNAc: $N$-acetylgalactosamine. Glc: glucose. NANA: $N$-Acetylneuraminic acid. (Adapted from Silveira e Souza et al., 2008b). 
The gangliosides derived from GD1b are intimately involved with FceRI-induced signal transduction in MCs. Pre incubation of RBL-2H3 MCs with mAbAA4 inhibits degranulation induced by FceRI stimulation in a time- and dose-dependent manner. This inhibition occurs at a very early step of upstream receptor tyrosine phosphorylation and it is not due to mAbAA4 blocking IgE-binding to the cells (Minoguchi et al., 1994; Stephan et al., 1997). The derivatives of the ganglioside GD 1b co-precipitating with SFK Lyn and, although mAb AA4 binds to sites close to FceRI, the association between these gangliosides and Lyn was not mediated by FceRI. Additionally, the association of Lyn with these gangliosides is much stronger than the association of Lyn with FceRI. These data suggest that a complex of molecules that includes the gangliosides, FceRI, and Lyn is essential for initiation of signal transduction in MCs (Minoguchi et al., 1994; Swaim et al., 1994).

Furthermore, the cross-linking of gangliosides derived from GD1b by mAb AA4 or its $\mathrm{F}\left(\mathrm{ab}^{\prime}\right)_{2}$ results in a partial activation of RBL-2H3 MCs. The morphological changes and intracellular signaling response was similar to that observed following FceRI activation, however, in less pronounced. mAb AA4 binding induces phosphorylation of FceRI $\beta$ and $\gamma$ chains, activation of PLC $\gamma 1$, Lyn and Syk, PIP 2 hydrolysis, increases $\left[\mathrm{Ca}^{2+}\right]_{\mathrm{i}}$, PKC redistribution as well as cell spreading and ruffling, but does not induce degranulation (Oliver et al., 1992; Stephan et al., 1997; Swaim et al., 1994). Although cross-linking GD1b derived gangliosides clearly activates MCs and consequently modulates some intracellular signaling pathways, whether or not cross-linking these gangliosides stimulates release of the other class of MC mediators, the newly formed and newly synthesized mediators, had not been previously investigated. The results presented here in Research Articles Chapter I showed that crosslinking MC specific gangliosides derived from GD1b with mAbAA4 released the newly formed lipid mediators, prostaglandins D2 and E2, without release of leukotrienes B4 and C4. Additionally, cross-linking GD1b derived gangliosides also resulted in the release of the newly synthesized mediators, interleukin-4, interleukin- 6 and TNF- $\alpha$.

\subsubsection{Proteomic profile of lipid rafts}

Membranes comprise a large proportion of the cellular biomass and 25-40\% of eukaryotic cellular proteins are membrane associated. Portions of these proteins specifically resides in or are transiently associated with lipid rafts. Therefore, investigating the protein composition of lipid rafts is crucial to understanding the biological events and identifying molecular pathways that are coordinated by these membrane microdomains. Mass-spectrometry based proteomics are a valuable tool to profile raft associated proteins (Inder et al., 2013; Minogue and Waugh, 2012; 
Mohamed et al., 2018; Mohamed et al., 2019). An analysis of lymphocyte activation and the resulting signaling events has dominated lipid raft proteomic studies and has demonstrated extensive changes in lipid raft protein composition and elucidated cellular interactomes (Bini et al., 2003; Gupta et al., 2006; Lin et al., 2010; Wollscheid et al., 2004). Moreover, proteomic analysis of lipid rafts has provided further insights into the functions of previously undescribed proteins in diverse cellular process. In addition to lymphocytes, proteomic strategies have been used to characterize lipid rafts from a variety of other tissue and cell types, including rat brain (Jia et al., 2006), HeLa cells (Liu et al., 2018), and immune cells such as neutrophils (Feuk-Lagerstedt et al., 2007; Nebl et al., 2002), monocytes (Zhang et al., 2008), macrophages (Dhungana et al., 2009), and natural killer cells (Man et al., 2005). However, in spite of approximately one hundred previous lipid raft proteome studies, no lipid raft proteomic data was available from MCs. The results on the proteome from MC lipid rafts presented in Research Articles Chapter II show that using two different post-isolation treatment methods, a total of 949 lipid raft associated proteins were identified. The majority of these MC lipid raft proteins had been already described in the RaftProtV2 database and are among highest cited/experimentally validated lipid raft proteins. Additionally, more than half of the identified proteins had lipid modifications and/or transmembrane domains. Classification of identified proteins into functional categories showed that the proteins were associated with cellular membrane compartments, and with some biological and molecular functions, such as regulation, localization, binding, catalytic activity and response to stimulus.

\subsection{SCAFFOLD PROTEIN RACK1 (RECEPTOR FOR ACTIVATED C KINASE 1)}

The scaffold protein RACK1 (receptor for activated C kinase 1) was identified, for the first time, in lipid rafts of RBL-2H3 MCs as part of the previous study on MC lipid rafts (FreitasFilho et al., 2019). RACK1 has been described in lipid rafts of other cells, such as lung adenocarcinoma cells (Sutton et al., 2013), dorsomedial striatum neurons (Phamluong et al., 2017) and T-cells (Ballek et al., 2016) where it has an import role in regulating the localization and function of diverse proteins and receptors at the plasma membrane . Therefore, RACK1 could be an important intracellular adaptor in lipid raft signaling events.

RACK1 is a member of the tryptophan-aspartate repeat (WD-repeat) family of proteins and highly conserved throughout evolution and is found in a wide range of eukaryotic phylum from Chlorophyta to Chordata (Rollins et al., 2019; Tarnowski et al., 2014). RACK1 is expressed in all mammalian tissues and is high in brain, thymus, liver, and spleen (Wang et al., 2003). RACK1 was originally cloned from a chicken liver cDNA library and a human B- 
lymphoblastoid cell line (B-LCL) (Guillemot et al., 1989). Ron et al. (1994) then identified RACK1 as an anchoring protein for Ser/Thr kinase PKCs, mainly the PKC $\beta I$ isoform, in the presence of its activators (phosphatidylserine, DAG and $\mathrm{Ca}^{2+}$ ). The protein was named RACK1

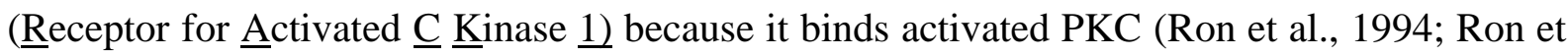
al., 1995). RACK1 is a 317 amino acid protein which has seven 40 amino acid repeats, which are defined by sequences flanked by GH and WD dipeptides. These WD-domains adopt a seven-bladed $\beta$-propeller structure. Each blade comprises a four-stranded antiparallel $\beta$-sheet (strand A-D), with strand A positioned near the central channel of the protein. The full WD repeat is not equivalent to a single blade but spans the A-B-C strands of one blade and the fourth of the previous one. The blades are joined by loops linking strand D of one blade to strand $\mathrm{A}$ of the next blade, which, together with the B-C loop, are exposed on the top face of the propeller. The other loops (loops A-B and C-D) are located on the opposite side. Loop D-A between blades 6 and 7 has a flexible knob-like structure (Figure 5A) (Adams et al., 2011; Rollins et al., 2019; Tarnowski et al., 2014). 
A
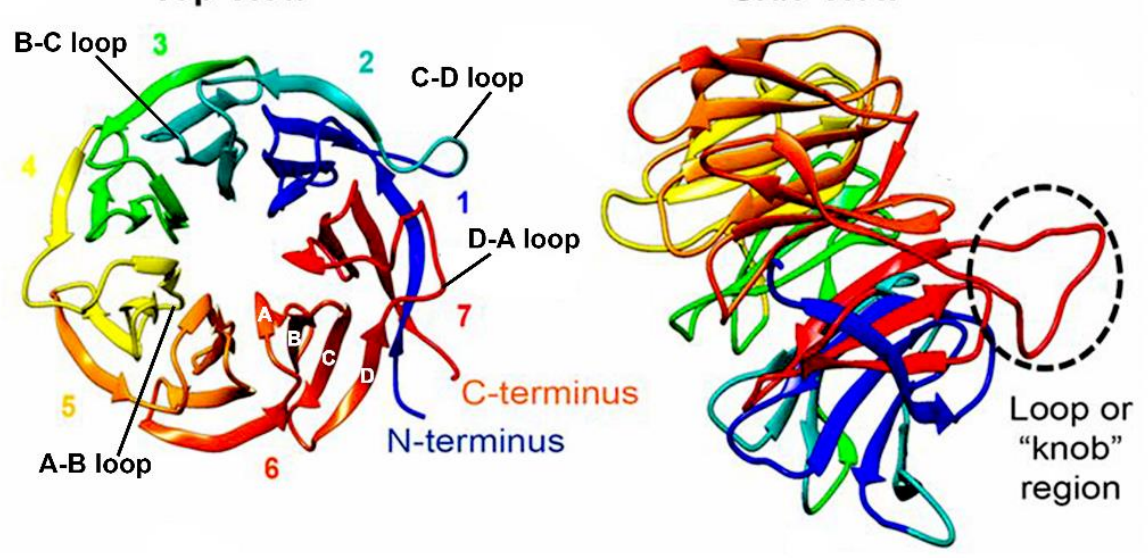

B
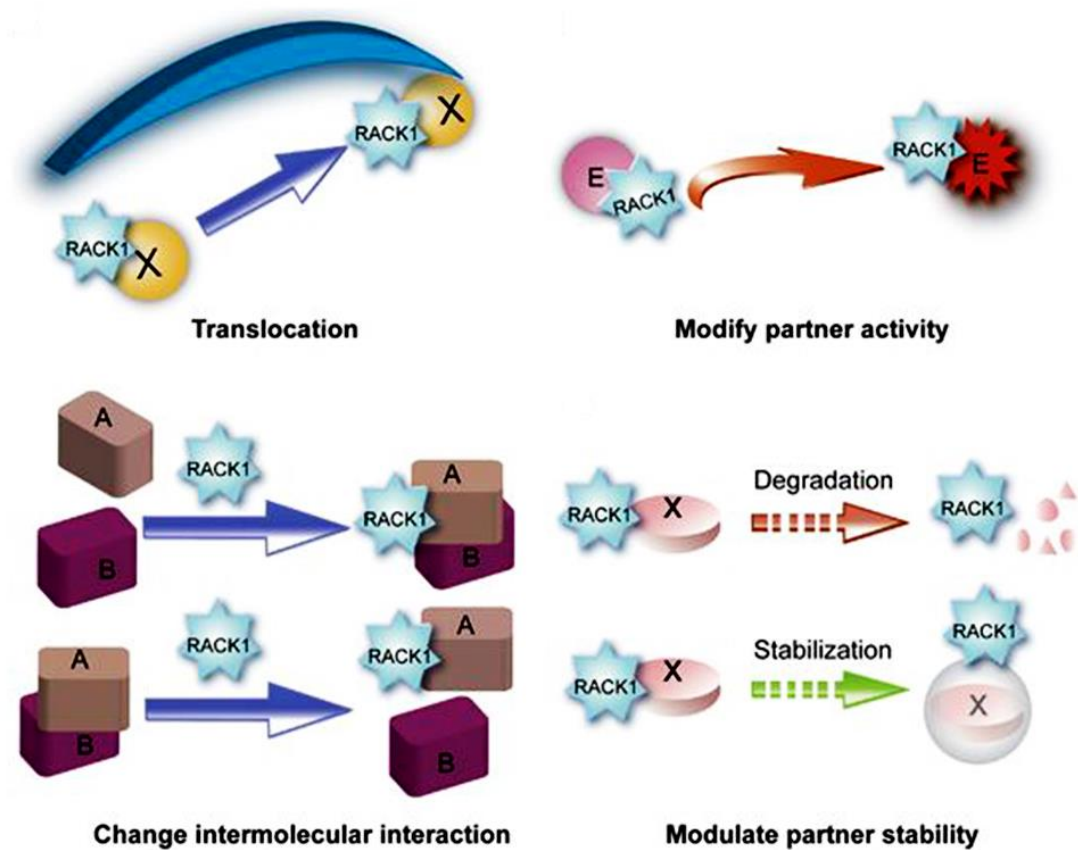

Modulate partner stability

Figure 5. RACK1 structure and RACK1 effects on its binding partners. (A) Top and side views of the structure of RACK1 (human RACK1; PDB: 4AOW) with the $\beta$-propeller regions color-coded (Adapted from Rollins et al., 2019). (B) RACK1 can shuttle binding partners (X) from one site to another (translocation); RACK1 could modify the activity of the partners, such as enzymes (E); RACK1 is able to change intermolecular interactions, enhancing association or dissociation of the molecules; RACK1 can modulate the stability of binding proteins, stabilizing them or promoting their degradation (Modified from Li \& Xie, 2015).

RACK1 lacks any enzymatic activity and its structural conformation provides multiple protein binding sites. RACK1 acts as a scaffold protein often with multiple and competing partners. Recently, the number of RACK1 binding proteins has increased exponentially and more than eighty proteins that interact with RACK1 directly or as part of larger complex have been described (Adams et al., 2011; Ron et al., 2013). RACK1 can associates with its partners in a constitutive, transient or stimulus-dependent manner. The effect of RACK1 binding can be 
classified into four types: shuttling binding partners from one site to another; modifying the activity of the partners; changing intermolecular interaction (enhancing association or dissociation); and modulating the stability of binding proteins (Figure 5B) (Li and Xie, 2015).

RACK1 acts as hub for signaling pathways and is involved in diverse cellular events that can occur from the plasma membrane to the nucleus of cells. RACK1 has proven to be a scaffold protein through interaction with a myriad of signaling proteins ranging from membrane receptors, G proteins, ion channels, $\mathrm{IP}_{3} \mathrm{R}$, kinases, especially SFKs, PKCs and MAP Kinases, phosphatases, phosphodiesterases, Rho GTPases, proteins that regulate cytoskeleton organization, and with structural proteins ribosome (by loop or 'knob' region; Figure 5A) (Dave et al., 2013; Jia et al., 2013; Kiely et al., 2006; Neasta et al., 2012; O'Donovan et al., 2007; Ron et al., 1995; Serrels et al., 2011; Wang et al., 2011; Woodard et al., 2010). RACK1 organizes these binding proteins into linear and branching signaling networks. RACK1 is thus involved in many cellular processes such as development, growth, survival, apoptosis, autophagy, translation, trafficking, morphology, adhesion and migration (Adams et al., 2011; Cox et al., 2003; Dave et al., 2013; Duff and Long, 2017; Jia et al., 2015; Kadrmas et al., 2007; Rollins et al., 2019; Ron et al., 2013; Zhao et al., 2015). It is essential that RACK1 expression be tightly regulated as any slight shift from the optimum expression level can have dramatic consequences for the organism. Deletion of the RACK1 orthologue in Saccharomyces cerevisiae, Asc1p, is not lethal but leads to a shift towards a hypoxic metabolism (Valerius et al., 2007). In contrast, depletion of RACK1 in pluricellular organisms is lethal. Fruit flies depleted of RACK1 never develop into adults (Kadrmas et al., 2007) and the global deletion of the RACK1 gene in mice is lethal at the gastrulation stage (Volta et al., 2013). Changes in RACK1 expression has also been associated with diverse pathological states such as, brain disorders, ischemia/reperfusion injury, heart and renal failure, muscle atrophy, tumor development and metastases, immunosenescence, and asthma (Adams et al., 2011; Calura et al., 2008; Duff and Long, 2017; Jia et al., 2015; Padanilam, 2001; Pass et al., 2001; Zakrzewicz et al., 2007; Zhao et al., 2015). Moreover, RACK1 can be a molecular target for virus and bacteria (Bi et al., 2018; Gallina et al., 2001; Smith et al., 2000; Ullah et al., 2019).

The role for RACK1 in the immune system has been investigated (Ron et al., 2013). Studies have indicated that the age-related decrease in RACK1 expression underlies the failure of the signal transduction cascade in immunosenescence (Corsini et al., 1999; Corsini et al., 2014; Corsini et al., 2009; Corsini et al., 2005). Modifications in the expression of RACK1 are also responsible for abnormal release of a range of inflammatory mediators by immune cells such as leukocytes, macrophages and dendritic cells (Corsini et al., 2015; Corsini et al., 2014; 
Yao et al., 2014). Additionally, a protein-protein interaction network analysis suggested that the gene gnb2l1 (guanine nucleotide-binding protein subunit beta-2-like 1), which encodes RACK1, appears to be involved in the asthma network (Hwang et al., 2008). Confirming this observation, in an allergic airway inflammatory model, RACK1 levels are increased in the lungs of ovalbumin (OVA)-induced mice (Pu et al., 2018). In asthmatic human patients, an aberrant $\mathrm{Ca}^{2+}$ influx, which can be correlated to a high level of RACK1, compromises the function of T regulatory cells (TReg) (Negoro et al., 2014). It is well established that MCs play a critical role in asthma (Bradding and Arthur, 2016; Pejler, 2019; Reuter et al., 2010) and that RACK1 acts as an important hub in signal transduction in immune cells. However, the functional role of RACK1 in MCs has not been previously investigated. The results on the role of RACK1 in MCs presented in Research Articles Chapter III demonstrates that RACK1 has previously undescribed roles in actin cytoskeleton dynamics as well as in calcium signaling and inflammatory mediator release.

In summary, MC activation can be induced by a variety of stimuli. However, the precise regulatory components and molecular mechanisms underlying differential mediator release in response to stimuli are not completely understood. Further knowledge of these processes may help to explain the broad spectrum of MC functions and indicate possible therapeutic targets for diseases in which MCs are involved. Therefore, this study aimed to: (I) characterize the role of MC specific gangliosides in differential mediator release; (II) describe and perform a functional analysis of the proteome profile of MC lipid rafts; and (III) determine the functional role of the scaffold protein RACK1 in MCs. 
AIMS 


\section{AIMS}

I) To examine the signal transduction and consequent release of newly formed lipid mediators and newly synthesized mediators following cross-linking of mast cell specific gangliosides derived from GD1b;

II) To investigate the qualitative proteomic profile and perform a functional analysis of lipid rafts from MCs;

III) To characterize the functional role of the scaffold protein RACK1 in actin dynamics and calcium signaling as related to mediator release in MCs. 
RESEARCH ARTICLES 


\section{RESEARCH ARTICLES}

\subsection{CHAPTER I}

Title: Cross-linking mast cell specific gangliosides stimulates the release of newly formed lipid mediators and newly synthesized cytokines

Authors: Edismauro Garcia Freitas Filho, Elaine Zayas Marcelino da Silva, Camila Ziliotto Zanotto, Constance Oliver, and Maria Célia Jamur

Journal: Mediators of inflammation (2016). Vol. 2016, Article ID 9160540, 10 pages, 2016. DOI: 10.1155/2016/9160540. Impact Factor: 3.57. 


\title{
Cross-Linking Mast Cell Specific Gangliosides Stimulates the Release of Newly Formed Lipid Mediators and Newly Synthesized Cytokines
}

\author{
Edismauro Garcia Freitas Filho, ${ }^{1}$ Elaine Zayas Marcelino da Silva, ${ }^{1}$ \\ Camila Ziliotto Zanotto, ${ }^{2}$ Constance Oliver, ${ }^{1}$ and Maria Célia Jamur ${ }^{1}$ \\ ${ }^{1}$ Department of Cell and Molecular Biology and Pathogenic Bioagents, Ribeirão Preto Medical School, University of São Paulo, \\ Avenida Bandeirantes 3900, 14049-900 Ribeirão Preto, SP, Brazil \\ ${ }^{2}$ Department of Pharmacology, Ribeirão Preto Medical School, University of São Paulo, Avenida Bandeirantes 3900, \\ 14049-900 Ribeirão Preto, SP, Brazil
}

Correspondence should be addressed to Maria Célia Jamur; mjamur@fmrp.usp.br

Received 25 April 2016; Accepted 13 July 2016

Academic Editor: Dianne Cooper

Copyright (C) 2016 Edismauro Garcia Freitas Filho et al. This is an open access article distributed under the Creative Commons Attribution License, which permits unrestricted use, distribution, and reproduction in any medium, provided the original work is properly cited.

\begin{abstract}
Mast cells are immunoregulatory cells that participate in inflammatory processes. Cross-linking mast cell specific GD1b derived gangliosides by mAbAA4 results in partial activation of mast cells without the release of preformed mediators. The present study examines the release of newly formed and newly synthesized mediators following ganglioside cross-linking. Cross-linking the gangliosides with mAbAA4 released the newly formed lipid mediators, prostaglandins $\mathrm{D}_{2}$ and $\mathrm{E}_{2}$, without release of leukotrienes $\mathrm{B}_{4}$ and $\mathrm{C}_{4}$. The effect of cross-linking these gangliosides on the activation of enzymes in the arachidonate cascade was then investigated. Ganglioside cross-linking resulted in phosphorylation of cytosolic phospholipase $\mathrm{A}_{2}$ and increased expression of cyclooxygenase2. Translocation of 5-lipoxygenase from the cytosol to the nucleus was not induced by ganglioside cross-linking. Cross-linking of GD1b derived gangliosides also resulted in the release of the newly synthesized mediators, interleukin-4, interleukin-6, and TNF$\alpha$. The effect of cross-linking the gangliosides on the MAP kinase pathway was then investigated. Cross-linking the gangliosides induced the phosphorylation of ERK1/2, JNK1/2, and p38 as well as activating both NFKB and NFAT in a Syk-dependent manner. Therefore, cross-linking the mast cell specific GDlb derived gangliosides results in the activation of signaling pathways that culminate with the release of newly formed and newly synthesized mediators.
\end{abstract}

\section{Introduction}

Gangliosides are sialic acid containing glycosphingolipids that are present in the outer leaflet of the plasma membrane as well as in the membranes of some organelles $[1,2]$. Gangliosides play a role in diverse physiological processes including growth, differentiation, cell-cell interactions, and cell signaling. They are also involved in many pathological processes, acting as receptors for viruses and toxins, and are implicated in tumor progression, atherosclerosis, and neurodegenerative disorders [3].

Gangliosides are present on the surface of mast cells and are critical for mast cell function [1]. Mast cells are multifunctional immune cells that participate in various biological events, such as inflammation and allergy. Mast cell functions are directly related to their activation and subsequent release of biologically active mediators $[4,5]$. Mast cell activation via the high affinity $\operatorname{IgE}$ receptor (FcERI) is the best characterized form of activation. It occurs when multivalent antigens cross-link antigen-specific immunoglobulin $\mathrm{E}$ (IgE) bound to FceRI on the mast cell surface. Crosslinking FceRI initiates a signal transduction cascade that is dependent on the tyrosine kinase Syk [6]. This activation results in the release of three classes of mediators: preformed mediators such as histamine, proteases, cytokines, and enzymes; newly formed lipid mediators which are 
comprised of prostaglandins (PG), leukotrienes (LT), and platelet activating factor; and newly synthesized mediators which include cytokines and chemokines $[4,7,8]$.

Mast cell specific gangliosides derived from GD1b are present on the surface of rodent mast cells $[9,10]$. Crosslinking the GD1b derived gangliosides with a ganglioside specific monoclonal antibody (mAbAA4) or its $\mathrm{F}\left(\mathrm{ab}^{\prime}\right)_{2}$ fragment results in partial activation of RBL-2H3 mast cells without degranulation or release of preformed mediators [11, 12]. Although cross-linking GD1b derived gangliosides activates mast cells, whether or not cross-linking these gangliosides stimulates release of newly formed and newly synthesized mediators has not been investigated. Therefore, it was of interest to determine if newly formed lipid mediators and newly synthesized mediators were released following ganglioside cross-linking and whether or not this release was Sykdependent.

\section{Materials and Methods}

2.1. Cells. RBL-2H3 cells, a rat mast cell line [13], a Syknegative variant of RBL-2H3 cells (C4A2) [14], the stable $\mathrm{RBL}-2 \mathrm{H} 3$ cell lines expressing NF $\kappa \mathrm{B}-\mathrm{GFP}$ reporter $(\mathrm{NF} \kappa \mathrm{B} 2$; [15]); NFAT-GFP reporter (VB9; [16]); and Syk-negative cell lines expressing $\mathrm{NF} \kappa \mathrm{B}-\mathrm{GFP}$ reporter (IC2; [6]); and NFAT-GFP reporter (IH10; [16]) were generously provided by Dr. Reuben P. Siraganian (National Institute of Dental and Craniofacial Research, National Institutes of Health, Bethesda, MD). Cells were grown as monolayers at $37^{\circ} \mathrm{C}$ in Dulbecco's modified Eagle's medium (DMEM) supplemented with $15 \%$ fetal calf serum, $0.434 \mathrm{mg} / \mathrm{mL}$ glutamine, and an antibiotic-antimycotic mixture containing $100 \mathrm{U} / \mathrm{mL}$ penicillin, $100 \mu \mathrm{g} / \mathrm{mL}$ streptomycin, and $0.25 \mu \mathrm{g} / \mathrm{mL}$ amphotericin B (all from Life Technologies, Gibco, Carlsbad, CA) in a humidified incubator with $5 \% \mathrm{CO}_{2}$ in air. Transfected cells were selected with Geneticin $(0.4 \mathrm{mg} / \mathrm{mL})$ (Sigma-Aldrich; St. Louis, MO).

2.2. Antibodies. Mouse monoclonal antibody anti-rat GD1b derived gangliosides (mAbAA4) were purchased from BD Biosciences (San Jose, CA). Rabbit polyclonal antibody anti-human phospho-cPLA ${ }_{2}$; rabbit polyclonal antibody anti-human $\mathrm{CPLA}_{2}$; rabbit $\mathrm{mAb}$ anti-human phosphoERK1/2; rabbit $m A b$ anti-rat ERK1/2; rabbit $m A b$ anti-human phospho-JNK1/2; rabbit polyclonal antibody anti-human JNK1/2; rabbit mAb anti-human phospho-p38; rabbit polyclonal antibody anti-human anti-p38, and rabbit polyclonal antibody anti-human $\alpha / \beta$-tubulin were purchased from Cell Signaling Technology Inc. (Danvers, MA). Rabbit polyclonal antibody anti-rat cyclooxygenase-2 (COX-2), rabbit $\mathrm{mAb}$ anti 5-lipoxygenase (5-LO), and rabbit polyclonal antibody anti-mouse Lamin B1 were purchased from Abcam (Cambridge, MA). Donkey anti-rabbit IgG conjugated to horseradish peroxidase (HRP) (Jackson ImmunoResearch Laboratories Inc., West Grove, PA) was used as the secondary antibody.

2.3. Mast Cell Activation and Mediator Release. In order to cross-link the GD1b derived gangliosides, RBL-2H3 cells and C4A2 cells were incubated with mAbAA4 at various concentrations $(1,2.5,5$, or $10 \mu \mathrm{g} / \mathrm{mL})$ depending on the experiment. For stimulation via FceRI, cells were sensitized overnight (ON) with mouse IgE anti-TNP ascites fluid (1:5,000 dilution) and then stimulated with $50 \mathrm{ng} / \mathrm{mL}$ of $\mathrm{DNP}_{48}$-HSA (Sigma-Aldrich) for $30 \mathrm{~min}$ or for $1 \mathrm{~h}$ and then rinsed and cultured for an additional $3 \mathrm{~h}$, for the release of newly formed lipid mediators $\left(\mathrm{PGD}_{2}, \mathrm{PGE}_{2}, \mathrm{LTB}_{4}\right.$, and $\left.\mathrm{LTC}_{4}\right)$. In order to examine the release of newly synthesized mediators (IL-4, IL-6, and TNF- $\alpha$ ), cells were stimulated for $1 \mathrm{~h}$, rinsed, and cultured for an additional $11 \mathrm{~h}$. For FceRI independent stimulation, cells were incubated with $0.1 \mu \mathrm{g} / \mathrm{mL}$ of calcium ionophore A23187 (Sigma-Aldrich). $\mathrm{PGD}_{2}, \mathrm{PGE}_{2}$, $\mathrm{LTB}_{4}$, and $\mathrm{LTC}_{4}$ in culture supernatants were analyzed using EIA kits (Cayman Chemical, Ann Arbor, MI). IL-4, IL-6, and TNF- $\alpha$ in the culture supernatants were measured using ELISA kits (BD Biosciences) according to the manufacturer's instructions. Nonstimulated cells were used as controls.

2.4. NFKB and NFAT Activation. NFkB2 cells, VB9 cells, IC2 cells, and IH10 cells were incubated with mAbAA4, stimulated via FceRI, or with calcium ionophore for $1 \mathrm{~h}$ (as described in Section 2.3), rinsed, and cultured for an additional $5 \mathrm{~h}(\mathrm{NF} \kappa \mathrm{B}$ activation) or $15 \mathrm{~h}$ (NFAT activation). Cells were analyzed by flow cytometry and the percent of GFP positive cells was determined using a Guava Easy Cyte Mini System and Cytosoft Blue software (Guava Technologies Inc., Hayward, CA).

2.5. Immunoblotting. Total cells lysates were obtained as previously described [17]. For some experiments, nuclear and cytosolic extracts were obtained as previously described [18]. The proteins were separated electrophoretically on $8 \%$ or $12 \%$ polyacrylamide gels and transferred to Hybond membranes (GE Healthcare Life Sciences, Marlborough, MA). After transfer, the membranes were blocked for $1 \mathrm{~h}$ at RT in TTBS

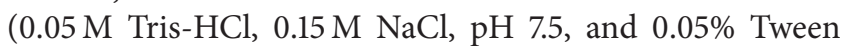
20) containing $4 \%$ BSA (Sigma-Aldrich). After blocking, the membranes were incubated $\mathrm{ON}$ at $4^{\circ} \mathrm{C}$ with the primary antibodies diluted in TTBS. The membranes were then washed, incubated for $30 \mathrm{~min}$ with secondary antibody, and developed using enhanced chemiluminescence (ECL Kit; GE Healthcare). The images were obtained with ImageQuant LAS 4000 (GE Healthcare). Mean optical density of the target protein was determined using ImageJ software (NIH).

2.6. Statistical Analyses. Results were analyzed using GraphPad Prism (GraphPad Software, Inc., San Diego, CA). The results were expressed as mean $\pm \mathrm{SD}$ and differences between experimental samples were assessed by one-way analysis of variance (ANOVA) with Bonferroni's post hoc test; $P<0.05$ was considered statistical significant.

\section{Results}

3.1. Cross-Linking GD1b Derived Gangliosides with $\mathrm{mAbAA4}$ Induced the Release of Newly Formed Lipid Mediators $P_{G}$ and $P G E_{2}$. RBL-2H3 cells and C4A2 Syk-negative cells 


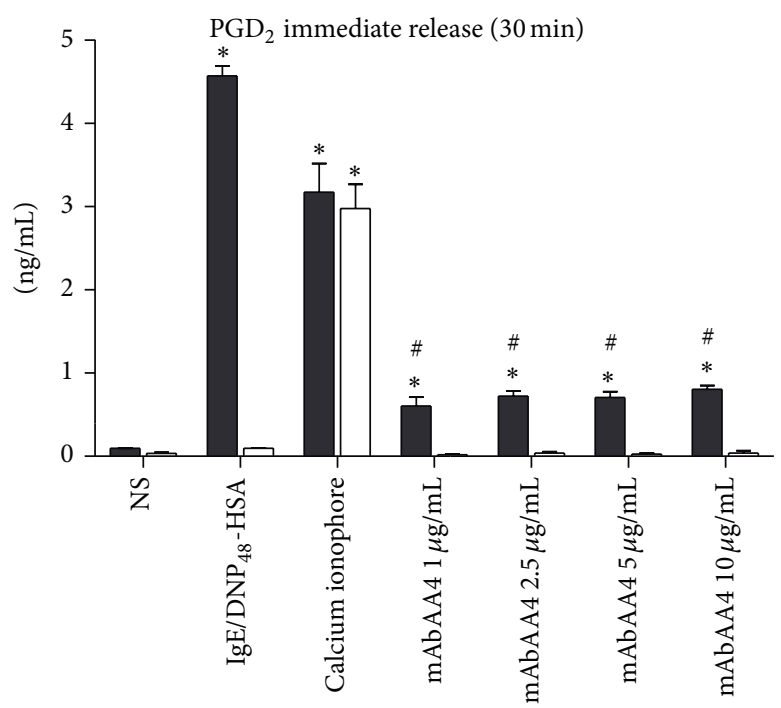

RBL-2H3 cells C4A2 cells

(a)

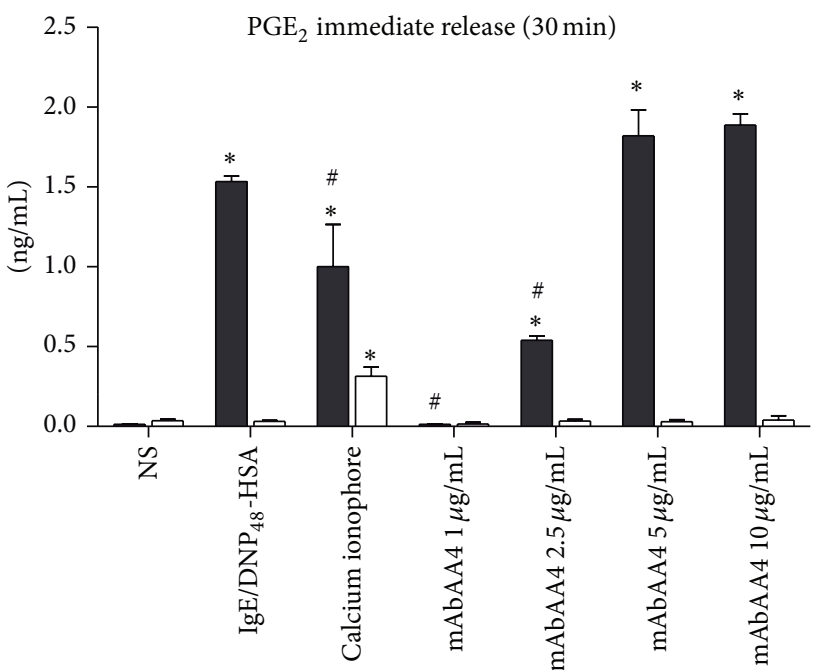

RBL-2H3 cells C4A2 cells

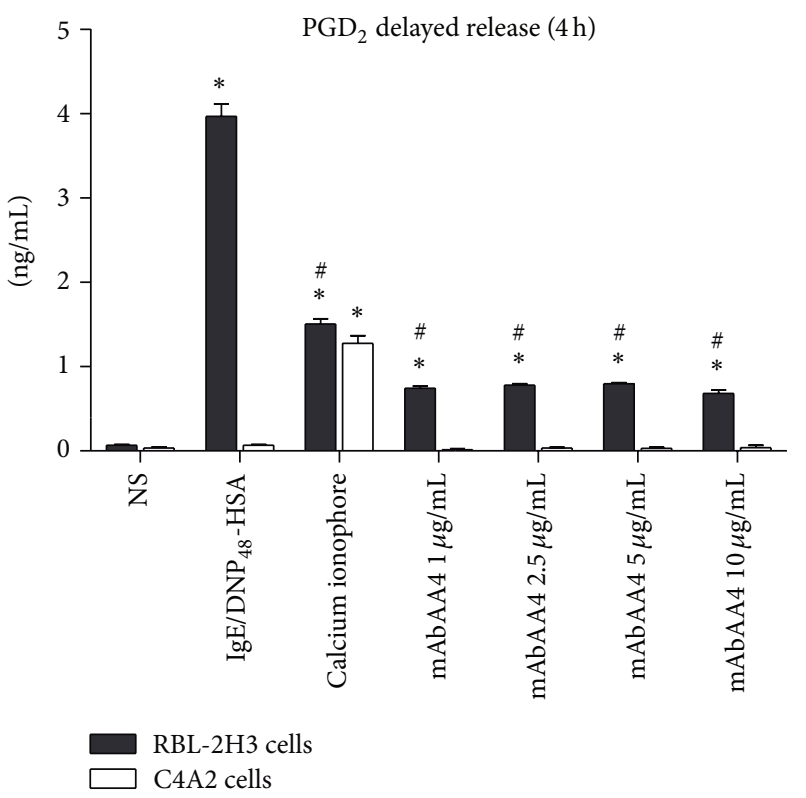

(b)

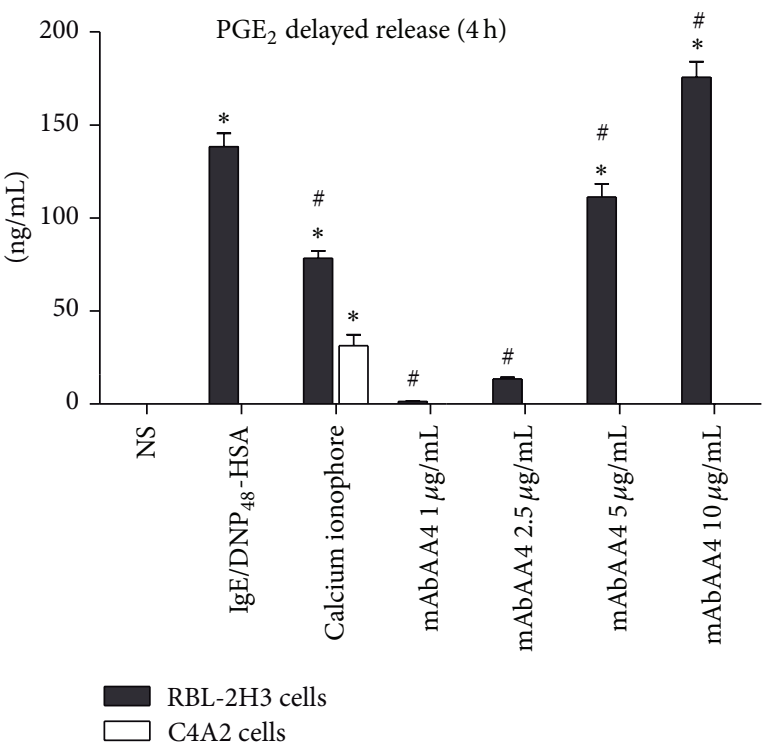

(d)

FIGURE 1: Cross-linking GD1b derived gangliosides by mAbAA4 induced Syk-dependent release of $\mathrm{PGD}_{2}$ and $\mathrm{PGE}_{2}$. For stimulation via FceRI, RBL-2H3 cells and C4A2 Syk-negative cells were sensitized with IgE anti-TNP and stimulated with DNP $48-\mathrm{HSA}(50 \mathrm{ng} / \mathrm{mL})$. For FceRI independent stimulation, the cells were incubated with calcium ionophore $(0.1 \mu \mathrm{g} / \mathrm{mL})$. To cross-link GD1b derived gangliosides, cells were incubated with mAbAA4 $(1,2.5,5$, and $10 \mu \mathrm{g} / \mathrm{mL})$. Nonstimulated (NS) cells were used as negative controls. Culture supernatants were collected after $30 \mathrm{~min}$ of incubation to evaluate immediate release (a and c) or cells were incubated for $1 \mathrm{~h}$ and rinsed and cultured for an additional $3 \mathrm{~h}$ and culture supernatants were collected to evaluate delayed release (b and d). $\mathrm{PGD}_{2}\left(\mathrm{a}\right.$ and $\mathrm{b}$ ) and $\mathrm{PGE}_{2}(\mathrm{c}$ and $\mathrm{d}$ ) were measured in the culture supernatant by EIA. Data is expressed as the mean \pm SD of three independent experiments. ${ }^{*} P<0.05$ between experimental samples and the nonstimulated (NS) cells. ${ }^{\#} P<0.05$ between experimental samples and FceRI stimulated RBL-2H3 cells.

were incubated with mAbAA4 for either $30 \mathrm{~min}$ or $1 \mathrm{~h}$ and then rinsed and cultured for an additional $3 \mathrm{~h}$ to evaluate both immediate and delayed release of lipid mediators. The cross-linking of GDib derived gangliosides by mAbAA4 induced both immediate and delayed release of $\mathrm{PGD}_{2}$ (Figures $1(\mathrm{a})$ and $1(\mathrm{~b})$ ) and $\mathrm{PGE}_{2}$ (Figures $1(\mathrm{c})$ and $1(\mathrm{~d})$ ) by RBL-2H3 cells, but not by Syk-negative C4A2 cells (Figures 1(a)-1(d)). Furthermore, the amount of $\mathrm{PGE}_{2}$ released following ganglioside cross-linking was higher when compared to that found after FceRI stimulation. Interestingly, cross-linking GD1b derived gangliosides did not induce the release of the LT, $\mathrm{LTB}_{4}$, and $\mathrm{LTC}_{4}$ (see Supplementary Figures $1(\mathrm{~A})$ and $1(\mathrm{~B})$ in Supplementary Material available online at http://dx.doi.org/10.1155/2016/9160540). 


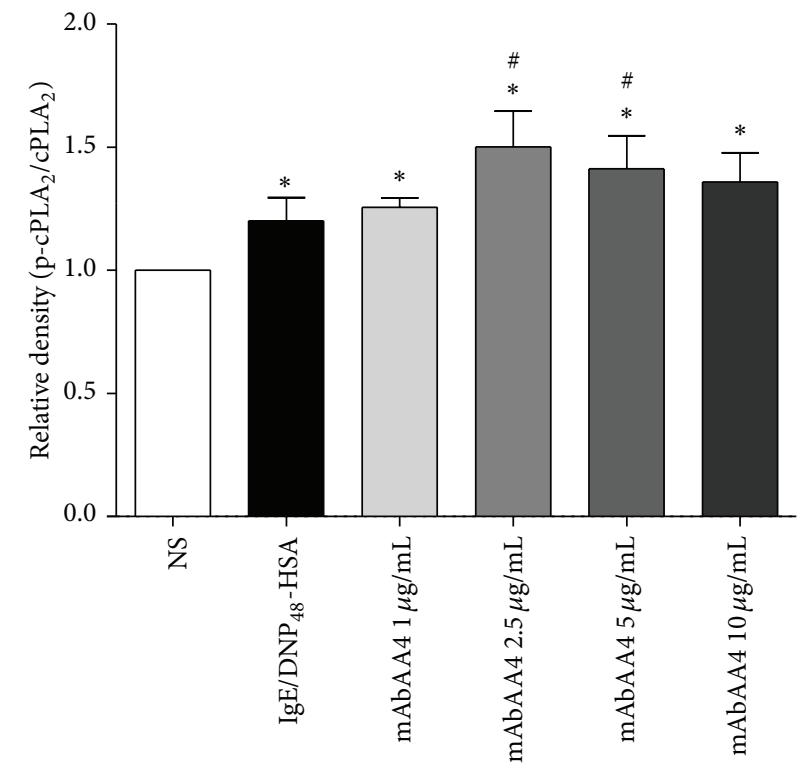

(a)

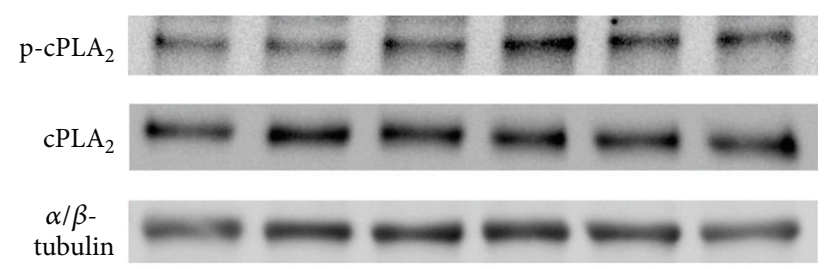

(b)

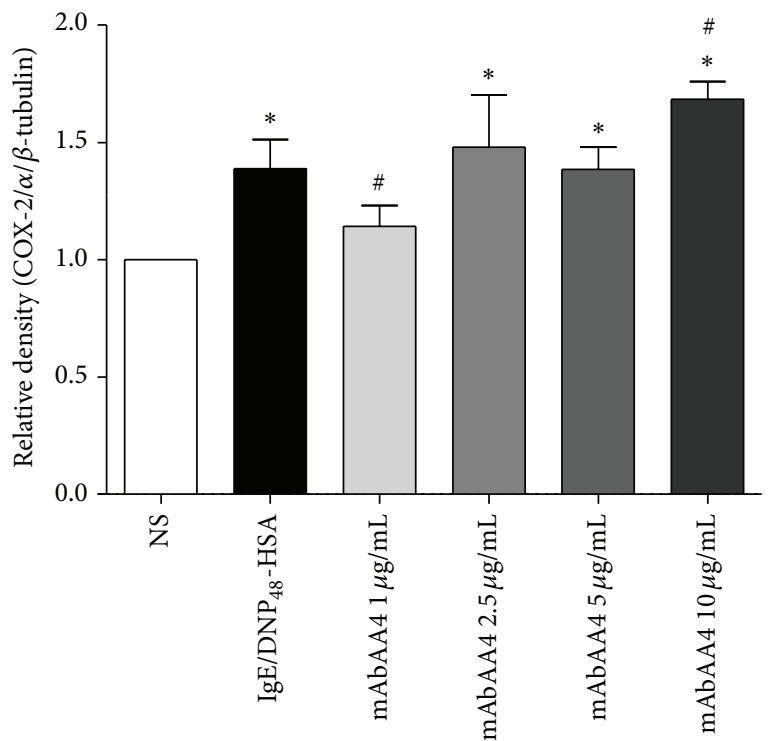

(c)

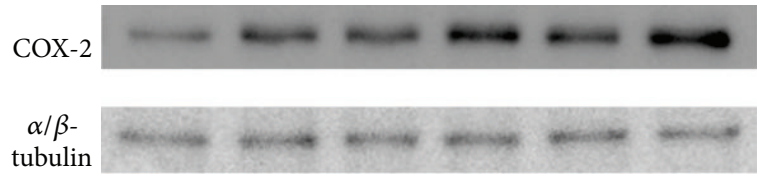

(d)

FIGURE 2: Cross-linking GD1b derived gangliosides by mAbAA4 increased cPLA 2 phosphorylation and induced COX-2 expression. Either RBL-2H3 mast cells were stimulated via FceRI, by sensitizing the cells with IgE anti-TNP and stimulating with $\mathrm{DNP}_{48}-\mathrm{HSA}(50 \mathrm{ng} / \mathrm{mL})$, or cells were incubated with mAbAA4 $(1,2.5,5$, and $10 \mu \mathrm{g} / \mathrm{mL})$ for $5 \mathrm{~min}\left(\mathrm{cPLA}_{2}\right.$ phosphorylation) or for $1 \mathrm{~h}$ and then rinsed and cultured for an additional $3 \mathrm{~h}$ (COX-2 expression). Total cell lysates were immunoblotted with antibodies against p-cPLA $\mathrm{A}_{2}, \mathrm{CPLA} \mathrm{A}_{2}, \mathrm{COX}-2$, and $\alpha / \beta$ tubulin (housekeeping protein) and the mean optical density of the bands was determined. Densitometry of the changes in expression and phosphorylation of proteins were corrected for $\alpha / \beta$-tubulin. Data were expressed as the fold of nonstimulated (NS) cells. (a) Ratio of phosphorylated $\mathrm{CPLA}_{2} /$ total cPLA $;$ (b) a representative blot from (a); (c) ratio of COX-2/ $\alpha / \beta$-tubulin; (d) a representative blot from (c). Data is expressed as the mean \pm SD of three independent experiments. ${ }^{*} P<0.05$ between experimental samples and the nonstimulated (NS) cells. ${ }^{\#} P<0.05$ between experimental samples and FceRI stimulated cells.

3.2. Cross-Linking GD1b Derived Gangliosides with mAbAA4 Resulted in Phosphorylation of Cytosolic Phospholipase $A_{2}$ $\left(\mathrm{PLA}_{2}\right)$ and Cyclooxygenase-2 (COX-2) Expression. Crosslinking GD1b derived gangliosides resulted in the release of PGs but not LTs. Therefore, $\mathrm{cPLA}_{2}$ phosphorylation and induction of COX-2 expression, which are required for PG generation, were investigated. An increase in $\mathrm{CPLA}_{2}$ phosphorylation was observed after incubation of RBL-2H3 cells with mAbAA4 for $5 \mathrm{~min}$ and the levels of $\mathrm{CPLA}_{2}$ phosphorylation were higher than those observed in cells stimulated via FceRI (Figures 2(a) and 2(b)). COX-2 expression was also induced in cells incubated with mAbAA4 for $1 \mathrm{~h}$ and rinsed and cultured for an additional $3 \mathrm{~h}$ (Figures 2 (c) and 2(d)). In contrast, translocation of 5-LO from the cytosol to the nucleus, a requirement for LT generation, was not induced by ganglioside cross-linking (Supplementary Figures $1(\mathrm{C})-1(\mathrm{~F})$ ). Therefore, the cross-linking of GD1b derived gangliosides specifically induces the activation of the arachidonic pathway responsible for PG generation in mast cells.
3.3. Cross-Linking GD1b Derived Gangliosides with mAbAA4 Induced the Release of Newly Synthesized Cytokines. Mast cell activation via FceRI leads to transcription factor activation resulting in the production and release of cytokines [19]. Therefore, it was of interest to investigate whether cytokines are released after cross-linking GD1b derived gangliosides by mAbAA4. RBL-2H3 cells and Syk-negative C4A2 cells were incubated with mAbAA4 for $1 \mathrm{~h}$ and rinsed and cultured for an additional $11 \mathrm{~h}$. Ganglioside cross-linking resulted in a Syk-dependent release of the newly synthesized mediators, interleukin-4 (IL-4) (Figure 3(a)), interleukin-6 (IL-6) (Figure 3(b)), and tumor necrosis factor- $\alpha$ (TNF- $\alpha$ ) (Figure 3(c)). Interestingly, the amount of cytokines released after ganglioside cross-linking, with the exception of IL-6, was lower than that observed after stimulation via FceRI.

3.3.1. Cross-Linking GD1b Derived Gangliosides with $m A b A A 4$ Induced MAP Kinase Phosphorylation. MAP kinases are involved in signaling pathways that lead to production of newly synthesized mediators [20]. Since incubation of mast 


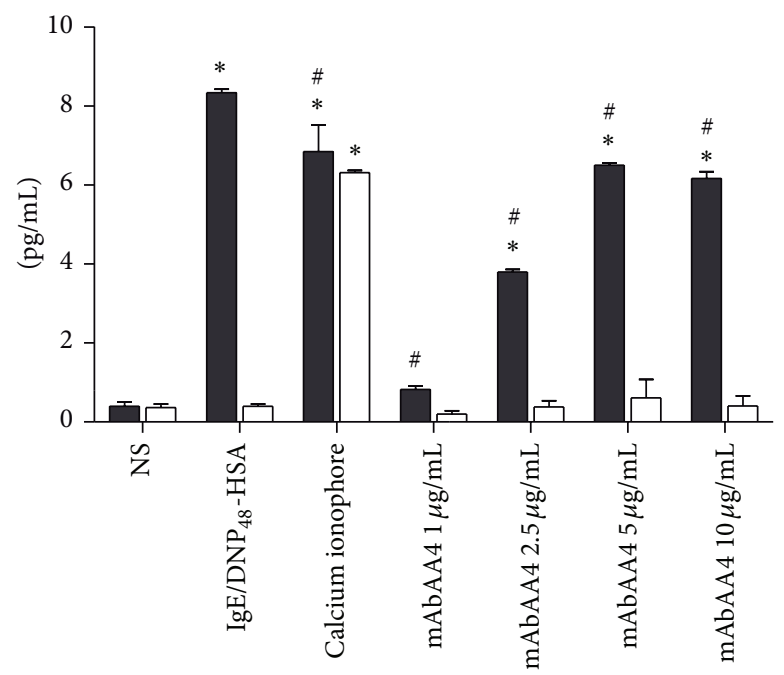

RBL-2H3 cells C4A2 cells

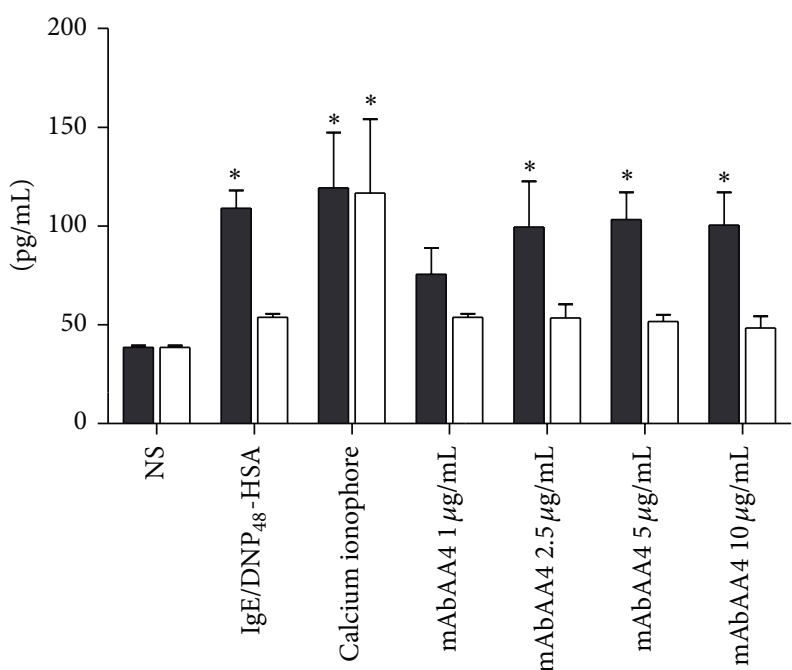

RBL-2H3 cells C4A2 cells

(a)

(b)

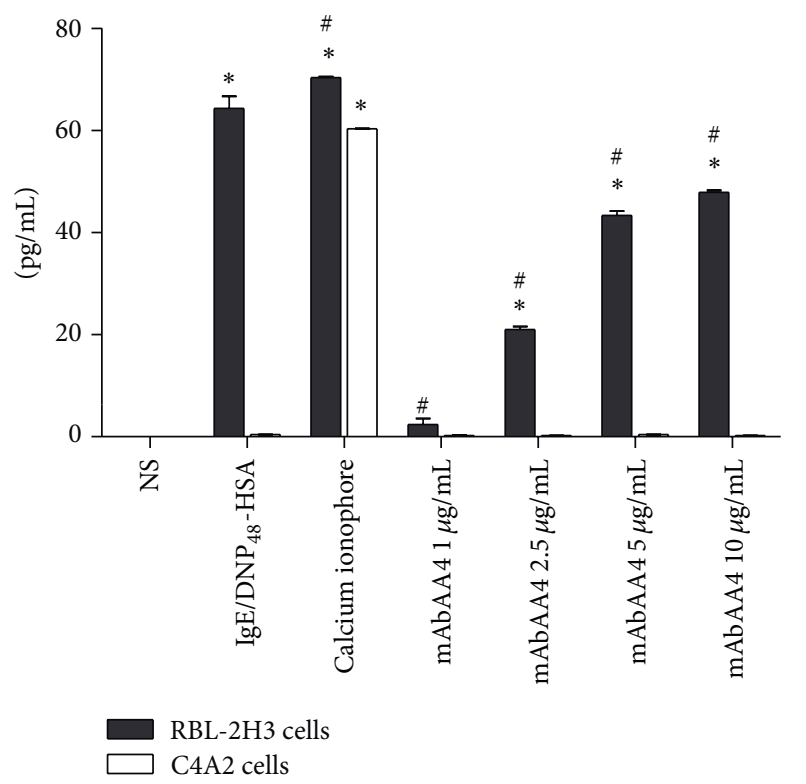

(c)

FIGURE 3: Cross-linking GD1b derived gangliosides with mAbAA4 induced the release of IL-4, IL-6, and TNF- $\alpha$ in a Syk-dependent manner. For stimulation via FceRI, RBL-2H3 cells and C4A2 Syk-negative cells were sensitized with IgE anti-TNP and stimulated with DNP $48-\mathrm{HSA}$ $(50 \mathrm{ng} / \mathrm{mL})$. For FceRI independent stimulation, the cells were incubated with calcium ionophore $(0.1 \mu \mathrm{g} / \mathrm{mL})$. To cross-link GD1b derived gangliosides, cells were incubated with mAbAA4 $(1,2.5,5$, and $10 \mu \mathrm{g} / \mathrm{mL})$. Nonstimulated (NS) cells were used as negative controls. Culture supernatants were collected $1 \mathrm{~h}$ after stimulation and the cells were rinsed and cultured for an additional $11 \mathrm{~h}$ to evaluate cytokine release. IL- 4 (a), IL-6 (b), and TNF- $\alpha$ (c) were measured in the culture supernatants by ELISA. Data is expressed as the mean \pm SD of three independent experiments. ${ }^{*} P<0.05$ between experimental samples and the nonstimulated (NS) cells. ${ }^{\#} P<0.05$ between experimental samples and FceRI stimulated RBL-2H3 cells.

cells with mAbAA4 resulted in the release of IL-4, IL-6, and TNF- $\alpha$, it was of interest to investigate the degree of MAP kinase phosphorylation induced by cross-linking the GDlb derived gangliosides. When RBL-2H3 cells were incubated with mAbAA4 for $10 \mathrm{~min}$, MAP kinases ERK1/2, JNK1/2, and p38 were phosphorylated (Figure 4). The degree of MAP kinase phosphorylation in mast cells incubated with
mAbAA4 was less than that observed in cells stimulated via FceRI, which agrees with the amount of cytokine released.

3.3.2. Cross-Linking GD1b Derived Gangliosides with mAbAA4 Induced the Activation of Transcription Factors. Transcription factor activation is the ultimate requirement for the production of newly synthesized mediators [21]. Therefore, 


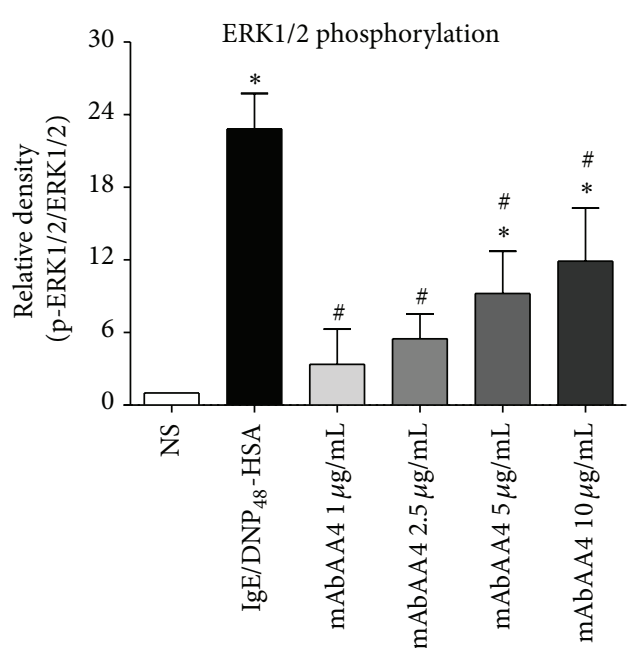

(a)

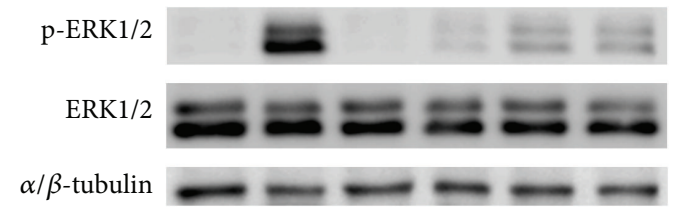

(b)

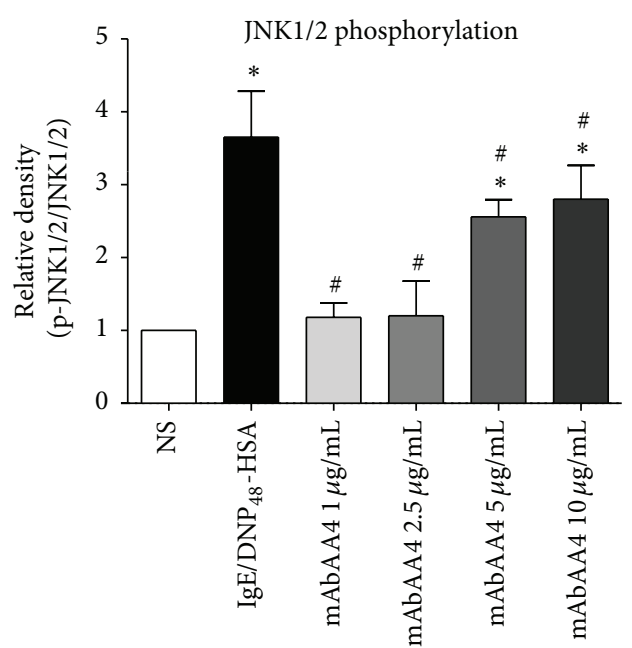

(c)

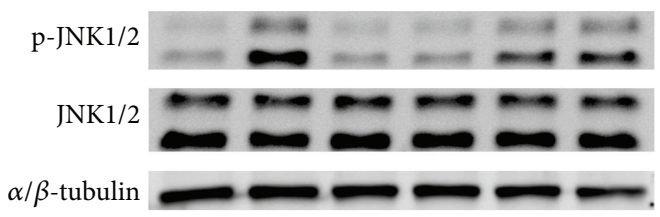

(d)

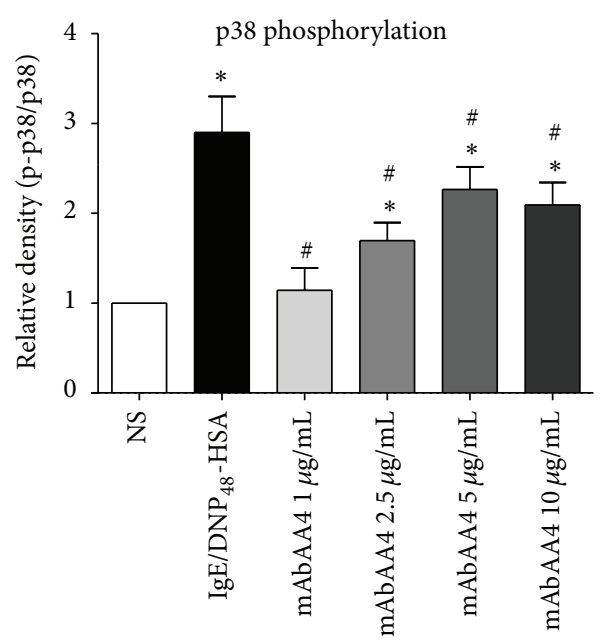

(e)

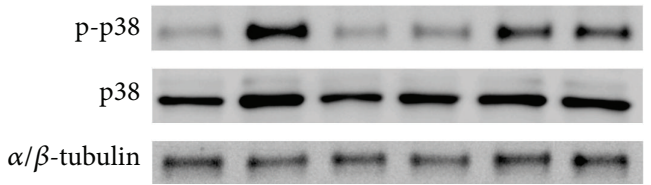

(f)

FIGURE 4: Cross-linking GD1b derived gangliosides with mAbAA4 induced MAP kinase phosphorylation in mast cells. RBL-2H3 cells were either stimulated via FceRI, where cells were sensitized with IgE anti-TNP and stimulated with $\mathrm{DNP}_{48}-\mathrm{HSA}(50 \mathrm{ng} / \mathrm{mL})$ or incubated with mAbAA4 $(1,2.5,5$, and $10 \mu \mathrm{g} / \mathrm{mL})$ for $10 \mathrm{~min}$. Total cell lysates were immunoblotted with antibodies against phospho-ERK1/2 (p-ERK1/2), ERK1/2, phospho-JNK1/2 (p-JNK1/2), JNK1/2, phospho-p38 (p-p38), p38, and $\alpha / \beta$-tubulin (housekeeping protein) and the mean optical density of the bands was determined. Densitometry of the changes in expression and phosphorylation of proteins were corrected for $\alpha / \beta$ tubulin. Data is expressed as the fold of nonstimulated (NS) cells. (a) Ratio of phosphorylated ERK1/2/total ERK1/2; (b) a representative blot from (a); (c) ratio of phosphorylated JNK1/2/total JNK1/2; (d) a representative blot from (c); (e) ratio of phosphorylated p38/total p38; (f) a representative blot from (e). Data is expressed as the mean $\pm \mathrm{SD}$ of three independent experiments. ${ }^{*} P<0.05$ between experimental samples and the nonstimulated (NS) cells. ${ }^{\#} P<0.05$ between experimental samples and FceRI stimulated cells. 


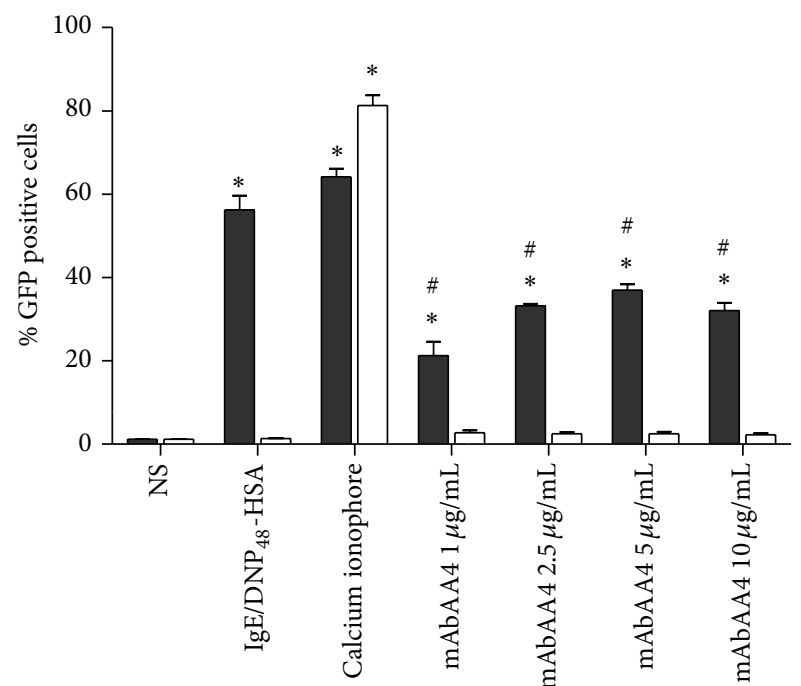

$\mathrm{NF} \kappa \mathrm{B} 2$ cells IC2 cells

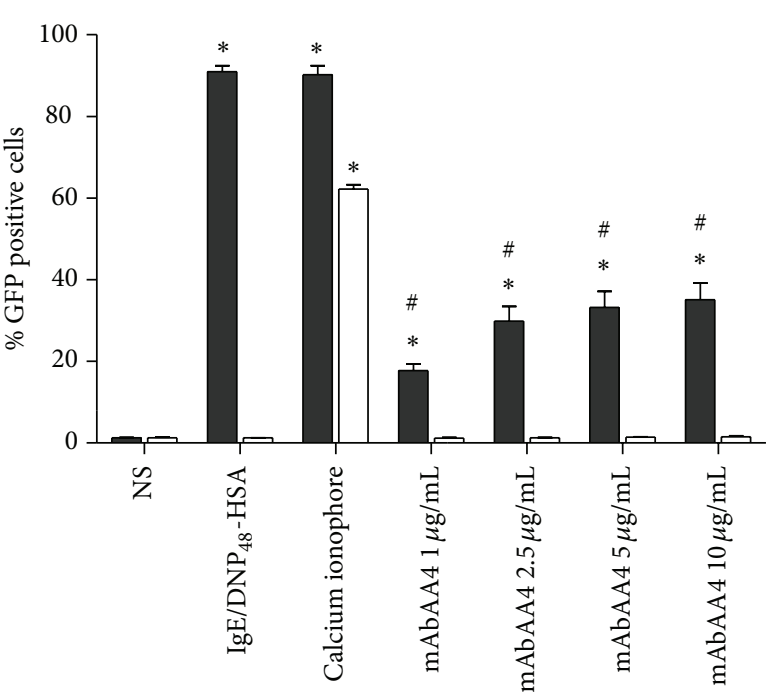

VB9 cells IH10 cells

(a)

(b)

FIGURE 5: Cross-linking GD1b derived gangliosides by mAbAA4 induced the activation of the transcription factors NF $\kappa$ B and NFAT. NF $\kappa$ B2 cells, VB9 cells, IC2 cells, and IH10 cells were sensitized with IgE anti-TNP and stimulated with $\mathrm{DNP}_{48}-\mathrm{HSA}(50 \mathrm{ng} / \mathrm{mL})$ for $1 \mathrm{~h}$ and rinsed and cultured for additional $5 \mathrm{~h}((\mathrm{a}) ; \mathrm{NF} \kappa \mathrm{B})$ or $15 \mathrm{~h}((\mathrm{~b}) ; \mathrm{NFAT})$. For FceRI independent stimulation, the cells were incubated with calcium ionophore $(0.1 \mu \mathrm{g} / \mathrm{mL})$. To cross-link GD1b derived gangliosides, cells were incubated with mAbAA4 $(1,2.5,5$, and $10 \mu \mathrm{g} / \mathrm{mL})$. GFP expression was analyzed by flow cytometry. Data is expressed as the mean $\pm \mathrm{SD}$ of three independent experiments. ${ }^{*} P<0.05$ between experimental samples and the nonstimulated (NS) cells. ${ }^{\#} P<0.05$ between experimental samples and FceRI stimulated cells.

RBL-2H3 derived GFP reporter cell lines were used to assess $\mathrm{NF} \kappa \mathrm{B}$ and NFAT activation. Cross-linking GD1b derived gangliosides by mAbAA4 induced activation of both NFKB (Figure 5(a)) and NFAT (Figure 5(b)) in a Syk-dependent manner. However, transcription factor activation by ganglioside cross-linking was less prominent than that observed by stimulation via $\mathrm{F} \varepsilon \mathrm{RI}$.

\section{Discussion}

The present study demonstrates that cross-linking the mast cell specific GD1b derived gangliosides induces the release of newly formed and newly synthesized mediators. Furthermore, this release is Syk-dependent. However, previous investigations have demonstrated that mast cell activation by cross-linking these gangliosides does not induce the release of preformed mediators [11, 12]. Moreover, other studies have shown that cross-linking gangliosides can also activate a variety of cell types [22-26]. Antibodies to gangliosides have been shown to activate PKC and increase proliferation in lymphocytes [27, 28], stimulate calcium influx in oligodendrocytes [29], and induce leukocyte degranulation [30]. The molecular mechanisms by which cross-linking gangliosides can activate cells are poorly understood.

Eicosanoids (prostaglandins, thromboxane, leukotrienes, and lipoxins) are the most important lipid mediators generated by mast cells [31]. The results of the present study show that cross-linking GD1b derived gangliosides induces release of prostaglandins, but not leukotrienes. Incubation with mAbAA4 stimulated $\mathrm{CPLA}_{2}$ phosphorylation and incubation with mAbAA4 for extended periods of time increased COX-2 expression. The first step in eicosanoid generation is $\mathrm{Ca}^{2+}$-dependent phosphorylation of $\mathrm{CPLA}_{2}$ through the MAP kinase pathway. Phosphorylated $\mathrm{CPLA}_{2}$ translocates to cellular membranes, principally to the nuclear envelope, where arachidonic acid (AA) is released from membrane phospholipids by the action of $\mathrm{CPLA}_{2}$. AA is then metabolized either by COX-2 or CYP2E1 to produce PGs such as $\mathrm{PGE}_{2}$ or by 5-LO to produce LTs in concert with 5-lipoxygenaseactivating protein (FLAP) on the nuclear envelope [32,33]. Previous studies have shown that the immediate phase of PG generation (5-30 $\mathrm{min}$ ) requires the action of constitutively expressed COX-1 and phosphorylation of $\mathrm{CPLA}_{2}$, while the delayed phase of PG generation (4-6h) depends on the induced expression of COX-2 [34]. In addition, cross-linking GD1b derived gangliosides did not induce 5-LO translocation from the cytosol to the nuclear membrane. These results agree with the findings that ganglioside cross-linking induces release of prostaglandins, but not leukotrienes, and indicate that ganglioside cross-linking selectively stimulates the eicosanoid biosynthetic pathway to induce PG generation.

Cross-linking GD1b derived gangliosides induces the release of the newly synthesized mediators IL-4, IL-6, and TNF- $\alpha$. In mast cells, newly synthesized mediator expression depends on the activation of signaling pathways that ultimately leads to transcription factor activation [21]. These events culminate with cytokine production and release and can occur even in the absence of mast cell degranulation [16]. A variety of studies investigating FceRI independent mast cell activation also revealed that release of proinflammatory 
mediators can occur in the absence of degranulation [3537]. The production of newly synthesized mast cell mediators following FceRI activation relies on MAP kinase signaling pathways as well as on the activation of the transcription factors NF $\kappa$ B and NFAT.

The MAP kinase signaling pathway participates in activation, differentiation, proliferation, and migration of mast cells. Cross-linking GD1b derived gangliosides results in ERK1/2, JNK1/2, and p38 MAP kinase phosphorylation. ERK1/2 is an essential signal in the production of the newly synthesized mediators IL-5, IL-3, IL-13, and TNF- $\alpha$ in mast cells [38]. JNK1/2 is responsible, at least partially, for the expression and production of several cytokines, including IL6 and TNF- $\alpha$ in mast cells [39]. Additionally, activation of p38 MAP kinase was shown to stimulate IL-4 production in bone marrow derived mast cells [40]. When mast cells are stimulated via FceRI, the transcription factors $\mathrm{NF} \kappa \mathrm{B}$ and NFAT are translocated to the nucleus and initiate the transcription of genes for proinflammatory and regulatory cytokines. This results in the expression and release of cytokines [19, 41, 42]. Cross-linking GD1b derived gangliosides by mAbAA4 activates the transcription factors $\mathrm{NF} \kappa \mathrm{B}$ and NFAT. However, the degree of activation by ganglioside cross-linking was less than that observed by stimulation via FceRI. This reduction in activation is expected since the degree of MAP kinase phosphorylation after ganglioside cross-linking was less than that observed in mast cells stimulated via FceRI. Similar results have been reported for phosphorylation of Lyn, Syk, PLC $\gamma 1$, and the $\beta$ - and $\gamma$-subunits of FceRI [12].

The lower phosphorylation of MAP kinase resulted in a reduction in $\mathrm{NF} K \mathrm{~B}$ and NFAT activation leading to a decrease in IL- 4 and TNF- $\alpha$ release. In FceRI stimulated mast cells, activation of $\mathrm{NF} \kappa \mathrm{B}$ depends on PKC activation [43]. On the other hand, NFAT is activated by calcineurin induced dephosphorylation, a $\mathrm{Ca}^{2+}$-calmodulin dependent serine/threonine phosphatase that is activated by an increase in intracellular calcium $[44,45]$. mAbAA4 binding to RBL$2 \mathrm{H} 3$ mast cells results in a modest increase in intracellular calcium as well as in a partial redistribution of PKC [11], which could explain the reduced activation of $\mathrm{NF} \kappa \mathrm{B}$ and NFAT seen in the present study. Additionally, cross-linking GD1b derived gangliosides in Syk-negative cells did not stimulate the release of either newly formed or newly synthesized mediators. This is in agreement with previous studies that have shown that the inhibition or the lack of Syk results in the failure of mast cells to produce and release any mediators [46, 47]. Syk-negative mast cells are also unable to activate $\mathrm{NF} \kappa \mathrm{B}$ and NFAT in response to FceRI activation $[6,16]$.

The exact mechanism by which cross-linking the GDlb derived gangliosides causes the various effects observed both previously and in this study is still unknown. Several intracellular signals induced by mAbAA4 binding are very similar to those induced by FceRI activation. Binding of mAbAA4 to mast cells is known to stimulate protein tyrosine phosphorylation, including phosphorylation of Lyn, Syk, PLC $\gamma 1$, and the $\beta$ - and $\gamma$-subunits of FceRI. However, the rate of phosphorylation of Lyn, Syk, and PLC $\gamma 1$ was slower with ganglioside cross-linking than with FceRI stimulation [12]. In addition to these effects of mAbAA4, preincubation of RBL-2H3 cells with mAbAA4 selectively inhibits the degranulation induced by FceRI stimulation at a very early step of upstream receptor tyrosine phosphorylation. This inhibition is unrelated to mAbAA4 blocking IgE-binding to the cells $[48,49]$. Moreover, the GD1b derived gangliosides coimmunoprecipitate with FceRI [48] as well as with the tyrosine kinase Lyn [49]. Oliver et al. [50] demonstrated that in RBL-2H3 cells stimulated via FceRI, the gangliosides and FceRI are internalized together and follow the same intracellular endocytic pathway suggesting that the GD1b derived gangliosides are involved in the organization of the signaling complex.

\section{Conclusions}

The present study has demonstrated that cross-linking the GD1b derived gangliosides stimulates the release of newly formed and newly synthesized mediators. Although these gangliosides are intimately associated with FceRI, the ability of the gangliosides to activate mast cells is not dependent on FceRI cross-linking. The present study helps to explain the extremely broad spectrum of potential mechanisms by which mast cells might act in suppressing, amplifying, and modulating the non-FceRI mediated immune responses. Furthermore, an understanding of the role of gangliosides in mast cell activation may lead to new therapeutic targets for allergic and inflammatory processes.

\section{Competing Interests}

The authors declare no competing financial interests.

\section{Acknowledgments}

The authors would like to thank Dr. Rita de Cassia Aleixo Tostes Passaglia from the Department of Pharmacology, FMRP-USP, Ribeirão Preto, SP, Brazil, for kindly providing the IL-6 ELISA kit and antibodies against phosphorylated proteins. This work was supported by Fundação de Amparo à Pesquisa do Estado de São Paulo, FAPESP (2014/17671-8, MCJ; 2013/12861-0, EGFF; 2012/06373-0, EZMS).

\section{References}

[1] A. M. M. Silveira e Souza, M. C. Jamur, and C. Oliver, "The importance of gangliosides in mast cell biology," in Glycolipids: New Research, D. Sasaki, Ed., pp. 53-78, Nova Science, New York, NY, USA, 2008.

[2] R. K. Yu, Y.-T. Tsai, T. Ariga, and M. Yanagisawa, "Structures, biosynthesis, and functions of gangliosides-an overview," Journal of Oleo Science, vol. 60, no. 10, pp. 537-544, 2011.

[3] J. L. Daniotti, R. D. Lardone, and A. A. Vilcaes, "Dysregulated expression of glycolipids in tumor cells: from negative modulator of anti-tumor immunity to promising targets for developing therapeutic agents," Frontiers in Oncology, vol. 5, article 300, 2016.

[4] E. Z. M. da Silva, M. C. Jamur, and C. Oliver, "Mast cell function: a new vision of an old cell," Journal of Histochemistry and Cytochemistry, vol. 62, no. 10, pp. 698-738, 2014. 
[5] S. J. Galli, "The mast cell-IgE paradox: from homeostasis to anaphylaxis," The American Journal of Pathology, vol. 186, no. 2, pp. 212-224, 2016.

[6] R. O. de Castro, J. Zhang, M. C. Jamur, C. Oliver, and R. P. Siraganian, "Tyrosines in the carboxyl terminus regulate Syk kinase activity and function," The Journal of Biological Chemistry, vol. 285, no. 34, pp. 26674-26684, 2010.

[7] M. Krystel-Whittemore, K. N. Dileepan, and J. G. Wood, "Mast cell: a multi-functional master cell," Frontiers in Immunology, vol. 6, article 620, 2016.

[8] J. Rivera, N. A. Fierro, A. Olivera, and R. Suzuki, "New insights on mast cell activation via the high affinity receptor for IgE," Advances in Immunology, vol. 98, pp. 85-120, 2008.

[9] N. H. Guo, G. R. Her, V. N. Reinhold, M. J. Brennan, R. P. Siraganian, and V. Ginsburg, "Monoclonal antibody AA4, which inhibits binding of IgE to high affinity receptors on rat basophilic leukemia cells, binds to novel $\alpha$-galactosyl derivatives of gangliosides G(D1b)," The Journal of Biological Chemistry, vol. 264, no. 22, pp. 13267-13272, 1989.

[10] L. A. K. Basciano, E. H. Berenstein, L. Kmak, and R. P. Siraganian, "Monoclonal antibodies that inhibit IgE binding," Journal of Biological Chemistry, vol. 261, no. 25, pp. 11823-11831, 1986.

[11] C. Oliver, N. Sahara, S. Kitani, A. R. Robbins, L. M. Mertz, and R. P. Siraganian, "Binding of monoclonal antibody AA4 to gangliosides on rat basophilic leukemia cells produces changes similar to those seen with fee receptor activation," Journal of Cell Biology, vol. 116, no. 3, pp. 635-646, 1992.

[12] W. D. Swaim, K. Minoguchi, C. Oliver et al., "The antiganglioside monoclonal antibody AA4 induces protein tyrosine phosphorylations, but not degranulation, in rat basophilic leukemia cells," Journal of Biological Chemistry, vol. 269, no. 30, pp. 19466-19473, 1994.

[13] E. L. Barsumian, C. Isersky, M. G. Petrino, and R. P. Siraganian, "IgE-induced histamine release from rat basophilic leukemia cell lines: isolation of releasing and nonreleasing clones," European Journal of Immunology, vol. 11, no. 4, pp. 317-323, 1981.

[14] J. Zhang, K. Suzuki, T. Hitomi, and R. P. Siraganian, "TOM1L1 is a Lyn substrate involved in Fc $\in$ RI signaling in mast cells," Journal of Biological Chemistry, vol. 282, no. 52, pp. 3766937677, 2007.

[15] C. X. R. Valim, E. Z. M. da Silva, M. A. Assis et al., "RPbPgal from paracoccidioides brasiliensis activates mast cells and macrophages via NFאB," PLoS Neglected Tropical Diseases, vol. 9, no. 8, 2015

[16] A. C. G. Grodzki, K. D. Moon, E. H. Berenstein, and R. P. Siraganian, "FceRI-induced activation by low antigen concentrations results in nuclear signals in the absence of degranulation," Molecular Immunology, vol. 46, no. 13, pp. 2539-2547, 2009.

[17] A. M. M. Silveira e Souza, V. M. Mazucato, R. O. de Castro et al., "The $\alpha$-galactosyl derivatives of ganglioside GDlb are essential for the organization of lipid rafts in RBL-2H3 mast cells," Experimental Cell Research, vol. 314, no. 13, pp. 2515-2528, 2008.

[18] Y. Lu, Y. Li, C.-S. Seo, M. Murakami, J.-K. Son, and H. W. Chang, "Saucerneol D inhibits eicosanoid generation and degranulation through suppression of Syk kinase in mast cells," Food and Chemical Toxicology, vol. 50, no. 12, pp. 4382-4388, 2012.

[19] A. M. Gilfillan and C. Tkaczyk, "Integrated signalling pathways for mast-cell activation," Nature Reviews Immunology, vol. 6, no. 3, pp. 218-230, 2006.
[20] R. P. Siraganian, "Mast cell signal transduction from the highaffinity IgE receptor," Current Opinion in Immunology, vol. 15, no. 6, pp. 639-646, 2003.

[21] U. Blank, I. K. Madera-Salcedo, L. Danelli et al., "Vesicular trafficking and signaling for cytokine and chemokine secretion in mast cells," Frontiers in Immunology, vol. 5, article 453, 2014.

[22] P. L. Triozzi, J. J. Shah, W.-Q. Wang et al., "Anti-GD3 monoclonal antibody effects on lymphocytes and antibody-dependent cellular cytotoxicity," Cancer Biotherapy and Radiopharmaceuticals, vol. 21, no. 6, pp. 553-560, 2006.

[23] J. Wang, Z.-H. Lu, H.-J. Gabius, C. Rohowsky-Kochan, R. W. Ledeen, and G. Wu, "Cross-linking of GM1 ganglioside by galectin-1 mediates regulatory $\mathrm{T}$ cell activity involving TRPC5 channel activation: possible role in suppressing experimental autoimmune encephalomyelitis," Journal of Immunology, vol. 182, no. 7, pp. 4036-4045, 2009.

[24] G. Wu, Z.-H. Lu, A. G. Obukhov, M. C. Nowycky, and R. W. Ledeen, "Induction of calcium influx through TRPC5 channels by cross-linking of GM1 ganglioside associated with $\alpha 5 \beta 1$ integrin initiates neurite outgrowth," The Journal of Neuroscience, vol. 27, no. 28, pp. 7447-7458, 2007.

[25] K. Nohara, M. Kunimoto, and H. Fujimaki, "Antibody against ganglioside GD1c containing NeuGc $\alpha 2-8 \mathrm{NeuGc}$ cooperates with CD3 and CD4 in rat T cell activation," The Journal of Biochemistry, vol. 124, no. 1, pp. 194-199, 1998.

[26] T. O. Nashar, N. A. Williams, and T. R. Hirst, "Cross-linking of cell surface ganglioside GM1 induces the selective apoptosis of mature CD $8^{+}$T lymphocytes," International Immunology, vol. 8, no. 5, pp. 731-736, 1996.

[27] P. Hersey, S. Schibeci, and D. Cheresh, "Augmentation of lymphocyte responses by monoclonal antibodies to the gangliosides GD3 and GD2: the role of protein kinase C, cyclic nucleotides, and intracellular calcium," Cellular Immunology, vol. 119, no. 2, pp. 263-278, 1989.

[28] Y. Norihisa, D. W. McVicar, P. Ghosh et al., "Increased proliferation, cytotoxicity, and gene expression after stimulation of human peripheral blood T lymphocytes through a surface ganglioside (GD3)," Journal of Immunology, vol. 152, no. 2, pp. 485-495, 1994.

[29] C. A. Dyer and J. A. Benjamins, "Glycolipids and transmembrane signaling: antibodies to galactocerebroside cause an influx of calcium in oligodendrocytes," Journal of Cell Biology, vol. 111, no. 2, pp. 625-633, 1990.

[30] N. M. van Sorge, L. H. van den Berg, K. Geleijns et al., "AntiGM1 IgG antibodies induce leukocyte effector functions via Fc $\gamma$ receptors," Annals of Neurology, vol. 53, no. 5, pp. 570-579, 2003.

[31] J. A. Boyce, "Mast cells and eicosanoid mediators: a system of reciprocal paracrine and autocrine regulation," Immunological Reviews, vol. 217, no. 1, pp. 168-185, 2007.

[32] B. L. Diaz, H. Fujishima, A. Sapirstein, J. V. Bonventre, and J. P. Arm, "Participation of cytosolic phospholipase A2 in eicosanoid generation by mouse bone marrow-derived mast cells," Advances in Experimental Medicine and Biology, vol. 507, pp. 41-46, 2002.

[33] T. Hirabayashi and T. Shimizu, "Localization and regulation of cytosolic phospholipase $\mathrm{A}_{2}$," Biochimica et Biophysica Acta (BBA)-Molecular and Cell Biology of Lipids, vol. 1488, no. 1-2, pp. 124-138, 2000.

[34] S. T. Reddy and H. R. Herschman, "Prostaglandin synthase-1 and prostaglandin synthase- 2 are coupled to distinct phospholipases for the generation of prostaglandin D2 in activated mast 
cells," The Journal of Biological Chemistry, vol. 272, no. 6, pp. 3231-3237, 1997.

[35] S. J. Galli and M. Tsai, "Mast cells: versatile regulators of inflammation, tissue remodeling, host defense and homeostasis," Journal of Dermatological Science, vol. 49, no. 1, pp. 7-19, 2008.

[36] T. C. Theoharides, D. Kempuraj, M. Tagen, P. Conti, and D. Kalogeromitros, "Differential release of mast cell mediators and the pathogenesis of inflammation," Immunological Reviews, vol. 217, no. 1, pp. 65-78, 2007.

[37] T. C. Moon, A. D. Befus, and M. Kulka, "Mast cell mediators: their differential release and the secretory pathways involved," Frontiers in Immunology, vol. 5, article 569, 2014.

[38] A. Lorentz, I. Klopp, T. Gebhardt, M. P. Manns, and S. C. Bischoff, "Role of activator protein 1 , nuclear factor- $\kappa \mathrm{B}$, and nuclear factor of activated T cells in IgE receptor-mediated cytokine expression in mature human mast cells," Journal of Allergy and Clinical Immunology, vol. 111, no. 5, pp. 1062-1068, 2003.

[39] Y. Kawakami, S. E. Hartman, P. M. Holland, J. A. Cooper, and T. Kawakami, "Multiple signaling pathways for the activation of JNK in mast cells: involvement of Bruton's tyrosine kinase, protein kinase C, and JNK kinases, SEK1 and MKK7," Journal of Immunology, vol. 161, no. 4, pp. 1795-1802, 1998.

[40] B. Frossi, J. Rivera, E. Hirsch, and C. Pucillo, "Selective activation of Fyn/PI3K and p38 MAPK regulates IL-4 production in BMMC under nontoxic stress condition," Journal of Immunology, vol. 178, no. 4, pp. 2549-2555, 2007.

[41] S. Monticelli, D. C. Solymar, and A. Rao, "Role of NFAT proteins in IL13 gene transcription in mast cells," The Journal of Biological Chemistry, vol. 279, no. 35, pp. 36210-36218, 2004.

[42] H. Okamura, J. Aramburu, C. García-Rodríguez et al., "Concerted dephosphorylation of the transcription factor NFAT1 induces a conformational switch that regulates transcriptional activity," Molecular Cell, vol. 6, no. 3, pp. 539-550, 2000.

[43] S. Klemm and J. Ruland, "Inflammatory signal transduction from the FceRI to NF- $\kappa$ B," Immunobiology, vol. 211, no. 10, pp. 815-820, 2006.

[44] Y. Gwack, S. Feske, S. Srikanth, P. G. Hogan, and A. Rao, "Signalling to transcription: store-operated $\mathrm{Ca}^{2+}$ entry and NFAT activation in lymphocytes," Cell Calcium, vol. 42, no. 2, pp. 145-156, 2007.

[45] M. Klein, S. Klein-Hessling, A. Palmetshofer et al., "Specific and redundant roles for NFAT transcription factors in the expression of mast cell-derived cytokines," Journal of Immunology, vol. 177, no. 10, pp. 6667-6674, 2006.

[46] J. Zhang, T. Kimura, and R. P. Siraganian, "Mutations in the activation loop tyrosines of protein tyrosine kinase Syk abrogate intracellular signaling but not kinase activity," Journal of Immunology, vol. 161, no. 8, pp. 4366-4374, 1998.

[47] A. B. Rossi, E. Herlaar, S. Braselmann et al., "Identification of the Syk kinase inhibitor R112 by a human mast cell screen," Journal of Allergy and Clinical Immunology, vol. 118, no. 3, pp. 749-755, 2006.

[48] V. Stephan, A. Seibt, D. Dukanovic et al., "Anti-ganglioside monoclonal antibody AA4 selectively inhibits IgE- induced signal transduction pathways in rat basophilic leukemia cells," Molecular Immunology, vol. 34, no. 3, pp. 227-235, 1997.

[49] K. Minoguchi, W. D. Swaim, E. H. Berenstein, and R. P. Siraganian, "Src family tyrosine kinase p53/56lyn, a serine kinase and FceRI associate with $\alpha$-galactosyl derivatives of ganglioside GD1b in rat basophilic leukemia RBL-2H3 cells," Journal of Biological Chemistry, vol. 269, no. 7, pp. 5249-5254, 1994.

[50] C. Oliver, A. Fujimura, A. M. M. Silveira E Souza, R. O. De Castro, R. P. Siraganian, and M. C. Jamur, "Mast cell-specific gangliosides and FceRI follow the same endocytic pathway from lipid rafts in RBL-2H3 cells," Journal of Histochemistry and Cytochemistry, vol. 55, no. 4, pp. 315-325, 2007. 


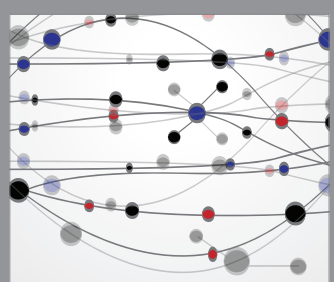

The Scientific World Journal
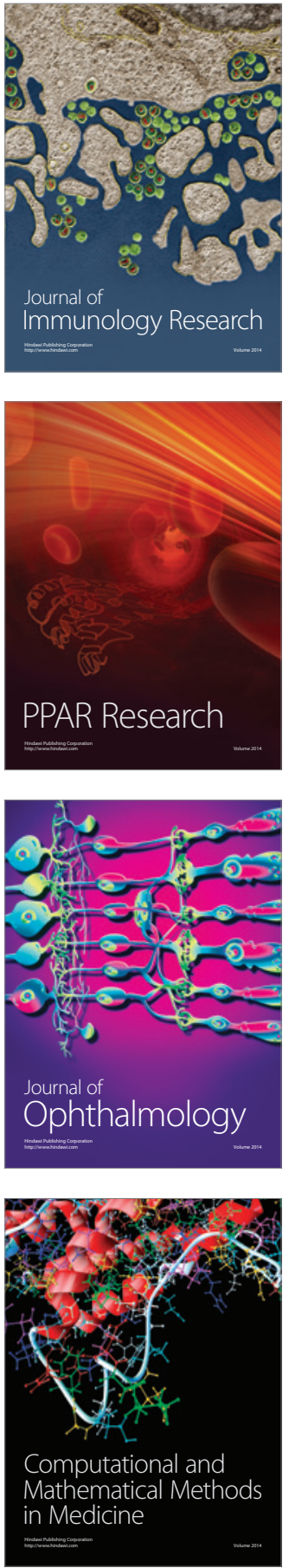

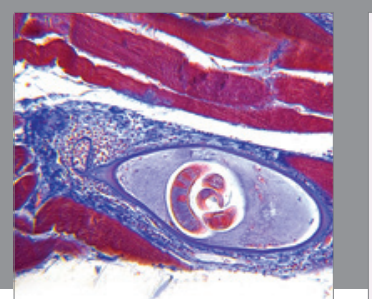

Gastroenterology Research and Practice

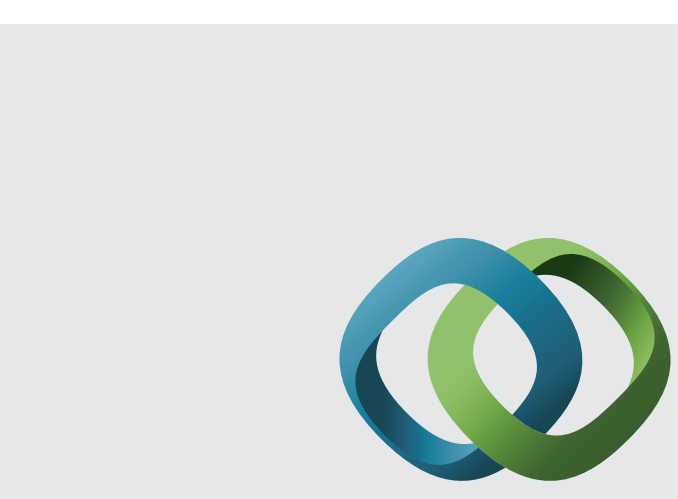

\section{Hindawi}

Submit your manuscripts at

http://www.hindawi.com
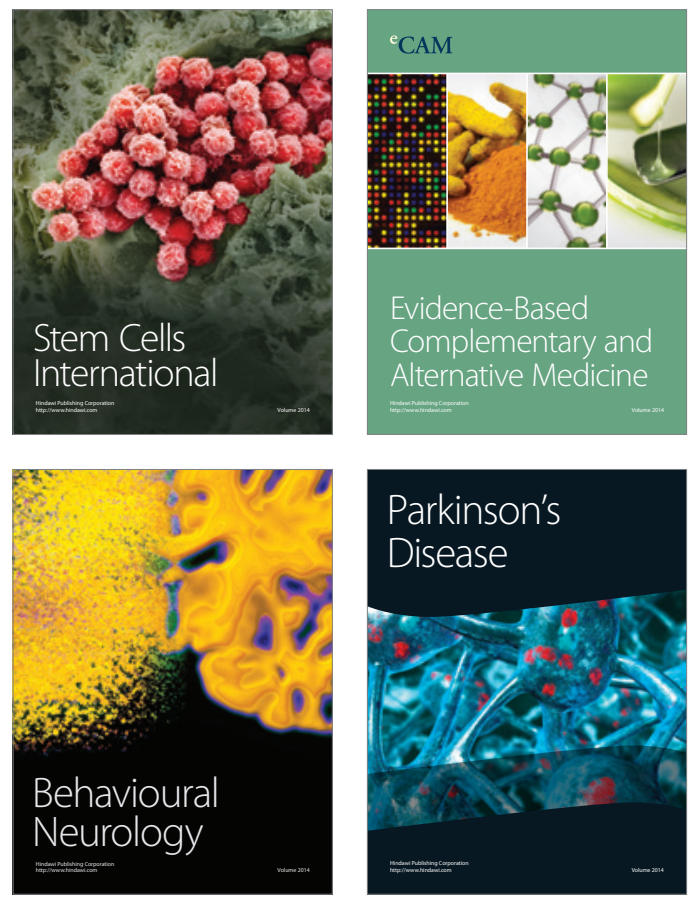
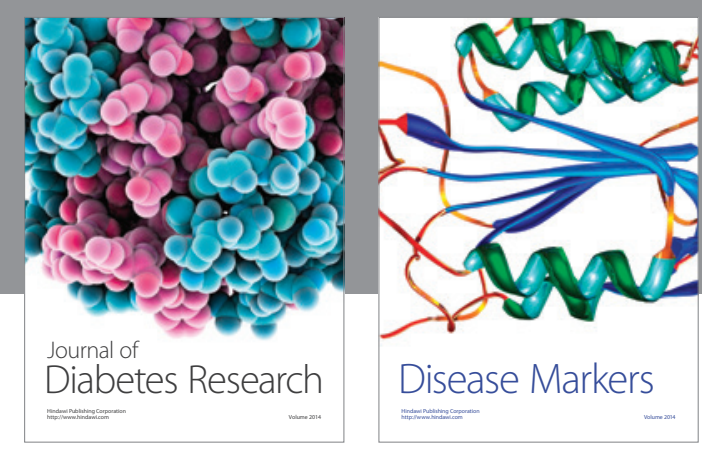

Disease Markers
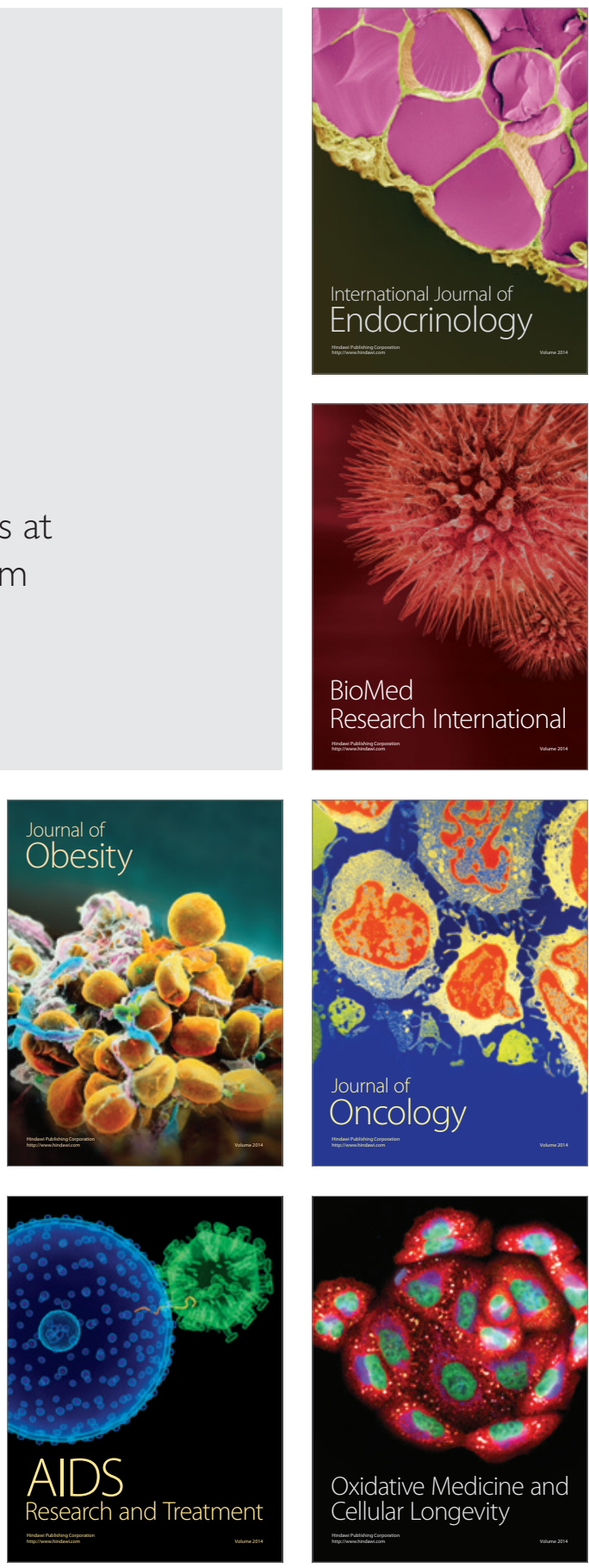


\section{Supplementary Material}

A

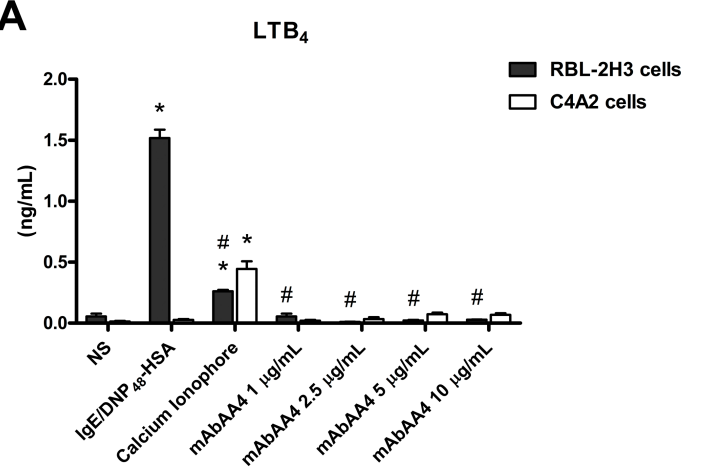

C

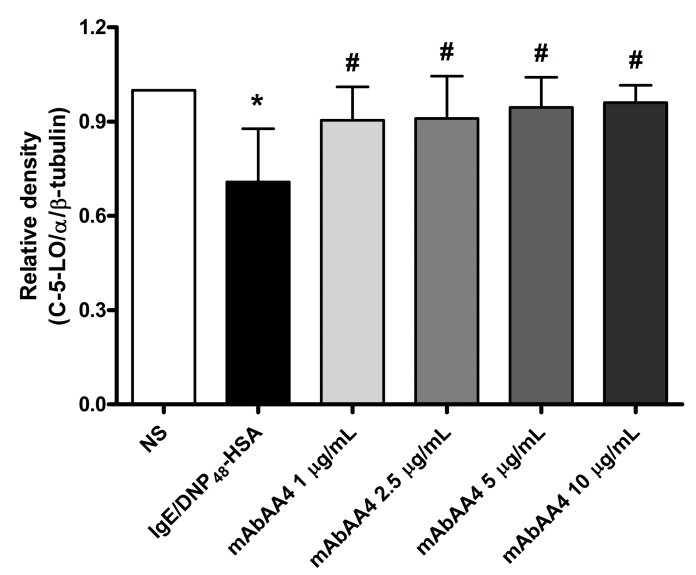

D

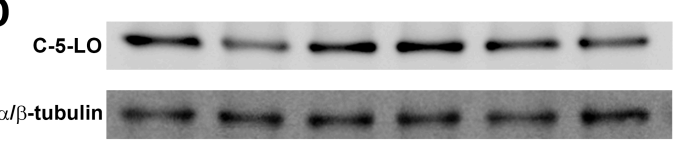

B

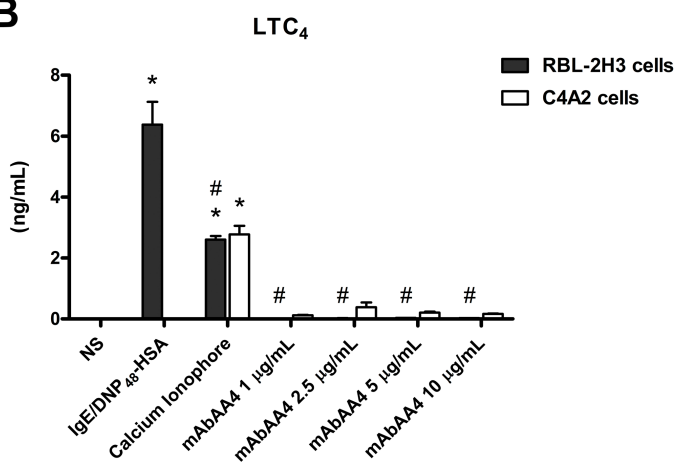

E

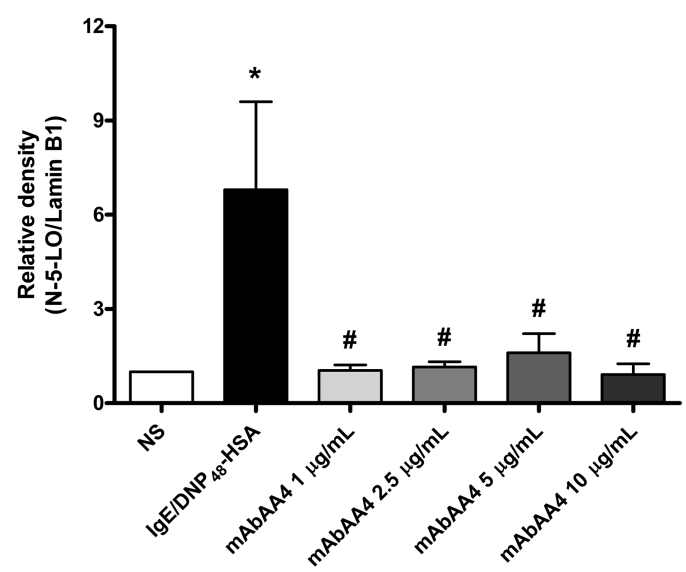

$\mathbf{F}$

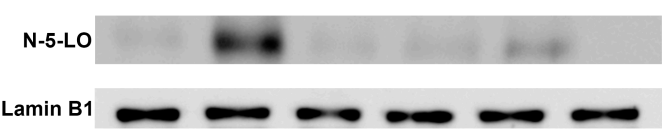

Supplementary Fig. 1. Cross-linking GD1b derived gangliosides by mAbAA4 did not induce the release of $\mathrm{LTB}_{4}$ or $\mathrm{LTC}_{4}$ or the translocation of 5-LO. In order to evaluate leukotriene release, RBL-2H3 cells and C4A2 Syk-negative cells were sensitized with IgE anti-TNP and stimulated with $\mathrm{DNP}_{48}-\mathrm{HSA}(50 \mathrm{ng} / \mathrm{mL})$ for stimulation via FceRI. For FceRI independent stimulation, the cells were incubated with calcium ionophore $(0.1 \mu \mathrm{g} / \mathrm{mL})$. To cross-link GD1b derived gangliosides, cells were incubated with mAbAA4 $(1,2.5,5$, and $10 \mu \mathrm{g} / \mathrm{mL})$. Nonstimulated (NS) cells were used as negative controls. Culture supernatants were collected after 30 min to evaluate $\mathrm{LT}$ release. $\mathrm{LTB}_{4}(\mathrm{~A})$ and $\mathrm{LTC}_{4}(\mathrm{~B})$ were measured in the culture 
supernatants by EIA. To examine 5-LO translocation, RBL-2H3 cells were either stimulated via FceRI, where cells were sensitized with IgE anti-TNP and stimulated with $\mathrm{DNP}_{48}$-HSA (50 $\mathrm{ng} / \mathrm{mL})$, or incubated with mAbAA4 $(1,2.5,5$, and $10 \mu \mathrm{g} / \mathrm{mL})$ for $5 \mathrm{~min}$. Cytosolic and nuclear lysates were immunoblotted with antibodies against 5-LO, $\alpha / \beta$-tubulin, and Lamin B1 and the mean optical density of the bands was determined. Data were expressed as the fold of nonstimulated (NS) cells. (C) ratio of cytosolic 5-LO (C-5-LO)/ $\alpha / \beta$-tubulin (housekeeping protein from the cytosolic fraction); (D) a representative blot from C; (E) ratio of nuclear 5-LO (N-5LO)/Lamin B1 (housekeeping protein from the nuclear fraction); (F) a representative blot from E. Data is expressed as the mean $\pm \mathrm{SD}$ of three independent experiments. ${ }^{*} P<0.05$ between experimental samples and the non-stimulated (NS) cells. ${ }^{\#} P<0.05$ between experimental samples and FceRI stimulated cells. 


\subsection{CHAPTER II}

Title: Proteomic analysis of lipid rafts from RBL-2H3 mast cells

Authors: Edismauro Garcia Freitas Filho, Luiz Augusto Marin Jaca, Lilian Cristiane Baeza, Maria de Almeida Soares, Clayton Luiz Borges, Constance Oliver, and Maria Célia Jamur

Journal: International Journal of Molecular Sciences (2019), 20(16), 3904;

https://doi.org/10.3390/ijms20163904 (registering DOI). Impact Factor: 4.18. 


\title{
Proteomic Analysis of Lipid Rafts from RBL-2H3 Mast Cells
}

\author{
Edismauro Garcia Freitas Filho ${ }^{1}$ (D), Luiz Augusto Marin Jaca ${ }^{1}$, Lilian Cristiane Baeza ${ }^{2}$, \\ Célia Maria de Almeida Soares ${ }^{2}$, Clayton Luiz Borges ${ }^{2}$, Constance Oliver ${ }^{1}{ }^{\circledR}$ and \\ Maria Célia Jamur ${ }^{1, *(\mathbb{D})}$ \\ 1 Department of Cell and Molecular Biology and Pathogenic Bioagents, Ribeirão Preto Medical School, \\ University of São Paulo, Av. Bandeirantes 3900, Ribeirão Preto, SP, 14049-900, Brazil \\ 2 Molecular Biology Laboratory, Biological Science Institute, Federal University of Goiás, Samambaia Campus \\ II, ICB2, room 206, Goiânia, GO, 74690-900, Brazil \\ * Correspondence: mjamur@fmrp.usp.br; Tel.: +55-163315-3142
}

Received: 8 July 2019; Accepted: 8 August 2019; Published: 11 August 2019

check for updates

\begin{abstract}
Lipid rafts are highly ordered membrane microdomains enriched in cholesterol, glycosphingolipids, and certain proteins. They are involved in the regulation of cellular processes in diverse cell types, including mast cells (MCs). The MC lipid raft protein composition was assessed using qualitative mass spectrometric characterization of the proteome from detergent-resistant membrane fractions from RBL-2H3 MCs. Using two different post-isolation treatment methods, a total of 949 lipid raft associated proteins were identified. The majority of these MC lipid raft proteins had already been described in the RaftProtV2 database and are among highest cited/experimentally validated lipid raft proteins. Additionally, more than half of the identified proteins had lipid modifications and/or transmembrane domains. Classification of identified proteins into functional categories showed that the proteins were associated with cellular membrane compartments, and with some biological and molecular functions, such as regulation, localization, binding, catalytic activity, and response to stimulus. Furthermore, functional enrichment analysis demonstrated an intimate involvement of identified proteins with various aspects of MC biological processes, especially those related to regulated secretion, organization/stabilization of macromolecules complexes, and signal transduction. This study represents the first comprehensive proteomic profile of MC lipid rafts and provides additional information to elucidate immunoregulatory functions coordinated by raft proteins in MCs.
\end{abstract}

Keywords: lipid rafts; membrane proteins; protein localization; regulated secretion; signaling pathway; proteome; mast cells

\section{Introduction}

Lipid rafts are dynamic ordered nanoscale assemblies in the plasma membrane and other intracellular membranes, and are enriched in cholesterol and glycosphingolipids [1,2]. They are characterized by the presence of proteins with lipid modifications, as well as proteins involved in signal transduction. Due to their composition, they are resistant to solubilization in nonionic mild detergents [1,3]. Lipid raft components can diffuse laterally in the plasma membrane, thus lipid raft microdomains have the ability to associate and dissociate on a subsecond timescale, and vary in stability, size, shape, lifetime, and molecular composition [3-5]. The compartmentalization of molecules into lipid rafts provides a favorable environment to facilitate interactions among the raft components. Therefore, lipid rafts act as platforms to segregate lipids, receptors, adaptors, kinases, 
scaffolding proteins, and cytoskeletal apparatus that trigger complex events and coordinate diverse biological processes [2,6-10].

Since the total protein content of lipid rafts can be extensive, these microdomains are an attractive target for mass-spectrometry (MS)-based proteomics. Proteomic strategies have been applied to lipid rafts from a variety of tissue and cell types, including rat brain [11], Hella cells [12], ovarian cancer cells [13], and immune cells, such as neutrophils [14,15], monocytes [16], and macrophages [17], as well as lymphocytes T [18,19], B [20], and natural killer cells [21], with the aim of better identifying the proteins present in lipid rafts [22-25]. Functional proteomic analysis of lipid raft proteins examines the relationship between individual proteins and clusters them based on characteristics such as structure, localization, binding partners, and post translational modification, which has led to the elucidation of novel molecular pathways and biological events coordinated by these membrane microdomains [23,25-27].

Mast cells (MCs) are multifunctional immune cells that, in addition to their well-established role in allergic and anaphylactic reactions, are implicated in innate and adaptive immunity, and in inflammation among other physiological and pathological processes [28-30]. Lipid rafts modulate many important biological processes related to these MC functions, such as degranulation, endocytosis, play a role in $\mathrm{MC}$ development and recruitment, and contribute to the preservation of $\mathrm{MC}$ structure and organization [6,31-33]. However, there is no MC lipid raft proteome available. Only a few studies report on the whole MC plasma membrane composition, using MS for lipid characterization [34] or protein identification using MALDI-TOF (matrix-assisted laser desorption/ionization and time-of-flight) or LC-MS/MS (liquid chromatography-mass spectrometry) [35-37]. Moreover, only a limited number of proteins have been annotated and a non-detailed functional analysis was performed.

The present study was undertaken to investigate the qualitative proteomic profile of MC lipid rafts using the rat mucosal MC line RBL-2H3. While the investigation of lipid rafts in MCs has largely been done using RBL-2H3 MCs [38], there is no proteomic profile of lipid rafts from RBL-2H3 MCs or any other MC. Although controversy exists over the exact character of RBL-2H3 MCs [39,40], they are still a widely accepted model for functional studies of MC dynamics. Since the RBL-2H3 MC line was first identified in 1973 [41], and later cloned and characterized [42], it has become one the most commonly used models to study MC function [40]. RBL-2H3 MCs provide many advantages over primary MCs. They may be grown in large amounts in culture and can easily be genetically manipulated. RBL-2H3 MCs have also been used to study signaling pathways following FceRI (high-affinity IgE receptor) activation and MC regulated exocytosis, events in which lipid rafts are involved. More recently, RBL-2H3 MCs have also been used as a model for studies focused on the detection of allergens, diagnosis of allergic sensitization, and vaccine safety studies [40]. Even considering the problem of MC heterogeneity, the findings provided by RBL-2H3 MCs have substantially contributed to a global understanding of MC function. The results of the present investigation show that the methods applied here were efficient in identifying lipid raft proteins in MCs and these raft microdomains are involved in the regulated secretion, organization, and stabilization of macromolecular complexes, as well as signaling transduction pathways important to MC biological functions. This qualitative proteomic data should provide a more complete understanding of lipid rafts in MC biology.

\section{Results}

\subsection{Obtention of Lipid Rafts from RBL-2H3 Mast Cells}

Lipid rafts were isolated from RBL-2H3 MCs using discontinuous sucrose-density gradient ultracentrifugation. LAT1 (linker for activation of T-cells 1), a lipid-raft-specific protein in immune cells $[43,44]$, was used as a marker for the lipid rafts. Using immunoblotting, LAT1 was highly enriched in Fractions 2 and 3. In addition, the SFK (Src family kinase) Lyn, and the rodent MC-specific GD1b-derived gangliosides, both well-characterized MC lipid raft components [45,46], were also enriched in Fractions 2 and 3 (Figure 1). Additionally, Flotillin-1, a widely used marker of lipid rafts [8], 
was also concentrated in Fractions 2 and 3. Thus, Fractions 2 and 3 represent the lipid raft fractions in these preparations. In contrast, Histone H3, a nuclear protein, was concentrated in Fractions 9 and 10.

\section{Enriched Lipid Rafts}

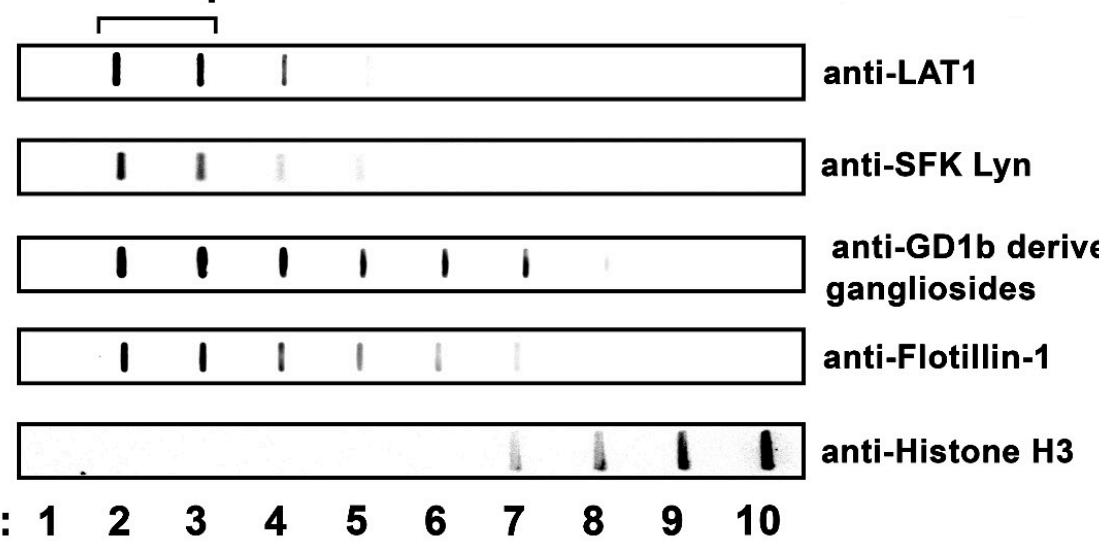

\section{Fractions: $1 \begin{array}{llllllllll}1 & 2 & 3 & 4 & 5 & 6 & 7 & 8 & 9 & 10\end{array}$}

Figure 1. Identification of RBL-2H3 mast cell lipid rafts. Lysates of RBL-2H3 MCs were fractionated using sucrose density gradient ultracentrifugation, and fractions were immunoblotted using antibodies against lipid raft markers: LAT1, SFK Lyn, rodent MC-specific GD1b-derived gangliosides, and Flotillin-1. Proteins and lipids associated with lipid rafts were concentrated in Fractions 2 and 3. Fractions were also immunoblotted with anti-Histone H3, a nuclear protein. Data representative of three independent experiments is shown.

\subsection{Identification of Mast Cell Lipid Raft Proteins Using Nano-UPLC-MSE}

The lipid raft fractions (Fractions 2 and 3) obtained from three independent experiments were pooled. The resulting sample was divided and used for two different post-isolation treatment methods, Method I (MetI) and Method II (MetII). MetI eliminated the sucrose from the enriched lipid raft fractions prior to MS analysis. MetII was harsher than MetI and involved mixing the sample with OGP (octyl $\beta$-glucopyranoside) detergent followed by a final methanol-chloroform extraction. The solubilized proteins obtained from the lipid raft fractions after the post-isolation treatments were submitted to nano-UPLC-MS ${ }^{\mathrm{E}}$ analysis. The samples were run in three technical replicates and only proteins identified in two out of the three replicates were considered for further analysis. The obtained UPLC-MSE protein data generated by the PLGS was processed to verify the quality of the proteomic analysis (Figure S1: Dynamic range of the proteomic analysis). For reliable protein identification, a reverse sequence database of Rattus norvegicus was used to calculate the false rate. The false positive rates of proteins obtained from MetI and MetII were, respectively, $1.04 \%$ and $0.36 \%$. Supplementary Figure S1 depicts the results obtained from an analysis of the dynamic range indicating that a $3 \log$ difference in abundance and a good distribution of both high and low concentrations of the proteins were obtained with both methods. This approach ensured the selection of highly representative proteins.

After processing, according to the criteria stated in Section 5.6, 429 proteins were identified in MetI (Table S1: Detailed annotation of proteins identified in Method I), and 753 in MetII (Table S2: Detailed annotation of proteins identified in Method II); 196 proteins were exclusively identified in MetI and 520 proteins were exclusively identified in MetII, and 233 proteins were common between the methods. In total, 949 proteins were identified (Figure 2) (Table S3: Detailed annotation of proteins identified in Methods I and II). 


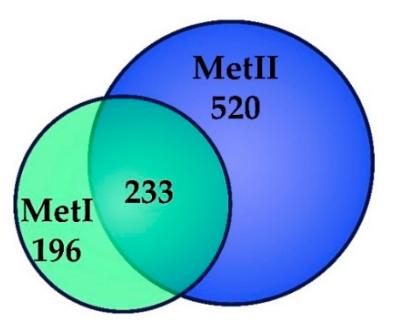

Figure 2. Proteomic identification of lipid raft enriched fractions of RBL-2H3 mast cells. MC lipid-raft-enriched Fractions 2 and 3 were used for Nano-UPLC-MS ${ }^{\mathrm{E}}$ analysis. A Venn diagram depicting the number of overlapping and unique proteins present in MC lipid rafts processed using Method I (MetI) and Method II (MetII) is shown.

\subsection{Characterization of Mast Cell Lipid Raft Proteins}

The 949 identified proteins were then analyzed to determine whether they had been previously reported as lipid raft proteins or had characteristic modifications of lipid raft proteins. Of the 949 identified proteins, $855(\approx 90 \%$; 855/949) were found in the RaftProtV2 database as previously reported lipid raft proteins [26], while 94 of the proteins had not been previously annotated (Table S4: Mast cell lipid raft proteins absent from RaftProtV2 database, and Figure S2: Immuno-blot analysis of the $\beta$-subunit of FceRI from RBL-2H3 MC lipid rafts). Of the previously annotated proteins, 172 were unique to MetI and 454 to MetII, thus indicating that MetII was more efficient in extracting lipid raft proteins (Table S5: Mast cell lipid raft proteins analyzed by RafProtV2 database). A total of $570(\approx 67 \%$; $570 / 855)$ of these proteins were classified as high-confidence lipid raft proteins based on experimental evidence according to the RaftProtV2 database, confirming that these proteins were indeed lipid raft proteins. The proteins with the highest number of citations supported by experimental evidence are listed in Table 1.

Lipid modifications are one of the characteristics of lipid-raft-associated proteins [1]. Therefore, all the identified proteins were examined for lipid modifications using bioinformatic analysis. Almost half of the identified proteins $(46.8 \% ; 444 / 949)$ had at least one lipid modification: S-palmitoylation, isoprenylation, N-myristoylation, or GPI (glycophosphatidylinositol) anchor. There was basically no difference in the percentage of proteins with lipid modifications extracted with either MetI $(50.3 \%$; 216/429) or MetII (48\%; 361/753). However, MetII had a higher number of proteins with lipid modification in all categories analyzed (Figure 3).

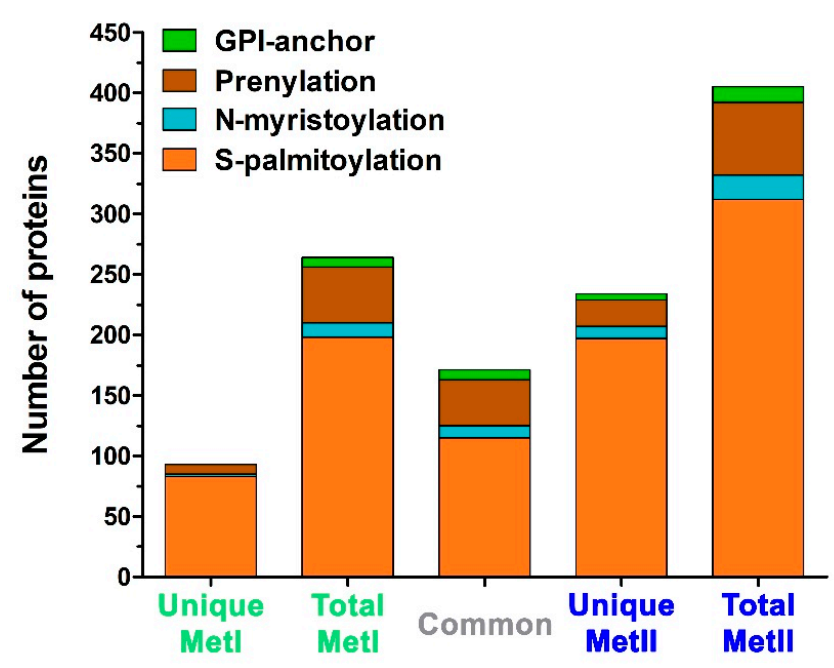

Figure 3. Proteins with an annotated lipid modification identified in mast cell lipid rafts isolated using Method I or Method II. Databases used: PhosphoSitePlus, SwissPalm, MYRbase, PRENbase, and PredGPI. 
Table 1. Mast cell lipid raft proteins annotated with the highest number of citations supported by experimental evidence in RaftProtV2 database.

\begin{tabular}{|c|c|c|c|c|c|}
\hline Method & $\begin{array}{l}\text { Protein } \\
\text { Accession }\end{array}$ & Protein Description & $\begin{array}{l}\text { Gene } \\
\text { Name }\end{array}$ & $\begin{array}{l}\text { Experimental } \\
\text { Evidence }\end{array}$ & $\begin{array}{l}\text { Number of } \\
\text { Citations }\end{array}$ \\
\hline MetII & P63018 & $\begin{array}{l}\text { Heat shock cognate } 71 \mathrm{kDa} \\
\text { protein }\end{array}$ & Hspa8 & $\mathrm{H}$ (3) M (3) R (3) & 102 \\
\hline MetII & Q9Z1E1 & Flotillin-1 & Flot1 & $\mathrm{H}(3) \mathrm{M}(1) \mathrm{R}(3)$ & 101 \\
\hline MetI; MetII & P15999 & $\begin{array}{l}\text { ATP synthase subunit alpha } \\
\text { mitochondrial }\end{array}$ & Atp5fla & H (3) M (3) R (3) & 98 \\
\hline MetI & P10719 & $\begin{array}{l}\text { ATP synthase subunit beta } \\
\text { mitochondrial }\end{array}$ & Atp5f1b & $\mathrm{H}(1) \mathrm{M}(1) \mathrm{R}(3)$ & 97 \\
\hline MetI; MetII & Q9Z2L0 & $\begin{array}{l}\text { Voltage-dependent } \\
\text { anion-selective channel protein } 1\end{array}$ & Vdac1 & $\mathrm{H}$ (3) M (3) R (3) & 97 \\
\hline MetI; MetII & P67779 & Prohibitin & $\mathrm{Phb}$ & $\mathrm{H}(3) \mathrm{M}(1) \mathrm{R}(1)$ & 91 \\
\hline MetI; MetII & P60711 & Actin cytoplasmic 1 & Actb & H (3) M (3) R (3) & 90 \\
\hline MetII & Q9Z2S9 & Flotillin-2 & Flot2 & H (3) M (3) R (3) & 90 \\
\hline MetI; MetII & P81155 & $\begin{array}{l}\text { Voltage-dependent } \\
\text { anion-selective channel protein } 2\end{array}$ & Vdac2 & $\mathrm{H}$ (3) M (3) R (1) & 90 \\
\hline MetI; MetII & P06685 & $\begin{array}{l}\text { Sodium/potassium-transporting } \\
\text { ATPase subunit alpha-1 }\end{array}$ & Atp1a1 & $\mathrm{H}(1) \mathrm{M}(1) \mathrm{R}(1)$ & 89 \\
\hline MetI; MetII & P04797 & $\begin{array}{l}\text { Glyceraldehyde-3-phosphate } \\
\text { dehydrogenase }\end{array}$ & Gapdh & $\mathrm{H}(1) \mathrm{M}(1) \mathrm{R}(1)$ & 88 \\
\hline MetI; MetII & P54311 & Transducin beta-1 & Gnb1 & $\mathrm{H}$ (3) M (3) R (3) & 87 \\
\hline MetI & Q07936 & Annexin A2 & Anxa2 & $\mathrm{H}(1) \mathrm{M}$ (3) R (3) & 86 \\
\hline MetI; MetII & P04897 & $\begin{array}{l}\text { Guanine nucleotide-binding } \\
\text { protein G(i) subunit alpha-2 }\end{array}$ & Gnai2 & $\mathrm{H}$ (3) M (3) R (3) & 86 \\
\hline MetI; MetII & P06761 & $\begin{array}{l}\text { Endoplasmic reticulum chaperone } \\
\mathrm{BiP}\end{array}$ & Hspa5 & $\mathrm{H}(1) \mathrm{M}(1) \mathrm{R}(1)$ & 86 \\
\hline MetI; MetII & P35565 & Calnexin & Canx & $\mathrm{H}(1) \mathrm{M}(1) \mathrm{R}(1)$ & 83 \\
\hline MetI; MetII & G3V6P7 & Myosin heavy chain 9 & Myh9 & $\mathrm{H}(3) \mathrm{M}(3)$ & 83 \\
\hline MetI & P31000 & Vimentin & Vim & $\mathrm{H}(3) \mathrm{M}(3) \mathrm{R}(3)$ & 81 \\
\hline MetI; MetII & P09527 & Ras-related protein Rab-7a & Rab7a & $\mathrm{H}(1) \mathrm{M}(1) \mathrm{R}(1)$ & 79 \\
\hline MetI; MetII & P26453 & Basigin & Bsg & $\mathrm{H}(3) \mathrm{M}(3) \mathrm{R}(3)$ & 78 \\
\hline MetI; MetII & D4A133 & $\begin{array}{l}\text { V-type proton ATPase catalytic } \\
\text { subunit A }\end{array}$ & Atp6v1a & $\mathrm{H}(3) \mathrm{M}(3)$ & 78 \\
\hline MetI; MetII & P63102 & 14-3-3 protein zeta/delta & Ywhaz & $\mathrm{H}(1) \mathrm{M}(1) \mathrm{R}(1)$ & 77 \\
\hline MetI; MetII & P11442 & Clathrin heavy chain 1 & Cltc & $\mathrm{H}(3) \mathrm{M}(3) \mathrm{R}(3)$ & 77 \\
\hline MetII & F1M779 & Clathrin heavy chain & Cltc & $\mathrm{H}$ (3) M (3) R (3) & 77 \\
\hline MetII & Q5XI04 & $\begin{array}{l}\text { Erythrocyte band } 7 \text { integral } \\
\text { membrane protein }\end{array}$ & Stom & $\mathrm{H}(1) \mathrm{M}(1)$ & 77 \\
\hline MetI; MetII & P54313 & Transducin beta- 2 & Gnb2 & H (3) M (3) R (3) & 76 \\
\hline MetII & B5DEH2 & Erlin-2 & Erlin2 & H (3) M (3) R (3) & 74 \\
\hline MetII & O70377 & $\begin{array}{l}\text { Synaptosomal-associated protein } \\
23 \text { (SNAP-23) }\end{array}$ & Snap23 & $\mathrm{H}(3) \mathrm{M}(3) \mathrm{R}(3)$ & 74 \\
\hline MetI; MetII & P32551 & $\begin{array}{l}\text { Cytochrome b-c1 complex subunit } \\
2 \text { mitochondrial }\end{array}$ & Uqcrc2 & H (3) M (3) R (3) & 72 \\
\hline MetI; MetII & Q5XIH7 & Prohibitin 2 & $\mathrm{Phb} 2$ & $\mathrm{H}(3) \mathrm{M}(3) \mathrm{R}(3)$ & 71 \\
\hline \multicolumn{6}{|c|}{$\begin{array}{l}\text { Method-Post-isolation treatment method; Protein accession-UniProt protein accession number; Protein } \\
\text { description-Functional description; Gene name-Name of gene that codes for the protein sequence; Experimental } \\
\text { evidence-Experimental data validating inclusion as a lipid raft protein; (1) indicates protein identification by more } \\
\text { than one biochemical extraction method; (3) indicates fulfillment of criteria (1) and the sensitivity to more than } \\
\text { one raft perturbation technique; Number of citations-Number of studies with supporting experimental evidence } \\
\text { describing the lipid raft protein; H-Human; M-Mouse; R-Rat. }\end{array}$} \\
\hline
\end{tabular}


Proteins with transmembrane domains are also known to be targeted to lipid rafts $[47,48]$. The presence of a transmembrane domain was predicted in all proteins identified by both methods using TMHMM server version 2.0 (Figure 4A,B). The common group of proteins contained a sizeable number of proteins with transmembrane domains $(27 \% ; 63 / 233)$. Few $(7.14 \% ; 14 / 196)$ unique proteins in MetI had transmembrane domains, and only four of these unique proteins had two or more transmembrane domains. In contrast, the majority $(52 \% ; 274 / 520)$ of the unique proteins obtained using MetII contained at least one transmembrane domain. Furthermore, the unique proteins isolated by MetII had a higher number of transmembrane domain/protein in comparison to the common proteins or unique proteins identified with MetI. Thus, MetII was more efficient at extracting proteins with transmembrane domains.

A

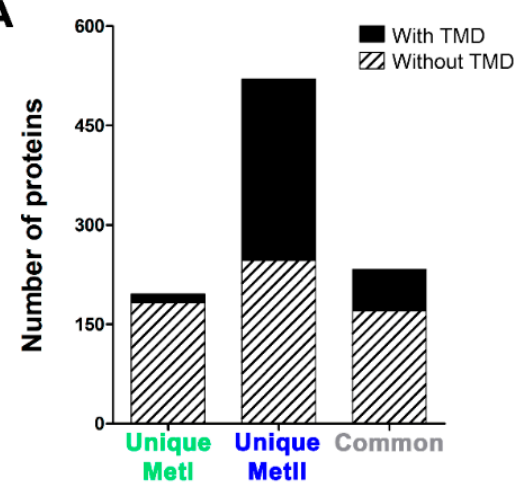

B

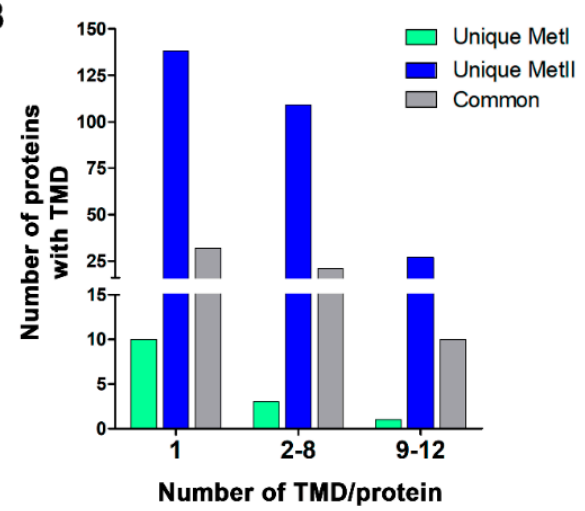

Figure 4. Analysis of transmembrane domain (TMD) present in unique and common mast cell lipid raft proteins identified using Method I or Method II. Prediction of the presence of TMD was done using the TMHMM server v2.0. (A) Number of proteins with and without TMDs is shown. (B) The number of proteins with TMD versus the number of TMD/protein is given.

\subsection{Functional Characterization of Mast Cell Lipid Raft Proteome}

Initially, all identified proteins from both MetI and MetII were used for global proteomic analysis. The 949 proteins were annotated according to the three classes of biological domains (cellular component, biological processes, and molecular function) from Gene Ontology (GO) using the Software Tool for Researching Annotations of Proteins (STRAP) [49]. In the cellular component class, $13 \%$ of the proteins were associated with the GO terms plasma membrane (11\%) and cell surface ( $2 \%)$. Terms associated with cytoplasm $(10 \%)$, other intracellular organelles $(11 \%)$, endoplasmic reticulum $(9 \%)$, mitochondria $(6 \%)$, and cytoskeleton (5\%) were also highly represented (Figure 5A). In the GO class biological processes, the largest groups were proteins categorized by their involvement in regulation $(26 \%)$ and cellular process $(24 \%)$. The terms localization $(13 \%)$ and response to stimulus $(10 \%)$ were also highly represented (Figure 5B). Finally, in the molecular function class, the GO terms binding (48\%), catalytic activity $(30 \%)$, and structural molecular activity ( $8 \%$ ) were the most frequent (Figure 5C). 
A

CELLULAR COMPONENT

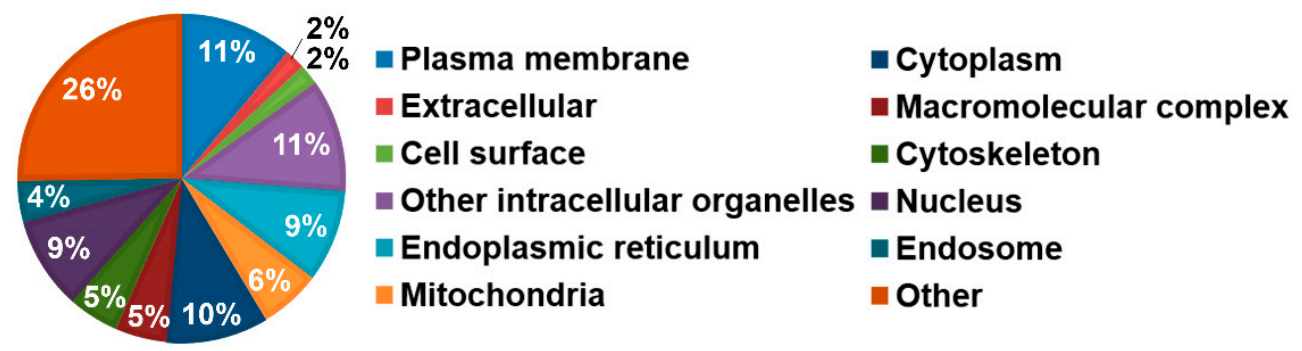

B

BIOLOGICAL PROCESSES

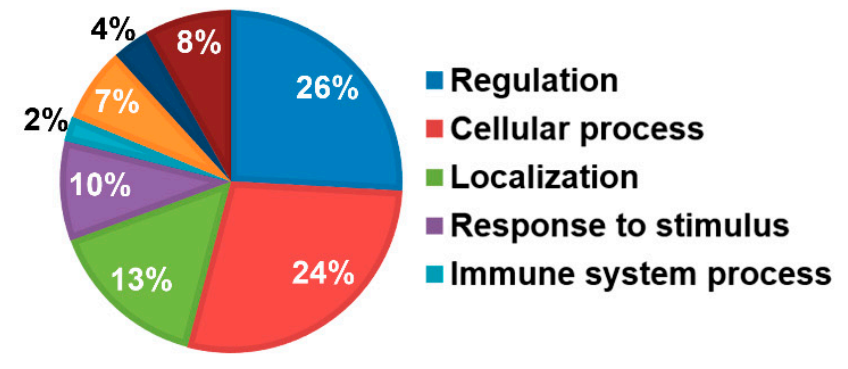

Interaction with cells

- Metabolic process

- Developmental process

n Other

MOLECULAR FUNCTION

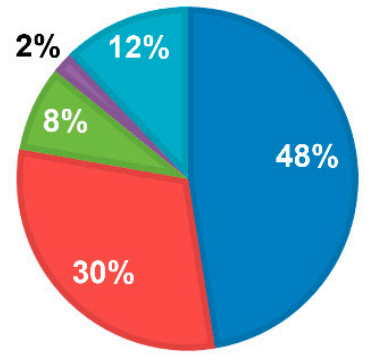

- Binding

- Catalytic activity

- Molecular transducer activity

mother

nStructural molecular activity

Figure 5. Graphical representation of the GO classes of biological domains association data with the 949 proteins identified in mast cell lipid rafts as annotated by STRAP. Identified proteins were grouped according to the three main GO classes: (A) cellular component, (B) biological processes, and (C) molecular function. The data is expressed as a percentage of proteins associated with each GO term.

2.5. Distribution among GO Domains of the Mast Cell Lipid Raft Proteins Identified Using Different Post-Isolation Methods

In order to evaluate the differences between the methods, the identified proteins were divided into unique groups for each method and the common group. The proteins were analyzed according to the three classes of biological domains from GO by STRAP [49]. In the GO cellular component class, the unique MetI proteins had a higher percentage of proteins linked to the GO terms: cytoplasm, nucleus, and other. The unique MetII proteins had a higher percentage in cytoplasm, endoplasmic reticulum, other, other intracellular organelles, and plasma membrane. Moreover, the comparison between the methods showed an approximately 1.2-2.5-fold increase in unique MetII proteins linked to the terms endoplasmic reticulum, endosome, other, other intracellular organelles, and plasma membrane. The common group showed a high percentage of proteins associated with the terms nucleus, other, and plasma membrane (Figure 6A). The MetII unique proteins were distributed in practically all the terms in the cellular component in GO. The distribution of the MetII unique proteins with transmembrane domains was practically identical (Figure S3: Total identified proteins and unique MetII proteins with transmembrane domains (TMD) have a similar distribution in the cellular component GO class). In 
the biological processes GO class, there was an increased percentage of unique proteins from MetI associated with the terms cellular process, other, regulation, and response to stimulus. With MetII the highest percentage of proteins were associated with the terms cellular process, localization, other, and regulation. Among the common proteins, the highest percentage of proteins were associated with the terms cellular process, localization, other, regulation, and response to stimulus (Figure 6B). In the molecular function class, there was an increased percentage of unique proteins isolated with MetI associated with the terms binding, catalytic activity, and other. With MetII, the highest percentage of proteins were associated with the terms binding, catalytic activity, and other. In the common group, the highest percentage of proteins was associated with the terms binding, catalytic activity, and other (Figure 6C). The identified proteins were also analyzed by the highest percentage within each term (Table 2). These analyses demonstrate that functionally, the identified proteins were consistent with their being lipid raft components. Moreover, there was no bias between MetI or MetII as each method was associated with $10 \mathrm{GO}$ terms and the common proteins were associated with $8 \mathrm{GO}$ terms. However, the highest percent of proteins associated with a given GO term differed between the methods.
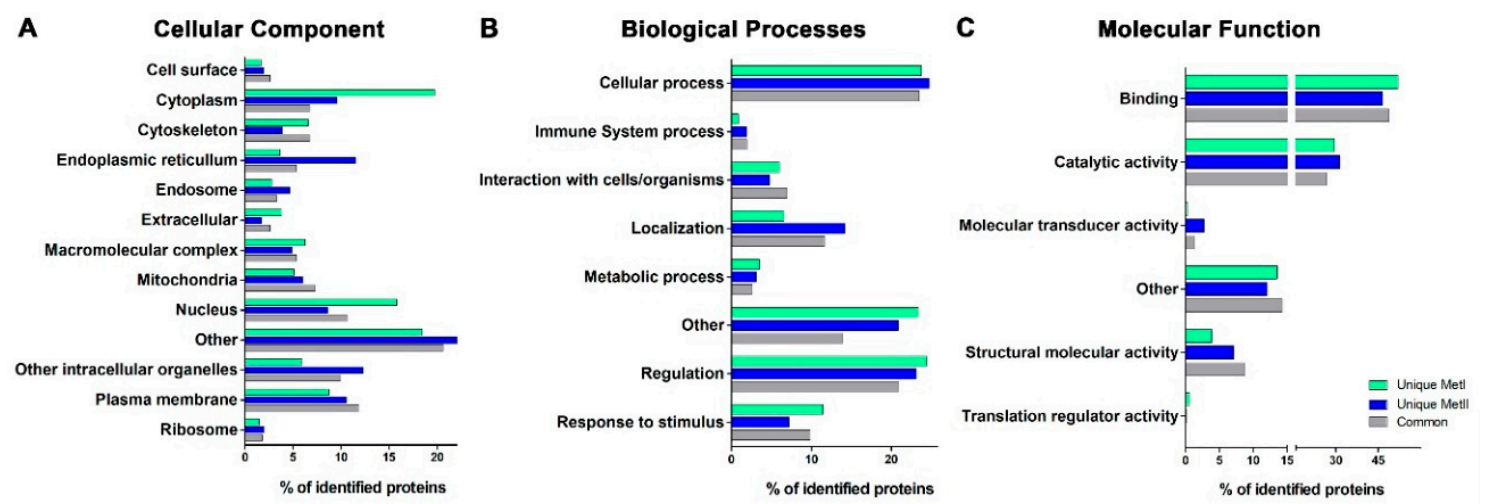

Figure 6. Analysis of unique and common proteins localized in mast cell lipid rafts isolated with MetI or MetII. The unique and common proteins identified using MetI and MetII in lipid rafts from RBL-2H3 MCs were analyzed according to the three main GO classes: (A) cellular component, (B) biological processes, and (C) molecular function. Data for the unique and common proteins identified using MetI and MetII in lipid rafts from RBL-2H3 MCs was annotated using STRAP.

\subsection{Functional Enrichment of the Mast Cell Lipid Raft Proteins}

It is also important in proteomic studies to provide a functional assessment of the identified proteins for further system studies. Therefore, the functional relationship among the proteins identified in the MC lipid raft proteome was assessed. An analysis was carried out using the data from Rattus norvegicus proteins available in the DAVID Bioinformatics Resources database [50]. Many functional groups were identified in this proteome data. These groups were based on the enrichment score, the number of annotated proteins in each GO term, Fisher exact $p$-value, and false discovery rate (FDR) (Table S6: Enriched GO terms from mast cell lipid raft proteome analysis using DAVID Bioinformatic Resources). The groups with higher enrichment scores are shown in Figure 7. The terms associated with the highest group enrichment score were extracellular vesicle, extracellular exosome, membrane-bound vesicle, and extracellular regions; these terms are all consistent with a localization on or near the plasma membrane. However, the group with the highest fold enrichment was associated with the terms mast cell degranulation, leukocyte degranulation, and MC activation involved in immune response. Other significantly enriched single terms that were not grouped were membrane protein complex, membrane organization, membrane-bounded organelle, cytoskeleton organization, and biological adhesion (Figure 7). This analysis showed that based on the terms encompassed in the enriched groups, as well as the isolated terms, that proteins associated with processes such as vesicle-mediated secretion by immune cells, membrane associated protein localization and stabilization, and immune cell signaling response were significantly enriched in the MC lipid raft proteome. 
Table 2. Highest percentage of annotated proteins within each GO term.

\begin{tabular}{|c|c|c|c|}
\hline GO Term & Unique MetI & Unique MetII & Common \\
\hline \multicolumn{4}{|c|}{ Cellular Component Class } \\
\hline Cell surface & & & + \\
\hline Cytoplasm & + & & \\
\hline Cytoskeleton & + & & + \\
\hline Endoplasmic reticulum & & + & \\
\hline Endosome & & + & \\
\hline Extracellular & + & & \\
\hline Macromolecular complex & + & & \\
\hline Mitochondria & & & + \\
\hline Nucleus & + & & \\
\hline Other & & + & \\
\hline Other intracellular organelles & & + & \\
\hline Plasma membrane & & & + \\
\hline Ribosomes & & + & \\
\hline \multicolumn{4}{|c|}{ Biological Processes Class } \\
\hline Cellular process & & + & \\
\hline Immune system process & & + & + \\
\hline Interaction with cells/organelles & & & + \\
\hline Localization & & + & \\
\hline Metabolic process & + & & \\
\hline Other & + & & \\
\hline Regulation & + & & \\
\hline Response to stimulus & + & & \\
\hline \multicolumn{4}{|c|}{ Molecular Function Class } \\
\hline Binding & + & & \\
\hline Catalytic activity & & + & \\
\hline Molecular transducer activity & & + & \\
\hline Other & & & + \\
\hline Structural molecular activity & & & + \\
\hline
\end{tabular}




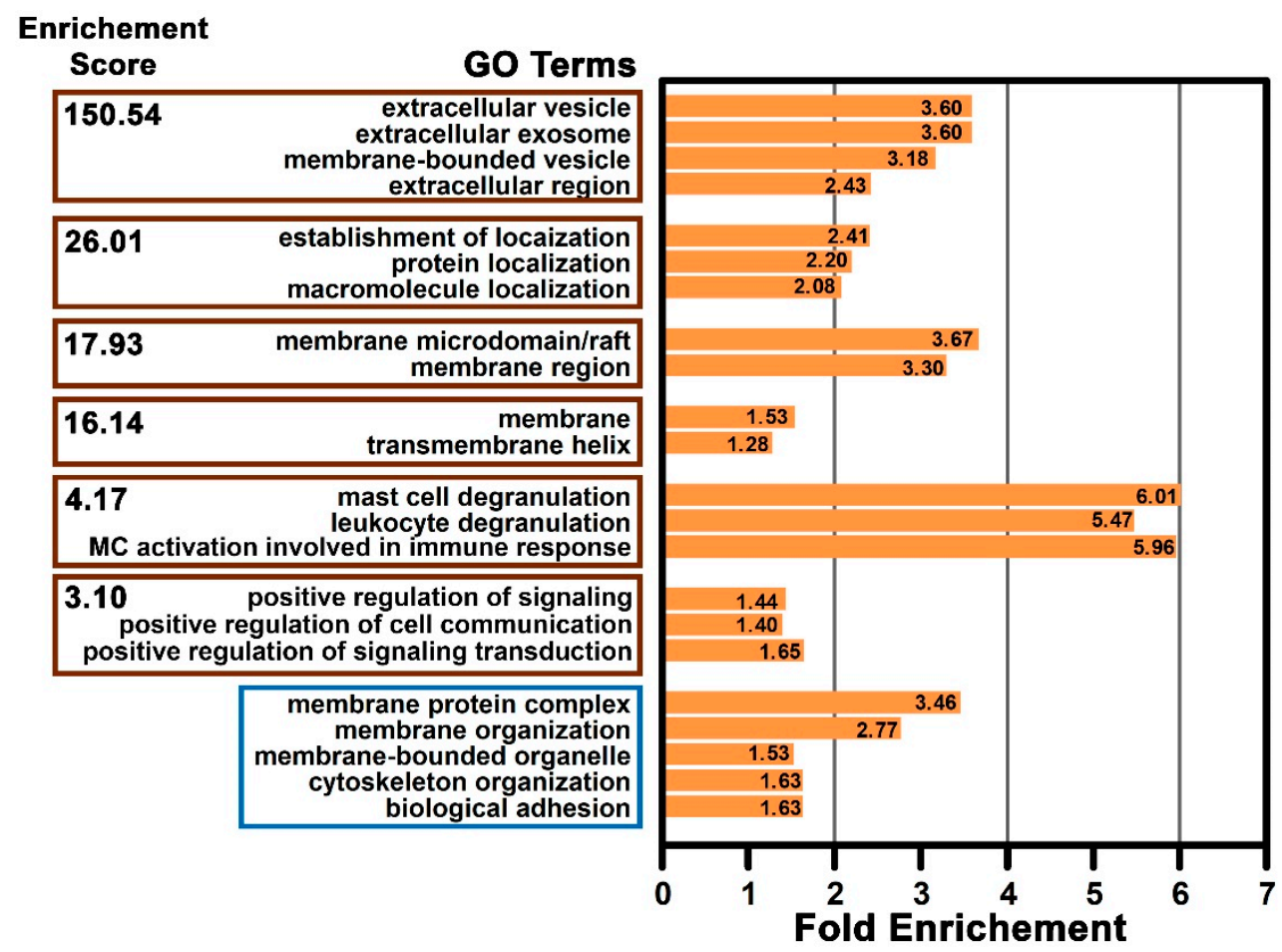

Figure 7. Functional relationship among the proteins and their associated GO terms in the mast cell lipid raft proteome. Groups with the highest enrichment scores following analysis using DAVID are shown. The enrichment score groups (brown rectangles) and non-grouped terms (blue rectangle) are indicated according to their biological significance. The fold enrichment factor (orange bars) is also shown. Data was analyzed using the DAVID Bioinformatics Resources database.

\section{Discussion}

This proteomic study provides a comprehensive description of the protein composition of RBL-2H3 $\mathrm{MC}$ lipid rafts. It provides evidence that the use of two methods to extract lipid raft proteins increases the proteome coverage and improves the identification of integral and associated lipid raft proteins. These proteins are involved in various aspects of MC function, especially those related to MC secretion, organization and stabilization of macromolecules complexes, and signal transduction.

Although the structure, composition, and functional roles of lipid rafts has been extensively investigated in many cell types, there is no universal protocol for the isolation and enrichment of these microdomains [24-26]. The lack of a universal protocol for lipid raft isolation stems from the controversy over the biochemical aspects of raft microdomains, such as their instability, size, and highly dynamic nature $[2,51,52]$. However, the solubilization of whole samples with nonionic mild detergents, such as Triton X-100 at low temperature, followed by sucrose density gradient centrifugation and the recovery of the detergent resistant membranes (DRMs) from the light fractions of the gradient, is the most commonly used method to obtain lipid rafts $[13,18,22,51,53-55]$. This method requires careful interpretation, since differences in lipid raft isolation methods, such as type and concentration of the detergent, as well as the duration of the incubation, make results difficult to compare $[21,56]$. Moreover, evidence suggest that microdomain fractions obtained using detergent-free methods are less enriched in lipid raft proteins than those prepared with detergents [57].

The proteins found in the low-density fractions may be integral lipid raft constituents or associated with lipid raft components $[23,44,47,48,58]$. Some of these proteins, such as LAT1, are known to be lipid raft components and serve as a guide to elucidate the contents and properties of these microdomains $[23,43,44]$. Using LAT1 as a marker, the identification of lipid rafts in the low-density fractions of the sucrose gradient seen here is supported by previous results in RBL-2H3 MCs [6,59-62] and in bone marrow-derived MCs (BMMCs) [63]. However, in other cell types, other proteins, such 
as caveolin-1 [64,65], flotillin-1 [64,66,67], and CD-36 [56], are often used to identify lipid rafts. The findings seen here, as well as those reported in the literature, confirm that Fractions 2 and 3 from RBL-2H3 MC homogenates are enriched in lipid rafts, and that these fractions may be pooled and used for proteomic characterization.

Numerous other studies have examined the lipid raft proteome in various cell types and tissues and form the basis of the RaftProtV2 database [25]. The RaftProtV2 database has been used to compare proteomic data from previous studies with newly reported lipid raft proteomes. Other investigations have described a similar percentage of proteins already annotated in the RaftProtV2 database as was seen in the present study $[12,13,68,69]$. Furthermore, it has been suggested that less than $25 \%$ of the total reported membrane raft proteins in the RafProtV2 database fall into the high confidence category [25]. However, in the lipid raft proteome reported in this study, $65 \%$ of the proteins were high confidence raft proteins, indicating that the obtention and post-isolations methods used in this study resulted in an enriched lipid rafts fraction from MCs.

Part of the proteins identified in the present investigation had not been annotated in the RaftProtV2 database. However, some of the non-annotated proteins belonged to the same family of proteins as known lipid raft proteins. For example, although FceRI subunit beta is absent from the RaftProtV2 database, the gamma subunit of the receptor is included [56,70]. The current study confirmed the presence of the FceRI subunit beta in MC lipid rafts using proteomic and immuno-blot analysis. FceRI subunit beta had previously been reported as a component of MC lipid rafts using western blots and immunomicroscopy $[6,62,63]$. Since the RaftProtV2 database does not contain any MC proteomes, not surprisingly, many of the RaftProtV2 non-annotated proteins are mainly expressed by MCs such as chymase, FceRI subunit beta, mast cell carboxypeptidase A, and mast/stem cell growth factor receptor. Other non-annotated proteins are expressed by MCs and other immune cells, including arachidonate 5-lipoxygenase-activating protein, MHC class I, SAMNS1, macrophage stimulating 1 receptor, and interleukin-3 receptor subunit beta [71,72].

The use of more than one method to extract proteins from the lipid raft fractions may yield a more complete recovery of proteins [25]. Both MetI and MetII have been used extensively in other studies characterizing lipid raft proteomes from different tissues and cell types $[1,3,12,14,73,74]$. In the present study, extraction of proteins from the lipid raft fractions using MetI or MetII resulted in the identification of proteins common to both methods, as well as proteins unique to each method. The differences observed between MetI and MetII may be explained, in part, by the distinct post-isolation treatment used in each method. The strategy applied in MetI eliminates the sucrose from the enriched lipid raft fractions prior to MS analysis [16]. The procedure used in MetII mixes the sample with another detergent (OGP), followed by methanol-chloroform extraction, which aids in removing the interfering lipids that could be aggregated with the isolated proteins [73,74]. Extraction using MetII yielded a higher number of total proteins, as well as those with lipid modifications typical of membrane raft proteins [1,47].

Lipid modifications can be either permanent cotranslational additions or post-translational modifications $[47,48]$. The main lipid modifications are S-palmitoylation, isoprenylation, N-terminal myristic acid tails, GPI-anchors, and cysteine acylation. Conjugation to lipids seems to be the most widespread and consistent factor in determining whether a protein will partition into lipid rafts $[47,75]$. Moreover, the isolation and identification of transmembrane proteins represents one of the most difficult challenges for MS [25]. However, extraction with chloroform/methanol used in MetII greatly improved the yield of the predicted transmembrane proteins. Transmembrane domains typically consist of $\alpha$-helices or $\beta$-sheets, which favor the entry of the proteins into membrane rafts [48,76]. MetII was more efficient in extracting proteins with lipid modification or transmembrane domains and is thus more suited toward providing MC lipid raft proteins for MS investigations. The post-isolation treatment used in MetII may expose a greater number of transmembrane proteins, thus making them available for trypsin digestion [74] and allowing for their subsequent MS identification. 
The importance of proteomic studies goes beyond a simple catalogue of the proteins present in a given sample. It also provides information on the functional relationships among the identified proteins. The Gene Ontology (GO) project provides for consistent descriptions of gene products found in different databases. The association of the lipid raft proteins with the GO class biological processes and molecular function showed that the MC lipid raft proteins are associated with terms consistent with the central role of lipid rafts in a number of important cellular events. The terms such as cellular process and catalytic activity can be correlated with the function of lipid rafts in protein processing [77]. Moreover, the terms structural molecular activity, binding, and localization can be related to intracellular trafficking and sorting mechanisms [78,79]. Additionally, the terms regulation and response to stimulus integrate the function of lipid rafts in diverse signal transduction pathways $[6,7,32,80]$.

In the analysis of the GO class cellular component, the proteins associated with terms other than plasma membrane may be explained in part by the fact that many proteins originally located in the cytoplasm or nucleus could be translocated and interact with plasma membrane constituents to form protein complexes [81]. Moreover, lipid rafts may also be found in cellular compartments other than the plasma membrane such as in endoplasmic reticulum and mitochondria $[55,74,82-84]$. Several lipids and proteins associated with lipid rafts are synthesized in the endoplasmic reticulum/Golgi apparatus before being transported to the plasma membrane [27], where they may move laterally within the plasma membrane as well as traffic continuously between the plasma membrane and internal compartments [78]. Finally, nuclear lipid microdomains are important in maintaining subnuclear structures and act as platforms for the transcription process during proliferation [85].

In addition, within the cellular component class, five percent of the identified proteins were associated with the GO term cytoskeleton. The structure and organization of lipid rafts is tightly integrated with the cell cytoskeleton $[7,13,19,62]$. Studies using live cell imaging have shown that the actin filaments are commonly co-localized with lipid rafts under a stimulus induced co-redistribution of raft components at the cell surface [86]. Moreover, the dynamic rearrangement of the cytoskeleton in MCs following stimulation can act to stabilize the lipid raft clusters $[6,62,87,88]$.

The group with the highest enrichment score in the MC lipid raft proteome included the GO terms extracellular vesicle, membrane-bounded vesicle, extracellular exosome, and extracellular region. The terms that showed the greatest fold enrichment factor included the terms mast cell degranulation, leukocyte degranulation, and MC activation involved in immune response. Lipid rafts have ideal features for participating in intracellular membrane transport, acting as a crucial regulator of vesicle cargo and their consequent endocytosis and secretion [89-91]. Notably, the hallmark of MC activation via $F_{c \varepsilon R I}$ is the immediate release via highly regulated exocytosis (degranulation) of inflammatory mediators that are presynthesized and stored in MC secretory granules [92,93]. Moreover, perturbation of the raft structure has a profound impact on FceRI-mediated degranulation in MCs $[6,62,94]$.

The group with the next-highest enrichment score included proteins that were involved with the establishment of localization, protein localization, and macromolecular localization. Many of the proteins associated with these terms are adaptors or scaffolding proteins. These proteins then act as docking sites for signaling molecules in lipid raft domains forming a multicomponent assembly, which facilitates signal transduction in diverse pathways $[88,95]$. Furthermore, other raft proteins identified in this study were also related to the signal transduction pathways in MCs. These proteins included CD45 (receptor-type tyrosine-protein phosphatase C), Fc $\gamma$ RII (low affinity immunoglobulin Fc gamma receptor II), MC/stem cell growth factor receptor, $\mathrm{IP}_{3}$-receptor, integrins, phospholipid scramblase, serine/threonine-protein phosphatase PP1-alpha, protein-tyrosine phosphatase 1B, IQGAP1, calreticulin, calmodulin, DJ-1, RhoA, Gnai-2, and cdc42 [96-102].

Another group with highly enriched scores included the GO terms membrane microdomain/raft and membrane region. Several transmembrane proteins, known to be associated with lipid rafts, were also identified in our MC proteome such as the flotillins and prohibitins. Other scaffold proteins, such as tetraspanins (CD81 and CD63) and the important transmembrane adaptor proteins 
(TRAPs) in immunoreceptor signaling LAT1 and NTAL (non-T cell activation linker; LAT2) [103], were also identified in this lipid raft proteome. LAT1 and NTAL become rapidly phosphorylated in FceRI-activation, resulting in its association with numerous signaling molecules [32,43,104]. Moreover, these TRAPs are also involved in the regulation of MC morphology, adhesion, and chemotaxis [104,105]. RACK1 (receptor for activated C kinase 1), a member of the tryptophan-aspartate repeat family of proteins, was also identified. RACK1 adopts a highly conserved seven-bladed $\beta$-propeller structure that serves as binding sites for multiple partners [106,107]. Recently, RACK1 was identified as a crucial component of a multiprotein complex formed in T-cell lipid rafts upon TCR (T-cell antigen receptor) activation [108]. Despite the significant role that RACK1 plays in shuttling and anchoring proteins and its involvement in immunoregulatory responses [107-109], RACK1 has not previously been described in MCs.

There was also an increased enrichment score of the group containing the GO terms MC degranulation, leukocyte degranulation, and MC activation involved in immune response. This group also showed the highest fold enrichment. This MC lipid raft proteome consistently identified many of the proteins already described to be involved in MC degranulation, such as SNAREs (soluble N-ethylmaleimide-sensitive-factor attachment protein receptor), including VAMP (vesicle-associated membrane protein) 7 [110], VAMP3, VAMP8 [110,111], SNAP-23 (synaptosomal-associated protein 23) [110,112], Syntaxin 3 [113], and Syntaxin 4 [113]. In addition to the accessory proteins the RAB GTPases (RAB3D, RAB5, RAB7, RAB9A, RAB11, RAB27A, RAB27B, and RAB43) [114-116], syntaxin-binding protein 2 (MUC18-2) [113], $\alpha$-SNAP (alpha-soluble NSF attachment protein) [93], and syntaxin-binding protein 5 (Tomosyn-1) [117] were also identified.

The functionally related group that includes the GO terms positive regulation of signaling, positive regulation of cell communication, positive regulation of signal transduction was also enriched. Cell membrane lipids and lipid raft proteins have been implicated in various signaling events, including those dependent on the immunoglobulin-receptor superfamily in immune cells $[18,32,80,118]$. In MCs, the events immediately following FcERI activation that result in downstream signaling are still not completely understood $[32,87,92]$. However, it is known that the aggregated receptors are translocated into lipid rafts where the SFKs are activated with subsequent phosphorylation of the receptor subunits $[32,87,88]$. The $\mathrm{N}$-terminal sequences of SFKs allow them to anchor to saturated fatty acid derivatives in the inner leaflet of the plasma membrane, enabling their partitioning into lipid rafts $[119,120]$. Five of the eight members of SFKs, including Lyn, Fyn, Yes, Fgr, and Lck, were identified in this lipid raft proteome from non-activated RBL-2H3 MCs.

\section{Conclusions}

Based on the present data, a comprehensive study of the MC lipid raft proteome provides strong evidence that our two methods increased the proteome coverage and improved the identification of integral and associated lipid raft proteins. These proteins are involved in various aspects of MC function, especially those related to MC regulated secretion, organization and stabilization of macromolecules complexes, and signal transduction pathways. Thus, this identification of the raft membrane proteins could provide important tools for further investigation of molecular mechanisms related to the immunoregulatory functions of MCs.

\section{Materials and Methods}

\subsection{Cell Culture}

RBL-2H3, a rat MC line [42], was grown as monolayers in Dulbecco's Minimum Essential Medium (DMEM) supplemented with $15 \%$ fetal calf serum and an antibiotic-antimycotic mixture $(100 \mathrm{U} / \mathrm{mL}$ penicillin, $100 \mu \mathrm{g} / \mathrm{mL}$ streptomycin, and $0.25 \mu \mathrm{g} / \mathrm{mL}$ amphotericin B) in a humidified environment containing $5 \% \mathrm{CO}_{2}$ in air at $37{ }^{\circ} \mathrm{C}$. All reagents used for the cell culture were purchased from ThermoFisher Scientific (Thermo Fisher Scientific, Invitrogen, Carlsbad, CA, USA). 


\subsection{Isolation of Lipid Rafts from RBL-2H3 Mast Cells}

The lipid rafts were isolated using sucrose density-gradient ultracentrifugation, essentially as previously described [120]. Briefly, (3-5) $\times 10^{7}$ RBL-2H3 MCs were plated in $150 \mathrm{~mm}$ tissue culture dishes (Corning Incorporated - Life Sciences, Oneonta, NY, USA). After $24 \mathrm{~h}$, the cells were washed twice with ice-cold PBS and harvested and lysed on ice with $0.05 \%$ Triton X-100 (v/v) in $2.6 \mathrm{~mL}$ ice-cold MES buffer (25 mM 2-(4-Morpholino) ethane sulfonic acid, pH 6.5, $150 \mathrm{mM} \mathrm{NaCl}, 5 \mathrm{mM}$ EDTA, and $1 \mathrm{mM} \mathrm{Na}_{3} \mathrm{VO}_{4}$ ) containing $2 \mathrm{mM}$ PMSF and $50 \mu \mathrm{L} / \mathrm{mL}$ protease inhibitor cocktail. All reagents were purchased from Millipore Sigma (St. Louis, MO, USA). The resulting suspension was then homogenized 30 times on ice using a Dounce homogenizer with a tight-fitting piston, followed by incubation on ice for $15 \mathrm{~min}$. The lysates were then centrifuged for $10 \mathrm{~min}$ at $900 \times \mathrm{g}$ and the $2.6 \mathrm{~mL}$ of supernatant was overlaid on $2.6 \mathrm{~mL} 80 \%$ sucrose $(w / v)$ in a MES buffer in the bottom of a $13 \mathrm{~mL}$ Beckman centrifuge tube (Beckman Coulter, Fullerton, CA, USA) and gently vortexed to give the final concentration of $40 \%$ sucrose. Thereafter, the sample was overlaid with $5.2 \mathrm{~mL}$ of $35 \%$ sucrose $(w / v)$ in lysis buffer. Then, $2.6 \mathrm{~mL} 5 \%$ sucrose $(w / v)$ in lysis buffer was added on top to form a discontinuous gradient. Samples were centrifuged using a Beckman SW40Ti rotor (Beckman Coulter) at 38,000 rpm for $20 \mathrm{~h}$ at $4{ }^{\circ} \mathrm{C}$. Fractions $1.3 \mathrm{~mL}$ in volume were collected from the top of the tube.

\subsection{Immunoblotting Analysis of Lipid Raft Enriched Fractions}

In order to localize the lipid rafts in the gradient fractions, $5 \mu \mathrm{L}$ from each fraction were immobilized on Hybond membranes (GE Healthcare Life Sciences, Marlborough, MA, USA) using the vacuum microfiltration system Bio Dot (Bio-Rad Laboratories, Inc., Hercules, CA, USA). The membranes were immunoblotted as previously described [121]. The following primary antibodies were used: goat polyclonal antibody anti-mouse LAT (Clone Q-20) (Santa Cruz Biotechnology Inc., Santa Cruz, CA, USA), rabbit polyclonal antibody anti-human Lyn (Clone 44 sc-15) (Santa Cruz Biotechnology Inc.), mouse $\mathrm{mAb}$ anti-FceRI beta subunit antibodies generously provided by Dr. Reuben Siraganian (NIH—NIDCR, Bethesda, MD, USA), rabbit polyclonal antibody anti-human Flotillin-1 (ab41927) and rabbit polyclonal antibody anti-human Histone H3 (ab1791) (Abcam, Cambridge, MA, USA), and mouse monoclonal antibody anti-rat GD1b derived gangliosides (Clone AR32AA4) (BD Pharmingen, San Jose, CA, USA). The secondary antibodies used were donkey anti-goat IgG conjugated to horseradish peroxidase (HRP), donkey anti-rabbit IgG conjugated to HRP, and donkey anti-mouse IgG conjugated to HRP (Jackson ImmunoResearch Laboratories Inc., West Grove, PA, USA). The membranes were developed using enhanced chemiluminescence (ECL Kit; GE Healthcare) and the images were obtained with ImageQuant LAS 4000 (GE Healthcare).

\subsection{Extraction and Digestion of Mast Cell Lipid Raft Proteins for Mass Spectrometry}

The lipid raft enriched fractions (the low-density Fractions 2 and 3) obtained from three independent experiments were pooled and the sample was used for two different post-isolation treatment methods. In MetI, the samples were mixed with ice-cold $50 \mathrm{mM} \mathrm{NH}_{4} \mathrm{HCO}_{3}$ (Millipore Sigma) pH 7.9, washed, and concentrated using an Amicon ${ }^{\circledR}$ Ultra-3 Centrifugal Filter (Merk Millipore, Burlington, MA, USA). In MetII, the pooled fractions were gently mixed with ice-cold MNE-buffer (25 mM MES, pH 6.5; $5 \mathrm{mM}$ EDTA; $150 \mathrm{mM} \mathrm{NaCl})$ and pelleted using centrifugation $(200,000 \times g, 1 \mathrm{~h})$. Samples were subsequently mixed with $100 \mu \mathrm{L}$ of $100 \mathrm{mM}$ n-octyl-beta-D-gluco-pyranoside (OGP) followed by methanol-chloroform extraction as previously described [74].

For both methods, the proteins were enzymatically digested as described previously $[122,123]$ with some modifications. Briefly, the protein content was quantified using the Bradford reagent (Millipore Sigma), and bovine serum albumin (BSA; Millipore Sigma) was used as a standard [124]. Then, $50 \mu \mathrm{g}$ of protein from each method was added to $10 \mathrm{~mL}$ of $50 \mathrm{mM}$ ammonium bicarbonate, $\mathrm{pH}$ 8.5. Then, $25 \mu \mathrm{L}$ of RapiGEST ${ }^{\mathrm{TM}}$ SF Surfactante $(0.2 \% v / v)$ (Waters, Milford, PA, USA) was added, and the sample was vortexed and then incubated at $80^{\circ} \mathrm{C}$ for $15 \mathrm{~min}$. The sample was reduced via incubation with $2.5 \mu \mathrm{L}$ 
of $100 \mathrm{mM}$ dithiothreitol (DTT) (GE Healthcare) at $60^{\circ} \mathrm{C}$ for $30 \mathrm{~min}$ and cysteine alkylation was done by incubating the samples with $2.5 \mu \mathrm{L}$ of $300 \mathrm{mM}$ iodocetamide (GE Healthcare) for $30 \mathrm{~min}$ at room temperature in the dark. The proteins were subsequently digested with $10 \mu \mathrm{L}$ of trypsin $(0.05 \mathrm{mg} / \mu \mathrm{L}$; Promega, Madison, WI, USA) at $37^{\circ} \mathrm{C}$ for $16 \mathrm{~h}$. The samples were subsequently acidified with $10 \mu \mathrm{L}$ of $5 \%$ trifluoracetic acid $(v / v)$ (Millipore Sigma), followed by incubation at $37^{\circ} \mathrm{C}$ for $90 \mathrm{~min}$ in order to stop the trypsin digestion and precipitate the RapiGEST ${ }^{\mathrm{TM}}$ SF Surfactante, and centrifugation at $21,000 \times g$ at $4{ }^{\circ} \mathrm{C}$ for $30 \mathrm{~min}$ was carried out. The supernatants were dried in a Savant ${ }^{\mathrm{TM}}$ SpeedVac ${ }^{\mathrm{TM}}$ Concentrator (ThermoFisher Scientific), and all obtained peptides were suspended in $49.5 \mu \mathrm{L}$ of a solution containing $20 \mathrm{mM}$ ammonium formate and $100 \mathrm{fmol} / \mu \mathrm{L}$ yeast enolase (MassPREP ${ }^{\mathrm{TM}}$ protein; Waters) as an internal standard.

\subsection{Nano-Electrospray Ionization Source (ESI) and Ultra-Performance Liquid Chromatography Mass Spectrometry $\left(U P L C-M S^{E}\right)$}

Nanoscale LC separation of tryptic peptides was performed using a nanoACQUITY ${ }^{\mathrm{TM}}$ system (Waters) equipped with a nanoEase ${ }^{\mathrm{TM}} 5 \mathrm{~mm} \times$ Bridge $^{\mathrm{TM}}$ BEH130 C18 $300 \mathrm{~mm} \times 50 \mathrm{~mm}$ precolumn; trap column $5 \mathrm{~mm}, 180 \mathrm{~mm} \times 20 \mathrm{~mm}$; and BEH130 C18 $1.7 \mathrm{~mm}, 100 \mathrm{~mm} \times 100 \mathrm{~mm}$ analytical reversed-phase column (Waters). The peptides were separated into 10 fractions and the gradient elution was performed as follows: $8.7,11.4,13.2,14.7,16,17.4,18.9,20.7,23.4$, and $65 \%$ acetonitrile $/ 0.1 \%$ $(v / v)$ formic acid, with a flow rate of $2000 \mathrm{~mL} / \mathrm{min}$. The source was operated in positive ionization mode nano-ESI $(+)$. GFP $[\mathrm{Glu}]^{1}$-fibrinopeptide B human $\left([\mathrm{MC} 2 \mathrm{H}]^{2+}=785.8426\right)$ (Millipore Sigma) was used for lock mass calibration of the apparatus, using a constant flow rate of $0.5 \mu \mathrm{L} / \mathrm{min}$ at a concentration of $200 \mathrm{fmol}$ protein. MS analysis was performed on a Synapt G1 MS ${ }^{\mathrm{TM}}$ (Waters) equipped with a NanoElectronSpray source and two mass analyzers: a quadrupole and a time-of-flight (TOF) operating in V-mode. The mass spectrometer was programmed in the data-dependent acquisition mode, in which a full scan in the $\mathrm{m} / \mathrm{z}$ region of 50-2000 was used. Data were obtained using the instrument in the $\mathrm{MS}^{\mathrm{E}}$ mode, which switched between the low energy $(6 \mathrm{~V})$ and elevated energy $(40 \mathrm{~V})$ acquisition modes every $0.4 \mathrm{~s}$. Samples were analyzed using three replicates.

\subsection{Data Processing and Protein Identification Analysis}

The acquired MS raw data were processed using the ProteinLynx Global Server version 2.4 (PLGS) (Waters). The data were subjected to automatic background subtraction, deisotoping, and charge state deconvolution. After processing, each ion comprised an exact mass-retention time (EMRT) that contained the retention time, intensity-weighted average charge, inferred molecular weight based on charge, and m/z. The processed spectra were searched against Rattus norvegicus entries $(29,952$ sequences) from the UniProt database (http://www.uniprot.org). The mass error tolerance for peptide identification was under $50 \mathrm{ppm}$. The parameters for protein identification included: (I) the detection of at least two fragment ions per peptide; (II) five fragments per protein; (III) the determination of at least one peptide per protein; (IV) carbamidomethylation of cysteine as a fixed modification; (V) phosphorylation of serine, threonine, and tyrosine, and oxidation of methionine were considered as variable modifications; (VI) maximum protein mass (600 kDa); (VII) one missed cleavage site was allowed for trypsin; (VIII) and a maximum false positive ratio (FDR) of $4 \%$ was allowed. The minimum repeat rate for each protein in all replicates was two. The protein table was compared using the Spotfire ${ }^{\circledR}$ v8.0 software, and graphs were generated for all data.

\subsection{Bioinformatics Analysis}

To detect the co-differentially presented protein in our data sets, we performed a comparative analysis of the overlaps using Venn diagrams (http://bioinformatics.psb.ugent.be/webtools/Venn/). RaftProtV2 database (http://raftprot.org) was used to systematically analyze the known lipid raft proteins [26]. Since proteomes of rat lipid rafts correspond to less than $13 \%$ of the included data [26], data obtained from human and mouse lipid raft proteomes was also used in this analysis. 
The graph of experimentally determined lipid modification types was generated using PhosphoSitePlus (http://www.phosphosite.org) [125]; SwissPalm (http://www.swisspalm.org) [126]; PRENbase (http://mendel.imp.ac.at/PrePS/PRENbase) [127]; MYRbase (http://mendel.imp.ac.at/ myristate/myrbase) [128]; and PredGPI (http://gpcr.biocomp.unibo.it/predgpi) [129]. In order to systematically investigate the denaturing properties of the applied methods, an analysis of potential transmembrane domains (TMD) was conducted using TMHMM 2.0 (http://www.cbs.dtu.dk/services/ TMHMM/) on the complete data set $[130,131]$.

Gene Ontology (GO) annotation charts based on the complete list of UniProt Knowledgebase accession entries were generated using STRAP (Software Tool for Researching Annotations of Proteins) [49]. The Database for Annotation Visualization and Integrated Discovery (DAVID; http://david.ncifcrf.gov), version 6.8, National Institute of Allergy and Infectious Diseases [50], was used for enrichment analysis, enrichment scores for annotation groups, and fold enrichment factors for individual GO terms, as well as Fisher's exact $p$-values and false discovery rates (FDR) using Benjamini-Hochberg coefficients, adjusting for multiple comparisons.

Supplementary Materials: Supplementary materials can be found at http://www.mdpi.com/1422-0067/20/16/3904/ s1. Figure S1: Dynamic range of the proteomic analysis. Figure S2: Immuno-blot analysis of the $\beta$-subunit of FceRI from RBL-2H3 MC lipid rafts. Figure S3: Total identified proteins and unique MetII proteins with transmembrane domains (TMD) have a similar distribution in the cellular component GO class. Table S1: Detailed annotation of proteins identified in Method I. Table S2: Detailed annotation of proteins identified in Method II. Table S3: Detailed annotation of proteins identified in Methods I and II. Table S4: Mast cell lipid raft proteins absent from RaftProtV2 database. Table S5: Mast cell lipid raft proteins analyzed by RafProtV2 database. Table S6: Enriched GO terms from mast cell lipid raft proteome analysis using DAVID Bioinformatic Resources.

Author Contributions: Conceptualization: E.G.F.F., C.O., and M.C.J.; Data Curation: E.G.F.F. and L.C.B.; Formal Analysis: E.G.F.F., L.C.B., L.A.M.J., C.L.B., C.O., and M.C.J.; Funding acquisition: C.O. and M.C.J.; Investigation: E.G.F.F., C.O., and M.C.J.; Methodology: E.G.F.F., L.C.B., C.L.B., C.O., and M.C.J.; Project administration: E.G.F.F. and M.C.J.; Resources: E.G.F.F., C.M.A.S., C.O., and M.C.J.; Supervision: C.O. and M.C.J.; Validation: E.G.F.F., L.A.M.J., and L.C.B.; Visualization: E.G.F.F., C.O., and M.C.J.; Writing-Original draft: E.G.F.F.; Writing-Review and editing: E.G.F.F., L.C.B., L.A.M.J., C.M.A.S., C.L.B., C.O., and M.C.J.

Funding: This work was supported by research grants from Fundação de Amparo à Pesquisa do Estado de São Paulo (FAPESP. www.fapesp.br; E.G.F.F.: 2013/12861-0; 2015/16673-0; M.C.J.: 2014/17671-8; 2017/14645-4; C.O.: 17/18618-1), Conselho Nacional de Desenvolvimento Científico e Tecnológico (CNPq, www.cnpq.br; M.C.J.: 304739/2015-4. C.O.: 304740/2015-2.

Acknowledgments: The authors thank Mariana Vieira Tomazett from Biological Science Institute, Federal University of Goiás, Samambaia Campus II, ICB2, for assistance with the preparation of samples for MS analysis.

Conflicts of Interest: The authors declare no conflict of interest. The funders had no role in the design of the study; in the collection, analyses, or interpretation of data; in the writing of the manuscript, or in the decision to publish the results.

\section{Abbreviations}

MC Mast cell

MetI Method I

MetII Method II

\section{References}

1. Pike, L.J. The challenge of lipid rafts. J. Lipid Res. 2009, 50, S323-S328. [CrossRef] [PubMed]

2. Simons, K.; Gerl, M.J. Revitalizing membrane rafts: New tools and insights. Nat. Rev. Mol. Cell Biol. 2010, 11, 688-699. [CrossRef] [PubMed]

3. Bieberich, E. Sphingolipids and lipid rafts: Novel concepts and methods of analysis. Chem. Phys. Lipids 2018, 216, 114-131. [CrossRef] [PubMed]

4. Enoki, T.A.; Heberle, F.A.; Feigenson, G.W. FRET Detects the Size of Nanodomains for Coexisting Liquid-Disordered and Liquid-Ordered Phases. Biophys. J. 2018, 114, 1921-1935. [CrossRef] [PubMed]

5. Sezgin, E. Super-resolution optical microscopy for studying membrane structure and dynamics. J. Phys. Condens. Matter 2017, 29, 273001. [CrossRef] 
6. Silveira, E.; Souza, A.M.; Mazucato, V.M.; Jamur, M.C.; Oliver, C. Lipid rafts in mast cell biology. J. Lipids 2011, 2011, 752906. [CrossRef] [PubMed]

7. Head, B.P.; Patel, H.H.; Insel, P.A. Interaction of membrane/lipid rafts with the cytoskeleton: Impact on signaling and function: Membrane/lipid rafts, mediators of cytoskeletal arrangement and cell signaling. Biochim. Biophys. Acta 2014, 1838, 532-545. [CrossRef]

8. Lingwood, D.; Simons, K. Lipid rafts as a membrane-organizing principle. Science 2010, 327, 46-50. [CrossRef]

9. Sezgin, E.; Levental, I.; Mayor, S.; Eggeling, C. The mystery of membrane organization: Composition, regulation and roles of lipid rafts. Nat. Rev. Mol. Cell Biol. 2017, 18, 361-374. [CrossRef]

10. Kusumi, A.; Suzuki, K. Toward understanding the dynamics of membrane-raft-based molecular interactions. Biochim. Biophys. Acta 2005, 1746, 234-251. [CrossRef]

11. Jia, J.Y.; Lamer, S.; Schümann, M.; Schmidt, M.R.; Krause, E.; Haucke, V. Quantitative proteomics analysis of detergent-resistant membranes from chemical synapses: Evidence for cholesterol as spatial organizer of synaptic vesicle cycling. Mol. Cell. Proteomics 2006, 5, 2060-2071. [CrossRef] [PubMed]

12. Liu, Y.; Yan, G.; Gao, M.; Zhang, X. Magnetic capture of polydopamine-encapsulated Hela cells for the analysis of cell surface proteins. J. Proteomics 2018, 172, 76-81. [CrossRef] [PubMed]

13. Shah, A.D.; Inder, K.L.; Shah, A.K.; Cristino, A.S.; McKie, A.B.; Gabra, H.; Davis, M.J.; Hill, M.M. Integrative Analysis of Subcellular Quantitative Proteomics Studies Reveals Functional Cytoskeleton Membrane-Lipid Raft Interactions in Cancer. J. Proteome Res. 2016, 15, 3451-3462. [CrossRef] [PubMed]

14. Feuk-Lagerstedt, E.; Movitz, C.; Pellmé, S.; Dahlgren, C.; Karlsson, A. Lipid raft proteome of the human neutrophil azurophil granule. Proteomics 2007, 7, 194-205. [CrossRef] [PubMed]

15. Nebl, T.; Pestonjamasp, K.N.; Leszyk, J.D.; Crowley, J.L.; Oh, S.W.; Luna, E.J. Proteomic analysis of a detergent-resistant membrane skeleton from neutrophil plasma membranes. J. Biol. Chem. 2002, 277, 43399-43409. [CrossRef] [PubMed]

16. Zhang, N.; Shaw, A.R.; Li, N.; Chen, R.; Mak, A.; Hu, X.; Young, N.; Wishart, D.; Li, L. Liquid chromatography electrospray ionization and matrix-assisted laser desorption ionization tandem mass spectrometry for the analysis of lipid raft proteome of monocytes. Anal. Chim. Acta 2008, 627, 82-90. [CrossRef] [PubMed]

17. Dhungana, S.; Merrick, B.A.; Tomer, K.B.; Fessler, M.B. Quantitative proteomics analysis of macrophage rafts reveals compartmentalized activation of the proteasome and of proteasome-mediated ERK activation in response to lipopolysaccharide. Mol. Cell. Proteomics 2009, 8, 201-213. [CrossRef]

18. Bini, L.; Pacini, S.; Liberatori, S.; Valensin, S.; Pellegrini, M.; Raggiaschi, R.; Pallini, V.; Baldari, C.T. Extensive temporally regulated reorganization of the lipid raft proteome following T-cell antigen receptor triggering. Biochem. J. 2003, 369, 301-309. [CrossRef]

19. Lin, S.L.; Chien, C.W.; Han, C.L.; Chen, E.S.; Kao, S.H.; Chen, Y.J.; Liao, F. Temporal proteomics profiling of lipid rafts in CCR6-activated T cells reveals the integration of actin cytoskeleton dynamics. J. Proteome Res. 2010, 9, 283-297. [CrossRef]

20. Gupta, N.; Wollscheid, B.; Watts, J.D.; Scheer, B.; Aebersold, R.; DeFranco, A.L. Quantitative proteomic analysis of B cell lipid rafts reveals that ezrin regulates antigen receptor-mediated lipid raft dynamics. Nat. Immunol. 2006, 7, 625-633. [CrossRef]

21. Man, P.; Novák, P.; Cebecauer, M.; Horváth, O.; Fiserová, A.; Havlícek, V.; Bezouska, K. Mass spectrometric analysis of the glycosphingolipid-enriched microdomains of rat natural killer cells. Proteomics 2005, 5, 113-122. [CrossRef] [PubMed]

22. Foster, L.J.; Chan, Q.W. Lipid raft proteomics: More than just detergent-resistant membranes. Subcell. Biochem. 2007, 43, 35-47. [PubMed]

23. Inder, K.L.; Davis, M.; Hill, M.M. Ripples in the pond-using a systems approach to decipher the cellular functions of membrane microdomains. Mol. Biosyst. 2013, 9, 330-338. [CrossRef] [PubMed]

24. Minogue, S.; Waugh, M.G. Lipid rafts, microdomain heterogeneity and inter-organelle contacts: Impacts on membrane preparation for proteomic studies. Biol. Cell 2012, 104, 618-627. [CrossRef] [PubMed]

25. Mohamed, A.; Shah, A.D.; Chen, D.; Hill, M.M. RaftProt V2: Understanding membrane microdomain function through lipid raft proteomes. Nucleic Acids Res. 2019, 47, D459-D463. [CrossRef] [PubMed]

26. Mohamed, A.; Robinson, H.; Erramouspe, P.J.; Hill, M.M. Advances and challenges in understanding the role of the lipid raft proteome in human health. Expert Rev. Proteomics 2018, 15, 1053-1063. [CrossRef] [PubMed]

27. Zheng, Y.Z.; Berg, K.B.; Foster, L.J. Mitochondria do not contain lipid rafts, and lipid rafts do not contain mitochondrial proteins. J. Lipid Res. 2009, 50, 988-998. [CrossRef] [PubMed] 
28. Anand, P.; Singh, B.; Jaggi, A.S.; Singh, N. Mast cells: An expanding pathophysiological role from allergy to other disorders. Naunyn Schmiedebergs Arch. Pharmacol. 2012, 385, 657-670. [CrossRef]

29. Da Silva, E.Z.; Jamur, M.C.; Oliver, C. Mast cell function: A new vision of an old cell. J. Histochem. Cytochem. 2014, 62, 698-738. [CrossRef]

30. Galli, S.J. The Mast Cell-IgE Paradox: From Homeostasis to Anaphylaxis. Am. J. Pathol. 2016, 186, $212-224$. [CrossRef]

31. Jahn, T.; Leifheit, E.; Gooch, S.; Sindhu, S.; Weinberg, K. Lipid rafts are required for Kit survival and proliferation signals. Blood 2007, 110, 1739-1747. [CrossRef] [PubMed]

32. Holowka, D.; Baird, B. Nanodomains in early and later phases of Fc $\in$ RI signalling. Essays Biochem. 2015, 57, 147-163. [CrossRef] [PubMed]

33. Mazucato, V.M.; Silveira, E.; Souza, A.M.; Nicoletti, L.M.; Jamur, M.C.; Oliver, C. GD1b-derived gangliosides modulate FceRI endocytosis in mast cells. J. Histochem. Cytochem. 2011, 59, 428-440. [CrossRef] [PubMed]

34. Fridriksson, E.K.; Shipkova, P.A.; Sheets, E.D.; Holowka, D.; Baird, B.; McLafferty, F.W. Quantitative analysis of phospholipids in functionally important membrane domains from RBL-2H3 mast cells using tandem high-resolution mass spectrometry. Biochemistry 1999, 38, 8056-8063. [CrossRef] [PubMed]

35. Sadroddiny, E.; Ai, J.; Carroll, K.; Pham, T.K.; Wright, P.; Pathak, A.; Helm, B. Protein profiling of the secretome of FceRI activated RBL-2H3.1 cells. Iran. J. Immunol. 2012, 9, 1-31. [PubMed]

36. Gage, M.C.; Keen, J.N.; Buxton, A.T.; Bedi, M.K.; Findlay, J.B. Proteomic analysis of IgE-mediated secretion by LAD2 mast cells. J. Proteome Res. 2009, 8, 4116-4125. [CrossRef]

37. Han, X.; Smith, N.L.; Sil, D.; Holowka, D.A.; McLafferty, F.W.; Baird, B.A. IgE receptor-mediated alteration of membrane-cytoskeleton interactions revealed by mass spectrometric analysis of detergent-resistant membranes. Biochemistry 2009, 48, 6540-6550. [CrossRef]

38. Dráber, P.; Dráberová, L. Lipid rafts in mast cell signaling. Mol. Immunol. 2002, 38, 1247-1252. [CrossRef]

39. Passante, E.; Frankish, N. The RBL-2H3 cell line: Its provenance and suitability as a model for the mast cell. Inflamm. Res. 2009, 58, 737-745. [CrossRef]

40. Falcone, F.H.; Wan, D.; Barwary, N.; Sagi-Eisenberg, R. RBL cells as models for in vitro studies of mast cells and basophils. Immunol. Rev. 2018, 282, 47-57. [CrossRef]

41. Eccleston, E.; Leonard, B.J.; Lowe, J.S.; Welford, H.J. Basophilic leukaemia in the albino rat and a demonstration of the basopoietin. Nat. New Biol. 1973, 244, 73-76. [CrossRef]

42. Barsumian, E.L.; Isersky, C.; Petrino, M.G.; Siraganian, R.P. IgE-induced histamine release from rat basophilic leukemia cell lines: Isolation of releasing and nonreleasing clones. Eur. J. Immunol. 1981, 11, 317-323. [CrossRef]

43. Rivera, J.; Arudchandran, R.; Gonzalez-Espinosa, C.; Manetz, T.S.; Xirasagar, S. A perspective: Regulation of IgE receptor-mediated mast cell responses by a LAT-organized plasma membrane-localized signaling complex. Int. Arch. Allergy Immunol. 2001, 124, 137-141. [CrossRef]

44. Janes, P.W.; Ley, S.C.; Magee, A.I. Aggregation of lipid rafts accompanies signaling via the T cell antigen receptor. J. Cell Biol. 1999, 147, 447-461. [CrossRef]

45. Guo, N.H.; Her, G.R.; Reinhold, V.N.; Brennan, M.J.; Siraganian, R.P.; Ginsburg, V. Monoclonal antibody AA4, which inhibits binding of IgE to high affinity receptors on rat basophilic leukemia cells, binds to novel alpha-galactosyl derivatives of ganglioside GD1b. J. Biol. Chem. 1989, 264, 13267-13272.

46. Sheets, E.D.; Holowka, D.; Baird, B. Critical role for cholesterol in Lyn-mediated tyrosine phosphorylation of FcepsilonRI and their association with detergent-resistant membranes. J. Cell Biol. 1999, 145, 877-887. [CrossRef]

47. Levental, I.; Grzybek, M.; Simons, K. Greasing their way: Lipid modifications determine protein association with membrane rafts. Biochemistry 2010, 49, 6305-6316. [CrossRef]

48. Lorent, J.H.; Levental, I. Structural determinants of protein partitioning into ordered membrane domains and lipid rafts. Chem. Phys. Lipids 2015, 192, 23-32. [CrossRef]

49. Bhatia, V.N.; Perlman, D.H.; Costello, C.E.; McComb, M.E. Software tool for researching annotations of proteins: Open-source protein annotation software with data visualization. Anal. Chem. 2009, 81, 9819-9823. [CrossRef]

50. Huang, D.W.; Sherman, B.T.; Tan, Q.; Collins, J.R.; Alvord, W.G.; Roayaei, J.; Stephens, R.; Baseler, M.W.; Lane, H.C.; Lempicki, R.A. The DAVID Gene Functional Classification Tool: A novel biological module-centric algorithm to functionally analyze large gene lists. Genome Biol. 2007, 8, R183. [CrossRef] 
51. Simons, K.; Ikonen, E. Functional rafts in cell membranes. Nature 1997, 387, 569-572. [CrossRef]

52. Garner, A.E.; Smith, D.A.; Hooper, N.M. Visualization of detergent solubilization of membranes: Implications for the isolation of rafts. Biophys. J. 2008, 94, 1326-1340. [CrossRef]

53. Brown, D.A.; Rose, J.K. Sorting of GPI-anchored proteins to glycolipid-enriched membrane subdomains during transport to the apical cell surface. Cell 1992, 68, 533-544. [CrossRef]

54. Kim, D.K.; Kim, H.S.; Kim, A.R.; Jang, G.H.; Kim, H.W.; Park, Y.H.; Kim, B.; Park, Y.M.; Beaven, M.A.; Kim, Y.M.; et al. The scaffold protein prohibitin is required for antigen-stimulated signaling in mast cells. Sci. Signal. 2013, 6, ra80. [CrossRef]

55. Poston, C.N.; Duong, E.; Cao, Y.; Bazemore-Walker, C.R. Proteomic analysis of lipid raft-enriched membranes isolated from internal organelles. Biochem. Biophys. Res. Commun. 2011, 415, 355-360. [CrossRef]

56. Rabani, V.; Davani, S.; Gambert-Nicot, S.; Meneveau, N.; Montange, D. Comparative lipidomics and proteomics analysis of platelet lipid rafts using different detergents. Platelets 2016, 27, 634-641. [CrossRef]

57. Foster, L.J.; De Hoog, C.L.; Mann, M. Unbiased quantitative proteomics of lipid rafts reveals high specificity for signaling factors. Proc. Natl. Acad. Sci. USA 2003, 100, 5813-5818. [CrossRef]

58. Zech, T.; Ejsing, C.S.; Gaus, K.; de Wet, B.; Shevchenko, A.; Simons, K.; Harder, T. Accumulation of raft lipids in T-cell plasma membrane domains engaged in TCR signalling. EMBO J. 2009, 28, 466-476. [CrossRef]

59. Souza, S.A.M.; Mazucato, V.M.; de Castro, R.O.; Matioli, F.; Ciancaglini, P.; de Paiva Paulino, T.; Jamur, M.C.; Oliver, C. The alpha-galactosyl derivatives of ganglioside $\mathrm{GD}(1 \mathrm{~b})$ are essential for the organization of lipid rafts in RBL-2H3 mast cells. Exp. Cell Res. 2008, 314, 2515-2528. [CrossRef]

60. Hitomi, T.; Zhang, J.; Nicoletti, L.M.; Grodzki, A.C.; Jamur, M.C.; Oliver, C.; Siraganian, R.P. Phospholipase D1 regulates high-affinity IgE receptor-induced mast cell degranulation. Blood 2004, 104, 4122-4128. [CrossRef]

61. Wilson, B.S.; Pfeiffer, J.R.; Surviladze, Z.; Gaudet, E.A.; Oliver, J.M. High resolution mapping of mast cell membranes reveals primary and secondary domains of Fc(epsilon)RI and LAT. J. Cell Biol. 2001, 154, 645-658. [CrossRef]

62. Holowka, D.; Sheets, E.D.; Baird, B. Interactions between Fc(epsilon)RI and lipid raft components are regulated by the actin cytoskeleton. J. Cell Sci. 2000, 113, 1009-1019.

63. Wang, X.; Ma, D.W.; Kang, J.X.; Kulka, M. N-3 Polyunsaturated fatty acids inhibit Fc $\varepsilon$ receptor I-mediated mast cell activation. J. Nutr. Biochem. 2015, 26, 1580-1588. [CrossRef]

64. Hashimoto, N.; Hamamura, K.; Kotani, N.; Furukawa, K.; Kaneko, K.; Honke, K. Proteomic analysis of ganglioside-associated membrane molecules: Substantial basis for molecular clustering. Proteomics 2012, 12, 3154-3163. [CrossRef]

65. Reeves, V.L.; Thomas, C.M.; Smart, E.J. Lipid rafts, caveolae and GPI-linked proteins. Adv. Exp. Med. Biol. 2012, 729, 3-13. [CrossRef]

66. Kato, N.; Nakanishi, M.; Hirashima, N. Flotillin-1 regulates IgE receptor-mediated signaling in rat basophilic leukemia (RBL-2H3) cells. J. Immunol. 2006, 177, 147-154. [CrossRef]

67. Stuermer, C.A.; Lang, D.M.; Kirsch, F.; Wiechers, M.; Deininger, S.O.; Plattner, H. Glycosylphosphatidyl inositol-anchored proteins and fyn kinase assemble in noncaveolar plasma membrane microdomains defined by reggie-1 and -2. Mol. Biol. Cell 2001, 12, 3031-3045. [CrossRef]

68. Kotani, N.; Nakano, T.; Ida, Y.; Ito, R.; Hashizume, M.; Yamaguchi, A.; Seo, M.; Araki, T.; Hojo, Y.; Honke, K.; et al. Analysis of lipid raft molecules in the living brain slices. Neurochem. Int. 2018, 119, 140-150. [CrossRef]

69. Wang, Z.; Schey, K.L. Proteomic Analysis of Lipid Raft-Like Detergent-Resistant Membranes of Lens Fiber Cells. Invest. Ophthalmol. Vis. Sci. 2015, 56, 8349-8360. [CrossRef]

70. Chowdhury, S.M.; Zhu, X.; Aloor, J.J.; Azzam, K.M.; Gabor, K.A.; Ge, W.; Addo, K.A.; Tomer, K.B.; Parks, J.S.; Fessler, M.B. Proteomic Analysis of ABCA1-Null Macrophages Reveals a Role for Stomatin-Like Protein-2 in Raft Composition and Toll-Like Receptor Signaling. Mol. Cell Proteomics 2015, 14, 1859-1870. [CrossRef]

71. Dwyer, D.F.; Barrett, N.A.; Austen, K.F.; Consortium, I.G.P. Expression profiling of constitutive mast cells reveals a unique identity within the immune system. Nat. Immunol. 2016, 17, 878-887. [CrossRef]

72. Gschwandtner, M.; Paulitschke, V.; Mildner, M.; Brunner, P.M.; Hacker, S.; Eisenwort, G.; Sperr, W.R.; Valent, P.; Gerner, C.; Tschachler, E. Proteome analysis identifies L1CAM/CD171 and DPP4/CD26 as novel markers of human skin mast cells. Allergy 2017, 72, 85-97. [CrossRef]

73. Solstad, T.; Bjørgo, E.; Koehler, C.J.; Strozynski, M.; Torgersen, K.M.; Taskén, K.; Thiede, B. Quantitative proteome analysis of detergent-resistant membranes identifies the differential regulation of protein kinase $\mathrm{C}$ isoforms in apoptotic T cells. Proteomics 2010, 10, 2758-2768. [CrossRef] 
74. Moltu, K.; Bjorgo, E.; Solstad, T.; Berge, T.; Thiede, B.; Taskén, K. A proteomic approach to screening of dynamic changes in detergent-resistant membranes from activated human primary T cells. J. Proteomics Bioinform. 2013, 6, 72-80. [CrossRef]

75. Resh, M.D. Fatty acylation of proteins: The long and the short of it. Prog. Lipid Res. 2016, 63, 120-131. [CrossRef]

76. Lin, Q.; London, E. Transmembrane protein (perfringolysin o) association with ordered membrane domains (rafts) depends upon the raft-associating properties of protein-bound sterol. Biophys. J. 2013, 105, 2733-2742. [CrossRef]

77. De Gassart, A.; Geminard, C.; Fevrier, B.; Raposo, G.; Vidal, M. Lipid raft-associated protein sorting in exosomes. Blood 2003, 102, 4336-4344. [CrossRef]

78. Diaz-Rohrer, B.; Levental, K.R.; Levental, I. Rafting through traffic: Membrane domains in cellular logistics. Biochim. Biophys. Acta 2014, 1838, 3003-3013. [CrossRef]

79. Salaün, C.; James, D.J.; Chamberlain, L.H. Lipid rafts and the regulation of exocytosis. Traffic 2004, 5, $255-264$. [CrossRef]

80. Varshney, P.; Yadav, V.; Saini, N. Lipid rafts in immune signalling: Current progress and future perspective. Immunology 2016, 149, 13-24. [CrossRef]

81. Scorrano, L.; De Matteis, M.A.; Emr, S.; Giordano, F.; Hajnóczky, G.; Kornmann, B.; Lackner, L.L.; Levine, T.P.; Pellegrini, L.; Reinisch, K.; et al. Coming together to define membrane contact sites. Nat. Commun. 2019, 10, 1287. [CrossRef]

82. Kim, B.W.; Lee, J.W.; Choo, H.J.; Lee, C.S.; Jung, S.Y.; Yi, J.S.; Ham, Y.M.; Lee, J.H.; Hong, J.; Kang, M.J.; et al. Mitochondrial oxidative phosphorylation system is recruited to detergent-resistant lipid rafts during myogenesis. Proteomics 2010, 10, 2498-2515. [CrossRef]

83. Dubois, L.; Ronquist, K.K.; Ek, B.; Ronquist, G.; Larsson, A. Proteomic Profiling of Detergent Resistant Membranes (Lipid Rafts) of Prostasomes. Mol. Cell Proteomics 2015, 14, 3015-3022. [CrossRef]

84. Quintana, A.; Schwindling, C.; Wenning, A.S.; Becherer, U.; Rettig, J.; Schwarz, E.C.; Hoth, M. T cell activation requires mitochondrial translocation to the immunological synapse. Proc. Natl. Acad. Sci. USA 2007, 104, 14418-14423. [CrossRef]

85. Cascianelli, G.; Villani, M.; Tosti, M.; Marini, F.; Bartoccini, E.; Magni, M.V.; Albi, E. Lipid microdomains in cell nucleus. Mol. Biol. Cell. 2008, 19, 5289-5295. [CrossRef]

86. Gómez-Llobregat, J.; Buceta, J.; Reigada, R. Interplay of cytoskeletal activity and lipid phase stability in dynamic protein recruitment and clustering. Sci. Rep. 2013, 3, 2608. [CrossRef]

87. Shelby, S.A.; Veatch, S.L.; Holowka, D.A.; Baird, B.A. Functional nanoscale coupling of Lyn kinase with IgE-FcERI is restricted by the actin cytoskeleton in early antigen-stimulated signaling. Mol. Biol. Cell 2016, 27, 3645-3658. [CrossRef]

88. Suzuki, R.; Leach, S.; Liu, W.; Ralston, E.; Scheffel, J.; Zhang, W.; Lowell, C.A.; Rivera, J. Molecular editing of cellular responses by the high-affinity receptor for IgE. Science 2014, 343, 1021-1025. [CrossRef]

89. Surma, M.A.; Klose, C.; Simons, K. Lipid-dependent protein sorting at the trans-Golgi network. Biochim. Biophys. Acta 2012, 1821, 1059-1067. [CrossRef]

90. Iaea, D.B.; Maxfield, F.R. Membrane order in the plasma membrane and endocytic recycling compartment. PLoS ONE 2017, 12, e0188041. [CrossRef]

91. Bissig, C.; Gruenberg, J. Lipid sorting and multivesicular endosome biogenesis. Cold Spring Harb. Perspect. Biol. 2013, 5, a016816. [CrossRef] [PubMed]

92. Wernersson, S.; Pejler, G. Mast cell secretory granules: Armed for battle. Nat. Rev. Immunol. 2014, 14, 478-494. [CrossRef] [PubMed]

93. Blank, U.; Madera-Salcedo, I.K.; Danelli, L.; Claver, J.; Tiwari, N.; Sánchez-Miranda, E.; Vázquez-Victorio, G.; Ramírez-Valadez, K.A.; Macias-Silva, M.; González-Espinosa, C. Vesicular trafficking and signaling for cytokine and chemokine secretion in mast cells. Front. Immunol. 2014, 5, 453. [CrossRef] [PubMed]

94. Kato, N.; Nakanishi, M.; Hirashima, N. Cholesterol depletion inhibits store-operated calcium currents and exocytotic membrane fusion in RBL-2H3 cells. Biochemistry 2003, 42, 11808-11814. [CrossRef] [PubMed]

95. Draber, P.; Halova, I.; Polakovicova, I.; Kawakami, T. Signal transduction and chemotaxis in mast cells. Eur. J. Pharmacol. 2016, 778, 11-23. [CrossRef] [PubMed]

96. Psatha, M.; Koffer, A.; Erent, M.; Moss, S.E.; Bolsover, S. Calmodulin spatial dynamics in RBL-2H3 mast cells. Cell Calcium. 2004, 36, 51-59. [CrossRef] 
97. Bastan, R.; Peirce, M.J.; Peachell, P.T. Regulation of immunoglobulin E-mediated secretion by protein phosphatases in human basophils and mast cells of skin and lung. Eur. J. Pharmacol. 2001, 430, 135-141. [CrossRef]

98. Grochowy, G.; Hermiston, M.L.; Kuhny, M.; Weiss, A.; Huber, M. Requirement for CD45 in fine-tuning mast cell responses mediated by different ligand-receptor systems. Cell Signal. 2009, 21, 1277-1286. [CrossRef]

99. Fowlkes, V.; Wilson, C.G.; Carver, W.; Goldsmith, E.C. Mechanical loading promotes mast cell degranulation via RGD-integrin dependent pathways. J. Biomech. 2013, 46, 788-795. [CrossRef]

100. Kassas, A.; Moura, I.C.; Yamashita, Y.; Scheffel, J.; Guérin-Marchand, C.; Blank, U.; Sims, P.J.; Wiedmer, T.; Monteiro, R.C.; Rivera, J.; et al. Regulation of the tyrosine phosphorylation of Phospholipid Scramblase 1 in mast cells that are stimulated through the high-affinity IgE receptor. PLoS ONE 2014, 9, e109800. [CrossRef]

101. Cruse, G.; Metcalfe, D.D.; Olivera, A. Functional deregulation of KIT: Link to mast cell proliferative diseases and other neoplasms. Immunol. Allergy Clin. North. Am. 2014, 34, 219-237. [CrossRef] [PubMed]

102. Yang, T.; Xie, Z.; Li, H.; Yue, L.; Pang, Z.; MacNeil, A.J.; Tremblay, M.L.; Tang, J.T.; Lin, T.J. Protein tyrosine phosphatase 1B (PTP1B) is dispensable for IgE-mediated cutaneous reaction in vivo. Cell Immunol. 2016, 306-307, 9-16. [CrossRef] [PubMed]

103. Halova, I.; Draber, P. Tetraspanins and Transmembrane Adaptor Proteins As Plasma Membrane Organizers-Mast Cell Case. Front. Cell Dev. Biol. 2016, 4, 43. [CrossRef] [PubMed]

104. Dráberová, L.; Shaik, G.M.; Volná, P.; Heneberg, P.; Tůmová, M.; Lebduska, P.; Korb, J.; Dráber, P. Regulation of $\mathrm{Ca} 2+$ signaling in mast cells by tyrosine-phosphorylated and unphosphorylated non- $\mathrm{T}$ cell activation linker. J. Immunol. 2007, 179, 5169-5180. [CrossRef] [PubMed]

105. Tůmová, M.; Koffer, A.; Simíček, M.; Dráberová, L.; Dráber, P. The transmembrane adaptor protein NTAL signals to mast cell cytoskeleton via the small GTPase Rho. Eur. J. Immunol. 2010, 40, 3235-3245. [CrossRef]

106. Ron, D.; Chen, C.H.; Caldwell, J.; Jamieson, L.; Orr, E.; Mochly-Rosen, D. Cloning of an intracellular receptor for protein kinase C: A homolog of the beta subunit of G proteins. Proc. Natl. Acad. Sci. USA 1994, 91, 839-843. [CrossRef] [PubMed]

107. Ron, D.; Adams, D.R.; Baillie, G.S.; Long, A.; O'Connor, R.; Kiely, P.A. RACK1 to the future-A historical perspective. Cell Commun. Signal. 2013, 11, 53. [CrossRef]

108. Ballek, O.; Valečka, J.; Dobešová, M.; Broučková, A.; Manning, J.; Řehulka, P.; Stulík, J.; Filipp, D. TCR Triggering Induces the Formation of Lck-RACK1-Actinin-1 Multiprotein Network Affecting Lck Redistribution. Front. Immunol. 2016, 7, 449. [CrossRef]

109. Li, S.; Esterberg, R.; Lachance, V.; Ren, D.; Radde-Gallwitz, K.; Chi, F.; Parent, J.L.; Fritz, A.; Chen, P. Rack1 is required for Vangl2 membrane localization and planar cell polarity signaling while attenuating canonical Wnt activity. Proc. Natl. Acad. Sci. USA 2011, 108, 2264-2269. [CrossRef]

110. Sander, L.E.; Frank, S.P.; Bolat, S.; Blank, U.; Galli, T.; Bigalke, H.; Bischoff, S.C.; Lorentz, A. Vesicle associated membrane protein (VAMP)-7 and VAMP-8, but not VAMP-2 or VAMP-3, are required for activation-induced degranulation of mature human mast cells. Eur. J. Immunol. 2008, 38, 855-863. [CrossRef]

111. Puri, N.; Roche, P.A. Mast cells possess distinct secretory granule subsets whose exocytosis is regulated by different SNARE isoforms. Proc. Natl. Acad. Sci. USA 2008, 105, 2580-2585. [CrossRef] [PubMed]

112. Guo, Z.; Turner, C.; Castle, D. Relocation of the t-SNARE SNAP-23 from lamellipodia-like cell surface projections regulates compound exocytosis in mast cells. Cell 1998, 94, 537-548. [CrossRef]

113. Brochetta, C.; Suzuki, R.; Vita, F.; Soranzo, M.R.; Claver, J.; Madjene, L.C.; Attout, T.; Vitte, J.; Varin-Blank, N.; Zabucchi, G.; et al. Munc18-2 and syntaxin 3 control distinct essential steps in mast cell degranulation. J. Immunol. 2014, 192, 41-51. [CrossRef] [PubMed]

114. Wilson, J.D.; Shelby, S.A.; Holowka, D.; Baird, B. Rab11 Regulates the Mast Cell Exocytic Response. Traffic 2016, 17, 1027-1041. [CrossRef] [PubMed]

115. Azouz, N.P.; Matsui, T.; Fukuda, M.; Sagi-Eisenberg, R. Decoding the regulation of mast cell exocytosis by networks of Rab GTPases. J. Immunol. 2012, 189, 2169-2180. [CrossRef] [PubMed]

116. Singh, R.K.; Mizuno, K.; Wasmeier, C.; Wavre-Shapton, S.T.; Recchi, C.; Catz, S.D.; Futter, C.; Tolmachova, T.; Hume, A.N.; Seabra, M.C. Distinct and opposing roles for Rab27a/Mlph/MyoVa and Rab27b/Munc13-4 in mast cell secretion. FEBS J. 2013, 280, 892-903. [CrossRef] [PubMed]

117. Madera-Salcedo, I.K.; Danelli, L.; Tiwari, N.; Dema, B.; Pacreau, E.; Vibhushan, S.; Birnbaum, J.; Agabriel, C.; Liabeuf, V.; Klingebiel, C.; et al. Tomosyn functions as a PKC $\delta$-regulated fusion clamp in mast cell degranulation. Sci. Signal. 2018, 11. [CrossRef] 
118. Nika, K.; Acuto, O. Membrane nanodomains in T-cell antigen receptor signalling. Essays Biochem. 2015, 57, 165-175. [CrossRef]

119. Kovárová, M.; Tolar, P.; Arudchandran, R.; Dráberová, L.; Rivera, J.; Dráber, P. Structure-function analysis of Lyn kinase association with lipid rafts and initiation of early signaling events after Fcepsilon receptor I aggregation. Mol. Cell Biol. 2001, 21, 8318-8328. [CrossRef]

120. Sada, K.; Zhang, J.; Siraganian, R.P. SH2 domain-mediated targeting, but not localization, of Syk in the plasma membrane is critical for FcepsilonRI signaling. Blood 2001, 97, 1352-1359. [CrossRef]

121. Filho, E.G.; da Silva, E.Z.; Zanotto, C.Z.; Oliver, C.; Jamur, M.C. Cross-Linking Mast Cell Specific Gangliosides Stimulates the Release of Newly Formed Lipid Mediators and Newly Synthesized Cytokines. Mediators Inflamm. 2016, 2016, 9160540. [CrossRef] [PubMed]

122. Lacerda Pigosso, L.; Baeza, L.C.; Vieira Tomazett, M.; Batista Rodrigues Faleiro, M.; Brianezi Dignani de Moura, V.M.; Melo Bailão, A.; Borges, C.L.; Alves Parente Rocha, J.; Rocha Fernandes, G.; Gauthier, G.M.; et al. Paracoccidioides brasiliensis presents metabolic reprogramming and secretes a serine proteinase during murine infection. Virulence 2017, 8, 1417-1434. [CrossRef] [PubMed]

123. Li, G.Z.; Vissers, J.P.; Silva, J.C.; Golick, D.; Gorenstein, M.V.; Geromanos, S.J. Database searching and accounting of multiplexed precursor and product ion spectra from the data independent analysis of simple and complex peptide mixtures. Proteomics 2009, 9, 1696-1719. [CrossRef] [PubMed]

124. Bradford, M.M. A rapid and sensitive method for the quantitation of microgram quantities of protein utilizing the principle of protein-dye binding. Anal. Biochem. 1976, 72, 248-254. [CrossRef]

125. Hornbeck, P.V.; Kornhauser, J.M.; Tkachev, S.; Zhang, B.; Skrzypek, E.; Murray, B.; Latham, V.; Sullivan, M. PhosphoSitePlus: A comprehensive resource for investigating the structure and function of experimentally determined post-translational modifications in man and mouse. Nucleic Acids Res. 2012, 40, D261-D270. [CrossRef] [PubMed]

126. Blanc, M.; David, F.P.A.; van der Goot, F.G. SwissPalm 2: Protein S-Palmitoylation Database. Methods Mol. Biol. 2019, 2009, 203-214. [CrossRef]

127. Maurer-Stroh, S.; Koranda, M.; Benetka, W.; Schneider, G.; Sirota, F.L.; Eisenhaber, F. Towards complete sets of farnesylated and geranylgeranylated proteins. PLoS Comput. Biol. 2007, 3, e66. [CrossRef]

128. Maurer-Stroh, S.; Gouda, M.; Novatchkova, M.; Schleiffer, A.; Schneider, G.; Sirota, F.L.; Wildpaner, M.; Hayashi, N.; Eisenhaber, F. MYRbase: Analysis of genome-wide glycine myristoylation enlarges the functional spectrum of eukaryotic myristoylated proteins. Genome Biol. 2004, 5, R21. [CrossRef]

129. Pierleoni, A.; Martelli, P.L.; Casadio, R. PredGPI: A GPI-anchor predictor. BMC Bioinformatics 2008, 9, 392. [CrossRef]

130. Krogh, A.; Larsson, B.; von Heijne, G.; Sonnhammer, E.L. Predicting transmembrane protein topology with a hidden Markov model: Application to complete genomes. J. Mol. Biol. 2001, 305, 567-580. [CrossRef]

131. Tulumello, D.V.; Deber, C.M. Efficiency of detergents at maintaining membrane protein structures in their biologically relevant forms. Biochim. Biophys. Acta 2012, 1818, 1351-1358. [CrossRef] [PubMed]

(C) 2019 by the authors. Licensee MDPI, Basel, Switzerland. This article is an open access article distributed under the terms and conditions of the Creative Commons Attribution (CC BY) license (http://creativecommons.org/licenses/by/4.0/). 

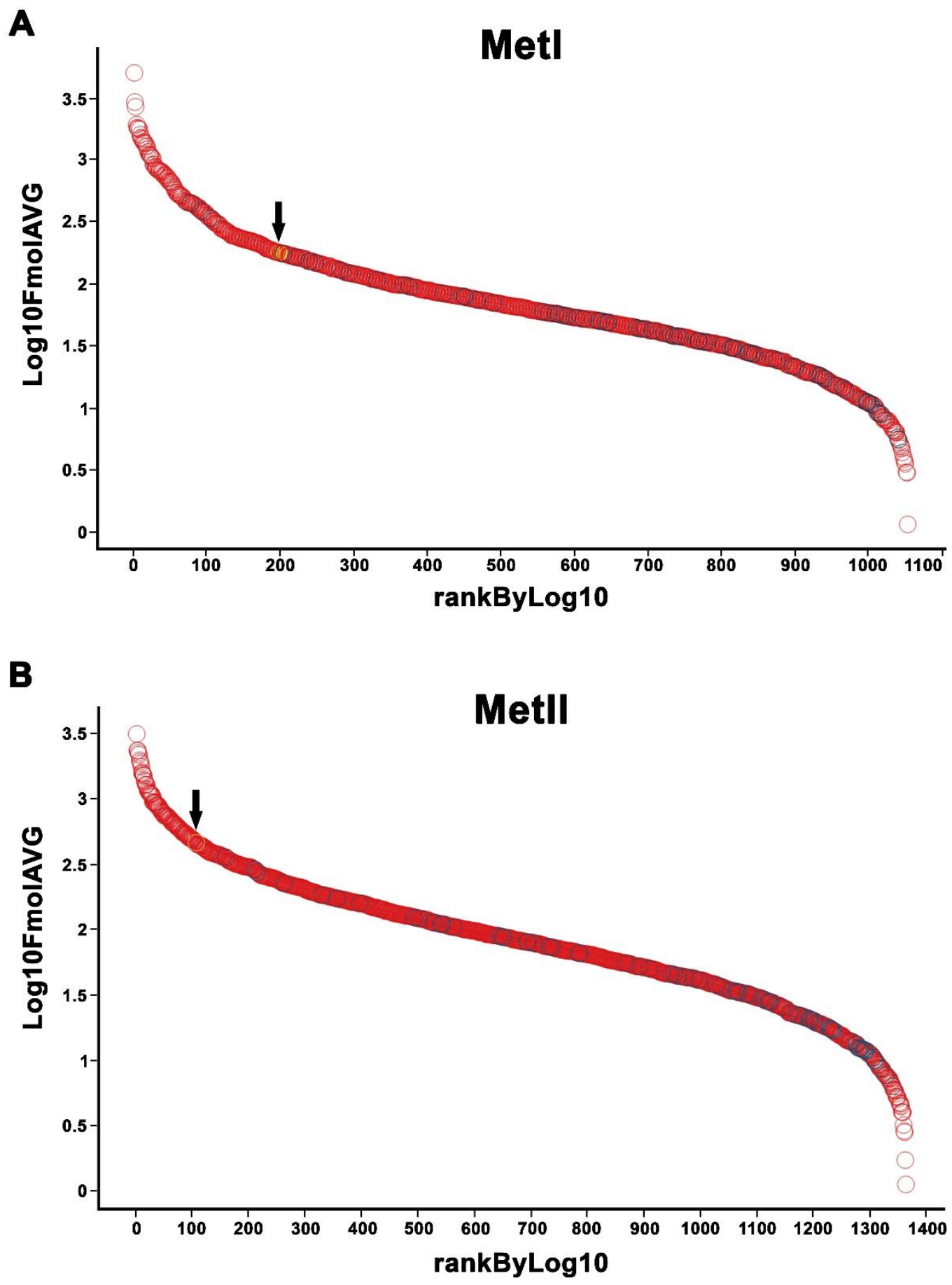

Figure S1. Dynamic range of the proteomic analysis. The graphs show the dynamic range from proteomic experiments for MetI (A) and MetII (B). Regular (red circles), reverse (blue circles) and internal standard (yellow circle; arrow) proteins are indicated. The regular and reverse proteins were identified using regular and reverse genomic databases from Rattus norvegicus. The yeast protein enolase was used as an internal standard. 


\section{Enriched Lipid Rafts}

\begin{tabular}{|llllllllll|}
\hline & $\mid$ & $\mid$ & $\mid$ & $\mid$ & $\mid$ & $\mid$ & $\mid$ & $\mid$ & $\mid$ \\
1 & 2 & 3 & 4 & 5 & 6 & 7 & 8 & 9 & 10 \\
Fraction Number & & &
\end{tabular}

Figure S2. Immuno-blot analysis of the $\beta$-subunit of FceRI from RBL-2H3 MC lipid rafts. Lysates of RBL-2H3 MCs were fractionated by sucrose density gradient ultracentrifugation, and fractions were immunoblotted using a pool of antibodies against the $\beta$-subunit of FceRI. The $\beta$-subunit is found in all fractions. Data is representative of 3 independent experiments. 


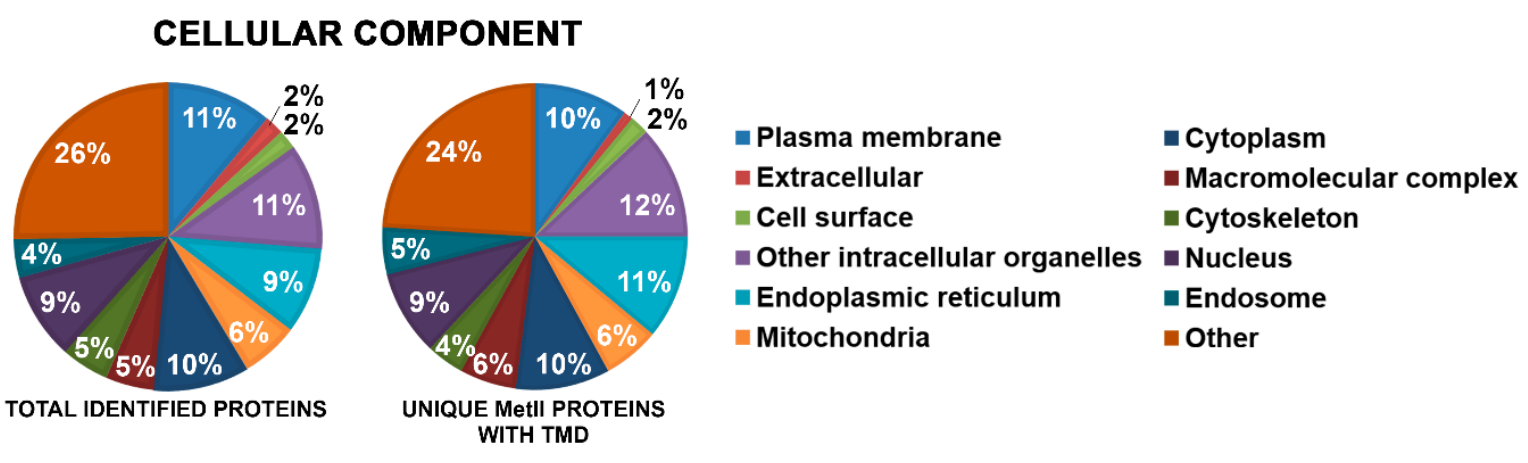

Figure S3: Total identified proteins and unique MetII proteins with transmembrane domains (TMD) have a similar distribution in the Cellular Component GO class. Total identified proteins and unique MetII proteins with TMD were grouped according to the cellular component class of GO. The data is expressed as percentage of proteins associated with each GO term. 


\subsection{CHAPTER III}

Title: RACK1 plays a critical role in F-actin dynamics and calcium mobilization in mast cell secretion

Authors: Edismauro Garcia Freitas Filho, Hwei Ling Ong, William D. Swaim, Indu Suresh Ambudkar, Constance Oliver, and Maria Célia Jamur

Manuscript in preparation. 
1 RACK1 plays a critical role in F-actin dynamics and

2 calcium mobilization in mast cell secretion

3

4

5

6

7

8

9

10

11

12

\author{
Edismauro Garcia Freitas Filho', Hwei Ling Ong ${ }^{2}$, William D. Swaim ${ }^{2}$, Indu \\ Suresh Ambudkar ${ }^{2}$, Constance Oliver $^{1}$, and Maria Célia Jamur ${ }^{1^{*}}$ \\ ${ }^{1}$ Department of Cell and Molecular Biology and Pathogenic Bioagents, Ribeirão Preto Medical School, \\ University of São Paulo, Ribeirão Preto, Av. Bandeirantes 3900, Zip code 14049-900, Ribeirão Preto, SP, \\ Brazil; edismauro@usp.br (E.G.F.F.); lamarinjaca@usp.br (L.A.M.J.); coliver@fmrp.usp.br (C.O.) \\ 2 Secretory Physiology Section, National Institute of Dental and Craniofacial Research, National Institutes of \\ Health, Bethesda, MD, Zip code 20892, USA; ongh@nidcr.nih.gov (H.L.O); bswaim@dir.nidcr.nih.gov \\ (W.D.S); iambudkar@dir.nidcr.nih.gov (I.S.A) \\ * Correspondence: mjamur@fmrp.usp.br (M.C.J); Tel.: +55-163315-3142
}

Running tittle: RACK1 is essential in mast cell actin dynamics and calcium signaling

Keywords: RACK1, degranulation, actin cytoskeleton, Store-operated calcium entry, mast cells

\title{
ABSTRACT
}

RACK1 acts as a signaling hub in immune cell responses. Mast cell (MC) activation via antigen results in mediator release and is preceded by cytoskeleton reorganization and calcium mobilization. The relevance of RACK1 to these processes is unknown. RACK1 was first identified in MCs by our laboratory through proteomic analysis of lipid rafts. RACK1 was distributed throughout the cytoplasm in MCs and was localized adjacent to the plasma membrane in antigen stimulated RBL-2H3 MCs. After RACK1 knockdown (KD) RBL-2H3 cells were rounded and the cortical F-actin was fragmented. In antigen-stimulated RACK1 KD MCs, cortical F-actin was reduced. The F-actin disarrangement was further characterized by TIRFM analysis of LifeAct-RFP transfected MCs. RACK1 depletion increased degranulation in MCs. $\mathrm{CD}^{+}{ }^{+}$-secretory granules were localized in F-actin-free cortical regions in non-stimulated RACK1-KD MCs. RACK1 KD cells showed a decrease in the secretion of newly synthesized mediators. Additionally, RACK1 depletion increased antigenstimulated $\mathrm{Ca}^{2+}$-mobilization, but impaired antigen-stimulated $\mathrm{Ca}^{2+}$ ER-store depletion and thapsigargin-induced $\mathrm{Ca}^{2+}$-entry. Following $\mathrm{MC}$ antigen-activation there was an increase in interaction of RACK1 with $\beta$-actin and Orai1 $\mathrm{Ca}^{2+}$-channel. Our results show that RACK1 is a critical regulator of mediator secretion, actin dynamics and calcium signaling in MCs. 


\section{INTRODUCTION}

Allergic reactions and associated inflammatory processes are triggered by multivalent antigens crosslinking antigen-specific IgE previously bound to the high affinity IgE receptor (FceRI) on the surface of mast cells (MCs) and basophils (da Silva et al., 2014; Galli, 2016; Karasuyama et al., 2018). Antigen binding activates MCs to release preformed mediators, such as histamine, proteases, proteoglycans and $\beta$-hexosaminidase stored in cytoplasmic secretory granules (SGs) in a process commonly referred to as degranulation. This is followed by the release of newly formed lipid mediators such as prostaglandin D2 (PGD2) and leukotriene C4 (LTC4). Eight to 12 hours later, newly synthesized mediators (cytokines/chemokines) are released (Blank et al., 2014; Mukai et al., 2018; Wernersson and Pejler, 2014).

Cross-linking of FceRI on MCs results in an initial signaling cascade markedly by activation of the Src-family tyrosine kinases, such as Lyn and Fyn, and the tyrosine kinase Syk. Activated Lyn and Syk phosphorylate a number of targets crucial for further propagation of the signal. PLC $\gamma$-mediated hydrolysis of membrane bound $\mathrm{PI}(4,5) \mathrm{P}_{2}$ generates the second messengers DAG (1,2-diacylglycerol) and $\mathrm{IP}_{3}$ (inositol-1,4,5-triphosphate) that binds to $\mathrm{IP}_{3}$ receptors on the endoplasmic reticulum (ER) (Siraganian et al., 2010). This results in $\mathrm{Ca}^{2+}$ release from ER stores. Subsequently, depletion of $\mathrm{Ca}^{2+}$ from ER lumen induces $\mathrm{Ca}^{2+}$ influx across the plasma membrane through stored-operated $\mathrm{Ca}^{2+}$ channels, such as Orai1/CRACM1 and TRPC1, a process referred as store-operated calcium entry (SOCE) (Ambudkar et al., 2017; Baba et al., 2008; Vig et al., 2008). The SOCE-dependent calcium mobilization acts as a second messenger for cytoskeleton reorganization and for the fusion of SGs to the plasma membrane, resulting in MC degranulation and mediator release (Cohen et al., 2012; Wollman and Meyer, 2012).

Membrane-cytoskeleton rearrangement is an integral part of mediator secretion in activated MCs. Changes in the arrangement of microtubules and actin microfilaments are required for degranulation (Dráber et al., 2012; Wollman and Meyer, 2012). In absence of stimulation the cortical F-actin provides a barrier preventing access of the SGs to the plasma membrane. In contrast, stimulus-induced disassembly of the cortical F-actin network is necessary for MC degranulation (Deng et al., 2009; Nishida et al., 2005; Wilson et al., 2016).

While significant progress has been made in our understanding of the regulatory pathways during MC activation, the molecular components involved in regulated secretion are still not fully elucidated (Blank et al., 2014; Wernersson and Pejler, 2014). RACK1 (receptor 
for activated $\mathrm{C}$ kinase 1 ) is a member of the tryptophan-aspartate repeat (WD-repeat) family of proteins and has a seven-bladed $\beta$-propeller structure, which permits the binding of multiple partners. A feature that enables RACK1 to act as a hub that nucleates key signaling complexes (Adams et al., 2011; Ron et al., 1994). The ability of RACK1 to integrate various signaling pathways is important in immune cell response, since this process requires precise regulation of signaling between various receptors, changes in intracellular calcium concentration $\left(\left[\mathrm{Ca}^{2+}\right]_{\mathrm{i}}\right)$, and cytoskeleton rearrangement (Ballek et al., 2016; Ron et al., 2013). Modifications in the expression level of RACK1 have been associated with abnormal release of inflammatory mediators by immune cells such as leukocytes, macrophages and dendritic cells (Corsini et al., 2015; Corsini et al., 2014; Yao et al., 2014). Additionally, the gene gnb2ll, which encodes RACK1, appears to be involved in asthma (Hwang et al., 2008). In asthmatic patients, aberrant $\mathrm{Ca}^{2+}$ influx compromises the function of $\mathrm{T}$ regulatory cells that can be correlated with a high level of RACK1 (Negoro et al., 2014) and RACK1 expression is also increased in lungs of ovalbumin (OVA)-induced asthma in Balb/c mice (Pu et al., 2018). It is known that acute asthma is triggered by MCs activation (Bradding and Arthur, 2016) and, although the presence of RACK1 was recently reported in a proteomic analysis of lipid rafts isolated from RBL-2H3 MCs (Freitas-Filho et al., 2019), the functional role of RACK1 in MCs has not been previously investigated. In the present study, the involvement of RACK1 in MC mediator release is shown. Previously undescribed roles of RACK1 in actin cytoskeleton dynamics as well as in calcium signaling are reported.

\section{RESULTS}

\section{RACK1 is expressed in mast cells}

A proteomic study of lipid rafts isolated from RBL-2H3 cells demonstrated, for the first time, the presence of RACK1 in MCs (Freitas-Filho et al., 2019). It was then of interest to examine the presence and distribution of RACK1 in mouse resident lung MCs, mouse bone marrow-derived mast cells (BMMCs), the human MC line ROSA (KIT D816V), and the rat MC line RBL-2H3. In lung, RACK1 co-localized with mouse MC tryptase 6, a MC specific marker (Pejler et al., 2007) (Fig. 1A). In BMMCs (Fig. 1B), ROSA MCs (Fig. 1C), as well as in RBL-2H3 MCs (Fig. 1D), RACK1 displayed a punctate staining pattern that was dispersed throughout the cytoplasm. These results confirm the previous proteomic findings and demonstrate that RACK1 is present in MCs both in vivo and in vitro. 
A
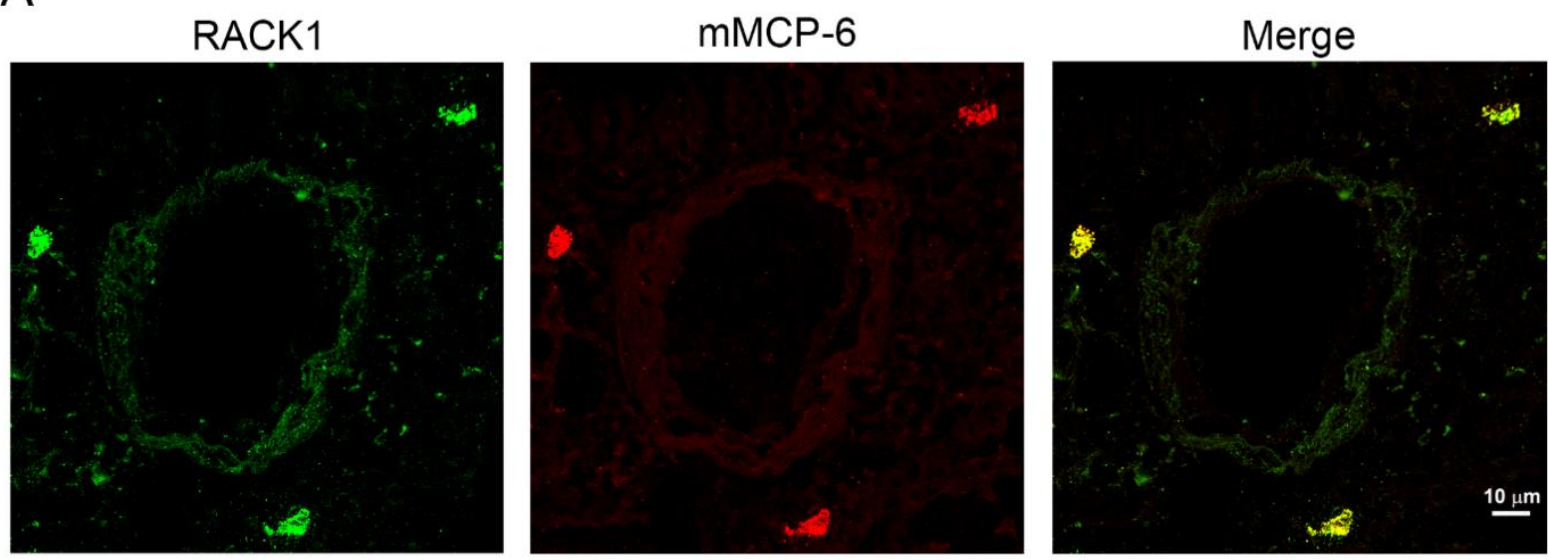

Lung

B

C

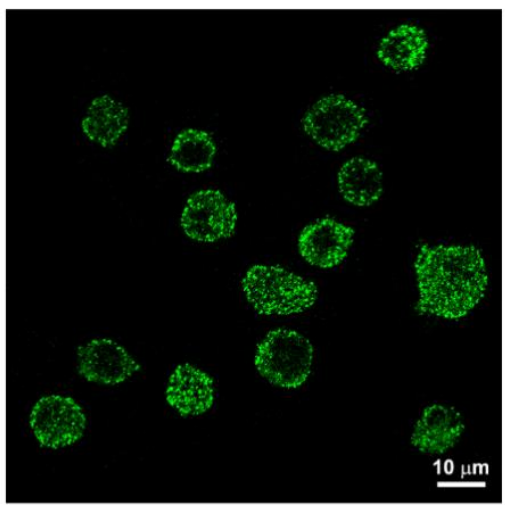

BMMCs

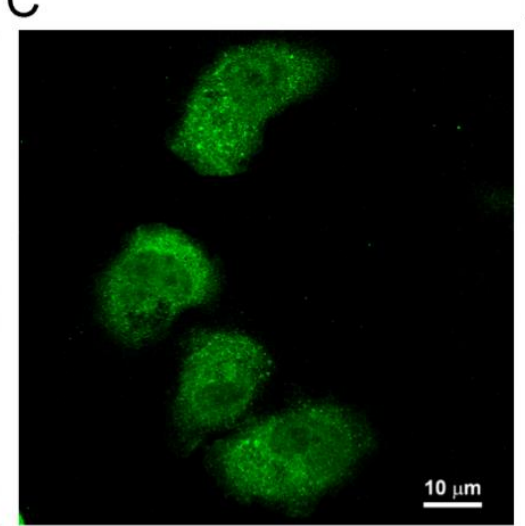

ROSA MCs

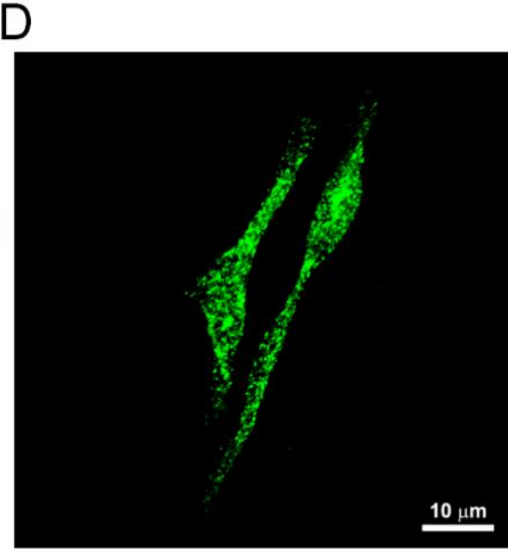

RBL-2H3 MCs

Figure 1. RACK1 is present in mast cells both in vivo and in vitro. By scanning confocal microscopy, RACK1 is present in $(\mathbf{A})$ mouse resident lung $\mathrm{MCs},(\mathbf{B})$ bone marrow-derived mast cells (BMMCs), (C) human MC line ROSA (KIT D816V), and (D) rat MC line RBL-2H3. The lung was immunolabeled with antibody against RACK1 followed by secondary antibody anti-goat IgG conjugated with Alexa 488 (green) and antibody against mouse mast cell tryptase 6 (MCP-6) followed by secondary antibody anti-rabbit IgG conjugated with Alexa 594 (red). BMMCs, ROSA MCs, and RBL-2H3 MCs were immunolabeled with antibody against RACK1 followed by secondary antibody anti-rabbit IgG conjugated with Alexa 488. Representative of maximum intensity Z projection images from three independent experiments are shown.

\section{RACK1 distribution changes following mast cell activation via FceRI}

The functional role of RACK1 was further investigated using primarily RBL-2H3 MCs, a widely used model to study MC secretion (Falcone et al., 2018). The cells were stimulated via FceRI, the best characterized pathway for MC activation, and the distribution of RACK1 in non-stimulated and stimulated cells was then analyzed. In non-stimulated cells, RACK1 was localized adjacent to the plasma membrane and distributed throughout the cytoplasm in a punctate manner. However, after antigen stimulation for $1 \mathrm{~min}$ and $5 \mathrm{~min}$, the intensity of RACK1 immunostaining increased adjacent to the plasma membrane and in perinuclear regions (Fig. 2), indicating that the distribution of RACK1 is related to the physiological state of the MCs. 

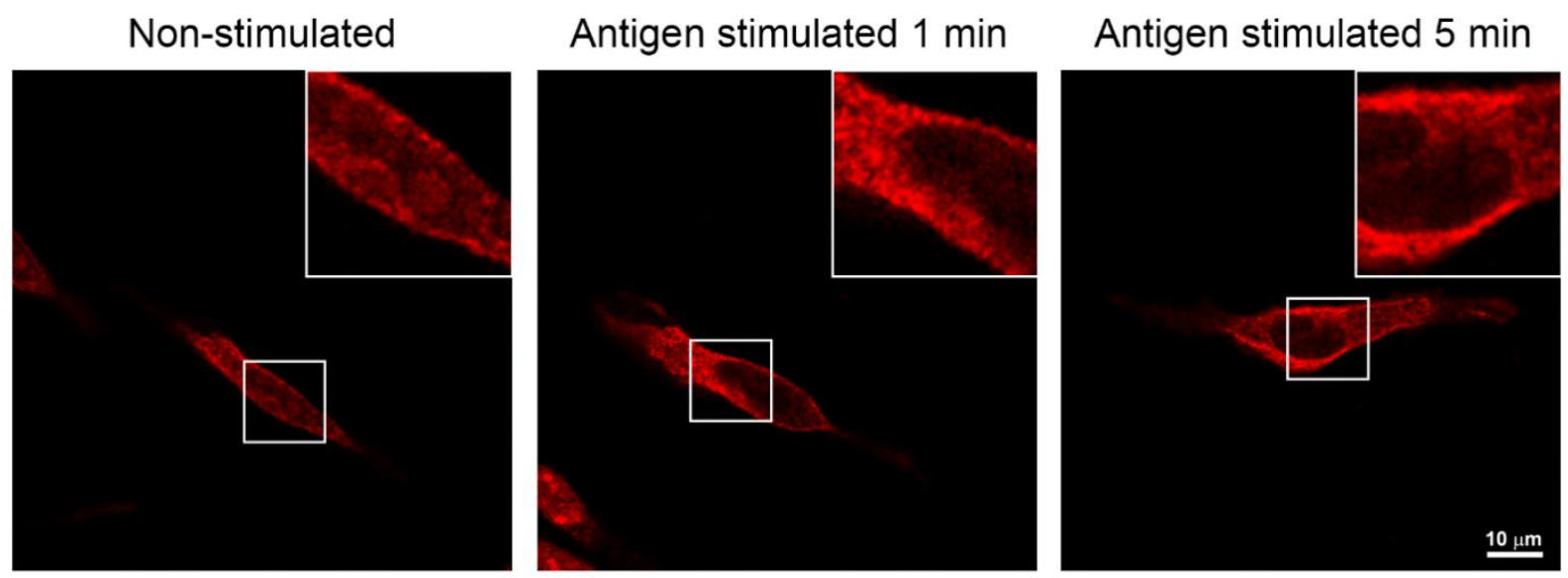

Figure 2. RACK1 increases adjacent to the plasma membrane and in perinuclear regions after mast cell activation. RBL-2H3 MCs were sensitized with IgE anti-TNP and stimulated via FceRI or not with $50 \mathrm{ng} / \mathrm{mL}$ $\mathrm{DNP}_{54}-\mathrm{HSA}$ for $1 \mathrm{~min}$ and $5 \mathrm{~min}$. Samples were immunolabeled with antibody against RACK1 followed by secondary antibody anti-rabbit IgG conjugated with Alexa 594. A representative single optical slice $(0.17 \mu \mathrm{m})$ through the nucleus obtained by scanning confocal microscopy from three independent experiments is shown.

\section{shRNA mediated depletion of RACK1 interferes with mast cell morphology}

In order to further investigate the involvement of RACK1 in MC function, RBL-2H3

MCs were transduced with lentiviral particles encoding shRNAs against RACK1 to generate

RACK1 knockdown (KD) MCs (clones ShRACK1 cl.12 and ShRACK1 cl.29). Qualitative RT-PCR showed an approximately 68\% decrease in RACK1 mRNA expression compared to cells expressing a non-targeting shRNA (ShCtrl) (Fig. 3A). Furthermore, western blot analysis demonstrated that RACK1 knockdown leads to an approximately reduction of $60 \%$ in RACK1 protein levels (Fig. 3B-C). Protein expression of RACK1 was lower in ShRACK1 cl.29 cells than in ShRACK1 cl.12 cells, but there was no statistic significant difference between them. Therefore, the ShRACK1 cl.29 MCs were adopted for all further microscopic studies. Additionally, these results also demonstrated that after transfection with control shRNA (ShCtrl), mRNA expression and protein levels of RACK1 were similar to untransduced cells (UT), confirming that transduction with non-targeting shRNA did not affect RACK1 expression (Fig. 3A-C). 
A

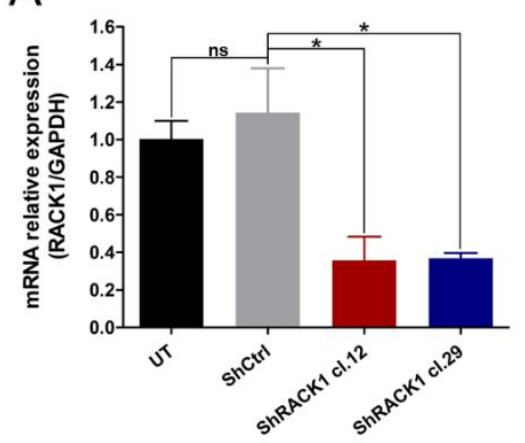

B

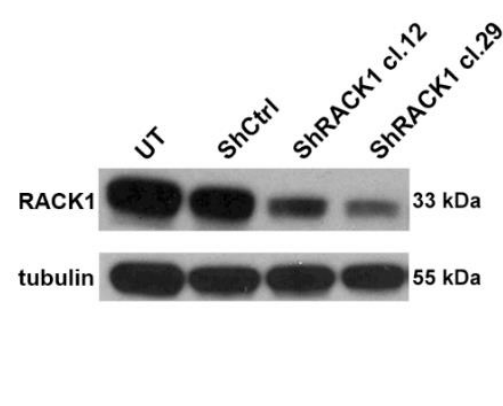

C

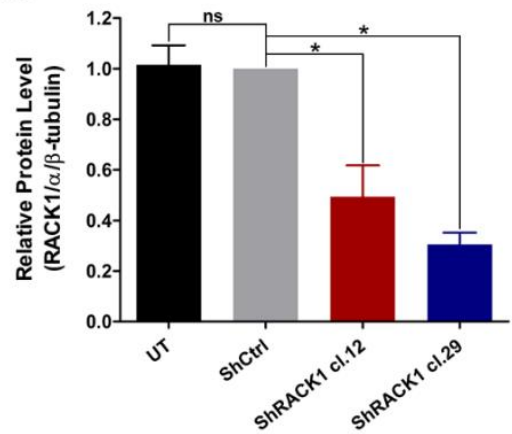

Figure 3. Transduction with RACK1shRNA of RBL2H3 mast cells partially depletes RACK1. To knock down RACK1, RBL-2H3 MCs were transduced with lentiviral particles expressing non-targeting control shRNA (ShCtrl) or with particles expressing shRNAs against RACK1 (ShRACK1 cl.12 and ShRACK1 cl.29). (A) RACK1 mRNA expression was determined by quantitative RT-PCR using GAPDH mRNA expression as an internal control. (B) Total cell lysates were immunoblotted with antibodies against RACK1 and $\alpha / \beta$-tubulin and representative Western blot images are shown. (C) Mean optical density of the Western blots was determined and relative protein levels of RACK $1 / \alpha / \beta$-tubulin were calculated. The protein ratio was set at 1 for ShCtrl. Data are expressed as the mean \pm SD of a minimum of 4 independent experiments. ${ }^{*} p<0.01$ vs. ShCtrl. ns: not significant. UT: untransduced cells.

When MCs are stimulated via FceRI, they undergo rapid morphological changes (Dráber et al., 2012). Since RACK1 has been correlated with maintenance of morphology in diverse cell types (Kershner and Welshhans, 2017; Klímová et al., 2016; O'Donovan et al., 2007), it was important to examine the role of RACK1 in regulating cellular morphology. By scanning electron microscopy, control cells (UT and ShCtrl) had the typical fusiform morphology of RBL-2H3 MCs, and their surface was covered with small, short microvilli (Fig. 4A). In contrast, the majority of RACK1 KD MCs (ShRACK1 cl.29) displayed a round or oval shape and their surface was altered with a few ruffles (Fig. 4A). The roundness index (RI) (Schober et al., 2009) and cell area were determined after staining the actin cytoskeleton with phalloidin-Alexa 488 (Supplemental Fig. 1). RACK1 KD cells demonstrated a significant increase in RI measurement when compared with ShCtrl cells (Fig. 4B). Moreover, there were no differences in the cell area of the analyzed cells (Fig. 4C). 


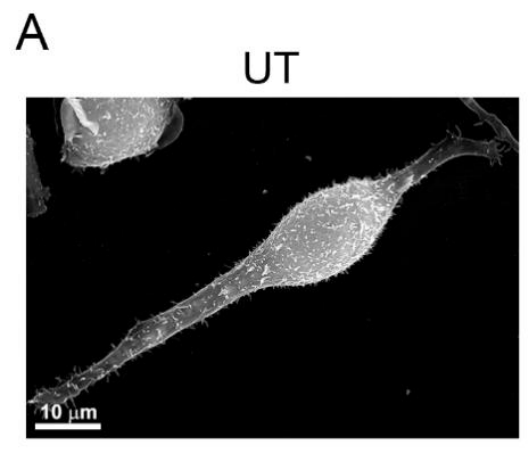

B

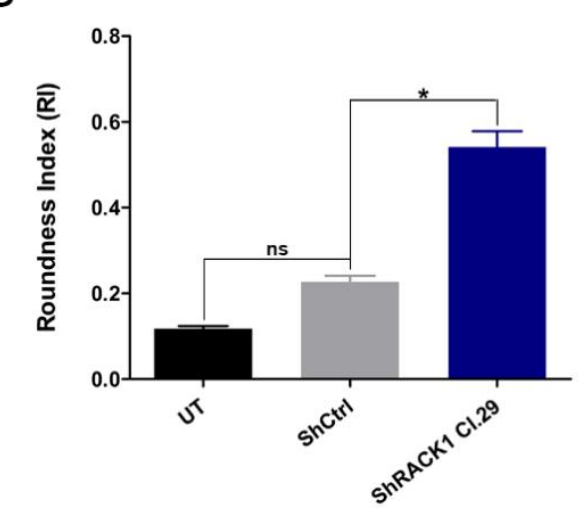

ShCtrl

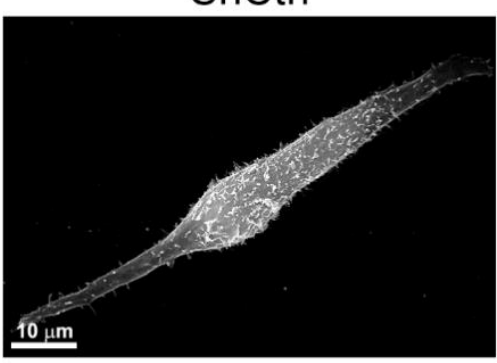

ShRACK1 cl.29

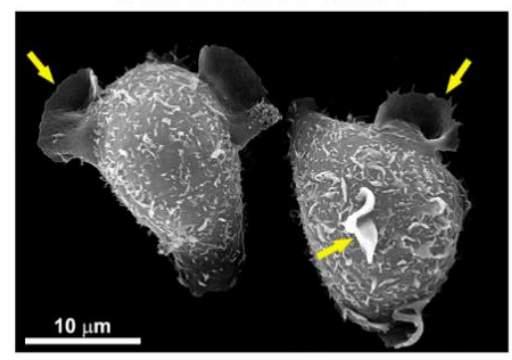

C

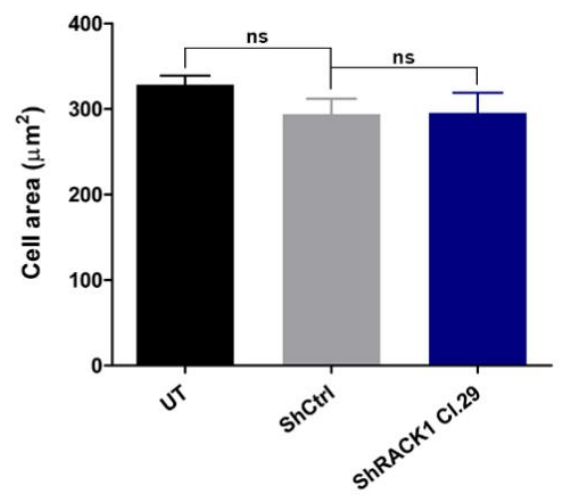

Figure 4. RACK1 is involved in the maintenance of mast cell morphology. (A) Scanning electron microscopy (SEM) of untransduced RBL-2H3 MCs (UT), control shRNA transduced MCs (ShCtrl) and RACK1 KD MCs (ShRACK1 cl.29). Representative images from three independent experiments are shown. Arrows: surface ruffles. RBL-2H3 MCs transduced or not with shRNA were stained with phalloidin conjugated with Alexa 488 to visualize the cell morphology and the $(\mathbf{B})$ roundness index $(\mathrm{RI})$ and $(\mathbf{C})$ cell area were quantified. A minimum of 45 cells was analyzed for each condition. Data are expressed as the mean \pm SEM of three independent experiments. $* \mathrm{p}<0.01$ vs. ShCtrl. ns: not significant.

\section{RACK1 is necessary for actin cytoskeleton organization}

Because the shape of the RACK1 KD MCs was altered, it was of interest to investigate the actin cytoskeleton distribution in these cells (Fig. 5). In non-stimulated UT cells and ShCtrl cells, the actin filaments (F-actin) were continuous, especially those in the cortical regions. In contrast, in non-stimulated RACK1 KD MCs (ShRACK1 cl.29) the cortical Factin was fragmented with spaces in the subcortical areas. A similar phenotype was observed when ShCtrl cells were pretreated with latrunculin B (LatB) at low concentration (ShCtrl + LatB), which inhibits actin polymerization (Spector et al., 1983), indicating that RACK1 is involved in maintaining the integrity of the cortical F-actin (Fig. 5A). Following 5 min of stimulation, in control cells (UT and ShCtrl), F-actin was primarily localized to continuous filaments adjacent to the plasma membrane and associated with surface ruffles and microvilli. In RACK1 KD cells stimulated for the same time, cortical F-actin was interrupted by numerous spaces and there was a significant decrease in the fluoresce intensity of F-actin. Additionally, when ShCtrl cells were pretreated with LatB and then stimulated, the F-actin 
A
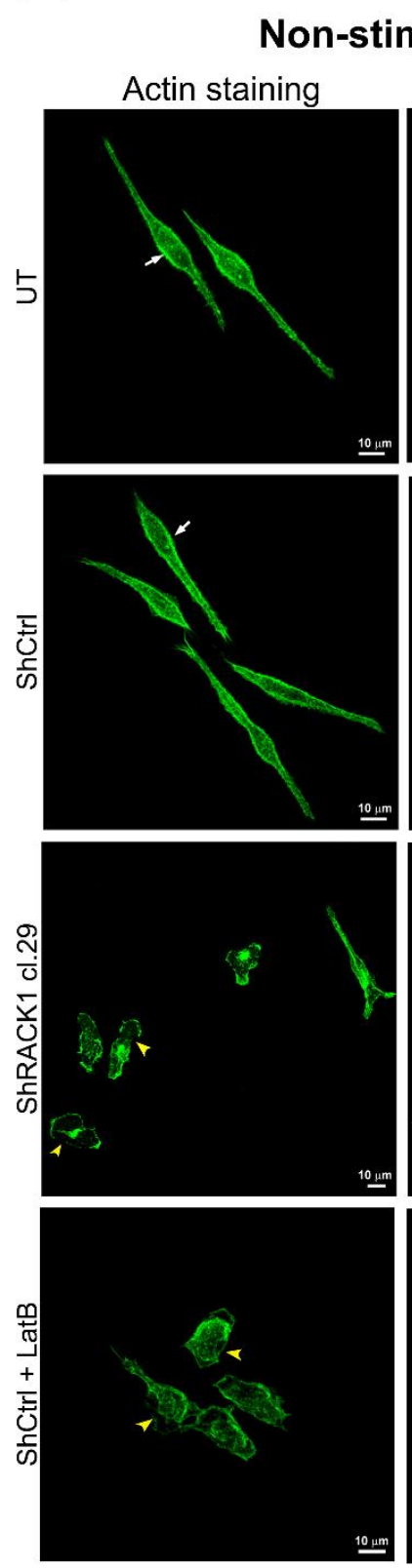

B

\section{Antigen stimulated 5 min}

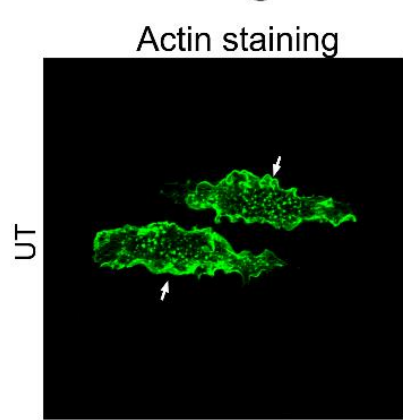

Fire look-up-table
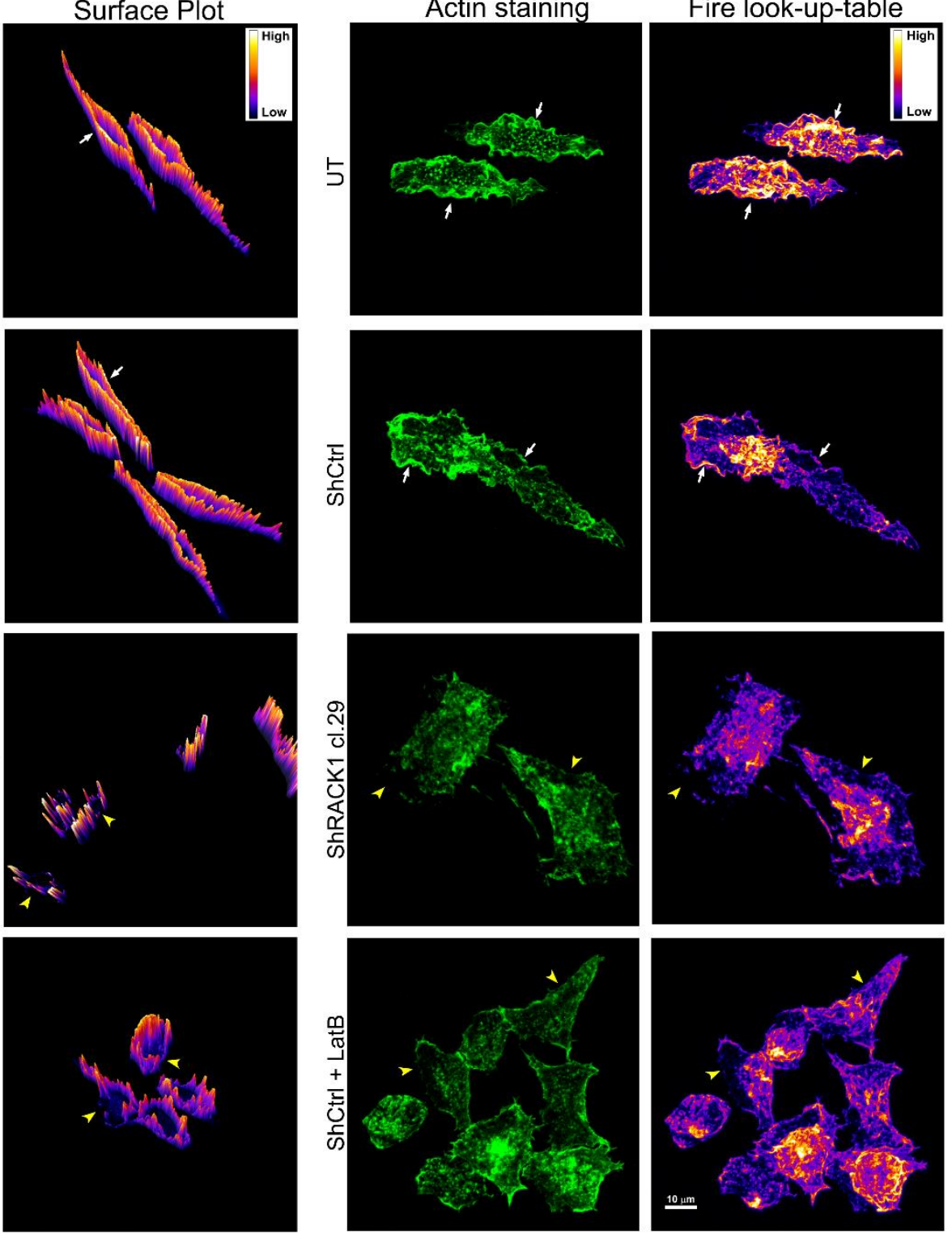

Figure 5. Rack1 knockdown affects the actin cytoskeleton organization in resting and antigen stimulated mast cells. Untransduced RBL-2H3 MCs (UT), control shRNA transduced cells (ShCtrl), RACK1 KD MCs (ShRACK1 cl.29), and ShCtrl cells pretreated with $0.5 \mu \mathrm{M}$ latrunculin B (ShCtrl + LatB) were stained for F-actin with phalloidin conjugated with Alexa 488. Representative confocal microscopy images of (A) non-stimulated cells and (B) IgE anti-TNP sensitized and stimulated via FceRI with $50 \mathrm{ng} / \mathrm{mL} \mathrm{DNP}_{54}$-HSA for $5 \mathrm{~min}$. White arrows: continuous cortical F-actin. Yellow arrowheads: F-actin free cortical regions. Images are representative of three independent experiments.

Since the actin cytoskeleton was disorganized in RACK1 KD MCs, it was of interest to investigate the impact of RACK1 knockdown on F-actin dynamics during MC activation. 
202

203

204

205

206

207

208

209

210

211

212

213

214

215

LifeAct-RFP and the actin rearrangement following antigen stimulation was examined in living cells by total internal reflection fluorescence microscopy (TIRFM). A rapid decrease in cortical F-actin levels was observed soon (50 s) after antigen stimulation in ShCtrl cells.

Subsequently, F-actin returned as fluorescent puncta (400 s), and at later times (600 s) appeared as a highly organized network of filaments in cell cortex (Fig. 6) (Supplemental video 1). In contrast, in non-stimulated RACK1 KD MCs, cortical F-actin was already disorganized (Fig. 6; $0 \mathrm{~s}$ ). With time after stimulation, cortical F-actin intensity appeared to rise, but in a completely disorganized manner and persist even later (600 s), forming large aggregates throughout cell cortex, instead of the organized filaments seen in the ShCtrl cells (Fig. 6) (Supplemental video 2). Moreover, RACK1 knockdown had no effect on the expression of $\beta$-actin mRNA and protein levels (Supplemental Fig. 2). These results indicate that RACK1 has an essential role in actin cytoskeleton organization and stimulus-induced Factin dynamics in MCs.

\section{ShCtrl}

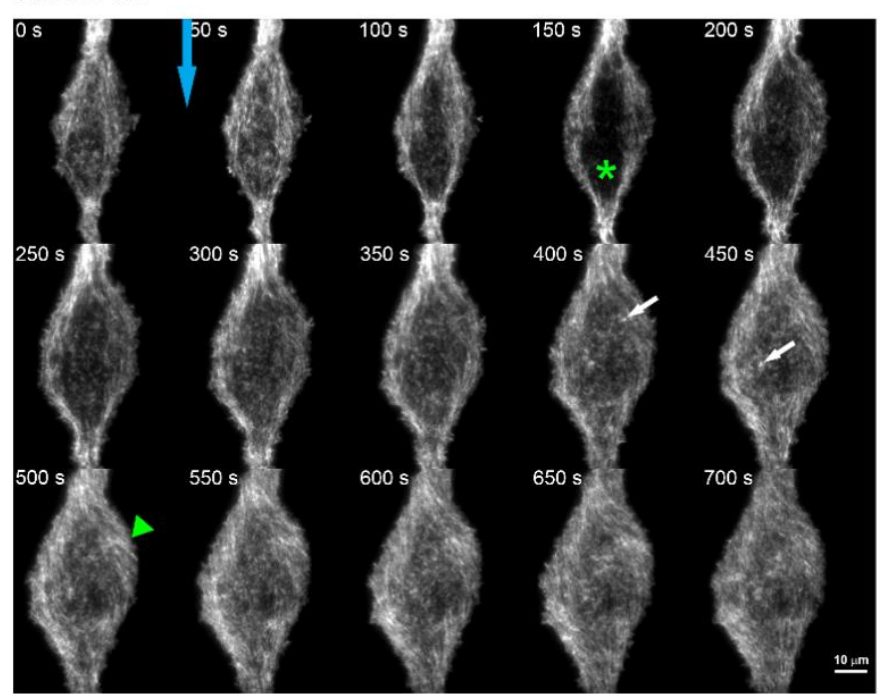

ShRACK1 cl.29

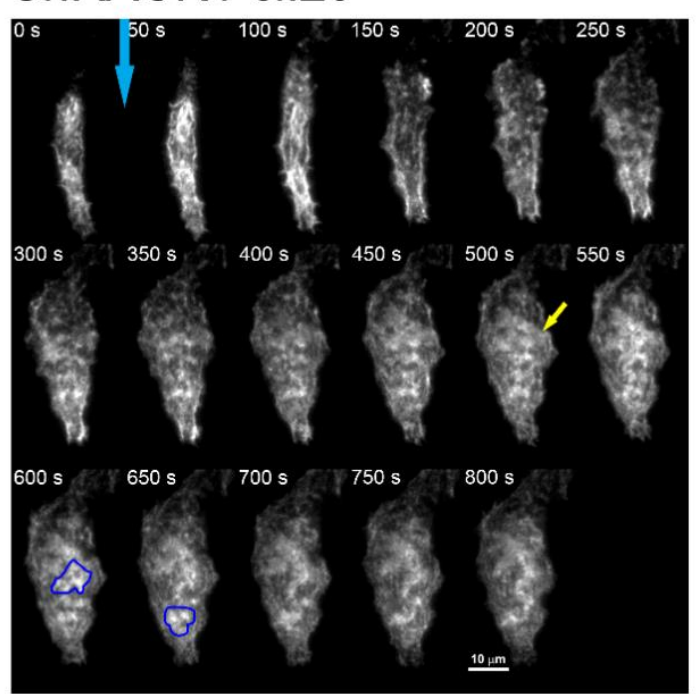

Figure 6. shRNA mediated depletion of Rack1 affects F-actin dynamics following antigen stimulation. shRNA transduced RBL-2H3 MCs were transiently transfected with LifeAct-RFP. After 24 h, cells were sensitized with IgE anti-TNP and stimulated via FceRI with $50 \mathrm{ng} / \mathrm{mL}$ DNP $_{54}$-HSA (blue arrow) and observed by TIRFM. green *: decrease in cortical F-actin intensity. White arrow: punctate F-actin. Arrowhead: organized network of Factin. Yellow arrow: disorganized F-actin. Blue demarcated areas: F-actin aggregates. Images are representative of two independent experiments with a minimum of 6 cells for each condition.

\section{$\beta$-actin binds to RACK1 in mast cells}

To further investigate the relationship between the actin cytoskeleton and RACK1, the possible interaction of RACK1 with $\beta$-actin was examined. RACK1 was immunopreciptated from RBL-2H3 MC lysates with or without antigen stimulation. No difference was seen in the expression of RACK1 following MC activation (Fig. 7A-B). Furthermore, $\beta$-actin, one of the 
major isoforms of actin in non-muscle cells (Perrin and Ervasti, 2010), co-precipitated with RACK1 in non-stimulated and antigen stimulated cells. The amount of $\beta$-actin coprecipitating with RACK1 increased on average 3.5-fold 1 or 5 min after cell activation (Fig. 7C-D). The ability of $\beta$-actin to co-precipitate with endogenous RACK1 was not altered due to LatB treatment, moreover, the $\beta$-actin co-precipitating with RACK1 was increased in LatB pretreated cells (Fig. 7E-F).

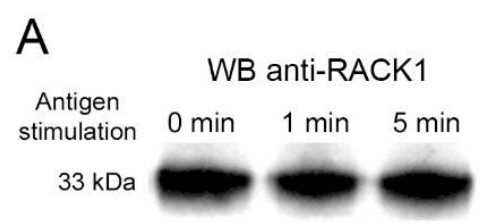

IP anti-RACK1

B

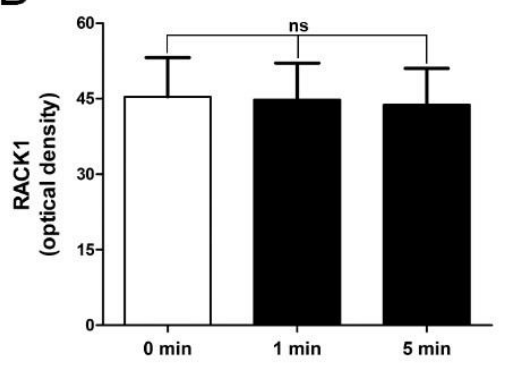

C

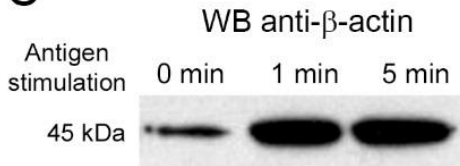

IP anti-RACK1

$\mathrm{D}$

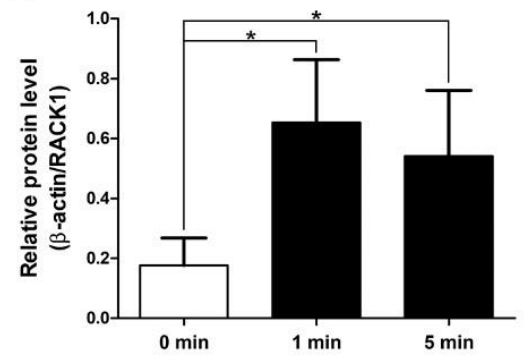

$E$

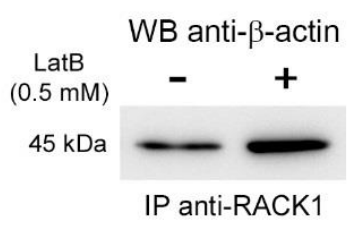

$\mathrm{F}$

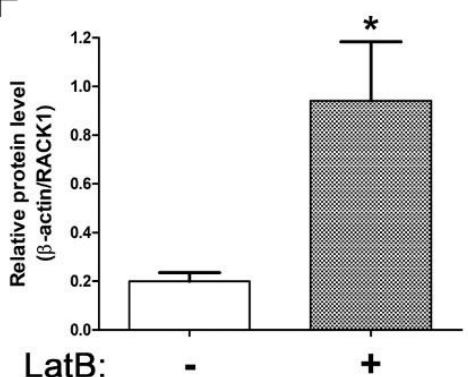

Figure 7. $\boldsymbol{\beta}$-actin binds to RACK1 in RBL-2H3 mast cells. (A) RBL-2H3 MCs were sensitized with IgE antiTNP and stimulated via FceRI with $50 \mathrm{ng} / \mathrm{mL} \mathrm{DNP}_{54}$-HSA or not. RACK1 was immunoprecipitated with rabbit IgG anti-RACK1 from lysates of non-stimulated $(0 \mathrm{~min})$ and cells stimulated with antigen for $1 \mathrm{~min}$ and $5 \mathrm{~min}$. RACK1 immunoprecipitates were blotted with anti-RACK1. (B) Quantification of RACK1 from immunoprecipitated samples blotted with anti-RACK1. (C) RACK1 immunoprecipitates were blotted with anti$\beta$-actin. (D) The relative amount of $\beta$-actin co-immunoprecipitated was normalized against the amount of RACK1 precipitated (E) non-stimulated RBL-2H3 MCs were pretreated (+) or not (-) with $0.5 \mu \mathrm{M}$ latrunculin B (LatB) for 15 min and RACK1 was immunoprecipitated. RACK1 immunoprecipitates were blotted with anti- $\beta$-actin. (F) The relative amount of $\beta$-actin co-immunoprecipitated was normalized against the amount of RACK1 precipitated. Representative Western blot images are shown. Data are expressed as the mean \pm SD of three independent experiments. ${ }^{*} \mathrm{p}<0.01$ vs. 0 min or (-). ns: not significant.

\section{RACK1 plays a key role in regulated secretion of preformed mediators}

The cortical F-actin modulates the secretion of preformed mediators stored in SGs of MCs (Wollman and Meyer, 2012). Therefore, the release of the preformed mediator $\beta$ hexosaminidase was evaluated in control cells and RACK1 KD MCs. In non-stimulated RACK1 KD MCs (ShRACK1 cl.12 and ShRACK1 cl.29) the basal level of $\beta$-hexosaminidase release was higher than that seen in non-stimulated UT cells or ShCtrl cells (Fig. 8A inset).

Furthermore, at all time points examined, following antigen stimulation, the percentage of $\beta$ hexosaminidase activity released was increased on average 1.8 fold in both clones of RACK1 KD MCs in comparison with UT and ShCtrl cells (Fig. 8A). RACK1 KD MCs also released 
258

259

260

261

262

263

264

265

266

267

268

269

270

271

272

273

274

275

much more rapidly. The amount of $\beta$-hexosaminidase released by RACK1 KD MCs 5 min after antigen stimulation was similar to that released by ShCtrl cells $60 \mathrm{~min}$ after antigen stimulation (Fig. 8A). Antigen stimulated degranulation was also increased (1.45 fold) in BMMCs knocked down for RACK1 when compared to ShCtrl cells (Supplemental Fig. 3).

RACK1 knockdown did not alter either the total $\beta$-hexosaminidase activity or the expression of Fc\&RI on the cell surface (Supplemental Fig. 4).To determine if activation via FceRI was essential for stimulation of degranulation in RACK1 KD MCs, the cells were activated independently of FceRI with thapsigargin (TG) (Christensen et al., 1993) or with calcium ionophore (Pressman, 1976). Both TG (Fig. 8B) and calcium ionophore (Fig. 8C) increased degranulation of RACK1 KD MCs, demonstrating that involvement of FceRI was not necessary to increase stimulus induced degranulation.

Released $\beta$-hexosaminidase activity was also evaluated in ShCtrl cells pretreated with LatB $(\mathrm{ShCtrl}+\mathrm{LatB})$. LatB treatment resulted in a significant increase in $\beta$-hexosaminidase release in non-stimulated cells (Fig. 8A inset) as well as an increased $\beta$-hexosaminidase release following antigen stimulation (Fig. 8A). Additionally, ShCtrl + LatB cells demonstrated significantly higher $\beta$-hexosaminidase release when activated with TG (Fig. 8B) or with calcium ionophore (Fig. 8C) when compared with ShCtrl cells. However, the response was similar compared with ShRACK1 KD MCs. 
A

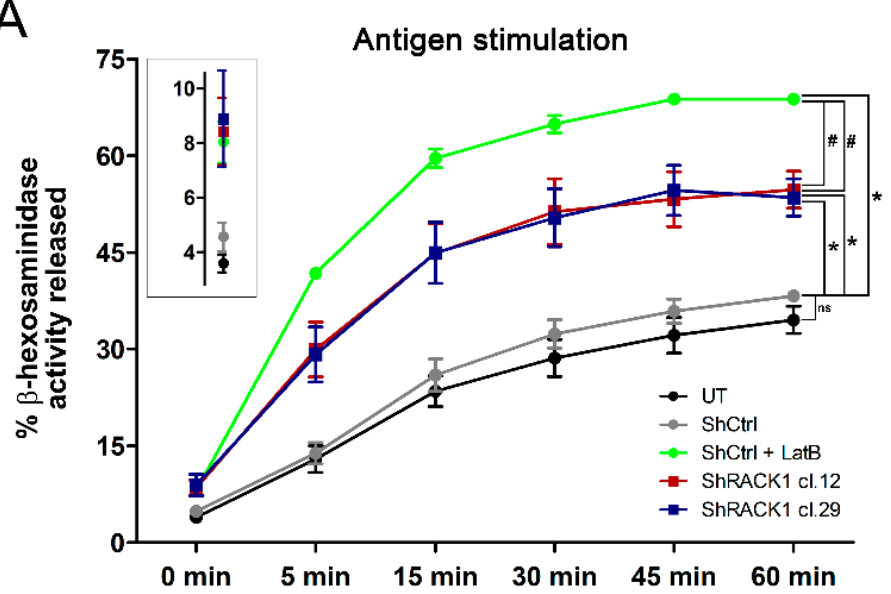

B

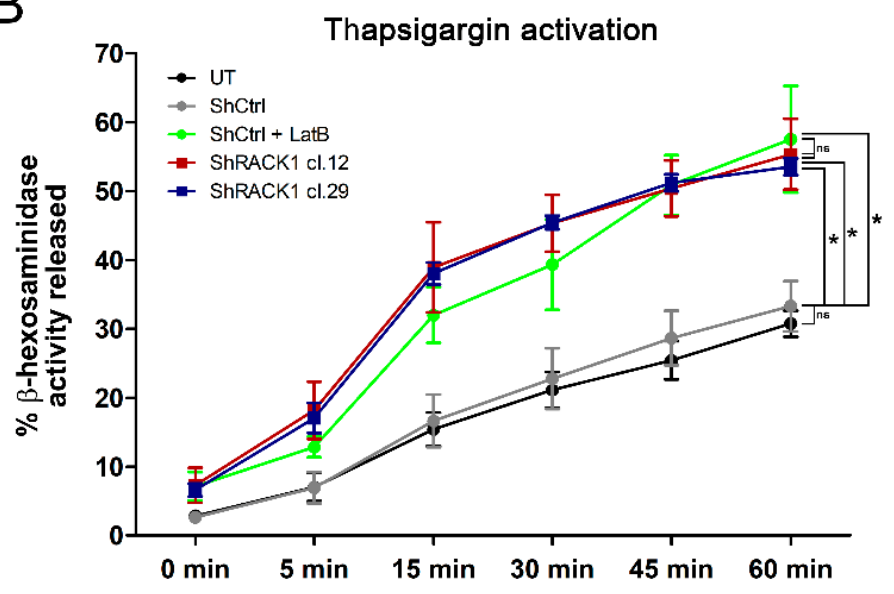

C

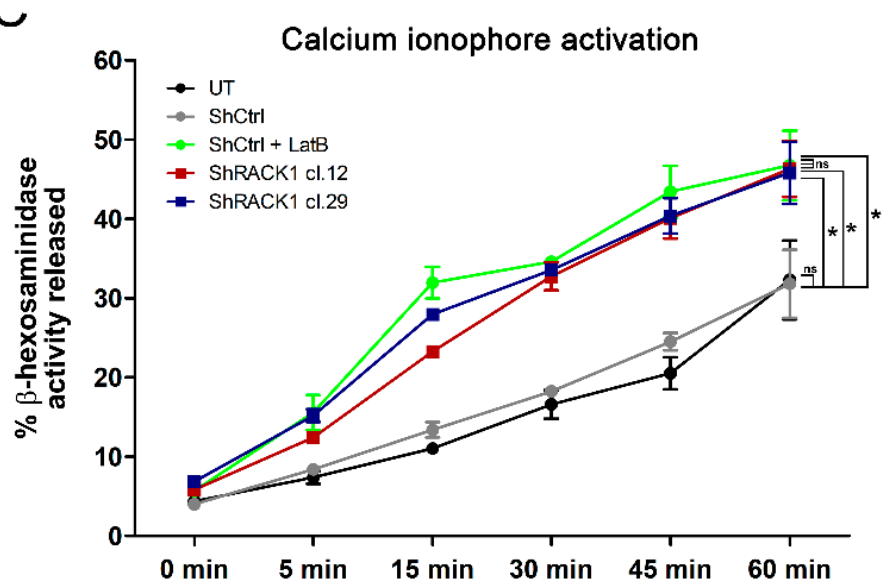

Figure 8. RACK1 knockdown results in an increased release of $\beta$-hexosaminidase activity. The activity of released $\beta$-hexosaminidase was determined from non-stimulated cells $(0 \mathrm{~min})$ and cells stimulated for 5 to $60 \mathrm{~min}$ in untransduced RBL-2H3 MCs (UT), cells transduced with control shRNA (ShCtrl), cells transduced with RACK1 shRNAs (ShRACK1 cl.12 and ShRACK1 cl.29), and control shRNA transduced cells pretreated with 0.5 $\mu \mathrm{M}$ latrunculin B (ShCtrl + LatB). (A) For antigen stimulation via FceRI, cells were sensitized or not with IgE anti-TNP and stimulated via FceRI with $50 \mathrm{ng} / \mathrm{mL} \mathrm{DNP}_{54}$-HSA. Inset: values for the non-stimulated time point $(0$ min) on an expanded scale. (B) Cells were activated or not with $1 \mu \mathrm{M} \mathrm{TG}$ and the activity of $\beta$-hexosaminidase released was determined. (C) Cells were activated or not with $0.1 \mu \mathrm{g} / \mathrm{mL}$ calcium ionophore and the activity of $\beta$ hexosaminidase released was determined. Data are expressed as the mean \pm SEM of a minimum of five independent experiments. ${ }^{*} \mathrm{p}<0.01$ vs. ShCtrl for all time points. \#p $<0.01 \mathrm{ShCtrl}+\mathrm{LatB}$ cells $v s$ ShRACK1 cl.12 and cl.29. ns: not significant. 
Cortical F-actin acts as a barrier preventing the fusion of the SGs with the plasma membrane and consequently preformed mediator release in resting MCs (Frigeri and Apgar, 1999; Nishida et al., 2005). Since RACK1 appears to play a key role in both cortical F-actin integrity and degranulation, it was of interest to determine if SGs could be detected in cortical F-actin free regions seen in RACK1 KD MCs. Cells were immunostained with an anti-CD63 to label SGs and stained with phalloidin conjugated with Alexa 488. In non-stimulated control cells (UT and ShCtrl), CD63 ${ }^{+}$SGs are dispersed throughout the cytoplasm and in the juxtanuclear region, while cortical F-actin forms a continuous layer under the plasma membrane (Fig. 9A). In contrast, in non-stimulated RACK1 KD MCs (ShRACK1 cl.29) or ShCtrl cells pretreated with LatB (ShCtrl + LatB) SGs are aggregated and closer to the surface and the cortical F-actin is discontinuous (Fig. 9A). Three-dimensional reconstruction of $\mathrm{z}$ stacks from the confocal images demonstrated relationship of the SGs with the cortical Factin. In non-stimulated control cells (UT and ShCtrl), there was a barrier of F-actin at the cells surface, and very few SGs could be seen in the 3D reconstructions (Fig. 9B). In contrast, in the non-stimulated RACK1 KD MCs there were cortical F-actin free regions with SGs present in these actin free areas. In non-stimulated ShCtrl + LatB cells the distribution of Factin and SGs was similar to that seen in the non-stimulated RACK1 KD MCs (Fig. 9B). When the control cells (UT and ShCtrl) were antigen stimulated for 5 min the SGs moved closer to cell surface and cortical F-actin is now partially disrupted (Fig. 9C). However, the stimulated RACK1 KD MCs or ShCtrl + LatB had fewer SGs and some of them can be seen intercalated with the cortical F-actin (Fig. 9C). 

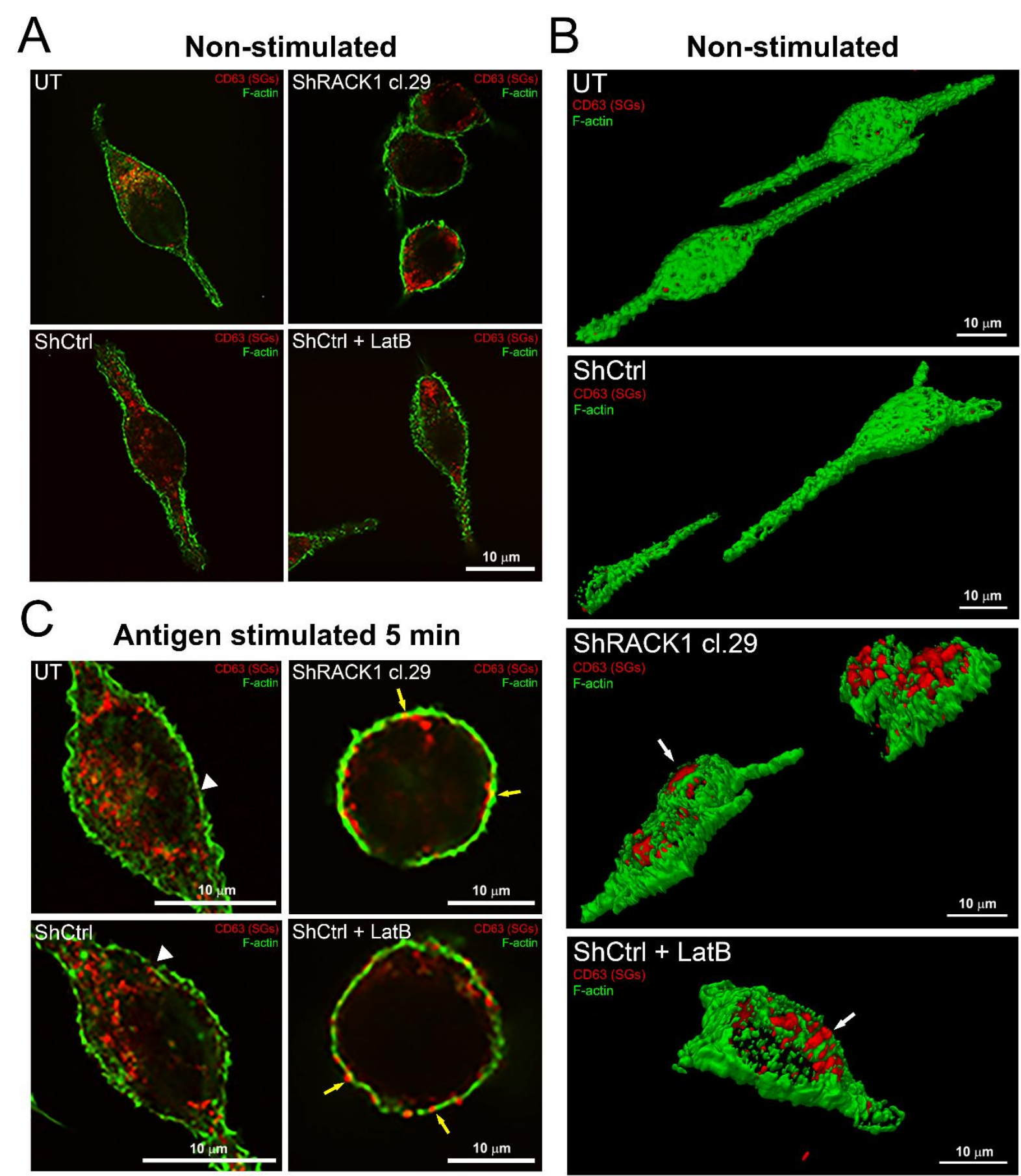

Figure 9. $\mathrm{CD63}^{+}$secretory granules localize at cortical F-actin free regions in RACK1 knockdown mast cells.

The secretory granules (SGs) were immunolabeled with anti-CD63 followed by the secondary antibody anti-mouse IgG conjugated with Alexa 594 (red) and F-actin was stained with phalloidin conjugated with Alexa 488 (green) in untransduced RBL-2H3 MCs (UT), control shRNA transduced cells (ShCtrl), RACK1 KD MCs (ShRACK1 cl.29), and pretreated ShCtrl cells with $0.5 \mu \mathrm{M}$ latrunculin B (ShCtrl + LatB). For antigen stimulation, cells were sensitized with IgE anti-TNP and stimulated via FceRI with $50 \mathrm{ng} / \mathrm{mL} \mathrm{DNP} 54-\mathrm{HSA}$ for $5 \mathrm{~min}$. (A) Single Z section of non-stimulated cells obtained using a Nikon Eclipse Ti2-E A1 high resolution microscope. (B) Images acquired by scanning confocal microscopy were analyzed with LA-X software and plug-in 3D viewer (modes of volume, blend and surface). White arrow: $\mathrm{CD}^{+} 3^{+} \mathrm{SG}$ clustering in F-actin free cortical regions. (C) Single Z section of cells antigen stimulated for 5 min obtained using a Nikon Eclipse Ti2-E A1 high resolution microscope. Arrowheads: partially disrupted cortical F-actin. Yellow arrow: SGs intercalated with cortical F-actin. Images are representative of three independent experiments. 
To determine if RACK1 also participates in release of newly formed and newly synthetized mediators following antigen stimulation, cell media was collected and tested for the presence of some lipid mediators and cytokines. The release of PGD2 and LTC4, although reduced, was not significantly affected by RACK1 depletion (Fig. 10A-B). However, in contrast to the observed increased degranulation, the secretion of a number of cytokines, including IL-4, IL-1 $\beta$, MIP-1 and $3 \alpha$, IL-3, IL-10 and IL-13 was substantially reduced in RACK1 KD MCs compared to control ShCtrl cells (Fig. 10C). These results indicate that RACK1 is also involved in the release of newly synthetized mediators.

A

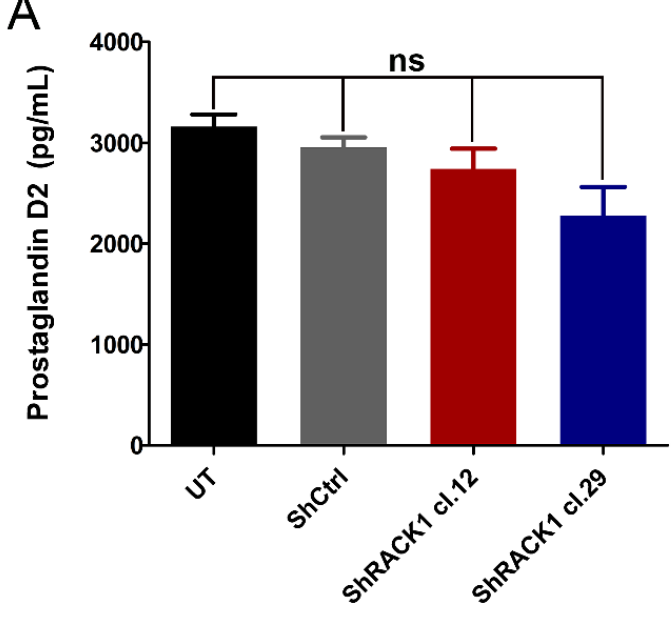

B

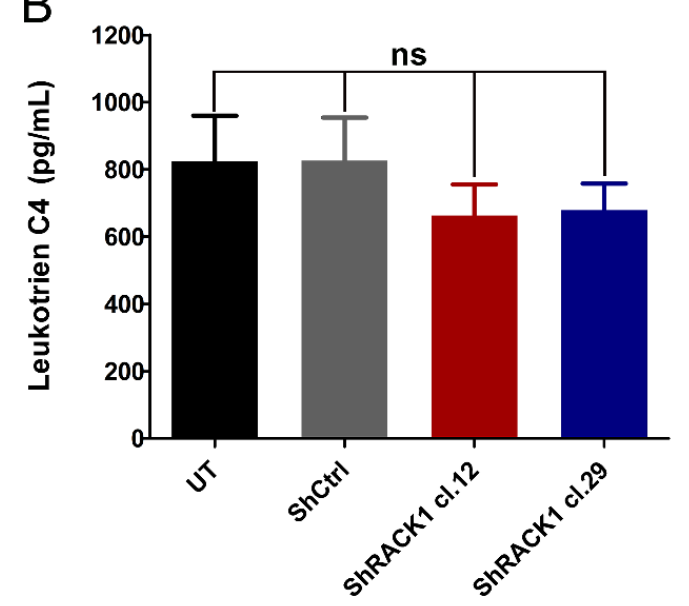

C
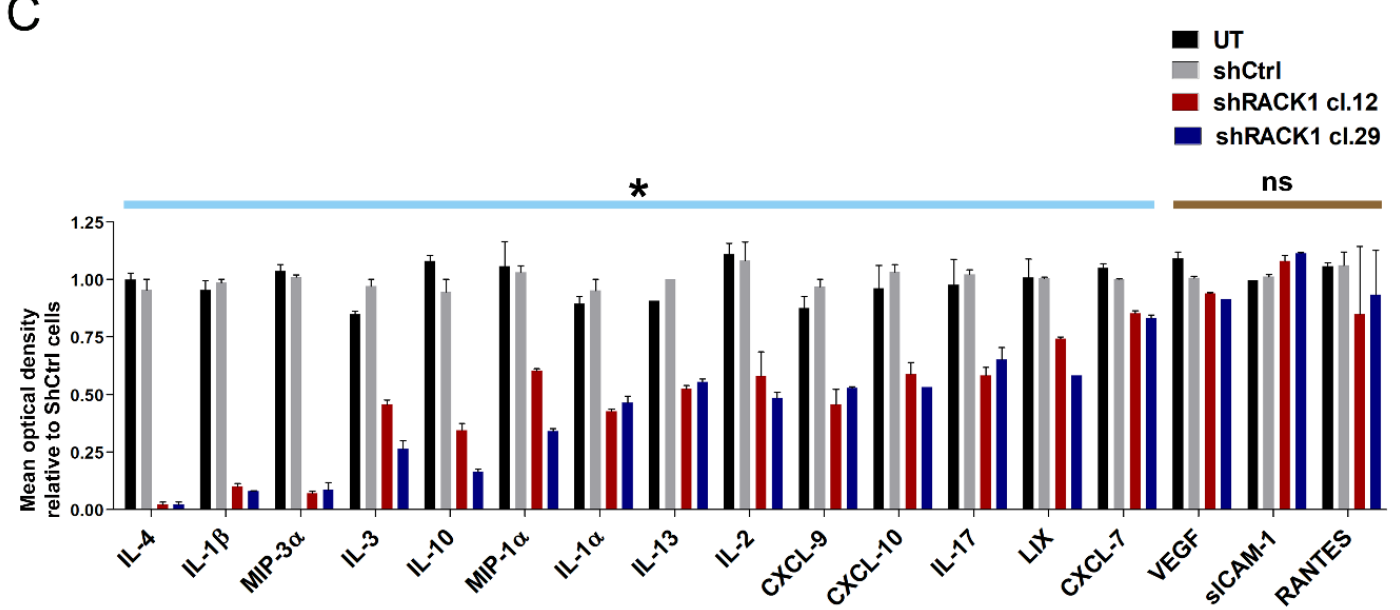

Figure 10. shRNA mediated depletion of RACK1 does not affect newly formed lipid mediators by impaired cytokine secretion. Newly formed and newly synthesized mediators were measured in culture supernatants of cells sensitized with IgE anti-TNP and stimulated via FceRI with $50 \mathrm{ng} / \mathrm{mL} \mathrm{DNP}_{54}$-HSA for, respectively, $30 \mathrm{~min}$ and 24 h. (A) Prostaglandin D2 (PGD2) and (B) Leukotriene C4 (LTC4) were determined by EIA. Data are expressed as the mean \pm SEM of three independent experiments. (C) The Proteome Profiler ${ }^{\mathrm{TM}}-$ Rat Cytokine Array Panel A - was used to simultaneously assess the relative levels of 29 cytokines secreted in the culture media of antigen stimulated cells. Data is expressed as SEM of the mean pixel density normalized relative to ShCtrl cells from three independent experiments. The mean pixel densities of the spots for each cytokine in the membrane array were quantified using ImageJ. The 17 cytokines whose secretion were detected is shown. The comparation between ShCtrl and UT was not significant. Light blue bar: *p<0.05 ShCtrl vs ShRACK1 cl.12 and ShRACK1 cl.29. Brown bar: not significant (ns). UT: untransduced RBL-2H3 MCs; ShCtrl: cells transduced with control shRNA; ShRACK1 cl.12: cells transduced with RACK1 cl.12 shRNA; ShRACK1 cl.29: cells transduced with RACK1 cl.29 shRNA. 


\section{RACK1 regulates calcium mobilization induced by antigen stimulation or thapsigargin activation}

Since actin polymerization/depolymerization as well as MC mediator release following stimulation via FceRI is calcium dependent (Di Capite et al., 2011; Wollman and Meyer, 2012), the effect of RACK1 knockdown on the calcium response following FceRI activation in RBL-2H3 MCs was examined. Initially, cells were antigen stimulated in $\mathrm{Ca}^{2+}$-containing media and the individual cellular response for each cell type was averaged. Following stimulation, the levels of $\left[\mathrm{Ca}^{2+}\right]_{\mathrm{i}}$ between control cells (UT and ShCtrl) and RACK1 KD MCs (ShRACK1 cl.12 and ShRACK1 cl.29) differed. The antigen-induced increase in $\left[\mathrm{Ca}^{2+}\right]_{\mathrm{i}}$ was significantly higher in the RACK1 KD MCs, especially at later times after stimulation (Fig. 11A and Supplemental Fig. 5A).

The involvement of RACK1 in the two main events of SOCE triggered by FceRI activation was then investigated. The $\mathrm{Ca}^{2+}$ response after antigen stimulation in absence and then in presence of extracellular $\mathrm{Ca}^{2+}$ was compared. After stimulation in the absence of $\mathrm{Ca}^{2+}$, control cells (UT and ShCtrl) showed a transient peak in $\left[\mathrm{Ca}^{2+}\right]_{i}$ that with time returned to basal levels. In contrast, in RACK1 KD MCs (ShRACK1 cl.12 and ShRACK1 cl.29) this transient peak was lower (Fig. 11B and Supplemental Fig. 5B release). After replacement of the extracellular $\mathrm{Ca}^{2+}\left(1 \mathrm{mM} \mathrm{CaCl}_{2}\right)$ at $~ 200$ s post stimulation, the $\mathrm{Ca}^{2+}$ influx in RACK1 KD MCs was lower in comparison to control cells (UT and ShCtrl) (Fig. 11B and Supplemental Fig. 5B influx). These results suggest that RACK1 has an important role in FceRI-stimulated depletion of $\mathrm{Ca}^{2+}$ from ER stores.

To better evaluate the function of RACK1 in $\mathrm{Ca}^{2+}$ mobilization in MCs, the cells were activated with TG. The response induced by TG stimulation in the presence of extracellular $\mathrm{Ca}^{2+}$ was less in the RACK1 KD cells (ShRACK1 cl.12 and ShRACK1 cl.29) than in the control cells (UT and ShCtrl cells), although the initial rise was similar (Fig. 11C and Supplemental Fig. 5C). This suggested that the TG-dependent intracellular ER store depletion was normal in the RACK1 KD cells, but that $\mathrm{Ca}^{2+}$ influx was defective. To evaluate this possibility, experiments were conducted in the absence of extracellular $\mathrm{Ca}^{2+}$. The initial intracellular $\mathrm{Ca}^{2+}$ response (release of $\mathrm{Ca}^{2+}$ from intracellular $\mathrm{Ca}^{2+} \mathrm{ER}$ stores) induced by TG stimulation was the same for both ShCtrl cells and RACK1 KD cells (Fig. 11D and Supplemental Fig. 5D release). However, when the extracellular $\mathrm{Ca}^{2+}$ was replenished at 200 s post stimulation the RACK1 KD cells showed a diminished $\mathrm{Ca}^{2+}$ influx (Fig. 11D and Supplemental Fig. 5D influx). These findings confirm that RACK1 is involved only in the 
A

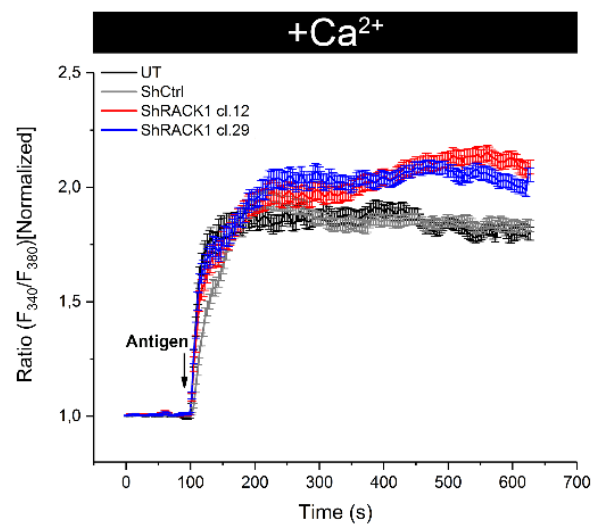

C

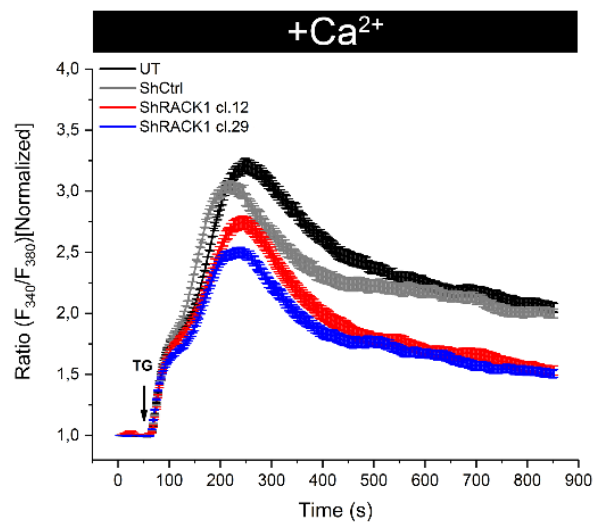

B

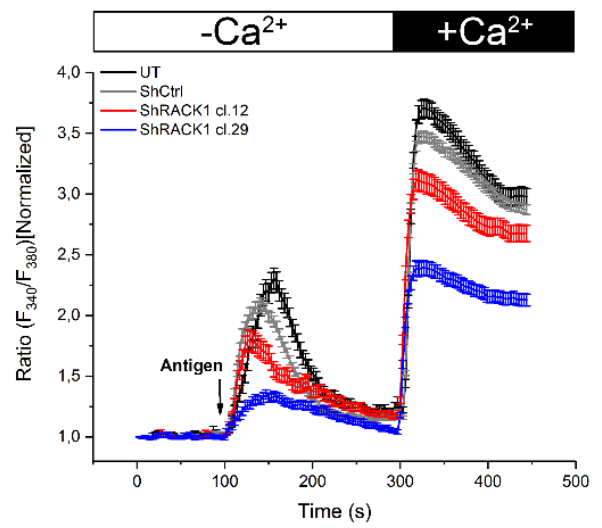

D

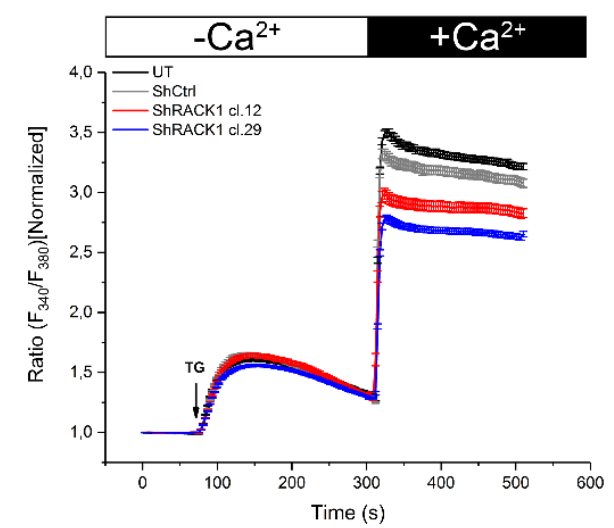

Figure 11. Calcium mobilization is affects in stimulated RACK1 knockdown mast cells. Cells were sensitized or not with IgE anti-TNP, loaded with Fura-2, and stimulated (arrow) with antigen or TG. $\left[\mathrm{Ca}^{2+}\right]_{\mathrm{i}}$ was determined by averaging the ratio of fluorescence intensity when Fura-2 was excited at 340 and $360 \mathrm{~nm}$. (A) Cells were stimulated via FceRI with $50 \mathrm{ng} / \mathrm{mL} \mathrm{DNP}_{54}$-HSA in the presence of extracellular $\mathrm{Ca}^{2+}$. (B) Cells were antigen stimulated in a $\mathrm{Ca}^{2+}$-free solution. At $\sim 200$ s post stimulation, the solution was replenished with media containing $1 \mathrm{mM} \mathrm{CaCl}_{2}$. (C) Cells were activated with $1 \mu \mathrm{M}$ thapsigargin (TG) in the presence of extracellular Ca ${ }^{2+}$. (D) Cells were activated with $1 \mu \mathrm{M}$ TG in a $\mathrm{Ca}^{2+}$-free solution. At $\sim 200 \mathrm{~s}$ post stimulation, $\mathrm{CaCl}_{2}$ was added to a final concentration of $1 \mathrm{mM}$. Black bar: with extracellular $\mathrm{Ca}^{2+}$. White bar: without extracellular $\mathrm{Ca}^{2+}$. A minimum of 348 cells were analyzed for each group of cells. Data are expressed as the mean \pm SEM of at a minimum of three independent experiments. UT: untransduced RBL-2H3 MCs; ShCtrl: cells transduced with control shRNA; ShRACK1 cl.12: cells transduced with RACK1 cl.12 shRNA; ShRACK1 cl.29: cells transduced with RACK1 cl.29 shRNA.

\section{Latrunculin B increases antigen stimulus-induced calcium mobilization}

Since calcium mobilization is increased in antigen stimulated RACK1 KD MCs and the actin cytoskeleton is disorganized in these cells, the possible correlation between these events was investigated. ShCtrl cells were pretreated or not with $0.5 \mathrm{mM}$ LatB and the calcium response induced by antigen stimulation was then analyzed. Initially, cells were stimulated in the presence of extracellular $\mathrm{Ca}^{2+}$. The increase in $\left[\mathrm{Ca}^{2+}\right]_{\mathrm{i}}$ was significantly higher in LatB treated cells (Fig. 12A and Supplemental Fig. 5E). When cells were antigen stimulated in a 
$401 \mathrm{Ca}^{2+}$-free solution, the initial $\left[\mathrm{Ca}^{2+}\right]_{\mathrm{i}}$ response was not significantly different between the non-

402

403

404

405

406

407

408 treated ShCtrl and LatB treated cells. However, the ER-Ca ${ }^{2+}$ release appeared to be slightly earlier and greater in the LatB treated cells (Fig. 12B and Supplemental Fig. 5F release). The replenishment of extracellular $\mathrm{Ca}^{2+}\left(1 \mathrm{mM} \mathrm{CaCl}_{2}\right)$ at $\sim 200 \mathrm{~s}$ resulted in an increased influx of $\mathrm{Ca}^{2+}$ into LatB treated cells (Fig. 12B and Supplemental Fig. 5F influx). Therefore, LatB treatment affects the FceRI-stimulated depletion of ER-Ca ${ }^{2+}$ stores and consequent $\mathrm{Ca}^{2+}$ influx.

A

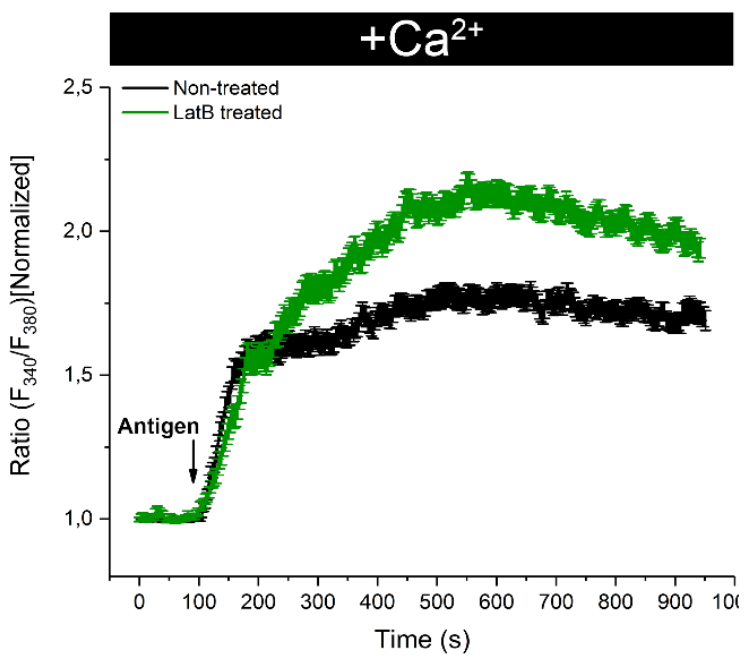

B

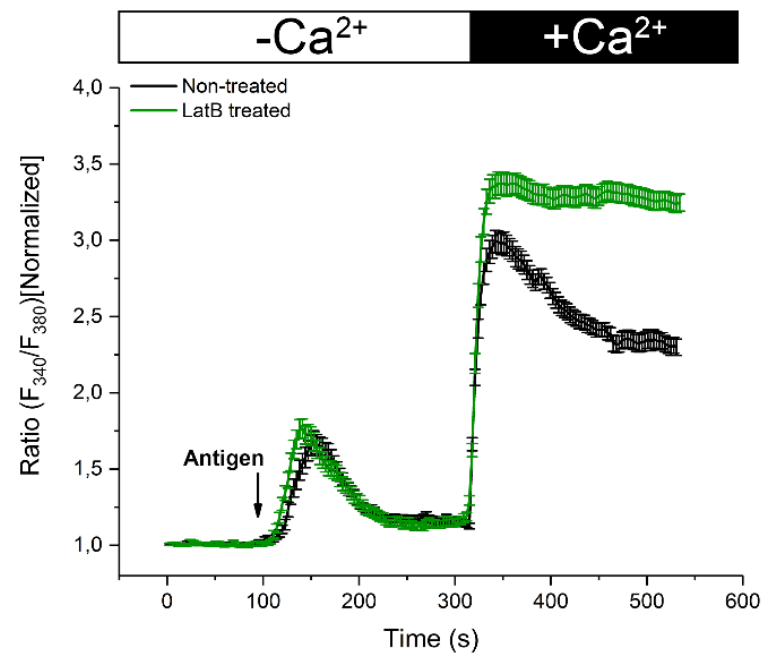

409

Figure 12. Latrunculin $B$ treatment increases calcium mobilization induced by antigen stimulation in mast cells. RBL-2H3 MCs transduced with control shRNA (ShCtrl) were pretreated or not (non-treated) for 15 min with $0.5 \mathrm{mM}$ latrunculin B (LatB treated), loaded with Fura-2, and antigen stimulated via FceRI with $50 \mathrm{ng} / \mathrm{mL} \mathrm{DNP}_{54}$ - $^{-}$ HSA (arrow). $\left[\mathrm{Ca}^{2+}\right]_{\mathrm{i}}$ was determined by averaging the ratio of fluorescence intensity when Fura- 2 was excited at 340 and $360 \mathrm{~nm}$. (A) Cells were stimulated in the presence of extracellular $\mathrm{Ca}^{2+}$. (B) Cells were stimulated in a $\mathrm{Ca}^{2+}$-free solution. At $\sim 200 \mathrm{~s}$ post stimulation, the solution was replenished with media containing $1 \mathrm{mM} \mathrm{CaCl}_{2}$. Black bar: with extracellular $\mathrm{Ca}^{2+}$. White bar: without extracellular $\mathrm{Ca}^{2+}$. A minimum of 263 cells were analyzed for each group of cells. Data are expressed as the mean \pm SEM of a minimum of three independent experiments.

\section{Latrunculin B decreases $\mathrm{Ca}^{2+}$ entry stimulated by thapsigargin}

Since calcium mobilization is defective in RACK1 KD MCs stimulated with TG and the actin cytoskeleton is disorganized in these cells, the possible correlation between these events was investigated. SOCE triggered by TG was then analyzed in ShCtrl cells pretreated or not with LatB. The response induced by TG in the presence of extracellular $\mathrm{Ca}^{2+}$ was less in LatB treated cells than in non-treated ShCtrl cells (Fig. 13A and Supplemental Fig. 5G). In the absence of extracellular $\mathrm{Ca}^{2+}$, the intracellular $\mathrm{Ca}^{2+}$ response was the same for non-treated and LatB treated cells after stimulation with TG (Fig. 13B and Supplemental Fig. 5H release). In contrast, after the replenishment of extracellular $\mathrm{Ca}^{2+}$ at $\sim 200 \mathrm{~s}$ post stimulation there was a decreased influx of $\mathrm{Ca}^{2+}$ in LatB treated cells (Fig. 13B and Supplemental Fig. 5H influx). 
429 Therefore, LatB treatment which results in actin cytoskeleton disarrangement reduces $\mathrm{Ca}^{2+}$ entry trigged by TG.

A

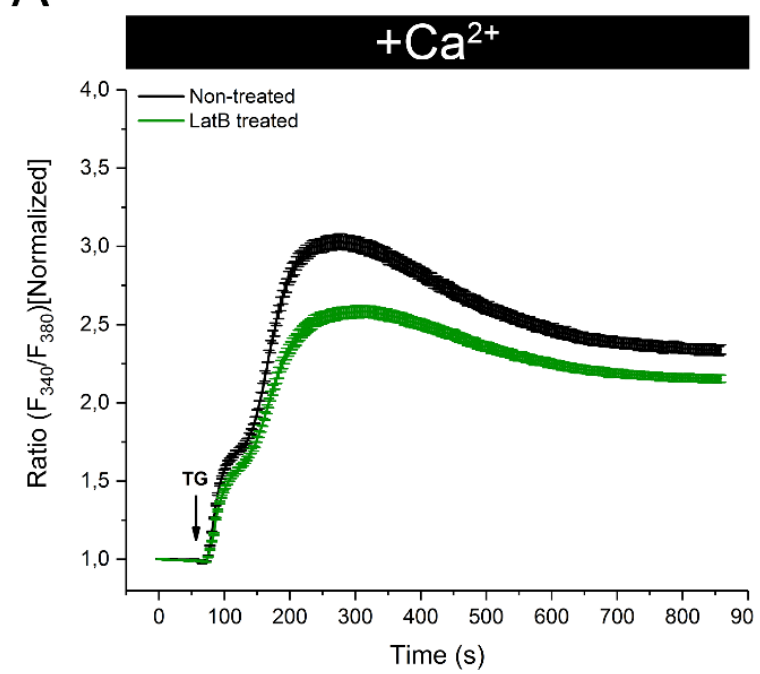

B

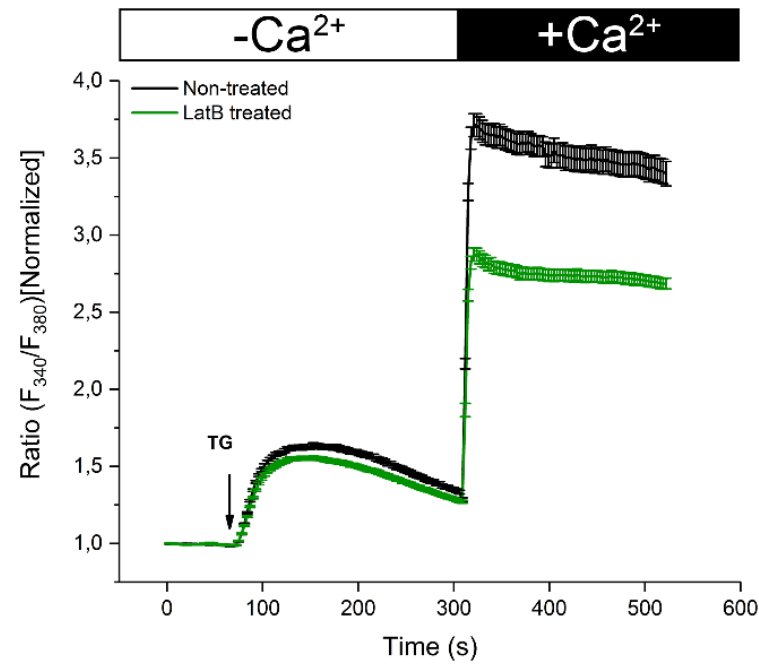

432

433

434

435

436

437

438

439

440

441

442

443

444

445

446

447

448

449

Figure 13. Latrunculin B treatment decreases $\mathbf{C a}^{\mathbf{2 +}}$ entry stimulated by thapsigargin in mast cells. RBL-2H3 MCs transduced with control shRNA (ShCtrl) were pretreated or not (non-treated) for 15 min with $0.5 \mathrm{mM}$ latrunculin B (LatB treated), loaded with Fura-2, and activated with $1 \mu \mathrm{M}$ thapsigargin (TG) (arrow). [Ca $\left.{ }^{2+}\right]_{\mathrm{i}} \mathrm{was}$ determined by averaging the ratio of fluorescence intensity when Fura-2 was excited at 340 and $360 \mathrm{~nm}$. (A) Cells were activated in the presence of extracellular $\mathrm{Ca}^{2+}$. (B) Cells were activated in a $\mathrm{Ca}^{2+}$-free solution. At $\sim 200 \mathrm{~s}$ post stimulation, $\mathrm{CaCl}_{2}$ was added to a final concentration of $1 \mathrm{mM}$. Black bar: with extracellular $\mathrm{Ca}^{2+}$. White bar: without extracellular $\mathrm{Ca}^{2+}$. A minimum of 294 cells were analyzed for each group of cells. Data are expressed as the mean \pm SEM of three independent experiments.

\section{RACK1 binds to the pore-forming component of the CRAC channel Orai1 in an antigen}

\section{stimulus-dependent manner}

Since RACK1 appears to be a multifunctional regulator of calcium mobilization in MCs, it was of interest investigate if the pore subunit of the CRAC channel Orai1, which is involved in $\mathrm{Ca}^{2+}$ influx during SOCE in MCs (Vig et al., 2008), binds to RACK1. In nonstimulated cells Orai1 did not co-precipitate with RACK1. However, following antigen stimulation for 1 min Orail co-precipitated with RACK1. The amount of Orai1 coprecipitating with RACK1 increased approximately fourfold and tenfold after stimulation for $1 \mathrm{~min}$ and $5 \mathrm{~min}$ respectively relative to non-stimulated cells (Fig. 14). 

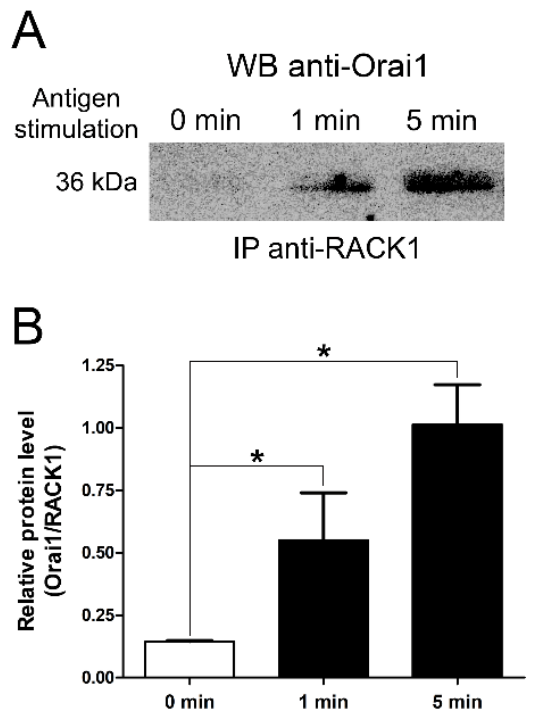

Figure 14. RACK1 co-precipitates with the CRAC channel subunit Orai1 after antigen stimulation. Cells were sensitized or not with IgE anti-TNP and stimulated via FceRI with $50 \mathrm{ng} / \mathrm{mL} \mathrm{DNP}_{54}-\mathrm{HSA}$ or not. RACK1 was immunoprecipitated with rabbit IgG anti-RACK1 from lysates of non-stimulated ( $0 \mathrm{~min})$ and antigen stimulated cells for $1 \mathrm{~min}$ and $5 \mathrm{~min}$. (A) RACK1 immunoprecipitates were blotted with anti-Orai1. (B) The relative amount of co-immunoprecipitated Orai1 was normalized using the amount of RACK1 precipitated. Data is expressed as the mean $\pm \mathrm{SD}$ of three independent experiments. ${ }^{*} \mathrm{p}<0.01$ vs. 0 min. ns: not significant.

\section{Discussion}

This study showed, for the first time, that the scaffold protein RACK1 is expressed in MCs and that RACK1 plays a critical role in the secretion of MC mediators. RACK1 was present in MCs both in vivo and in vitro. In RBL-2H3 MCs, RACK1 was localized throughout the cytoplasm, but there was an increased concentration close to the plasma membrane, and in the juxtanuclear region. This result is in agreement with the localization of RACK1 in other cell types (Adams et al.; Ballek et al.; Neasta et al.). After MC stimulation via FceRI at short time periods, RACK1 was concentrated adjacent to the plasma membrane and in the perinuclear region. RACK1 is compartmentalized at different subcellular sites due to its ability to bind to multiple binding partners. This distribution can be modified in response to external stimuli which results in the translocation of RACK1 to other subcellular sites (Ron et al., 2013). Therefore, the changes in RACK1 distribution induced by antigen stimulation suggest that RACK1 can participate in signal transduction during MC activation.

RACK1 has an important role in maintain cell shape and in the organization of the actin cytoskeleton. After RACK1 depletion, RBL-2H3 MC morphology was profoundly affected. SEM images and morphometric analysis confirmed that, in contrast to their typical fusiform shape, non-stimulated RACK1 KD MCs were rounded. Our results are in agreement with previous studies which showed that RACK1 is involved in regulating cell shape of cardiomyocytes (O'Donovan et al., 2007), RAT2 fibroblasts (Klímová et al., 2016) and 
neurons (Kershner and Welshhans, 2017). Moreover, actin microfilaments in the cortical region of RACK1 KD cells were fragmented with spaces devoid of F-actin. The spaces in the cortical actin increased after antigen stimulation. This phenotype was similar to that seen in control cells pretreated with LatB. The TIRFM analysis of F-actin dynamics following antigen stimulation showed that the RACK1 KD MCs were defective in organizing the Factin cytoskeleton. RACK1 depletion in RAT2 fibroblasts influences F-actin assembly when the cells break radial symmetry and spread over a fibronectin substrate (Klímová et al., 2016). In contrast, overexpression of RACK1 resulted in an increase in actin stress fibers in Chinese hamster ovary (CHO) cells (Buensuceso et al., 2001).

The involvement of RACK1 in the molecular regulation of the actin cytoskeletal is not well elucidated and appears to be dependent on stimulus and cell type (Duff and Long, 2017). In non-stimulated RBL-2H3 cells, $\beta$-actin immunoprecipitated with RACK1. The amount of $\beta$-actin immunoprecipitating with RACK1 increased after MC antigen stimulation. Diverse studies have shown a role for RACK1 in cytoskeletal organization through its interaction or assembly of signaling complexes containing integral and regulatory cytoskeleton proteins (Duff and Long, 2017; Jia et al., 2013; Klímová et al., 2016; Neasta et al., 2016; Serrels et al., 2011; Wang et al., 2011). LatB treatment of non-stimulated RBL-2H3 MCs significantly increased the $\beta$-actin binding to RACK1. Neasta et al. (2016) previously observed similar results in cortical neurons and showed using purified proteins that RACK1 preferentially binds to $\beta$-actin monomeric forms.

Cortical F-actin dynamics have a significant impact on regulated secretion of preformed mediators stored in SGs (Nishida et al., 2005; Wollman and Meyer, 2012). The 60\% reduction in RACK1 seen in the current study was sufficient to affect the release of the preformed mediator $\beta$-hexosaminidase. RACK1 KD MCs secreted significantly more $\beta$-hexosaminidase both when not stimulated and after FceRI activation. This enhanced $\beta$-hexosaminidase release was not a consequence of variations in the intracellular levels of $\beta$-hexosaminidase or in cell surface expression of FceRI. Moreover ShCtrl + LatB cells also demonstrated an increased basal and FceRI activated degranulation when compared to control or RACK1 KD cells. LatB treatment, in addition to the disruption of F-actin, also increases the early signaling events during FceRI activation (Frigeri and Apgar, 1999; Shelby et al., 2016). This may help explain the increased secretion seen in ShCtrl + LatB MCs. Moreover, degranulation in response to TG or calcium ionophore which act downstream of FceRI was also enhanced in RACK1 KD MCs and ShCtrl + LatB cells. This suggests that RACK1 might be also involved in processes 
511

512

that modulate regulated secretion independent of FceRI, possibly by influencing the organization of the actin cytoskeleton. It has been suggested that RACK1 participates in cortical granule exocytosis in rat eggs by binding to $\mathrm{PKC} \beta \mathrm{II}$ and actin which facilitates the granule translocation towards the egg membrane (Haberman et al., 2011). Other proteins from the same family as RACK1, Coronin $1 \mathrm{a}$ and $1 \mathrm{~b}$ and tomosyn also demonstrated a regulatory role in MC secretion. Coronins and tomosyn both inhibit MC degranulation (Föger et al., 2011; Madera-Salcedo et al., 2018).

The cortical F-actin network acts as a physical barrier to prevent docking and fusion of SGs to the plasma membrane (Aunis and Bader, 1988; Wilson et al., 2016; Wollman and Meyer, 2012). In the present study, the high resolution microscopy and 3D reconstitution confocal images showed in detail the SGs localization in cortical actin-free regions of nonstimulated RACK1 KD cells or ShCtrl + LatB cells. This access of the SGs to the plasma membrane may help explain the high basal secretion by these cells. Moreover, after FceRI activation the release of SG preformed mediators is accelerated. The increased degranulation can be correlated to disruption of the F-actin barrier in RACK KD cells. Therefore, our data indicate RACK1 as an essential negative regulator of MC degranulation due to its role in Factin dynamics.

In contrast, we observed that RACK1 depletion impaired the release of newly synthesized cytokines. This can also be explained, in part, by F-actin disruption. It has been hypothesized that the actin cytoskeleton may exhibit a functional dichotomy in regulating SGs release versus cytokine secretion in MCs (Föger et al., 2011). Actin-dependent processes have been implicated in the regulation of membrane trafficking from the ER and Golgi apparatus to the plasma membrane (Müsch et al., 1997). However, the directly involvement of RACK1 in the intracellular pathways responsible for the synthesis of cytokines has been demonstrated in other immune cells (Corsini et al., 2014; Corsini et al., 2009; Yao et al., 2014), and cannot be ruled out.

Calcium mobilization is important event in MC mediator release (Di Capite et al., 2011). Intracellular $\mathrm{Ca}^{2+}$ levels are important in cytoskeleton rearrangement and triggering the fusion of SGs with the plasma membrane (Holowka et al., 2016). In RACK1 KD cells as well as ShCtrl + LatB cells, there was an increase in $\left[\mathrm{Ca}^{2+}\right]_{\mathrm{i}}$ induced by stimulation via FceRI, which correlated with their higher degranulation. Therefore, the increased preformed mediator release and calcium mobilization during FceRI activation can be explained, at least in part, by the disorganized actin cytoskeleton seen in these cells. RACK1 has been previously described 
as an important modulator of SOCE in agonist-stimulated HEK293 cells (IP 3 generationdependent pathway) (Bandyopadhyay et al., 2008; Patterson et al., 2004). Moreover, RACK1 appears to have an intrinsic role in $\mathrm{ER}_{-} \mathrm{Ca}^{2+}$ store depletion since knockdown of RACK1, in contrast to ShCtrl + LatB cells, resulted in a defective FceRI-activated $\mathrm{Ca}^{2+}$ release from ER stores. In HEK293 cells, RACK1 binds to $\mathrm{IP}_{3}$ Rs and this association enhances $\mathrm{IP}_{3}$-binding affinity to its receptors regulating $\mathrm{Ca}^{2+}$ release from ER stores. This data reinforces the hypothesis of a direct involvement of RACK1 in intracellular ER $\mathrm{Ca}^{2+}$ store depletion in MCs, which is different from that related to F-actin disruption.

The present results also indicates previously unknown role for RACK1 in SOCE induced by TG activation. RACK1 KD cells showed, in contrast to FceRI activation, a decrease in calcium entry after stimulation by TG. A similar response was demonstrated by ShCtrl + LatB cells. Although both RACK1 KD and ShCtrl + LatB cells had a diminished calcium mobilization following TG activation, the increase in $\left[\mathrm{Ca}^{2+}\right]_{\mathrm{i}}$ was sufficient to allow for greater mediator release than control cells. TG blocks $\mathrm{Ca}^{2+}$ reuptake into the ER by specifically inhibiting SERCA (sarco/endoplasmic reticulum $\mathrm{Ca}^{2+}$-ATPase) pumps (Dar and Pecht, 1992), resulting in an increase in $\left[\mathrm{Ca}^{2+}\right]_{i}$ due to a spontaneous loss of $\mathrm{Ca}^{2+}$ from the $\mathrm{IP}_{3}-$ sensitive pool in the ER without stimulating $\mathrm{IP}_{3}$-generation and binding to $\mathrm{IP}_{3} \mathrm{Rs}$ (Christensen et al., 1993). Therefore, RACK1 and/or actin cytoskeleton organization has a profound impact on $\mathrm{Ca}^{2+}$ influx through the plasma membrane independent of $\mathrm{IP}_{3}$ induced $\mathrm{ER} \mathrm{Ca}^{2+}$ release.

The present study demonstrated that the pore-forming component of the CRAC channel Orai1 binds to RACK1 in an antigen-stimulus dependent manner. In contrast, STIM1, responsible for gating Orai1/CRACM1 channels (Baba et al., 2008), did not co-precipitate with RACK1 in MCs (data not shown). RACK1 acts as a scaffold protein in the Orai1-

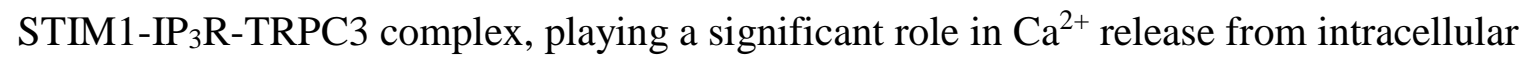
stores and consequent $\mathrm{Ca}^{2+}$ entry in agonist-stimulated HEK293 cells (Bandyopadhyay et al., 2008; Woodard et al., 2010). In MCs stimulated via FceRI, SOCE is induced by the clustering of STIM1 in the ER membrane which then moves into close proximity with the plasma membrane and directly interacts with Orail/CRACM1 channels and TRPC1 (Baba and Kurosaki, 2008; Vig et al., 2008). The results of the present investigation suggest that RACK1, in addition to its association to Orai1, is a novel regulator of stimulus-induced calcium mobilization in MCs.

In conclusion, this study suggests that RACK1 is an essential adaptor for calcium signaling, F-actin dynamics, as they are involved in regulated secretion. The current investigation provides additional information for understanding the molecular mechanisms 
578 involved in MC mediator release under normal and pathophysiological conditions.

579

580

581

582

583

584

585

586

587

588

589

590

591

592

593

594

595

596

597

598

599

600

601

602

603

604

605

606

607

608

609

610

611

\section{METHODS}

\section{Animal}

C57BL/6 mice, 7-8 weeks old, were used in this study. Animals were housed in the Animal Research Facilities of the Ribeirão Preto Medical School, University of São Paulo. The research was conducted in accordance with Ethical Principles in Animal Experimentation adopted by the National Council for Animal Experimentation Control (CONCEA). Experimental protocols were approved by the Ethics Committee on Animal Use (CEUA) of the Ribeirão Preto Medical School (Protocols: 140/2014; 043/2016).

\section{Histology}

The animals were euthanized in a $\mathrm{CO}_{2}$ chamber at a flow rate of $20-30 \% \mathrm{CO}_{2}$ per minute according to Ribeirão Preto Medical School, Ribeirão Preto, Brazil guidelines, and fragments of the right lobe of the lung were collected. Tissues were washed with PBS, fixed in $4 \%$ formaldehyde (EM Sciences, Hatfield, PA) in PBS for $4 \mathrm{~h}$, and embedded in Tissue Freezing Medium (EM Sciences). The samples were then frozen in acetone cooled with dry ice, and stored at $-80^{\circ} \mathrm{C} .12 \mu \mathrm{m}$ sections were cut with a cryostat (Microm GmbH D6900 Heidelberg, West, Germany) and placed on silane-coated Unifrost Microscope Slides (Azer Scientific, Morgantown, PA).

\section{Cell Culture}

In order to obtain BMMCs, the animals were sacrificed as described above and bone marrow cells were obtained by flushing the marrow from the femurs and cultured according to Jamur et al. (2005). The cultures were maintained in suspension for up to 3 weeks.

Human MC line ROSA (KIT D816V) were generously provided by Dr. Olivier Hermine (Laboratory of molecular mechanisms of hematologic disorders and therapeutic implications. Imagine Institute, Paris, France) and maintained in suspension according to Arock et al. (2008) in serum-free MC culture medium (Dulbecco's Minimum Essential Medium IMDM supplemented with $2 \times 10^{-3} \mathrm{~mol} / \mathrm{L}$ L-glutamine, $100 \mathrm{IU} / \mathrm{L}$ penicillin, 100 $\mu \mathrm{g} / \mathrm{L}$ streptomycin, $7.5 \times 10^{-5} \mathrm{M} \beta$-mercaptoethanol, $2 \times 10^{-4} \mathrm{~mol} / \mathrm{L} \mathrm{BSA}, 5 \times 10^{-7} \mathrm{~mol} / \mathrm{L}$ iron-saturated human transferrin, $1.7 \times 10^{-6} \mathrm{~mol} / \mathrm{L}$ insulin, $20 \mathrm{ng} / \mathrm{mL}$ recombinant human stem cell factor).

RBL-2H3 rat MCs (Barsumian et al., 1981) were grown as monolayers in (DMEM) 
612

613

614

615

616

617

618

619

620

621

622

623

624

625

626

627

628

629

630

631

632

633

634

635

636

637

638

639

640

641

642

643

644

645

supplemented with $15 \%$ fetal calf serum and an antibiotic-antimycotic mixture $(100 \mathrm{U} / \mathrm{mL}$ penicillin, $100 \mu \mathrm{g} / \mathrm{mL}$ streptomycin, and $0.25 \mu \mathrm{g} / \mathrm{mL}$ amphotericin $\mathrm{B}$ ).

All reagents used for cell culture were purchased from ThermoFisher Scientific (Thermo Fisher Scientific, Invitrogen, Carlsbad, CA).

\section{Antibodies}

The following primary antibodies and their conjugates were used: rabbit polyclonal anti-mouse mast cell tryptase 6 (mMCP-6) (kindly provided by the late Dr. Michael F. Gurish), mouse monoclonal antibody (mAb) anti-FceRI $\alpha$ subunit conjugated to FITC (Clone BC4; generously provided by Dr. Reuben Siraganian, NIH - NIDCR, Bethesda, MD). Rabbit polyclonal antibody anti-human Orai1 was produced against a C-terminal epitope ELAEFARLQDQLDHRGD and affinity purified by Lofstrand Labs Limited (Gaithersburg, MD). Rabbit mAb anti-human RACK1 (Clone ERP7388; ab129084) and goat polyclonal antibody anti-human RACK1 (ab166796) purchased from Abcam (Cambridge, MA). Rabbit mAb anti-human RACK1 (\#5432), rabbit polyclonal antibody anti-human $\alpha / \beta$-tubulin (\#2148) and mouse mAb anti-human $\beta$-actin (Clone 8H10D10; \#3700) purchased from Cell Signaling (Technology Inc, Beverly, MA). Rabbit mAb anti-mouse GAPDH (G9545) purchased from Millipore Sigma (St. Louis, MO). Mouse mAb anti-rat CD63 (Clone AD1; 551458) purchased from BD Biosciences Pharmingen (San Jose, CA).

The secondary antibody donkey anti-rabbit IgG conjugated to horseradish peroxidase (HRP) and donkey anti-mouse IgG conjugated to HRP were used for immunoblotting (Jackson ImmunoResearch Laboratories Inc., West Grove, PA). The following secondary antibodies were used for immunofluorescence: donkey anti-rabbit IgG F(ab)' ${ }_{2}$-Alexa 488 or 594; donkey anti-goat IgG F(ab) 2-Alexa 594; donkey anti-mouse IgG F(ab) 2-Alexa 594 (ThermoFisher Scientific).

\section{RACK1 shRNA knockdown}

MISSION $^{\circledR}$ lentiviral transduction particles encoding RACK1 shRNA were designed against the following target sequences: Clone 12 (ShRACK1 cl.12) 5'-

TCTGGCTAACTGCAAGCTAAA-3’ (Catalog No. TRCN0000012702) and Clone 29 (ShRACK1 cl.29) 5’-TCTGGCTAACTGCAAGCTAAA-3' (Catalog No.

TRCN0000294547). A control shRNA (ShCtrl) were also used, the MISSION TRC2 pLKO.5-puro Non-Mammalian with the Insert Sequence: 5'- 
646 TT-3' (Catalog No. SHC202). All of these contained a puromycin resistance gene and were

647 purchased from Millipore Sigma.

648 RBL-2H3 MCs and BMMCs were transduced with control or the two premade

649 lentivirus particles encoding RACK1 shRNAs for $16 \mathrm{~h}$ or $48 \mathrm{~h}$, respectively, at a MOI of 6.

650 The media containing the virus was removed and replaced with fresh media and the cells

651 cultured for $24 \mathrm{~h}$ before addition of puromycin (1-3 $\mu \mathrm{g} / \mathrm{mL}$; Millipore Sigma) in order to

652 select for cells in which the shRNA was integrated. Real time PCR and immunoblotting were

653 employed to monitor RACK1 mRNA and protein expression, respectively.

654

655

Real-time PCR and flow cytometry

656

657

For real-time PCR experiments, total RNA was purified from $5.0 \times 10^{6}$ cells using the Illustra $^{\text {TM }}$ RNAspin Mini Isolation Kit (GE Healthcare Life Sciences, Chicago, Illinois) according to the manufacturer's instructions. For cDNA synthesis, $5 \mu \mathrm{g}$ of total RNA was reverse-transcribed using the GoScript ${ }^{\mathrm{TM}}$ Reverse Transcription System according to the manufacturer's instructions (Promega Co., Madison, WI). Gene specific primers were used for quantitative PCR analysis. Power SYBR Green PCR Master Mix (Thermo Fisher Scientific) was used with $10 \mathrm{ng}$ of RNA/well of the cDNA product in an ABI 7500 Real Time PCR System (Thermo Fisher Scientific). For all RT-PCR analysis, GAPDH mRNA was used to normalize RNA inputs. Primer sequences are as follows:

rat RACK1 forward (5'-GTGCTCTTCGAGGTCACTCC-3'); rat RACK1 reverse (5'-CGGTTGTCAGAGGAGAAAGC-3’); rat $\beta$-actin forward (5'-GCATTGCTGACAGGATGCAG-3'); rat $\beta$-actin reverse (5'-GTAACAGTCCGCCTAGAAGCA-3’); rat GAPDH forward (5'-ATGACTCTACCCACGGCAAG-3'); rat GAPDH reverse (5'-CTGGAAGATGGTGATGGGTT-3').

For flow cytometry, the cells were cultivated $\left(5.0 \times 10^{5}\right.$ cells $)$ for $16 \mathrm{~h}$, harvested with

673 non-permeabilized cells were incubated at $4^{\circ} \mathrm{C}$ for $1 \mathrm{~h}$ with mAb BC4-FITC in PBS containing 1\% BSA and $5 \mathrm{mg} / \mathrm{mL}$ normal donkey IgG (Jackson ImmunoResearch), washed in PBS, and fixed for 20 min with $2 \%$ paraformaldehyde before been analyzed with a Guava 


\section{Mast cell activation}

For antigen stimulation, RBL-2H3 MCs and BMMCs were sensitized overnight (ON) with mouse IgE anti-TNP ascites fluid (1:5,000, generously provided by Dr. Reuben Siraganian) and then stimulated via FceRI with $50 \mathrm{ng} / \mathrm{mL}$ of $\mathrm{DNP}_{54}-\mathrm{HSA}$. For FceRI independent stimulation, cells were incubated with $1 \mu \mathrm{M}$ TG or $0.1 \mu \mathrm{g} / \mathrm{mL}$ calcium ionophore A23187. For some experiments, the cells were treated with $0.5 \mu \mathrm{M}$ latrunculin B (LatB) for $15 \mathrm{~min}$ at $37^{\circ} \mathrm{C}$ prior to stimulation and the same concentration of LatB was maintained in the media during all stimulations. All reagents were purchased from Millipore Sigma.

\section{Fluorescence microscopy}

Cryosections from lung were rinsed in PBS and incubated with Image-iT FX Signal Enhancer (ThermoFisher Scientific) for $30 \mathrm{~min}$ at room temperature (RT). Next, sections were rinsed in PBS and incubated for $45 \mathrm{~min}$ at RT in PBS containing 0.5\% BSA and normal donkey IgG ( $5 \mu \mathrm{g} / \mathrm{mL}$; Jackson ImmunoResearch). Lung sections were labeled with primary antibodies diluted in PBS ON at $4^{\circ} \mathrm{C}$. Then, sections were rinsed thoroughly in PBS and incubated for $45 \mathrm{~min}$ at RT with the secondary antibodies diluted in PBS. Sections were then rinsed, and coverslip mounted with Fluoromount-G (EM Sciences).

RBL-2H3 MCs were plated (4.0×10 4 cells/coverslip) on $13 \mathrm{~mm}$ round coverslips, sensitized or not with IgE anti-TNP and cultured for $16 \mathrm{~h}$. BMMCs were plated $\left(5.0 \times 10^{4}\right.$ cells/coverslip) on $13 \mathrm{~mm}$ round coverslips treated with Corning® Cell-Tak Cell and Tissue Adhesive (Corning Incorporated - Life Sciences, Oneonta, NY). The cells were stimulated or not via FceRI, rinsed in PBS and fixed for 20 min with 2-4\% paraformaldehyde (EM Sciences) in PBS at RT. Cells were permeabilized with 0.01\% saponin (Millipore Sigma) in PBS for 30 min, or with 0.3\% triton X-100 (Millipore Sigma) for $10 \mathrm{~min}$ at RT. Next, cells were rinsed twice in PBS and incubated for $45 \mathrm{~min}$ at RT in PBS containing $1 \%$ BSA and $5 \mu \mathrm{g} / \mathrm{mL}$ of normal donkey IgG. Cells were labeled with primary antibodies diluted in PBS containing $1 \%$ BSA for $1 \mathrm{~h}$ at RT. Next, cells were rinsed thoroughly in PBS and incubated for $30 \mathrm{~min}$ at RT with the secondary antibodies diluted in PBS. For F-actin staining, it was used 2.6 U/mL Phalloidin conjugated with Alexa 488 (ThermoFisher Scientific) in addition with the secondary antibodies. Cells were then rinsed in PBS and mounted on glass slides with Fluoromount-G (EM Sciences). Cells incubated without primary antibody served as controls and were all negative. Samples were analyzed using a Zeiss LSM 780 laser scanning confocal microscope (Carl Zeiss, Heidelberg, Germany) or a LEICA TCS-NT SP5 laser 
scanning confocal microscope (Leica Microsystems; Heidelberg, Germany). The high resolution images were acquired using a Nikon Eclipse Ti2-E A1 high resolution microscope (Nikon Instruments Inc., Melville, NY).

The imagens obtained in the SP5 confocal microscope were analyzed using the Leica Application Suite X software (LAS X; Leica Microsystems). ImageJ (Schindelin et al., 2012) was used to determine roundness index and cell area (Schober et al., 2009).

\section{Western Blotting and co-immunoprecipitation}

RBL-2H3 MCs ( $7 \times 10^{5}$ cells) were lysed as previously described (Freitas-Filho et al., 2016). Briefly, cells were washed twice with ice cold PBS and immediately lysed with triple detergent lysis buffer (Jamur and Oliver, 1996) [(50 mM Tris-HCl pH 8, $150 \mathrm{mM} \mathrm{NaCl,} \mathrm{0.1 \%}$ SDS, $1 \%$ Nonidet-P40, $0.5 \%$ sodium deoxycholate), containing $15 \mu \mathrm{L} / \mathrm{mL}$ of protease inhibitor (ThermoFisher Scientific) and $10 \mu \mathrm{L} / \mathrm{mL}$ of phosphatase inhibitor cocktail (ThermoFisher Scientific)], and removed from the flasks by scraping. For immunoblotting, the lysates were sonicated, centrifuged, and the supernatants collected. The protein content was quantified using the Bradford reagent (Millipore Sigma), and BSA was used as a standard (Bradford, 1976). Lysate containing $20 \mu \mathrm{g}$ of protein was mixed with NuPAGE ${ }^{\circledR}$ LDS Sample Buffer (ThermoFisher Scientific), boiled, and the proteins were separated electrophoretically on NuPAGE ${ }^{\circledR} 4-12 \%$ Bis-Tris Protein Gels (ThermoFisher Scientific) and transferred to PVDF membranes using Trans-Blot ${ }^{\circledR}$ TurboTM Transfer System RTA Transfer Kits (Bio-Rad Laboratories, Hercules, CA). After transfer, the membranes were blocked for $1 \mathrm{~h}$ at RT in TTBS (0.05 M Tris-HCl, $0.15 \mathrm{M} \mathrm{NaCl}, \mathrm{pH} 7.5$, and $0.05 \%$ Tween 20$)$ containing $4 \%$ BSA or $5 \%$ nonfat dry milk (Bio-Rad). After blocking, the membranes were incubated $\mathrm{ON}$ at $4^{\circ} \mathrm{C}$ or 1 $h$ at RT with the individual primary antibodies diluted in TTBS. The membranes were then washed, incubated for $30 \mathrm{~min}$ at RT with the appropriate anti-IgG conjugated to HRP, washed and developed using SuperSignal ${ }^{\mathrm{TM}}$ West Pico Plus Chemiluminescent Substrate (Thermo Fisher Scientific). The images were obtained by exposing the membranes to X-ray film (Carestream ${ }^{\circledR}$ Kodak $^{\circledR}$ BioMax ${ }^{\circledR}$ MR film) or with ImageQuant LAS 4000 (GE Healthcare Life Sciences). After exposure, the films were digitized with a HP Scanjet 200 scanner (Barueri, São Paulo, Brazil). The mean optical density of the target protein was determined using ImageJ (Schindelin et al., 2012). For stripping, after the first immunoblotting, the membrane was immersed in Restore ${ }^{\mathrm{TM}}$ Western Blot Stripping Buffer (ThermoFisher Scientific) for $15 \mathrm{~min}$ at RT, washed, and the immunobloting was repeated as above. 
For RACK1 immunoprecipitation, lysates were obtained from RBL-2H3 MCs $\left(4.5 \times 10^{6}\right)$ sensitized or not with IgE anti-TNP, and stimulated or not via FceRI for 1 and 5 min, using Pierce IP Lysis Buffer (ThermoFisher Scientific), containing $15 \mu \mathrm{L} / \mathrm{mL}$ of protease inhibitor and $10 \mu \mathrm{L} / \mathrm{mL}$ of phosphatase inhibitor cocktail. Cells were then removed from the flasks by scraping. The samples were placed on ice for $10 \mathrm{~min}$, vortexed, centrifuged, and the supernatants collected. One mg of protein was precleared by incubation with a portion of prepared beads for $3 \mathrm{~h}$, centrifuged and the supernatant collected. Then, the samples were incubated with rabbit mAb anti-human RACK1 (Cell Signaling Technology Inc.) for $1 \mathrm{~h}$ at $4^{\circ} \mathrm{C}$ with rotation. Next, the immunocomplexes were incubated $\mathrm{ON}$ with protein $\mathrm{A}$ beads (GE Healthcare Life Sciences). The samples were then washed by centrifugation in cold TTBS and boiled in NuPAGE ${ }^{\circledR}$ LDS Sample Buffer with 0.1 M DTT (ThermoFisher Scientific). The RACK1 immunoprecipitates were subjected to electrophoresis, transfer system, and immunoblotted as previously described.

\section{TIRF microscopy}

To evaluate the influence of RACK1 on cortical F-actin dynamics, transduced shRNA RBL-2H3 MCs were electroporated to transiently express LifeAct-RFP (pCMV-LifeAct@TagRFP; IBIDI, Martinsried, Germany) using an Amaxa ${ }^{\circledR}$ Nucleofector ${ }^{\circledR}$ (Lonza, Allendale, NJ) following the manufacturer's instructions (kit T, program X001) and plated in $35 \mathrm{~mm}$ No. 1.0 collagen-coated glass-bottomed culture dishes (Mat Tek Corporation, Ashland, MA). After $24 \mathrm{~h}$, cells were sensitized or not with IgE anti-TNP for $16 \mathrm{~h}$ and then stimulated via FceRI. Live cell TIRF images were acquired using an Olympus IX81 motorized inverted microscope (Olympus, Center Valley, PA) using a $568 \mathrm{~nm}$ laser for excitation of RFP, a TIRF-optimized Olympus Plan APO 60x (1.45 NA) oil immersion objective and Lambda 103 filter wheel (Sutter Instruments, Novato, CA) containing the 575lp filter for emission. Images were collected using a Hamamatsu ORCA-Flash4.0 camera (Olympus) and MetaMorph imaging software (Molecular Devices, San Jose, CA).

\section{Scanning electron Microscopy}

RBL-2H3 MCs were plated on $13 \mathrm{~mm}$ round coverslips $\left(5.0 \times 10^{4}\right.$ cells/coverslip). Cells were rinsed in warm PBS $\left(37^{\circ} \mathrm{C}\right)$ and fixed with $2 \%$ glutaraldehyde (EM Sciences) in warm PBS for $2 \mathrm{~h}$ at RT. Cells were post fixed in $1 \% \mathrm{OsO}_{4}$ (EM Sciences) for $2 \mathrm{~h}$, rinsed in Milli-Q water, incubated with a saturated solution of thiocarbohydrazide (EM), followed by $1 \% \mathrm{OsO}_{4}$. This step was repeated once. The cells were dehydrated in a graded series of ethanol and 
critically point-dried with liquid $\mathrm{CO}_{2}$ in a Tousimis Autosandri-810 (Tousimis Research Co., Rockville, MD), mounted on aluminum stubs with silver paint (EM Sciences), and coated with gold in a BAL-TEC SCD 050 Sputter Coater (BAL-TEC). Samples were examined with a JEOL JSM-6610 LV scanning electron microscope (JEOL Ltd., Tokyo, Japan).

\section{$\beta$-hexosaminidase, newly formed lipid mediator, and newly synthesized cytokine release assay}

MC degranulation was assessed by measuring the activity of $\beta$-hexosaminidase released. RBL-2H3 MCs $\left(3.0 \times 10^{4}\right.$ cells/well) were plated in a 96 well tissue culture plate (Corning Life Sciences). BMMCs $\left(8.0 \times 10^{4}\right.$ cells/well) were plated in a plate treated with Corning® Cell-Tak Cell and Tissue Adhesive (Corning Incorporated-Life Sciences). Cells were sensitized or not with IgE anti-TNP for $16 \mathrm{~h}$ and then stimulated or not via FceRI, or $\mathrm{TG}$, or calcium ionophore for $5,15,30,45$, and $60 \mathrm{~min}$. $\beta$-hexosaminidase activity released was determined as previously described (Jamur et al., 2005). $\beta$-hexosaminidase activity was quantified in the supernatants and cell lysates by spectrophotometric analysis of hydrolysis of 4-Nitrophenyl N-acetyl- $\beta$-D-glucosaminide (Millipore Sigma). $\beta$-hexosaminidase release was calculated as the percentage of $\beta$-hexosaminidase activity measured in the supernatants relative to the total amount of $\beta$-hexosaminidase activity measured in the supernatant and cell lysates.

To asses lipid mediator release, RBL-2H3 MCs were plated $\left(1.0 \times 10^{5}\right.$ cells/well $)$ in a 24 well tissue culture plate (Corning Life Sciences) sensitized or not with IgE anti-TNP and FceRI activated or not for $30 \mathrm{~min}$. Release of PGD2 and LTC4 into culture supernatants was analyzed using EIA kits (Cayman Chemical, Ann Arbor, MI).

To measure newly synthesized cytokine release, RBL-2H3 MCs were plated $\left(1.0 \times 10^{5}\right.$ cells/well) in a 24 well tissue culture plate (Corning Life Sciences) sensitized or not with IgE anti-TNP and stimulated via FceRI or not for $1 \mathrm{~h}$. Culture supernatants were discarded and the cells were washed and incubated with fresh media for an additional $23 \mathrm{~h}$. The supernatants were collected and released cytokines were analyzed using the Proteome Profiler Rat Cytokine Array Kit, Panel A (R\&D Systems, Inc. Minneapolis, MN) according to the manufacturer's instructions.

\section{Calcium mobilization analysis by intracellular calcium concentration $\left(\left[\mathrm{Ca}^{2+}\right]_{i}\right)$} measurements 
To investigate the influence of RACK1 on stimulus dependent calcium mobilization in MCs, live cell calcium influx imaging was used. RBL-2H3 MCs $\left(2.5-4 \times 10^{4}\right.$ cells) were plated in $35 \mathrm{~mm}$ No. 1.0 glass-bottomed culture dishes (Mat Tek Corporation). Cells were then sensitized or not with IgE anti-TNP. After $16 \mathrm{~h}$, the media was discarded and the cells were washed twice with a standard extracellular solution (SES; $145 \mathrm{mM} \mathrm{NaCl}, 5 \mathrm{mM} \mathrm{KCl}, 1 \mathrm{mM}$ $\mathrm{MgCl}_{2}, 10 \mathrm{mM}$ glucose, $1 \mathrm{mM} \mathrm{CaCl}$, and $10 \mathrm{mM}$ HEPES; $\mathrm{pH} 7.4$ adjusted with $\mathrm{NaOH}$ ) with $0.1 \%$ BSA. Cells were incubated with the $\mathrm{Ca}^{2+}$ indicator Fura-2 acetoxymethyl ester $(2 \mu \mathrm{M}$; Calibiochem, San Diego, CA) diluted in SES for $30 \mathrm{~min}$ at $37^{\circ} \mathrm{C}$ in a $5 \% \mathrm{CO}_{2}$ incubator. Then, the cells were washed twice with SES with or without $\mathrm{CaCl}_{2}$ and analyzed, before and after stimulation. All the experiments were performed using an Olympus IX50 microscope (Olympus) coupled to a Polychrome V spectrofluorimeter (Till Photonics LLC, Pleasaton, CA). Fluorescence images were collected every 3 s until at least $600 \mathrm{~s}$ with a CoolSnap HQ camera (Photometrics, Tucson, AZ), and the data were analyzed with MetaFluor imaging software (Molecular Devices) and plotted using Origin software (OriginLab, Northampton, MA).

\section{Statistical analyses}

Results were analyzed using GraphPad Prism (GraphPad Software, Inc., La Jolla, CA). The results were expressed as mean \pm SD or SEM. In all shRNA experiments differences between the groups were assessed by one-way analysis of variance (ANOVA) with Bonferoni's post-hoc test. In other experiments, the significance of intergroup differences was evaluated by Student's $t$ test.

\section{ACKNOWLEDGEMENTS}

The authors thank Elizabete Rosa Milani and Dr. Roberta Rosales for assistance with the confocal microscopy; Maria Dolores Seabra Ferreira, Maria Teresa Picinoto Maglia and Jose Augusto Maulin for assistance with the electron microscopy; and Tânia A. Defina for assistance with the RT-PCR experiments, all from the Department of Cell and Molecular Biology and Pathogenic Biogents, FMRP-USP, Ribeirão Preto, SP, Brazil. We also thank Dr. Vania Luiza Deperon Bonato (Biochemistry and Immunology Department, FMRP-USP) for donation of mouse lung tissue. 


\section{AUTHOR CONTRIBUTIONS STATEMENT}

Conceptualization: E.G.F.F., I.S.A., C.O., and M.C.J.; Data Curation: E.G.F.F., H.L.O., L.C.B.; Formal Analysis: E.G.F.F., H.L.O., L.A.M.J., W.D.S., I.S.A., C.O., and M.C.J.; Funding acquisition: E.G.F.F., I.S.A., C.O., and M.C.J.; Investigation: E.G.F.F., I.S.A., C.O., and M.J.C.; Methodology: E.G.F.F., H.L.O., I.S.A., C.O., and M.C.J.; Project administration: E.G.F.F., I.S.A., and M.C.J.; Resources: E.G.F.F., I.S.A., C.O., and M.C.J.; Supervision: I.S.A., C.O., and M.C.J.; Validation: E.G.F.F., H.L.O., L.A.M.J.; Visualization: E.G.F.F., H.L.O., I.S.A., C.O., and M.C.J.; Writing - original draft preparation: E.G.F.F.; Writing review \& editing: E.G.F.F., H.L.O., L.M.J., I.S.A., C.O., and M.C.J.

\section{FUNDING}

This work was supported by research grants from Fundação de Amparo á Pesquisa do Estado de São Paulo (FAPESP, www.fapesp.br; E.G.F.F.: 2015/16673-0; E.G. F.F.: 2016/21988-2; M.C.J.: 2017/14645-4; C.O.: 2017/18618-1), Conselho Nacional de Desenvolvimento Científico e Tecnológico (CNPq, www.cnpq.br), Coordenação de Aperfeiçoamento de Pessoal de Nível Superior (Capes, www.capes.gov.br), and Fundação de Apoio ao Ensino, Pesquisa e Assistência do Hospital das Clínicas da Faculdade de Medicina de Ribeirão Preto da Universidade de São Paulo (FAEPA, www.faepa.br). The funders had no role in study design, data collection and analysis, decision to publish, or preparation of the manuscript.

\section{REFERENCES}

Adams, D.R., D. Ron, and P.A. Kiely. 2011. RACK1, A multifaceted scaffolding protein: Structure and function. Cell Commun Signal. 9:22.

Ambudkar, I.S., L.B. de Souza, and H.L. Ong. 2017. TRPC1, Orai1, and STIM1 in SOCE: Friends in tight spaces. Cell Calcium. 63:33-39.

Arock, M., A. Le Nours, O. Malbec, and M. Daëron. 2008. Ex vivo and in vitro primary mast cells. Methods Mol Biol. 415:241-254.

Aunis, D., and M.F. Bader. 1988. The cytoskeleton as a barrier to exocytosis in secretory cells. J Exp Biol. 139:253-266.

Baba, Y., and T. Kurosaki. 2008. [Regulation of store-operated calcium entry by STIM1]. Seikagaku. 80:1123-1128.

Baba, Y., K. Nishida, Y. Fujii, T. Hirano, M. Hikida, and T. Kurosaki. 2008. Essential function for the calcium sensor STIM1 in mast cell activation and anaphylactic responses. Nat Immunol. 9:81-88. 
Ballek, O., J. Valečka, M. Dobešová, A. Broučková, J. Manning, P. Řehulka, J. Stulík, and D. Filipp. 2016. TCR Triggering Induces the Formation of Lck-RACK1-Actinin-1 Multiprotein Network Affecting Lck Redistribution. Front Immunol. 7:449.

Bandyopadhyay, B.C., H.L. Ong, T.P. Lockwich, X. Liu, B.C. Paria, B.B. Singh, and I.S. Ambudkar. 2008. TRPC3 controls agonist-stimulated intracellular $\mathrm{Ca} 2+$ release by mediating the interaction between inositol 1,4,5-trisphosphate receptor and RACK1. $J$ Biol Chem. 283:32821-32830.

Barsumian, E.L., C. Isersky, M.G. Petrino, and R.P. Siraganian. 1981. IgE-induced histamine release from rat basophilic leukemia cell lines: isolation of releasing and nonreleasing clones. Eur J Immunol. 11:317-323.

Blank, U., I.K. Madera-Salcedo, L. Danelli, J. Claver, N. Tiwari, E. Sánchez-Miranda, G. Vázquez-Victorio, K.A. Ramírez-Valadez, M. Macias-Silva, and C. González-Espinosa. 2014. Vesicular trafficking and signaling for cytokine and chemokine secretion in mast cells. Front Immunol. 5:453.

Bradding, P., and G. Arthur. 2016. Mast cells in asthma--state of the art. Clin Exp Allergy. 46:194-263.

Bradford, M.M. 1976. A rapid and sensitive method for the quantitation of microgram quantities of protein utilizing the principle of protein-dye binding. Anal Biochem. 72:248-254.

Buensuceso, C.S., D. Woodside, J.L. Huff, G.E. Plopper, and T.E. O'Toole. 2001. The WD protein Rack1 mediates protein kinase $\mathrm{C}$ and integrin-dependent cell migration. J Cell Sci. 114:1691-1698.

Christensen, S.B., A. Andersen, J.C. Poulsen, and M. Treiman. 1993. Derivatives of thapsigargin as probes of its binding site on endoplasmic reticulum $\mathrm{Ca} 2+$ ATPase. Stereoselectivity and important functional groups. FEBS Lett. 335:345-348.

Cohen, R., K. Corwith, D. Holowka, and B. Baird. 2012. Spatiotemporal resolution of mast cell granule exocytosis reveals correlation with Ca2+ wave initiation. J Cell Sci. 125:2986-2994.

Corsini, E., V. Galbiati, A. Pinto, A. Davin, L. Polito, A. Guaita, and M. Racchi. 2015. Immunostimulatory effects of RACK1 pseudosubstrate in human leukocytes obtained from young and old donors. Oncotarget. 6:6524-6534.

Corsini, E., A. Pinto, V. Galbiati, B. Viviani, C.L. Galli, M. Marinovich, and M. Racchi. 2014. Corticosteroids modulate the expression of the PKC-anchoring protein RACK-1 and cytokine release in THP-1 cells. Pharmacol Res. 81:10-16.

Corsini, E., M. Racchi, L. Lucchi, E. Donetti, M. Bedoni, B. Viviani, C.L. Galli, and M. Marinovich. 2009. Skin immunosenescence: decreased receptor for activated C kinase-1 expression correlates with defective tumour necrosis factor-alpha production in epidermal cells. Br J Dermatol. 160:16-25.

da Silva, E.Z., M.C. Jamur, and C. Oliver. 2014. Mast cell function: a new vision of an old cell. J Histochem Cytochem. 62:698-738. 
Dar, O., and I. Pecht. 1992. Fc epsilon receptor mediated Ca2+ influx into mast cells is modulated by the concentration of cytosolic free Ca2+ ions. FEBS Lett. 310:123-128.

Deng, Z., T. Zink, H.Y. Chen, D. Walters, F.T. Liu, and G.Y. Liu. 2009. Impact of actin rearrangement and degranulation on the membrane structure of primary mast cells: a combined atomic force and laser scanning confocal microscopy investigation. Biophys J. 96:1629-1639.

Di Capite, J.L., G.J. Bates, and A.B. Parekh. 2011. Mast cell CRAC channel as a novel therapeutic target in allergy. Curr Opin Allergy Clin Immunol. 11:33-38.

Dráber, P., V. Sulimenko, and E. Dráberová. 2012. Cytoskeleton in mast cell signaling. Front Immunol. 3:130.

Duff, D., and A. Long. 2017. Roles for RACK1 in cancer cell migration and invasion. Cell Signal. 35:250-255.

Falcone, F.H., D. Wan, N. Barwary, and R. Sagi-Eisenberg. 2018. RBL cells as models for in vitro studies of mast cells and basophils. Immunol Rev. 282:47-57.

Freitas-Filho, E., L.A.M. Jaca, L.C. Baeza, C.M.d.A. Soares, C.L. Borges, C. Oliver, and M.C. Jamur. 2019. Proteomic analysis of lipid rafts from RBL-2H3 mast cells. Int. J. Mol. Sci. 20,3904.

Freitas-Filho, E.G., E.Z. da Silva, C.Z. Zanotto, C. Oliver, and M.C. Jamur. 2016. CrossLinking Mast Cell Specific Gangliosides Stimulates the Release of Newly Formed Lipid Mediators and Newly Synthesized Cytokines. Mediators Inflamm. 2016:9160540.

Frigeri, L., and J.R. Apgar. 1999. The role of actin microfilaments in the down-regulation of the degranulation response in RBL-2H3 mast cells. J Immunol. 162:2243-2250.

Föger, N., A. Jenckel, Z. Orinska, K.H. Lee, A.C. Chan, and S. Bulfone-Paus. 2011. Differential regulation of mast cell degranulation versus cytokine secretion by the actin regulatory proteins Coronin1a and Coronin1b. J Exp Med. 208:1777-1787.

Galli, S.J. 2016. The Mast Cell-IgE Paradox: From Homeostasis to Anaphylaxis. Am J Pathol. 186:212-224.

Haberman, Y., L.T. Alon, E. Eliyahu, and R. Shalgi. 2011. Receptor for activated C kinase (RACK) and protein kinase C (PKC) in egg activation. Theriogenology. 75:80-89.

Holowka, D., M. Wilkes, C. Stefan, and B. Baird. 2016. Roles for Ca2+ mobilization and its regulation in mast cell functions: recent progress. Biochem Soc Trans. 44:505-509.

Hwang, S., S.W. Son, S.C. Kim, Y.J. Kim, H. Jeong, and D. Lee. 2008. A protein interaction network associated with asthma. J Theor Biol. 252:722-731.

Jamur, M.C., A.C. Grodzki, E.H. Berenstein, M.M. Hamawy, R.P. Siraganian, and C. Oliver. 2005. Identification and characterization of undifferentiated mast cells in mouse bone marrow. Blood. 105:4282-4289.

Jamur, M.C., and C. Oliver. 1996. Binding of antibody to the gamma subunit of FCepsilonRI 
in rat basophilic leukemia cells results in morphological changes without inducing histamine release. Cell Tissue Res. 284:153-159.

Jia, D., F. Duan, P. Peng, L. Sun, X. Liu, L. Wang, W. Wu, Y. Ruan, and J. Gu. 2013. Upregulation of RACK1 by TGF- $\beta 1$ promotes hepatic fibrosis in mice. PLoS One. 8:e60115.

Karasuyama, H., K. Miyake, S. Yoshikawa, and Y. Yamanishi. 2018. Multifaceted roles of basophils in health and disease. J Allergy Clin Immunol. 142:370-380.

Kershner, L., and K. Welshhans. 2017. RACK1 is necessary for the formation of point contacts and regulates axon growth. Dev Neurobiol. 77:1038-1056.

Klímová, Z., V. Bráborec, M. Maninová, J. Čáslavský, M.J. Weber, and T. Vomastek. 2016. Symmetry breaking in spreading RAT2 fibroblasts requires the MAPK/ERK pathway scaffold RACK1 that integrates FAK, p190A-RhoGAP and ERK2 signaling. Biochim Biophys Acta. 1863:2189-2200.

Madera-Salcedo, I.K., L. Danelli, N. Tiwari, B. Dema, E. Pacreau, S. Vibhushan, J. Birnbaum, C. Agabriel, V. Liabeuf, C. Klingebiel, G. Menasche, M. Macias-Silva, M. Benhamou, N. Charles, C. González-Espinosa, J. Vitte, and U. Blank. 2018. Tomosyn functions as a PKC $\delta$-regulated fusion clamp in mast cell degranulation. Sci Signal. 11.

Mukai, K., M. Tsai, H. Saito, and S.J. Galli. 2018. Mast cells as sources of cytokines, chemokines, and growth factors. Immunol Rev. 282:121-150.

Müsch, A., D. Cohen, and E. Rodriguez-Boulan. 1997. Myosin II is involved in the production of constitutive transport vesicles from the TGN. J Cell Biol. 138:291-306.

Neasta, J., A. Fiorenza, D.Y. He, K. Phamluong, P.A. Kiely, and D. Ron. 2016. Activation of the cAMP Pathway Induces RACK1-Dependent Binding of $\beta$-Actin to BDNF Promoter. PLoS One. 11:e0160948.

Negoro, T., S. Shimizu, M. Narushima, A.H. Banham, H. Wakabayashi, R. Takayanagi, T. Hagiwara, G. Roncador, T. Osabe, T. Yanai, M. Kin, K. Ikeda, A. Endo, H. Akiyama, and Y. Nakano. 2014. Elevated receptor for activated $\mathrm{C}$ kinase 1 expression is involved in intracellular $\mathrm{Ca} 2+$ influx and potentially associated with compromised regulatory $\mathrm{T}$ cell function in patients with asthma. Clin Exp Allergy. 44:1154-1169.

Nishida, K., S. Yamasaki, Y. Ito, K. Kabu, K. Hattori, T. Tezuka, H. Nishizumi, D. Kitamura, R. Goitsuka, R.S. Geha, T. Yamamoto, T. Yagi, and T. Hirano. 2005. Fc\{epsilon\}RImediated mast cell degranulation requires calcium-independent microtubule-dependent translocation of granules to the plasma membrane. J Cell Biol. 170:115-126.

O'Donovan, H.C., P.A. Kiely, and R. O'Connor. 2007. Effects of RACK1 on cell migration and IGF-I signalling in cardiomyoctes are not dependent on an association with the IGF-IR. Cell Signal. 19:2588-2595.

Patterson, R.L., D.B. van Rossum, R.K. Barrow, and S.H. Snyder. 2004. RACK1 binds to inositol 1,4,5-trisphosphate receptors and mediates Ca2+ release. Proc Natl Acad Sci U S A. 101:2328-2332. 
Pejler, G., M. Abrink, M. Ringvall, and S. Wernersson. 2007. Mast cell proteases. $A d v$ Immunol. 95:167-255.

Perrin, B.J., and J.M. Ervasti. 2010. The actin gene family: function follows isoform. Cytoskeleton (Hoboken). 67:630-634.

Pressman, B.C. 1976. Biological applications of ionophores. Annu Rev Biochem. 45:501-530.

Pu, Y., Y. Liu, S. Liao, S. Miao, L. Zhou, and L. Wan. 2018. Azithromycin ameliorates OVAinduced airway remodeling in Balb/c mice via suppression of epithelial-tomesenchymal transition. Int Immunopharmacol. 58:87-93.

Ron, D., D.R. Adams, G.S. Baillie, A. Long, R. O'Connor, and P.A. Kiely. 2013. RACK1 to the future--a historical perspective. Cell Commun Signal. 11:53.

Ron, D., C.H. Chen, J. Caldwell, L. Jamieson, E. Orr, and D. Mochly-Rosen. 1994. Cloning of an intracellular receptor for protein kinase $\mathrm{C}$ : a homolog of the beta subunit of $\mathrm{G}$ proteins. Proc Natl Acad Sci U S A. 91:839-843.

Schindelin, J., I. Arganda-Carreras, E. Frise, V. Kaynig, M. Longair, T. Pietzsch, S. Preibisch, C. Rueden, S. Saalfeld, B. Schmid, J.Y. Tinevez, D.J. White, V. Hartenstein, K. Eliceiri, P. Tomancak, and A. Cardona. 2012. Fiji: an open-source platform for biological-image analysis. Nat Methods. 9:676-682.

Schober, J.M., J.M. Cain, Y.A. Komarova, and G.G. Borisy. 2009. Migration and actin protrusion in melanoma cells are regulated by EB1 protein. Cancer Lett. 284:30-36.

Serrels, B., E. Sandilands, and M.C. Frame. 2011. Signaling of the direction-sensing FAK/RACK1/PDE4D5 complex to the small GTPase Rap1. Small GTPases. 2:54-61.

Shelby, S.A., S.L. Veatch, D.A. Holowka, and B.A. Baird. 2016. Functional nanoscale coupling of Lyn kinase with IgE-FceRI is restricted by the actin cytoskeleton in early antigen-stimulated signaling. Mol Biol Cell. 27:3645-3658.

Siraganian, R.P., R.O. de Castro, E.A. Barbu, and J. Zhang. 2010. Mast cell signaling: the role of protein tyrosine kinase Syk, its activation and screening methods for new pathway participants. FEBS Lett. 584:4933-4940.

Spector, I., N.R. Shochet, Y. Kashman, and A. Groweiss. 1983. Latrunculins: novel marine toxins that disrupt microfilament organization in cultured cells. Science. 219:493-495.

Vig, M., W.I. DeHaven, G.S. Bird, J.M. Billingsley, H. Wang, P.E. Rao, A.B. Hutchings, M.H. Jouvin, J.W. Putney, and J.P. Kinet. 2008. Defective mast cell effector functions in mice lacking the CRACM1 pore subunit of store-operated calcium release-activated calcium channels. Nat Immunol. 9:89-96.

Wang, F., T. Osawa, R. Tsuchida, Y. Yuasa, and M. Shibuya. 2011. Downregulation of receptor for activated C-kinase 1 (RACK1) suppresses tumor growth by inhibiting tumor cell proliferation and tumor-associated angiogenesis. Cancer Sci. 102:2007-2013.

Wernersson, S., and G. Pejler. 2014. Mast cell secretory granules: armed for battle. Nat Rev Immunol. 14:478-494. 
1032

1033

1034

1035

1036

1037

1038

1039

1040

1041
Wilson, J.D., S.A. Shelby, D. Holowka, and B. Baird. 2016. Rab11 Regulates the Mast Cell Exocytic Response. Traffic. 17:1027-1041.

Wollman, R., and T. Meyer. 2012. Coordinated oscillations in cortical actin and Ca2+ correlate with cycles of vesicle secretion. Nat Cell Biol. 14:1261-1269.

Woodard, G.E., J.J. López, I. Jardín, G.M. Salido, and J.A. Rosado. 2010. TRPC3 regulates agonist-stimulated $\mathrm{Ca} 2+$ mobilization by mediating the interaction between type I inositol 1,4,5-trisphosphate receptor, RACK1, and Orai1. J Biol Chem. 285:8045-8053.

Yao, F., L.Y. Long, Y.Z. Deng, Y.Y. Feng, G.Y. Ying, W.D. Bao, G. Li, D.X. Guan, Y.Q. Zhu, J.J. Li, and D. Xie. 2014. RACK1 modulates NF- $\kappa B$ activation by interfering with the interaction between TRAF2 and the IKK complex. Cell Res. 24:359-371. 
1042

1043

\section{SUPPLEMENTAL FIGURES}
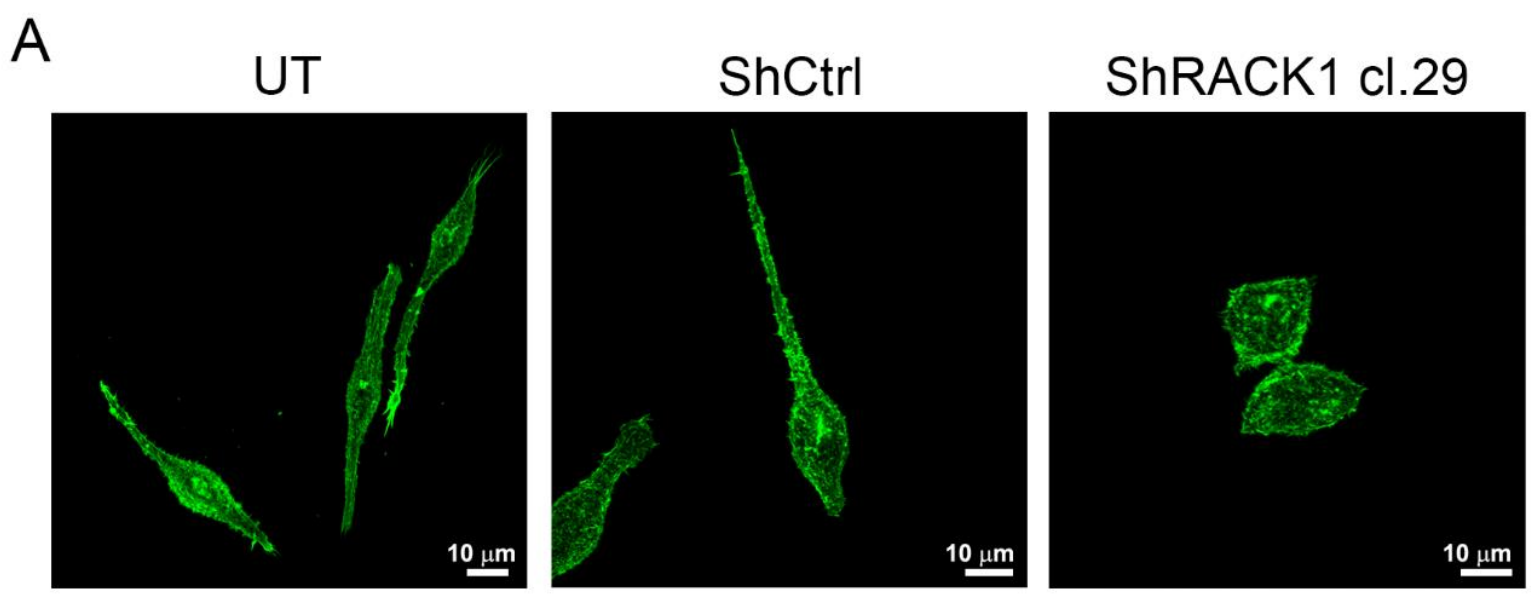

B

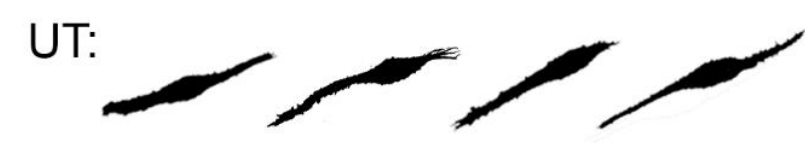

ShCtrl:

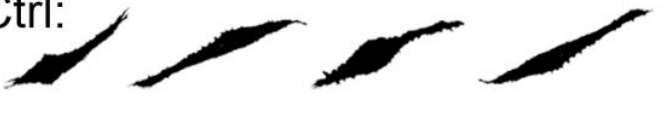

ShRACK1 cl.29:

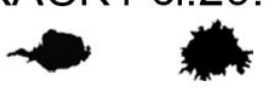

C

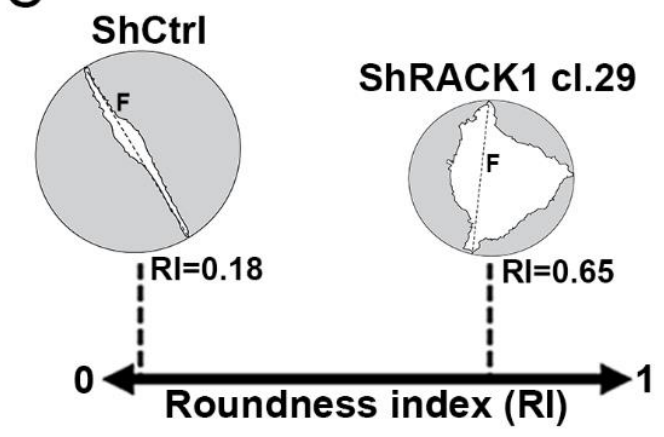

Supplemental Figure 1. Roundness index measurements confirm that RACK1 regulates cell shape in RBLMCs (ShRACK1 cl.29) were stained with phalloidin conjugated with Alexa 488 to visualize the cell morphology. (A) Representative confocal microscopy images of stained cells are shown. (B) The scanning confocal microscopy images were used to create the black-and-white representation, accentuating the shape of individual cells and used for further analysis. (C) Determination of roundness index (RI) and cell area were performed using the ImageJ. Schematic representation of cells with indicated Feret's diameter (F; dashed line), area of circle (gray) calculated based on Feret's diameter superimposed on the cell area (white). These parameters were used for determination of 
A

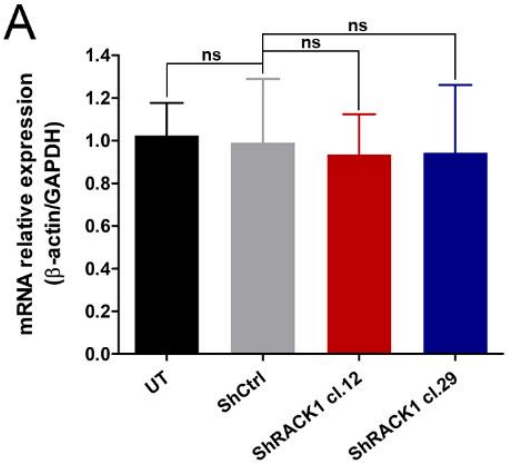

B

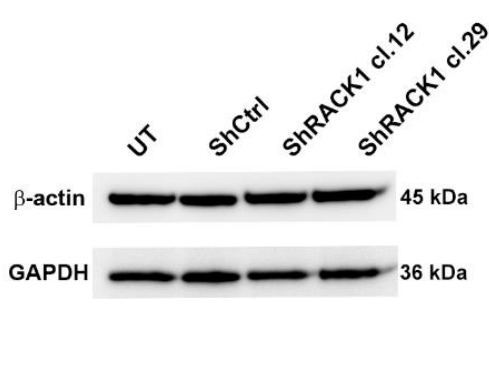

C

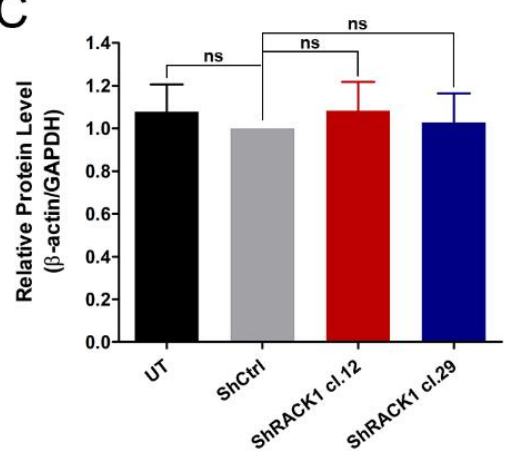

Supplemental Figure 2. shRNA mediated depletion of RACK1 does not affect $\beta$-actin expression in RBL2H3 mast cells. RBL-2H3 MCs were transduced, or not (UT), with lentiviral particles expressing nontargeting control shRNA (ShCtrl) or with particles expressing shRNAs against RACK1 (ShRACK1 cl.12 and ShRACK1 cl.29). (A) $\beta$-actin mRNA expression was determined by quantitative RT-PCR using GAPDH mRNA expression as an internal control. (B) Total cell lysates were immunoblotted with antibodies against $\beta$-actin and GAPDH and a representative Western blot images are shown. (C) Mean optical density was determined and relative protein levels of $\beta$-actin/GAPDH were calculated. The protein ratio was set at 1 for ShCtrl. Data are expressed as the mean \pm SD of three independent experiments. ${ }^{*} p<0.01$ vs. ShCtrl. ns: not significant. 
A

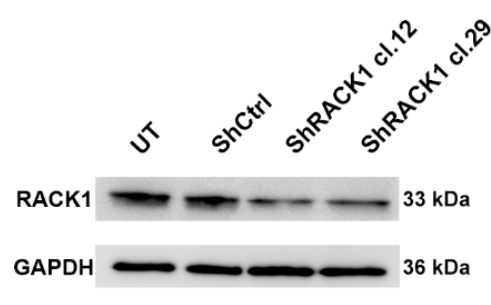

B

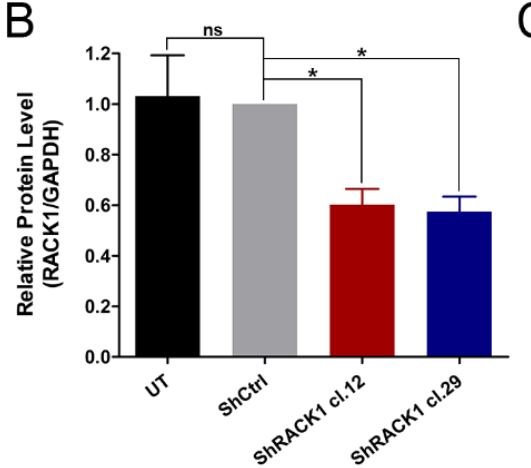

C

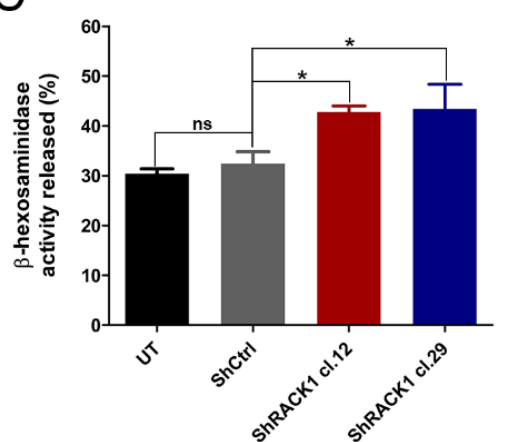

Supplemental Figure 3. RACK1 knockdown results in an increase in antigen-induced degranulation by bone marrow derived mast cells (BMMCs). To knock down RACK1, BMMCs were transduced or not (UT) with lentiviral particles expressing nontargeting control shRNA (ShCtrl) or with particles expressing shRNAs against RACK1 (ShRACK1 cl.12 and ShRACK1 cl.29). (A) Total cell lysates were immunoblotted with antibodies against RACK1 and GAPDH and representative Western blot images are shown. (B) Mean optical density was determined and relative protein levels of RACK1/GAPDH were calculated. (C) For antigen stimulation via Fc\&RI, cells were sensitized or not with IgE anti-TNP and stimulated via FceRI with $50 \mathrm{ng} / \mathrm{mL} \mathrm{DNP} \mathrm{D}_{54}-\mathrm{HSA}$ for $60 \mathrm{~min}$. The released $\beta$-hexosaminidase activity was determined. Data are expressed as the mean \pm SEM of three 
A
B

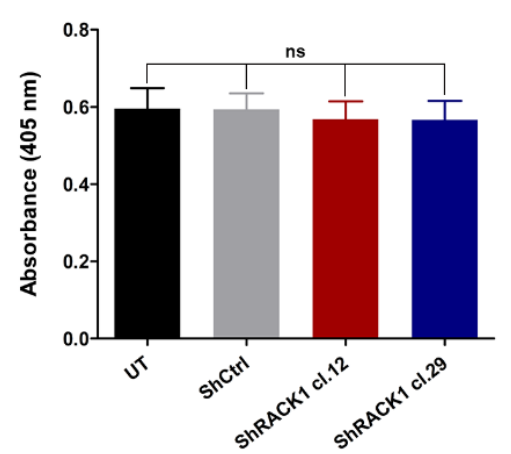

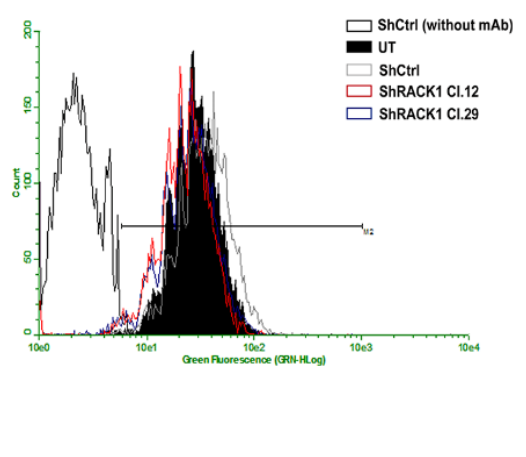

C

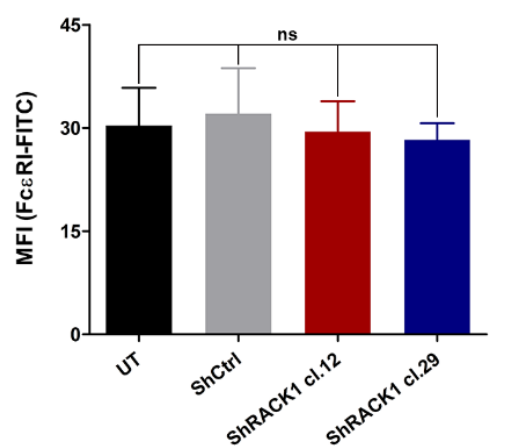

Supplemental Figure 4. ShRNA mediated depletion of RACK1 does not interfere with total $\beta$ hexosaminidase activity or surface expression of FceRI. (A) The total $\beta$-hexosaminidase activity was determined in untransduced RBL-2H3 MCs (UT), cells transduced with control shRNA (ShCtrl), and cells transduced with RACK1 shRNAs (ShRACK1 cl.12 and ShRACK1 cl.29). Non-permeabilized cells were immunolabeled with anti-FceRI $\alpha$ subunit (mAb BC4) conjugated to FITC. (B) Representative fluorescence histogram from FACS analysis. (C) Median fluorescence intensity (MFI) of FceRI surface expression as determined by FACS analysis. Data are expressed as the mean \pm SD of three independent experiments. ns: not significant. 
A

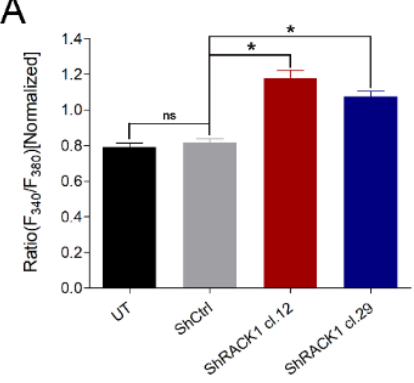

C

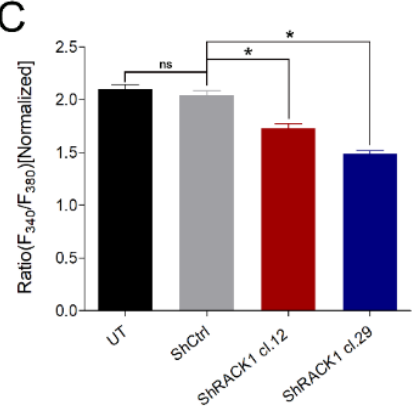

E

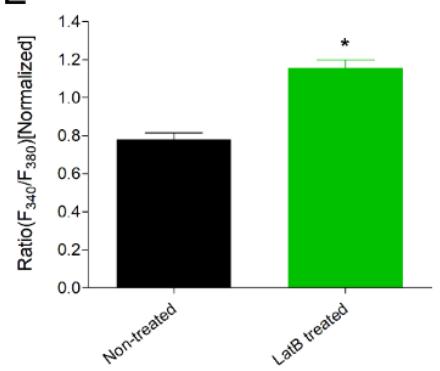

G

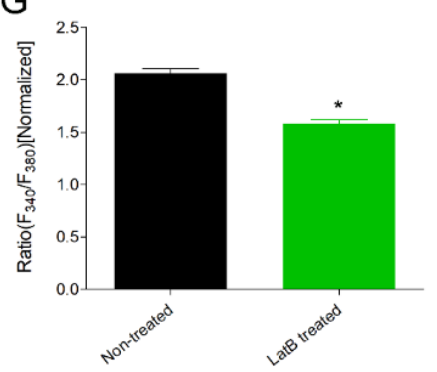

B

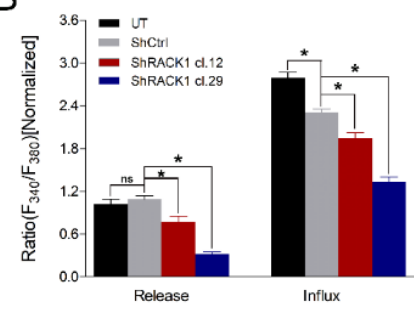

D

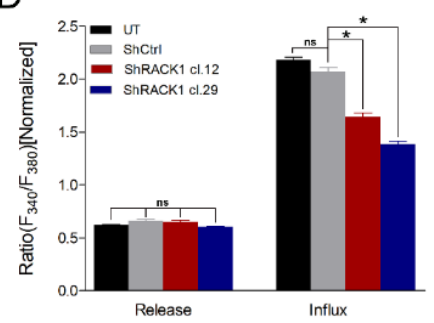

F

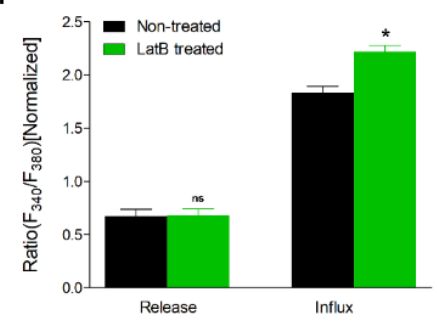

$\mathrm{H}$

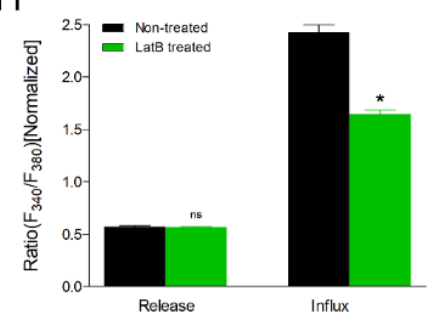

Supplemental Figure 5. Statistical analysis of calcium mobilization experiments. Cells were sensitized or not with IgE anti-TNP, loaded with Fura-2, and stimulated (A-B; E-F) via FceRI with $50 \mathrm{ng} / \mathrm{mL}$ DNP 54 -HSA or (CD; G-H) with $1 \mu \mathrm{M} \mathrm{TG}$. $\left[\mathrm{Ca}^{2+}\right]_{i}$ was determined by averaging the ratio of fluorescence intensity when Fura-2 was excited at 340 and $360 \mathrm{~nm}$. (A) Average fluorescence intensity (Fig. 11A) were obtained by subtracting the resting fluorescence intensity from the peak at $546 \mathrm{~s}$. (B) Average data from both $\mathrm{Ca}^{2+}$ release from ER stores and $\mathrm{Ca}^{2+}$ influx (Fig. 11B) were obtained by subtracting the resting fluorescence from the peak. (C) Average data were obtained from subtracting the resting fluorescence from the peak (Fig. 11C). (D) Average data from both $\mathrm{Ca}^{2+}$ release and $\mathrm{Ca}^{2+}$ influx (Fig. 11D) were obtained by subtracting the resting fluorescence from the peak. (E) Average fluorescence intensity (Fig. 12A) were obtained by subtracting the resting fluorescence intensity from the peak at 546 s. (F) Average data from both $\mathrm{Ca}^{2+}$ release from ER stores and $\mathrm{Ca}^{2+}$ influx (Fig. 12B) were obtained by subtracting the resting fluorescence from the peak. (G) Average data were obtained from subtracting the resting fluorescence from the peak (Fig. 13A). (H) Average data from both $\mathrm{Ca}^{2+}$ release and $\mathrm{Ca}^{2+}$ influx (Fig. 13B) were obtained by subtracting the resting fluorescence from the peak. Data are expressed as the mean \pm SEM of a minimum of three independent experiments. ${ }^{*} \mathrm{p}<0.05$ vs. ShCtrl or non-treated cells. ns: not significant. UT: untransduced RBL-2H3 MCs; ShCtrl: cells transduced with control shRNA; ShRACK1 cl.12: cells transduced with RACK1 cl.12 shRNA; ShRACK1 cl.29: cells transduced with RACK1 cl.29 shRNA. Non-treated: ShCtrl cells non-treated with latrunculin B. LatB treated: pretreated ShCtrl cells with $0.5 \mu \mathrm{M}$ latrunculin B. 
FINAL CONSIDERATIONS 


\section{FINAL CONSIDERATIONS}

The first research article (Chapter I) evaluated whether cross-linking GD1b derived gangliosides on the surface of RBL-2H3 MCs would have any impact on the release of MC mediators. It had been previously observed that cross-linking the MC-specific GD1b derived gangliosides with mAb AA4 resulted in a partial MC activation without inducing degranulation (Basciano et al., 1986; Oliver et al., 1992; Swaim et al., 1994). In this first article, the results show that cross-liking the gangliosides stimulated the release of both immediate and delayed release of PGD2 and PGE2, which was dependent on partial activation of the arachidonic acid pathway without the release of leukotrienes. Cross-linking the gangliosides also resulted in cytokines release due to phosphorylation of MAP Kinases and activation of the transcription factors NFKB and NFAT.

The finding that $\mathrm{MC}$ derived lipid mediators and cytokines can be released, even without degranulation, contributes to the understanding of the diverse responses triggered by MCs. Furthermore, many MC mediators can act in an autocrine fashion in order to amplify or suppress FceRI dependent MC activation. Indeed, it is accepted that MC mediator release is not an 'allor-nothing' process (Krystel-Whittemore et al., 2015), and that MCs receive and integrate a wide array of chemical signals from their environment, that stimulate mobilization of their effector properties (Gilfillan and Beaven, 2011). This is the first report of MC mediator release induced by cross-linking MC specific gangliosides. Although mAb AA4 is specific for rodent MCs, these results open the possibility that antibodies against other gangliosides, such as those produced in autoimmune diseases like Guillain-Barré syndrome, can trigger MC activation. Therefore, the present study (Freitas-Filho et al., 2016) helps to explain the extremely broad spectrum of mechanisms by which MCs might act in suppressing, amplifying, and modulating immune responses.

The second research article (Chapter II) resulted from the lack of a proteomic profile of MCs. Because of our previous study on the function of gangliosides, a lipid raft component, in MC mediator release, efforts were focused on obtaining a proteomic profile of MC lipid rafts. There were several challenges facing these efforts, such as the generally low abundance and difficulty in trypsin digestion of certain raft proteins, as well as the difficulties in handing postisolation the lipid raft enriched fractions. In order to overcome this, two methods were used to treat the samples, post-isolation. A total of 949 lipid raft associated proteins were identified by both methods and the majority of them had previously been highly cited and experimentally validated in other lipid raft proteomes. Despite the fact that modern mass spectrometers are 
sensitive and can easily identify hundreds or thousands of proteins, there is no current technique for quickly verifying or validating the mass spectrometry data. Therefore, bioinformatic tools were used to functionally analyze the proteome of raft-associated proteins and to determine the relationship between individual proteins and to cluster them. This approach has further elucidated the role of MC raft microdomains and their mutual regulation of/by membrane proteins. Therefore, the proteomic analysis of MC lipid rafts (Freitas-Filho et al., 2019) provides an important tool for further investigation of the molecular mechanisms and novel regulatory proteins related to MCs.

The proteomic profile showed, for the first time, the presence of the scaffold protein RACK1 in MCs. The third research article (Chapter III) highlighted RACK1 as a novel modulator of MC degranulation due its critical function as a signal hub for actin cytoskeleton dynamics and calcium mobilization in MCs. RACK1 plays a central role in maintaining cortical F-actin, thus regulating degranulation. RACK1 was also involved in the FceRI activated release of newly synthesized cytokines especially those are NFKB-dependent. Additionally, RACK1 depletion increased antigen-stimulated $\mathrm{Ca}^{2+}$-mobilization, but impaired antigen-stimulated $\mathrm{Ca}^{2+}$ ER-store depletion and thapsigargin-induced $\mathrm{Ca}^{2+}$-entry. Following MC FceRI activation there was an increase in interaction of RACK1 with $\beta$-actin and Orai1 $\mathrm{Ca}^{2+}$-channel. However, the precise molecular mechanisms behind this regulation is not totally understood and deserves further investigation in MCs. However, this is the first study (Freitas-Filho et al., 2019; manuscript in preparation) that demonstrates the complex role of RACK1 in regulated secretion by integrating multiple cellular events. Therefore, our results contribute a better understanding the molecular mechanisms involved in SG release. 
CONCLUSIONS 


\section{CONCLUSIONS}

\section{CHAPTER I}

The MC specific gangliosides derived from GD1b, a lipid raft components, modulate the release of newly formed lipid mediators (PGs) and newly synthesized mediators (cytokines) by partial activation of the arachidonic acid pathway and activation of MAP Kinases and transcription factors.

\section{CHAPTER II}

A comprehensive study of the MC lipid raft proteome shows that the two methods used increase the proteome coverage and improve the identification of lipid raft proteins as well as associated proteins. This study highlights that raft microdomains and their proteins are involved in various aspects of $\mathrm{MC}$ function, especially those related to regulated secretion, organization and stabilization of macromolecules complexes, and signal transduction pathways.

\section{CHAPTER III}

The scaffold protein RACK1 is critical for mediator release in MCs and regulates actin cytoskeleton organization and calcium signaling. 
REFERENCES 


\section{REFERENCES}

Adams, D.R., D. Ron, and P.A. Kiely. 2011. RACK1, A multifaceted scaffolding protein: Structure and function. Cell Commun Signal. 9:22.

Ambudkar, I.S., L.B. de Souza, and H.L. Ong. 2017. TRPC1, Orai1, and STIM1 in SOCE: Friends in tight spaces. Cell Calcium. 63:33-39.

Anand, P., B. Singh, A.S. Jaggi, and N. Singh. 2012. Mast cells: an expanding pathophysiological role from allergy to other disorders. Naunyn Schmiedebergs Arch Pharmacol. 385:657-670.

Andersson, C.K., M. Mori, L. Bjermer, C.G. Löfdahl, and J.S. Erjefält. 2009. Novel sitespecific mast cell subpopulations in the human lung. Thorax. 64:297-305.

Baba, Y., and T. Kurosaki. 2008. [Regulation of store-operated calcium entry by STIM1]. Seikagaku. 80:1123-1128.

Baba, Y., K. Nishida, Y. Fujii, T. Hirano, M. Hikida, and T. Kurosaki. 2008. Essential function for the calcium sensor STIM1 in mast cell activation and anaphylactic responses. Nat Immunol. 9:81-88.

Ballek, O., J. Valečka, M. Dobešová, A. Broučková, J. Manning, P. Řehulka, J. Stulík, and D. Filipp. 2016. TCR Triggering Induces the Formation of Lck-RACK1-Actinin-1 Multiprotein Network Affecting Lck Redistribution. Front Immunol. 7:449.

Barbosa-Lorenzi, V.C., N.T. Cecilio, P.A. de Almeida Buranello, M.C. Pranchevicius, M.H. Goldman, G. Pereira-da-Silva, M.C. Roque-Barreira, M.C. Jamur, and C. Oliver. 2016. Recombinant ArtinM activates mast cells. BMC Immunol. 17:22.

Basciano, L.K., E.H. Berenstein, L. Kmak, and R.P. Siraganian. 1986. Monoclonal antibodies that inhibit IgE binding. J Biol Chem. 261:11823-11831.

Benhamou, M., V. Stephan, K.C. Robbins, and R.P. Siraganian. 1992. High-affinity IgE receptor-mediated stimulation of rat basophilic leukemia (RBL-2H3) cells induces early and late protein-tyrosine phosphorylations. J Biol Chem. 267:7310-7314.

Bi, J., Q. Zhao, L. Zhu, X. Li, G. Yang, J. Liu, and G. Yin. 2018. RACK1 is indispensable for porcine reproductive and respiratory syndrome virus replication and NF- $\kappa \mathrm{B}$ activation in Marc-145 cells. Sci Rep. 8:2985.

Bieberich, E. 2018. Sphingolipids and lipid rafts: Novel concepts and methods of analysis. Chem Phys Lipids. 216:114-131.

Bini, L., S. Pacini, S. Liberatori, S. Valensin, M. Pellegrini, R. Raggiaschi, V. Pallini, and C.T. Baldari. 2003. Extensive temporally regulated reorganization of the lipid raft proteome following T-cell antigen receptor triggering. Biochem J. 369:301-309.

Blank, U., I.K. Madera-Salcedo, L. Danelli, J. Claver, N. Tiwari, E. Sánchez-Miranda, G. Vázquez-Victorio, K.A. Ramírez-Valadez, M. Macias-Silva, and C. González-Espinosa. 2014. Vesicular trafficking and signaling for cytokine and chemokine secretion in mast cells. Front Immunol. 5:453. 
Boyden, S.E., D.D. Metcalfe, and H.D. Komarow. 2016. Vibratory Urticaria and ADGRE2. N Engl J Med. 375:95.

Bradding, P. 2009. Human lung mast cell heterogeneity. Thorax. 64:278-280.

Bradding, P., and G. Arthur. 2016. Mast cells in asthma--state of the art. Clin Exp Allergy. 46:194-263.

Calloway, N., M. Vig, J.P. Kinet, D. Holowka, and B. Baird. 2009. Molecular clustering of STIM1 with Orai1/CRACM1 at the plasma membrane depends dynamically on depletion of Ca2+ stores and on electrostatic interactions. Mol Biol Cell. 20:389-399.

Calura, E., S. Cagnin, A. Raffaello, P. Laveder, G. Lanfranchi, and C. Romualdi. 2008. Metaanalysis of expression signatures of muscle atrophy: gene interaction networks in early and late stages. BMC Genomics. 9:630.

Cambier, J.C. 1995. Antigen and Fc receptor signaling. The awesome power of the immunoreceptor tyrosine-based activation motif (ITAM). J Immunol. 155:3281-3285.

Cantù, L., E. Del Favero, S. Sonnino, and A. Prinetti. 2011. Gangliosides and the multiscale modulation of membrane structure. Chem Phys Lipids. 164:796-810.

Caslin, H.L., K.N. Kiwanuka, T.T. Haque, M.T. Taruselli, H.P. MacKnight, A. Paranjape, and J.J. Ryan. 2018. Controlling Mast Cell Activation and Homeostasis: Work Influenced by Bill Paul That Continues Today. Front Immunol. 9:868.

Cheng, K.T., H.L. Ong, X. Liu, and I.S. Ambudkar. 2013. Contribution and regulation of TRPC channels in store-operated Ca2+ entry. Curr Top Membr. 71:149-179.

Cohen, R., K. Corwith, D. Holowka, and B. Baird. 2012. Spatiotemporal resolution of mast cell granule exocytosis reveals correlation with Ca2+ wave initiation. J Cell Sci. 125:29862994.

Cohen, R., A. Torres, H.T. Ma, D. Holowka, and B. Baird. 2009. Ca2+ waves initiate antigenstimulated Ca2+ responses in mast cells. J Immunol. 183:6478-6488.

Colin-York, H., D. Li, K. Korobchevskaya, V.T. Chang, E. Betzig, C. Eggeling, and M. Fritzsche. 2019. Cytoskeletal actin patterns shape mast cell activation. Commun Biol. 2:93.

Columbo, M., E.M. Horowitz, L.M. Botana, D.W. MacGlashan, B.S. Bochner, S. Gillis, K.M. Zsebo, S.J. Galli, and L.M. Lichtenstein. 1992. The human recombinant c-kit receptor ligand, rhSCF, induces mediator release from human cutaneous mast cells and enhances IgEdependent mediator release from both skin mast cells and peripheral blood basophils. $J$ Immunol. 149:599-608.

Corsini, E., F. Battaini, L. Lucchi, M. Marinovich, M. Racchi, S. Govoni, and C.L. Galli. 1999. A defective protein kinase $\mathrm{C}$ anchoring system underlying age-associated impairment in TNF-alpha production in rat macrophages. J Immunol. 163:3468-3473.

Corsini, E., V. Galbiati, A. Pinto, A. Davin, L. Polito, A. Guaita, and M. Racchi. 2015. Immunostimulatory effects of RACK1 pseudosubstrate in human leukocytes obtained from young and old donors. Oncotarget. 6:6524-6534. 
Corsini, E., A. Pinto, V. Galbiati, B. Viviani, C.L. Galli, M. Marinovich, and M. Racchi. 2014. Corticosteroids modulate the expression of the PKC-anchoring protein RACK-1 and cytokine release in THP-1 cells. Pharmacol Res. 81:10-16.

Corsini, E., M. Racchi, L. Lucchi, E. Donetti, M. Bedoni, B. Viviani, C.L. Galli, and M. Marinovich. 2009. Skin immunosenescence: decreased receptor for activated C kinase-1 expression correlates with defective tumour necrosis factor-alpha production in epidermal cells. Br J Dermatol. 160:16-25.

Corsini, E., M. Racchi, E. Sinforiani, L. Lucchi, B. Viviani, G.E. Rovati, S. Govoni, C.L. Galli, and M. Marinovich. 2005. Age-related decline in RACK-1 expression in human leukocytes is correlated to plasma levels of dehydroepiandrosterone. J Leukoc Biol. 77:247256.

Cox, E.A., D. Bennin, A.T. Doan, T. O'Toole, and A. Huttenlocher. 2003. RACK1 regulates integrin-mediated adhesion, protrusion, and chemotactic cell migration via its Src-binding site. Mol Biol Cell. 14:658-669.

da Silva, E.Z., M.C. Jamur, and C. Oliver. 2014. Mast cell function: a new vision of an old cell. J Histochem Cytochem. 62:698-738.

Dar, O., and I. Pecht. 1992. Fc epsilon receptor mediated Ca2+ influx into mast cells is modulated by the concentration of cytosolic free Ca2+ ions. FEBS Lett. 310:123-128.

Dave, J.M., H. Kang, C.A. Abbey, S.A. Maxwell, and K.J. Bayless. 2013. Proteomic profiling of endothelial invasion revealed receptor for activated C kinase 1 (RACK1) complexed with vimentin to regulate focal adhesion kinase (FAK). J Biol Chem. 288:30720-30733.

de Castro, R.O., J. Zhang, M.C. Jamur, C. Oliver, and R.P. Siraganian. 2010. Tyrosines in the carboxyl terminus regulate Syk kinase activity and function. J Biol Chem. 285:26674-26684.

de Souza, D.A., V.D. Toso, M.R. Campos, V.S. Lara, C. Oliver, and M.C. Jamur. 2012. Expression of mast cell proteases correlates with mast cell maturation and angiogenesis during tumor progression. PLoS One. 7:e40790.

Deng, Z., T. Zink, H.Y. Chen, D. Walters, F.T. Liu, and G.Y. Liu. 2009. Impact of actin rearrangement and degranulation on the membrane structure of primary mast cells: a combined atomic force and laser scanning confocal microscopy investigation. Biophys $J$. 96:1629-1639.

Dhungana, S., B.A. Merrick, K.B. Tomer, and M.B. Fessler. 2009. Quantitative proteomics analysis of macrophage rafts reveals compartmentalized activation of the proteasome and of proteasome-mediated ERK activation in response to lipopolysaccharide. Mol Cell Proteomics. 8:201-213.

Di Capite, J.L., G.J. Bates, and A.B. Parekh. 2011. Mast cell CRAC channel as a novel therapeutic target in allergy. Curr Opin Allergy Clin Immunol. 11:33-38.

Diaz, B.L., H. Fujishima, A. Sapirstein, J.V. Bonventre, and J.P. Arm. 2002. Participation of cytosolic phospholipase A2 in eicosanoid generation by mouse bone marrow-derived mast cells. Adv Exp Med Biol. 507:41-46. 
Diaz-Rohrer, B.B., K.R. Levental, K. Simons, and I. Levental. 2014. Membrane raft association is a determinant of plasma membrane localization. Proc Natl Acad Sci U S A. 111:8500-8505.

Draber, P., I. Halova, F. Levi-Schaffer, and L. Draberova. 2011. Transmembrane adaptor proteins in the high-affinity IgE receptor signaling. Front Immunol. 2:95.

Dráber, P., and L. Dráberová. 2002. Lipid rafts in mast cell signaling. Mol Immunol. 38:12471252.

Dráber, P., V. Sulimenko, and E. Dráberová. 2012. Cytoskeleton in mast cell signaling. Front Immunol. 3:130.

Dráberová, L., E. Dráberová, Z. Surviladze, and P. Dráber. 1999. Protein tyrosine kinase p53/p56(lyn) forms complexes with gamma-tubulin in rat basophilic leukemia cells. Int Immunol. 11:1829-1839.

Duff, D., and A. Long. 2017. Roles for RACK1 in cancer cell migration and invasion. Cell Signal. 35:250-255.

Enerbäck, L. 1966. Mast cells in rat gastrointestinal mucosa. 2. Dye-binding and metachromatic properties. Acta Pathol Microbiol Scand. 66:303-312.

Enoki, T.A., F.A. Heberle, and G.W. Feigenson. 2018. FRET Detects the Size of Nanodomains for Coexisting Liquid-Disordered and Liquid-Ordered Phases. Biophys $J$. 114:1921-1935.

Feuk-Lagerstedt, E., C. Movitz, S. Pellmé, C. Dahlgren, and A. Karlsson. 2007. Lipid raft proteome of the human neutrophil azurophil granule. Proteomics. 7:194-205.

Finkelman, F.D., M.V. Khodoun, and R. Strait. 2016. Human IgE-independent systemic anaphylaxis. J Allergy Clin Immunol. 137:1674-1680.

Freitas-Filho, E., L.A.M. Jaca, L.C. Baeza, C.M.d.A. Soares, C.L. Borges, C. Oliver, and M.C. Jamur. 2019. Proteomic analysis of lipid rafts from RBL-2H3 mast cells. Int. J. Mol. Sci. 20,3904.

Freitas-Filho, E.G., E.Z. da Silva, C.Z. Zanotto, C. Oliver, and M.C. Jamur. 2016. CrossLinking Mast Cell Specific Gangliosides Stimulates the Release of Newly Formed Lipid Mediators and Newly Synthesized Cytokines. Mediators Inflamm. 2016:9160540.

Frigeri, L., and J.R. Apgar. 1999. The role of actin microfilaments in the down-regulation of the degranulation response in RBL-2H3 mast cells. J Immunol. 162:2243-2250.

Furuno, T., N. Shinkai, Y. Inoh, and M. Nakanishi. 2015. Impaired expression of the mitochondrial calcium uniporter suppresses mast cell degranulation. Mol Cell Biochem. 410:215-221.

Galli, S.J. 2016. The Mast Cell-IgE Paradox: From Homeostasis to Anaphylaxis. Am J Pathol. 186:212-224. 
Galli, S.J., M. Grimbaldeston, and M. Tsai. 2008. Immunomodulatory mast cells: negative, as well as positive, regulators of immunity. Nat Rev Immunol. 8:478-486.

Galli, S.J., and M. Tsai. 2008. Mast cells: versatile regulators of inflammation, tissue remodeling, host defense and homeostasis. J Dermatol Sci. 49:7-19.

Gallina, A., F. Rossi, and G. Milanesi. 2001. Rack1 binds HIV-1 Nef and can act as a Nefprotein kinase C adaptor. Virology. 283:7-18.

Gilfillan, A.M., and M.A. Beaven. 2011. Regulation of mast cell responses in health and disease. Crit Rev Immunol. 31:475-529.

Grodzki, A.C., K.D. Moon, E.H. Berenstein, and R.P. Siraganian. 2009. FcepsilonRI-induced activation by low antigen concentrations results in nuclear signals in the absence of degranulation. Mol Immunol. 46:2539-2547.

Guillemot, F., A. Billault, and C. Auffray. 1989. Physical linkage of a guanine nucleotidebinding protein-related gene to the chicken major histocompatibility complex. Proc Natl Acad Sci U S A. 86:4594-4598.

Guo, N.H., G.R. Her, V.N. Reinhold, M.J. Brennan, R.P. Siraganian, and V. Ginsburg. 1989. Monoclonal antibody AA4, which inhibits binding of IgE to high affinity receptors on rat basophilic leukemia cells, binds to novel alpha-galactosyl derivatives of ganglioside GD1b. $J$ Biol Chem. 264:13267-13272.

Gupta, N., B. Wollscheid, J.D. Watts, B. Scheer, R. Aebersold, and A.L. DeFranco. 2006. Quantitative proteomic analysis of B cell lipid rafts reveals that ezrin regulates antigen receptor-mediated lipid raft dynamics. Nat Immunol. 7:625-633.

Head, B.P., H.H. Patel, and P.A. Insel. 2014. Interaction of membrane/lipid rafts with the cytoskeleton: impact on signaling and function: membrane/lipid rafts, mediators of cytoskeletal arrangement and cell signaling. Biochim Biophys Acta. 1838:532-545.

Hermans, M., J.R.V. Lennep, P. van Daele, and I. Bot. 2019. Mast Cells in Cardiovascular Disease: From Bench to Bedside. Int J Mol Sci. 20.

Hirabayashi, T., and T. Shimizu. 2000. Localization and regulation of cytosolic phospholipase A(2). Biochim Biophys Acta. 1488:124-138.

Holowka, D., and B. Baird. 2001. Fc(epsilon)RI as a paradigm for a lipid raft-dependent receptor in hematopoietic cells. Semin Immunol. 13:99-105.

Holowka, D., and B. Baird. 2015. Nanodomains in early and later phases of FceRI signalling. Essays Biochem. 57:147-163.

Holowka, D., N. Calloway, R. Cohen, D. Gadi, J. Lee, N.L. Smith, and B. Baird. 2012. Roles for $\mathrm{ca}(2+)$ mobilization and its regulation in mast cell functions. Front Immunol. 3:104.

Holowka, D., M. Wilkes, C. Stefan, and B. Baird. 2016. Roles for Ca2+ mobilization and its regulation in mast cell functions: recent progress. Biochem Soc Trans. 44:505-509. 
Hoth, M., and R. Penner. 1993. Calcium release-activated calcium current in rat mast cells. $J$ Physiol. 465:359-386.

Hwang, S., S.W. Son, S.C. Kim, Y.J. Kim, H. Jeong, and D. Lee. 2008. A protein interaction network associated with asthma. J Theor Biol. 252:722-731.

Inder, K.L., M. Davis, and M.M. Hill. 2013. Ripples in the pond--using a systems approach to decipher the cellular functions of membrane microdomains. Mol Biosyst. 9:330-338.

Irani, A.A., N.M. Schechter, S.S. Craig, G. DeBlois, and L.B. Schwartz. 1986. Two types of human mast cells that have distinct neutral protease compositions. Proc Natl Acad Sci U S A. 83:4464-4468.

Izushi, K., Y. Fujiwara, and K. Tasaka. 1992. Identification of vimentin in rat peritoneal mast cells and its phosphorylation in association with histamine release. Immunopharmacology. 23:153-161.

Jamur, M.C., A.C. Grodzki, E.H. Berenstein, M.M. Hamawy, R.P. Siraganian, and C. Oliver. 2005. Identification and characterization of undifferentiated mast cells in mouse bone marrow. Blood. 105:4282-4289.

Jamur, M.C., A.N. Moreno, L.F. Mello, D.A. Souza Júnior, M.R. Campos, M.V. Pastor, A.C. Grodzki, D.C. Silva, and C. Oliver. 2010. Mast cell repopulation of the peritoneal cavity: contribution of mast cell progenitors versus bone marrow derived committed mast cell precursors. BMC Immunol. 11:32.

Jamur, M.C., and C. Oliver. 2011. Origin, maturation and recruitment of mast cell precursors. Front Biosci (Schol Ed). 3:1390-1406.

Jia, D., F. Duan, P. Peng, L. Sun, X. Liu, L. Wang, W. Wu, Y. Ruan, and J. Gu. 2013. Upregulation of RACK1 by TGF- $\beta 1$ promotes hepatic fibrosis in mice. PLoS One. 8:e60115.

Jia, J.Y., S. Lamer, M. Schümann, M.R. Schmidt, E. Krause, and V. Haucke. 2006.

Quantitative proteomics analysis of detergent-resistant membranes from chemical synapses: evidence for cholesterol as spatial organizer of synaptic vesicle cycling. Mol Cell Proteomics. 5:2060-2071.

Jia, X., L. Zhang, and X. Mao. 2015. S-propranolol protected H9C2 cells from ischemia/reperfusion-induced apoptosis via downregultion of RACK1 Gene. Int J Clin Exp Pathol. 8:10335-10344.

Jones, M.K., A. Nair, and M. Gupta. 2019. Mast Cells in Neurodegenerative Disease. Front Cell Neurosci. 13:171.

Joulia, R., F.E. L'Faqihi, S. Valitutti, and E. Espinosa. 2017. IL-33 fine tunes mast cell degranulation and chemokine production at the single-cell level. J Allergy Clin Immunol. 140:497-509.e410.

Kadrmas, J.L., M.A. Smith, S.M. Pronovost, and M.C. Beckerle. 2007. Characterization of RACK1 function in Drosophila development. Dev Dyn. 236:2207-2215. 
Kambe, N., H. Hiramatsu, M. Shimonaka, H. Fujino, R. Nishikomori, T. Heike, M. Ito, K. Kobayashi, Y. Ueyama, N. Matsuyoshi, Y. Miyachi, and T. Nakahata. 2004. Development of both human connective tissue-type and mucosal-type mast cells in mice from hematopoietic stem cells with identical distribution pattern to human body. Blood. 103:860-867.

Kato, N., M. Nakanishi, and N. Hirashima. 2003. Cholesterol depletion inhibits store-operated calcium currents and exocytotic membrane fusion in RBL-2H3 cells. Biochemistry. 42:1180811814.

Kiely, P.A., D. O'Gorman, K. Luong, D. Ron, and R. O'Connor. 2006. Insulin-like growth factor I controls a mutually exclusive association of RACK1 with protein phosphatase $2 \mathrm{~A}$ and beta1 integrin to promote cell migration. Mol Cell Biol. 26:4041-4051.

Klebanovych, A., V. Sládková, T. Sulimenko, V. Vosecká, M. Čapek, E. Dráberová, P. Dráber, and V. Sulimenko. 2019. Regulation of Microtubule Nucleation in Mouse Bone Marrow-Derived Mast Cells by Protein Tyrosine Phosphatase SHP-1. Cells. 8.

Klein, O., and R. Sagi-Eisenberg. 2019. Anaphylactic Degranulation of Mast Cells: Focus on Compound Exocytosis. J Immunol Res. 2019:9542656.

Kolter, T. 2012. Ganglioside biochemistry. ISRN Biochem. 2012:506160.

Kovárová, M., P. Tolar, R. Arudchandran, L. Dráberová, J. Rivera, and P. Dráber. 2001. Structure-function analysis of Lyn kinase association with lipid rafts and initiation of early signaling events after Fcepsilon receptor I aggregation. Mol Cell Biol. 21:8318-8328.

Krystel-Whittemore, M., K.N. Dileepan, and J.G. Wood. 2015. Mast Cell: A Multi-Functional Master Cell. Front Immunol. 6:620.

Levental, I., M. Grzybek, and K. Simons. 2010. Greasing their way: lipid modifications determine protein association with membrane rafts. Biochemistry. 49:6305-6316.

Levental, K.R., and I. Levental. 2015. Giant plasma membrane vesicles: models for understanding membrane organization. Curr Top Membr. 75:25-57.

Li, J.J., and D. Xie. 2015. RACK1, a versatile hub in cancer. Oncogene. 34:1890-1898.

Lin, S.L., C.W. Chien, C.L. Han, E.S. Chen, S.H. Kao, Y.J. Chen, and F. Liao. 2010. Temporal proteomics profiling of lipid rafts in CCR6-activated T cells reveals the integration of actin cytoskeleton dynamics. J Proteome Res. 9:283-297.

Lingwood, D., and K. Simons. 2010. Lipid rafts as a membrane-organizing principle. Science. 327:46-50.

Liou, J., M.L. Kim, W.D. Heo, J.T. Jones, J.W. Myers, J.E. Ferrell, and T. Meyer. 2005. STIM is a Ca2+ sensor essential for Ca2+-store-depletion-triggered $\mathrm{Ca} 2+$ influx. Curr Biol. 15:1235-1241.

Liu, Y., G. Yan, M. Gao, and X. Zhang. 2018. Magnetic capture of polydopamineencapsulated Hela cells for the analysis of cell surface proteins. J Proteomics. 172:76-81. 
Luker, A.J., J.C. Lownik, D.H. Conrad, and R.K. Martin. 2019. A new look at IgE beyond allergies. F1000Res. 8.

Ma, H.T., and M.A. Beaven. 2009. Regulation of Ca2+ signaling with particular focus on mast cells. Crit Rev Immunol. 29:155-186.

Man, P., P. Novák, M. Cebecauer, O. Horváth, A. Fiserová, V. Havlícek, and K. Bezouska. 2005. Mass spectrometric analysis of the glycosphingolipid-enriched microdomains of rat natural killer cells. Proteomics. 5:113-122.

Manorak, W., C. Idahosa, K. Gupta, S. Roy, R. Panettieri, and H. Ali. 2018. Upregulation of Mas-related G Protein coupled receptor X2 in asthmatic lung mast cells and its activation by the novel neuropeptide hemokinin-1. Respir Res. 19:1.

Mark Duffy, S., P. Berger, G. Cruse, W. Yang, S.J. Bolton, and P. Bradding. 2004. The K+ channel iKCA1 potentiates $\mathrm{Ca} 2+$ influx and degranulation in human lung mast cells. J Allergy Clin Immunol. 114:66-72.

Marshall, J.S. 2004. Mast-cell responses to pathogens. Nat Rev Immunol. 4:787-799.

Masserini, M., and E. Freire. 1986. Thermotropic characterization of phosphatidylcholine vesicles containing ganglioside GM1 with homogeneous ceramide chain length. Biochemistry. 25:1043-1049.

Mazucato, V.M., A.M. Silveira E Souza, L.M. Nicoletti, M.C. Jamur, and C. Oliver. 2011. GD1b-derived gangliosides modulate FceRI endocytosis in mast cells. J Histochem Cytochem. 59:428-440.

Metcalfe, D.D., R.D. Peavy, and A.M. Gilfillan. 2009. Mechanisms of mast cell signaling in anaphylaxis. J Allergy Clin Immunol. 124:639-646; quiz 647-638.

Metzger, H., G. Alcaraz, J.P. Kinet, and R. Quarto. 1986. The receptor for immunoglobulin E as a membrane protein. Biochem Soc Symp. 51:59-67.

Minoguchi, K., W.D. Swaim, E.H. Berenstein, and R.P. Siraganian. 1994. Src family tyrosine kinase p53/56lyn, a serine kinase and Fc epsilon RI associate with alpha-galactosyl derivatives of ganglioside GD1b in rat basophilic leukemia RBL-2H3 cells. J Biol Chem. 269:5249-5254.

Minogue, S., and M.G. Waugh. 2012. Lipid rafts, microdomain heterogeneity and interorganelle contacts: impacts on membrane preparation for proteomic studies. Biol Cell. 104:618-627.

Mohamed, A., H. Robinson, P.J. Erramouspe, and M.M. Hill. 2018. Advances and challenges in understanding the role of the lipid raft proteome in human health. Expert Rev Proteomics. 15:1053-1063.

Mohamed, A., A.D. Shah, D. Chen, and M.M. Hill. 2019. RaftProt V2: understanding membrane microdomain function through lipid raft proteomes. Nucleic Acids Res. 47:D459D463. 
Moon, T.C., A.D. Befus, and M. Kulka. 2014. Mast cell mediators: their differential release and the secretory pathways involved. Front Immunol. 5:569.

Moreno, A.N., M.C. Jamur, C. Oliver, and M.C. Roque-Barreira. 2003. Mast cell degranulation induced by lectins: effect on neutrophil recruitment. Int Arch Allergy Immunol. 132:221-230.

Mukai, K., M. Tsai, H. Saito, and S.J. Galli. 2018. Mast cells as sources of cytokines, chemokines, and growth factors. Immunol Rev. 282:121-150.

Méndez-Enríquez, E., and J. Hallgren. 2019. Mast Cells and Their Progenitors in Allergic Asthma. Front Immunol. 10:821.

Nahm, D.H., C. Tkaczyk, N. Fukuishi, E. Colucci-Guyon, A.M. Gilfillan, and D.D. Metcalfe. 2003. Identification of Fyn-binding proteins in MC/9 mast cells using mass spectrometry. Biochem Biophys Res Commun. 310:202-208.

Neasta, J., P.A. Kiely, D.Y. He, D.R. Adams, R. O'Connor, and D. Ron. 2012. Direct interaction between scaffolding proteins RACK1 and 14-3-3 $\zeta$ regulates brain-derived neurotrophic factor (BDNF) transcription. J Biol Chem. 287:322-336.

Nebl, T., K.N. Pestonjamasp, J.D. Leszyk, J.L. Crowley, S.W. Oh, and E.J. Luna. 2002. Proteomic analysis of a detergent-resistant membrane skeleton from neutrophil plasma membranes. J Biol Chem. 277:43399-43409.

Negoro, T., S. Shimizu, M. Narushima, A.H. Banham, H. Wakabayashi, R. Takayanagi, T. Hagiwara, G. Roncador, T. Osabe, T. Yanai, M. Kin, K. Ikeda, A. Endo, H. Akiyama, and Y. Nakano. 2014. Elevated receptor for activated $\mathrm{C}$ kinase 1 expression is involved in intracellular $\mathrm{Ca} 2+$ influx and potentially associated with compromised regulatory $\mathrm{T}$ cell function in patients with asthma. Clin Exp Allergy. 44:1154-1169.

Nilsson, G., M. Johnell, C.H. Hammer, H.L. Tiffany, K. Nilsson, D.D. Metcalfe, A. Siegbahn, and P.M. Murphy. 1996. C3a and C5a are chemotaxins for human mast cells and act through distinct receptors via a pertussis toxin-sensitive signal transduction pathway. $J$ Immunol. 157:1693-1698.

Nishida, K., S. Yamasaki, Y. Ito, K. Kabu, K. Hattori, T. Tezuka, H. Nishizumi, D. Kitamura, R. Goitsuka, R.S. Geha, T. Yamamoto, T. Yagi, and T. Hirano. 2005. Fc\{epsilon\}RImediated mast cell degranulation requires calcium-independent microtubule-dependent translocation of granules to the plasma membrane. J Cell Biol. 170:115-126.

O'Donovan, H.C., P.A. Kiely, and R. O'Connor. 2007. Effects of RACK1 on cell migration and IGF-I signalling in cardiomyoctes are not dependent on an association with the IGF-IR. Cell Signal. 19:2588-2595.

Ogawa, K., T. Nabe, H. Yamamura, and S. Kohno. 1999. Nanomolar concentrations of neuropeptides induce histamine release from peritoneal mast cells of a substrain of Wistar rats. Eur J Pharmacol. 374:285-291.

Oliver, C., A. Fujimura, A.M. Silveira E Souza, R. Orlandini de Castro, R.P. Siraganian, and M.C. Jamur. 2007. Mast cell-specific gangliosides and FcepsilonRI follow the same endocytic pathway from lipid rafts in RBL-2H3 cells. J Histochem Cytochem. 55:315-325. 
Oliver, C., N. Sahara, S. Kitani, A.R. Robbins, L.M. Mertz, and R.P. Siraganian. 1992. Binding of monoclonal antibody AA4 to gangliosides on rat basophilic leukemia cells produces changes similar to those seen with Fc epsilon receptor activation. $J$ Cell Biol. 116:635-646.

Owen, D.M., C. Rentero, A. Magenau, A. Abu-Siniyeh, and K. Gaus. 2012. Quantitative imaging of membrane lipid order in cells and organisms. Nat Protoc. 7:24-35.

Padanilam, B.J. 2001. Induction and subcellular localization of protein kinase C isozymes following renal ischemia. Kidney Int. 59:1789-1797.

Pass, J.M., J. Gao, W.K. Jones, W.B. Wead, X. Wu, J. Zhang, C.P. Baines, R. Bolli, Y.T. Zheng, I.G. Joshua, and P. Ping. 2001. Enhanced PKC beta II translocation and PKC beta IIRACK1 interactions in PKC epsilon-induced heart failure: a role for RACK1. Am J Physiol Heart Circ Physiol. 281:H2500-2510.

Pecht, I. 2018. Immuno-receptors: from recognition to signaling and function. Eur Biophys $J$. 47:363-371.

Pejler, G. 2019. The emerging role of mast cell proteases in asthma. Eur Respir J.

Phamluong, K., E. Darcq, S. Wu, S.A. Sakhai, and D. Ron. 2017. Fyn Signaling Is

Compartmentalized to Dopamine D1 Receptor Expressing Neurons in the Dorsal Medial Striatum. Front Mol Neurosci. 10:273.

Pike, L.J. 2009. The challenge of lipid rafts. J Lipid Res. 50 Suppl:S323-328.

Prakriya, M., S. Feske, Y. Gwack, S. Srikanth, A. Rao, and P.G. Hogan. 2006. Orai1 is an essential pore subunit of the CRAC channel. Nature. 443:230-233.

Pu, Y., Y. Liu, S. Liao, S. Miao, L. Zhou, and L. Wan. 2018. Azithromycin ameliorates OVAinduced airway remodeling in Balb/c mice via suppression of epithelial-to-mesenchymal transition. Int Immunopharmacol. 58:87-93.

Reuter, S., M. Stassen, and C. Taube. 2010. Mast cells in allergic asthma and beyond. Yonsei Med J. 51:797-807.

Reynolds, D.S., R.L. Stevens, W.S. Lane, M.H. Carr, K.F. Austen, and W.E. Serafin. 1990. Different mouse mast cell populations express various combinations of at least six distinct mast cell serine proteases. Proc Natl Acad Sci U S A. 87:3230-3234.

Rivera, J., R. Arudchandran, C. Gonzalez-Espinosa, T.S. Manetz, and S. Xirasagar. 2001. A perspective: regulation of IgE receptor-mediated mast cell responses by a LAT-organized plasma membrane-localized signaling complex. Int Arch Allergy Immunol. 124:137-141.

Rollins, M.G., S. Jha, E.T. Bartom, and D. Walsh. 2019. RACK1 evolved species-specific multifunctionality in translational control through sequence plasticity within a loop domain. $J$ Cell Sci. 132.

Ron, D., D.R. Adams, G.S. Baillie, A. Long, R. O'Connor, and P.A. Kiely. 2013. RACK1 to the future--a historical perspective. Cell Commun Signal. 11:53. 
Ron, D., C.H. Chen, J. Caldwell, L. Jamieson, E. Orr, and D. Mochly-Rosen. 1994. Cloning of an intracellular receptor for protein kinase $\mathrm{C}$ : a homolog of the beta subunit of $\mathrm{G}$ proteins. Proc Natl Acad Sci U S A. 91:839-843.

Ron, D., J. Luo, and D. Mochly-Rosen. 1995. C2 region-derived peptides inhibit translocation and function of beta protein kinase C in vivo. J Biol Chem. 270:24180-24187.

Rudich, N., K. Ravid, and R. Sagi-Eisenberg. 2012. Mast cell adenosine receptors function: a focus on the a3 adenosine receptor and inflammation. Front Immunol. 3:134.

Sandig, H., and S. Bulfone-Paus. 2012. TLR signaling in mast cells: common and unique features. Front Immunol. 3:185.

Serrels, B., E. Sandilands, and M.C. Frame. 2011. Signaling of the direction-sensing FAK/RACK1/PDE4D5 complex to the small GTPase Rap1. Small GTPases. 2:54-61.

Settipane, R.A., A.T. Peters, and L. Borish. 2013. Chapter 17: Immunomodulation of allergic sinonasal disease. Am J Rhinol Allergy. 27 Suppl 1:S59-62.

Sezgin, E. 2017. Super-resolution optical microscopy for studying membrane structure and dynamics. J Phys Condens Matter. 29:273001.

Sezgin, E., I. Levental, S. Mayor, and C. Eggeling. 2017. The mystery of membrane organization: composition, regulation and roles of lipid rafts. Nat Rev Mol Cell Biol. 18:361374.

Sheets, E.D., D. Holowka, and B. Baird. 1999. Critical role for cholesterol in Lyn-mediated tyrosine phosphorylation of FcepsilonRI and their association with detergent-resistant membranes. J Cell Biol. 145:877-887.

Silveira e Souza, A.M., V.M. Mazucato, R.O. de Castro, F. Matioli, P. Ciancaglini, T. de Paiva Paulino, M.C. Jamur, and C. Oliver. 2008. The alpha-galactosyl derivatives of ganglioside GD(1b) are essential for the organization of lipid rafts in RBL-2H3 mast cells. Exp Cell Res. 314:2515-2528.

Silveira E Souza, A.M., V.M. Mazucato, M.C. Jamur, and C. Oliver. 2011. Lipid rafts in mast cell biology. J Lipids. 2011:752906.

Simons, K., and G. van Meer. 1988. Lipid sorting in epithelial cells. Biochemistry. 27:61976202.

Siraganian, R.P., R.O. de Castro, E.A. Barbu, and J. Zhang. 2010. Mast cell signaling: the role of protein tyrosine kinase Syk, its activation and screening methods for new pathway participants. FEBS Lett. 584:4933-4940.

Smith, P.R., O. de Jesus, D. Turner, M. Hollyoake, C.E. Karstegl, B.E. Griffin, L. Karran, Y. Wang, S.D. Hayward, and P.J. Farrell. 2000. Structure and coding content of CST (BART) family RNAs of Epstein-Barr virus. J Virol. 74:3082-3092.

Sonnino, S., A. Prinetti, H. Nakayama, M. Yangida, H. Ogawa, and K. Iwabuchi. 2009. Role of very long fatty acid-containing glycosphingolipids in membrane organization and cell signaling: the model of lactosylceramide in neutrophils. Glycoconj J. 26:615-621. 
Stephan, V., A. Seibt, D. Dukanovic, M. Skasa, W.D. Swaim, E.H. Berenstein, R.P. Siraganian, and V. Wahn. 1997. Anti-ganglioside monoclonal antibody AA4 selectively inhibits IgE-induced signal transduction pathways in rat basophilic leukemia cells. Mol Immunol. 34:227-235.

Subramanian, H., K. Gupta, and H. Ali. 2016. Roles of Mas-related G protein-coupled receptor X2 on mast cell-mediated host defense, pseudoallergic drug reactions, and chronic inflammatory diseases. J Allergy Clin Immunol. 138:700-710.

Sulimenko, V., E. Dráberová, T. Sulimenko, L. Macurek, V. Richterová, and P. Dráber. 2006. Regulation of microtubule formation in activated mast cells by complexes of gamma-tubulin with Fyn and Syk kinases. J Immunol. 176:7243-7253.

Sulimenko, V., Z. Hájková, M. Černohorská, T. Sulimenko, V. Sládková, L. Dráberová, S. Vinopal, E. Dráberová, and P. Dráber. 2015. Microtubule nucleation in mouse bone marrowderived mast cells is regulated by the concerted action of GIT1/ $\beta$ PIX proteins and calcium. $J$ Immunol. 194:4099-4111.

Sutton, P., J.A. Borgia, P. Bonomi, and J.M. Plate. 2013. Lyn, a Src family kinase, regulates activation of epidermal growth factor receptors in lung adenocarcinoma cells. Mol Cancer. $12: 76$.

Suzuki, K.G.N., H. Ando, N. Komura, T. Fujiwara, M. Kiso, and A. Kusumi. 2018. Unraveling of Lipid Raft Organization in Cell Plasma Membranes by Single-Molecule Imaging of Ganglioside Probes. Adv Exp Med Biol. 1104:41-58.

Suzuki, R., S. Leach, W. Liu, E. Ralston, J. Scheffel, W. Zhang, C.A. Lowell, and J. Rivera. 2014. Molecular editing of cellular responses by the high-affinity receptor for IgE. Science. 343:1021-1025.

Suzuki, R., X. Liu, A. Olivera, L. Aguiniga, Y. Yamashita, U. Blank, I. Ambudkar, and J. Rivera. 2010. Loss of TRPC1-mediated $\mathrm{Ca} 2+$ influx contributes to impaired degranulation in Fyn-deficient mouse bone marrow-derived mast cells. J Leukoc Biol. 88:863-875.

Swaim, W.D., K. Minoguchi, C. Oliver, M.M. Hamawy, H. Kihara, V. Stephan, E.H. Berenstein, and R.P. Siraganian. 1994. The anti-ganglioside monoclonal antibody AA4 induces protein tyrosine phosphorylations, but not degranulation, in rat basophilic leukemia cells. J Biol Chem. 269:19466-19473.

Tarnowski, K., K. Fituch, R.H. Szczepanowski, M. Dadlez, and M. Kaus-Drobek. 2014. Patterns of structural dynamics in RACK1 protein retained throughout evolution: a hydrogendeuterium exchange study of three orthologs. Protein Sci. 23:639-651.

Tasaka, K. 1994. Molecular mechanism of histamine release: the role of intermediate filaments and membrane skeletons. J Physiol Pharmacol. 45:479-492.

Tasaka, K., M. Akagi, M. Mio, K. Miyoshi, and I. Aoki. 1991. The existence of filaments connecting the granules and the cell membrane in rat peritoneal mast cells. Agents Actions. $33: 48-52$.

Tasaka, K., M. Akagi, and K. Miyoshi. 1986a. Distribution of actin filaments in rat mast cells and its role in histamine release. Agents Actions. 18:49-52. 
Tasaka, K., M. Mio, and M. Okamoto. 1986b. Changes in intracellular Ca2+ distribution of rat peritoneal mast cells before and after histamine release. Agents Actions. 18:61-64.

Tolarová, H., L. Dráberová, P. Heneberg, and P. Dráber. 2004. Involvement of filamentous actin in setting the threshold for degranulation in mast cells. Eur J Immunol. 34:1627-1636.

Ullah, H., W. Hou, S. Dakshanamurthy, and Q. Tang. 2019. Host targeted antiviral (HTA): functional inhibitor compounds of scaffold protein RACK1 inhibit herpes simplex virus proliferation. Oncotarget. 10:3209-3226.

Valerius, O., M. Kleinschmidt, N. Rachfall, F. Schulze, S. López Marín, M. Hoppert, K. Streckfuss-Bömeke, C. Fischer, and G.H. Braus. 2007. The Saccharomyces homolog of mammalian RACK1, Cpc2/Asc1p, is required for FLO11-dependent adhesive growth and dimorphism. Mol Cell Proteomics. 6:1968-1979.

Varshney, P., V. Yadav, and N. Saini. 2016. Lipid rafts in immune signalling: current progress and future perspective. Immunology. 149:13-24.

Vennekens, R., J. Olausson, M. Meissner, W. Bloch, I. Mathar, S.E. Philipp, F. Schmitz, P. Weissgerber, B. Nilius, V. Flockerzi, and M. Freichel. 2007. Increased IgE-dependent mast cell activation and anaphylactic responses in mice lacking the calcium-activated nonselective cation channel TRPM4. Nat Immunol. 8:312-320.

Vig, M., W.I. DeHaven, G.S. Bird, J.M. Billingsley, H. Wang, P.E. Rao, A.B. Hutchings, M.H. Jouvin, J.W. Putney, and J.P. Kinet. 2008. Defective mast cell effector functions in mice lacking the CRACM1 pore subunit of store-operated calcium release-activated calcium channels. Nat Immunol. 9:89-96.

Volta, V., A. Beugnet, S. Gallo, L. Magri, D. Brina, E. Pesce, P. Calamita, F. Sanvito, and S. Biffo. 2013. RACK1 depletion in a mouse model causes lethality, pigmentation deficits and reduction in protein synthesis efficiency. Cell Mol Life Sci. 70:1439-1450.

Wang, F., T. Osawa, R. Tsuchida, Y. Yuasa, and M. Shibuya. 2011. Downregulation of receptor for activated C-kinase 1 (RACK1) suppresses tumor growth by inhibiting tumor cell proliferation and tumor-associated angiogenesis. Cancer Sci. 102:2007-2013.

Wang, S., J.Z. Chen, Z. Zhang, S. Gu, C. Ji, R. Tang, K. Ying, Y. Xie, and Y. Mao. 2003. Cloning, expression and genomic structure of a novel human GNB2L1 gene, which encodes a receptor of activated protein kinase C (RACK). Mol Biol Rep. 30:53-60.

Wernersson, S., and G. Pejler. 2014. Mast cell secretory granules: armed for battle. Nat Rev Immunol. 14:478-494.

Wilson, J.D., S.A. Shelby, D. Holowka, and B. Baird. 2016. Rab11 Regulates the Mast Cell Exocytic Response. Traffic. 17:1027-1041.

Wollman, R., and T. Meyer. 2012. Coordinated oscillations in cortical actin and Ca2+ correlate with cycles of vesicle secretion. Nat Cell Biol. 14:1261-1269.

Wollscheid, B., P.D. von Haller, E. Yi, S. Donohoe, K. Vaughn, A. Keller, A.I. Nesvizhskii, J. Eng, X.J. Li, D.R. Goodlett, R. Aebersold, and J.D. Watts. 2004. Lipid raft proteins and their identification in T lymphocytes. Subcell Biochem. 37:121-152. 
Woodard, G.E., J.J. López, I. Jardín, G.M. Salido, and J.A. Rosado. 2010. TRPC3 regulates agonist-stimulated $\mathrm{Ca} 2+$ mobilization by mediating the interaction between type I inositol 1,4,5-trisphosphate receptor, RACK1, and Orai1. J Biol Chem. 285:8045-8053.

Xing, W., K.F. Austen, M.F. Gurish, and T.G. Jones. 2011. Protease phenotype of constitutive connective tissue and of induced mucosal mast cells in mice is regulated by the tissue. Proc Natl Acad Sci U S A. 108:14210-14215.

Yanase, Y., I. Hide, S. Mihara, Y. Shirai, N. Saito, Y. Nakata, M. Hide, and N. Sakai. 2011. A critical role of conventional protein kinase $\mathrm{C}$ in morphological changes of rodent mast cells. Immunol Cell Biol. 89:149-159.

Yao, F., L.Y. Long, Y.Z. Deng, Y.Y. Feng, G.Y. Ying, W.D. Bao, G. Li, D.X. Guan, Y.Q. Zhu, J.J. Li, and D. Xie. 2014. RACK1 modulates NF-кB activation by interfering with the interaction between TRAF2 and the IKK complex. Cell Res. 24:359-371.

Yong, L.C. 1997. The mast cell: origin, morphology, distribution, and function. Exp Toxicol Pathol. 49:409-424.

Zakrzewicz, A., M. Hecker, L.M. Marsh, G. Kwapiszewska, B. Nejman, L. Long, W. Seeger, R.T. Schermuly, N.W. Morrell, R.E. Morty, and O. Eickelberg. 2007. Receptor for activated C-kinase 1, a novel interaction partner of type II bone morphogenetic protein receptor, regulates smooth muscle cell proliferation in pulmonary arterial hypertension. Circulation. 115:2957-2968.

Zhang, N., A.R. Shaw, N. Li, R. Chen, A. Mak, X. Hu, N. Young, D. Wishart, and L. Li. 2008. Liquid chromatography electrospray ionization and matrix-assisted laser desorption ionization tandem mass spectrometry for the analysis of lipid raft proteome of monocytes. Anal Chim Acta. 627:82-90.

Zhao, Y., Q. Wang, G. Qiu, S. Zhou, Z. Jing, J. Wang, W. Wang, J. Cao, K. Han, Q. Cheng, B. Shen, Y. Chen, W.J. Zhang, Y. Ma, and J. Zhang. 2015. RACK1 Promotes Autophagy by Enhancing the Atg14L-Beclin 1-Vps34-Vps15 Complex Formation upon Phosphorylation by AMPK. Cell Rep. 13:1407-1417.

Zhou, Y., P. Srinivasan, S. Razavi, S. Seymour, P. Meraner, A. Gudlur, P.B. Stathopulos, M. Ikura, A. Rao, and P.G. Hogan. 2013. Initial activation of STIM1, the regulator of storeoperated calcium entry. Nat Struct Mol Biol. 20:973-981. 


\title{
Adaptor protein-3: A key player in RBL-2H3 mast cell mediator release
}

\author{
Elaine Zayas Marcelino da Silva, Edismauro Garcia Freitas-Filho, Devandir Antonio de \\ Souza-Júnior, Luis Lamberti Pinto daSilva, Maria Celia Jamur, Constance Oliver* \\ Department of Cell and Molecular Biology and Pathogenic Bioagents, Ribeirão Preto Medical School - \\ University of São Paulo, Ribeirão Preto, São Paulo, Brazil \\ * coliver@fmrp.usp.br
}

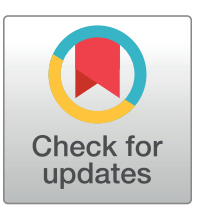

\section{OPEnACCESS}

Citation: da Silva EZM, Freitas-Filho EG, de SouzaJúnior DA, daSilva LLP, Jamur MC, Oliver C (2017) Adaptor protein-3: A key player in RBL-2H3 mast cell mediator release. PLOS ONE 12(3): e0173462. doi:10.1371/journal.pone. 0173462

Editor: Ramani Ramchandran, Medical College of Wisconsin, UNITED STATES

Received: June 22, 2016

Accepted: February 22, 2017

Published: March 8, 2017

Copyright: @ 2017 da Silva et al. This is an open access article distributed under the terms of the Creative Commons Attribution License, which permits unrestricted use, distribution, and reproduction in any medium, provided the original author and source are credited.

Data Availability Statement: All relevant data are within the paper.

Funding: This work was supported by research grants from Fundação de Amparo á Pesquisa do Estado de São Paulo (FAPESP, www.fapesp.br; EZMS: 2012/07363-0; EGFF: 2013/12861-0; MCJ: 2009/54013-0; CO: 2014/11396-5), Conselho Nacional de Desenvolvimento Científico e Tecnológico (CNPq, www.cnpq.br; EZMS: 161304/ 2011-7; DASJ: 502429/2014-3), Coordenação de Aperfeiçoamento de Pessoal de Nível Superior (Capes, www.capes.gov.br), and Fundação de

\section{Abstract}

Mast cell (MC) secretory granules are Lysosome-Related Organelles (LROs) whose biogenesis is associated with the post-Golgi secretory and endocytic pathways in which the sorting of proteins destined for a specific organelle relies on the recognition of sorting signals by adaptor proteins that direct their incorporation into transport vesicles. The adaptor protein 3 (AP-3) complex mediates protein trafficking between the trans-Golgi network (TGN) and late endosomes, lysosomes, and LROs. AP-3 has a recognized role in LROs biogenesis and regulated secretion in several cell types, including many immune cells such as neutrophils, natural killer cells, and cytotoxic T lymphocytes. However, the relevance of AP-3 for these processes in MCs has not been previously investigated. AP-3 was found to be expressed and distributed in a punctate fashion in rat peritoneal mast cells ex vivo. The rat MC line RBL-2H3 was used as a model system to investigate the role of AP-3 in mast cell secretory granule biogenesis and mediator release. By immunofluorescence and immunoelectron microscopy, AP-3 was localized both to the TGN and early endosomes indicating that AP-3 dependent sorting of proteins to $\mathrm{MC}$ secretory granules originates in these organelles. ShRNA mediated depletion of the AP-3 $\delta$ subunit was shown to destabilize the AP-3 complex in RBL-2H3 MCs. AP-3 knockdown significantly affected MC regulated secretion of $\beta$-hexosaminidase without affecting total cellular enzyme levels. Morphometric evaluation of $M C$ secretory granules by electron microscopy revealed that the area of $M C$ secretory granules in AP-3 knockdown MCs was significantly increased, indicating that AP-3 is involved in $\mathrm{MC}$ secretory granule biogenesis. Furthermore, AP-3 knockdown had a selective impact on the secretion of newly formed and newly synthesized mediators. These results show for the first time that AP-3 plays a critical role in secretory granule biogenesis and mediator release in MCs.

\section{Introduction}

Lysosome-Related Organelles (LROs) are functionally diverse cell type-specific subcellular compartments that share many features with lysosomes and are capable of regulated secretion in response to appropriate stimuli $[1,2]$. In addition to melanocytes and endothelial 
Apoio ao Ensino, Pesquisa e Assistência do Hospital das Clínicas da Faculdade de Medicina de Ribeirão Preto da Universidade de São Paulo (FAEPA, www.faepa.br). The funders had no role in study design, data collection and analysis, decision to publish, or preparation of the manuscript.

Competing interests: The authors have declared that no competing interests exist. cells, LROs are found in many specialized secretory cells of hematopoietic origin and store cell type specific secretory proteins along with lysosomal membrane proteins and hydrolases [3, 4]. LRO biogenesis originates in the biosynthetic pathway where proteins destined for regulated secretion are synthesized in the endoplasmic reticulum and transported sequentially through the Golgi apparatus were they are modified post translationally before reaching the trans-Golgi network (TGN) from which they are sorted either directly to the LROs or indirectly through the plasma membrane and the endosomal-lysosomal system $[5,6]$.

Protein targeting within the biosynthetic and endosomal-lysosomal system depends on sorting signals that direct their incorporation into transport vesicles for delivery to target organelles [7]. These vesicles display specific coat proteins that aid in the selection of cargo, mechanical bending of the donor membrane and, subsequently, vesicle budding. Clathrincoated vesicles (CCVs) are the major carriers involved in post-Golgi secretory and endocytic pathways. The formation of CCVs depends on clathrin adaptors that connect clathrin to the donor membrane, select cargo, and recruit accessory proteins, which regulate budding and vesicular trafficking $[8,9]$. Among the several classes of clathrin adaptors, the adaptor protein (AP) complexes belong to a family with five members (AP-1, AP-2, AP-3, AP-4 and AP-5), each with distinct membrane localization and functions. They act by recognizing small sequences or motifs which include tyrosine based $\operatorname{Yxx} \phi$ (where $\phi$ is either I, L, M, F, or V) or acidic dileucine motifs $[\mathrm{D} / \mathrm{E}] \mathrm{xxxL}[\mathrm{I} / \mathrm{L}]$ in the cytosolic tail of cargo proteins [10]. Lysosomal membrane proteins contain one or more of these targeting signals in their cytosolic domains that interact selectively with AP complexes to mediate their incorporation into transport vesicles $[8,11,12]$. The AP- 3 complex is composed of two large $(\delta / \beta 3)$, a medium $(\mu 3)$ and a small (б3) subunit, and is involved in the sorting and trafficking of a subset of transmembrane proteins between tubular endosomes (early endosomes) and/or TGN to late endosomes, lysosomes, and LROs. The importance of AP-3 for LRO biogenesis and regulated secretion is highlighted in Type II Hermansky-Pudlak Syndrome (HPS2), a human autosomal recessive disorder caused by genetic defects in the $\beta 3 \mathrm{~A}$ subunit of AP-3, and in its mouse model Pearl $[13,14]$. HPS2 is characterized by oculocutaneous albinism, bleeding disorders and innate immune deficiency. These symptoms are associated with anomalies in LRO biogenesis and secretion in specialized secretory cells including melanocytes, platelets, neutrophils, natural killer cells, and cytotoxic T lymphocytes [15-18].

Mast cells (MCs) are multifunctional immune cells that, in addition to their well-established role in allergic reactions, participate in innate and adaptive immunity, and inflammation among other physiological and pathological processes [19-24]. IgE-dependent MC activation, through aggregation of antigen specific IgE bound to FceRI on the MC surface, is the most common type of $\mathrm{MC}$ activation and triggers the signaling cascade that culminates in the release of three classes of mediators: preformed mediators, which are stored in mast cell secretory granules (LROs); neoformed or lipid mediators, which are newly-formed from membrane lipids; and neosynthesized mediators produced following transcriptional activation [25-27]. In spite of the recognized role of AP-3 in the biogenesis and regulated secretion of LROs in several cell types, the presence of AP- 3 and its relevance for these processes in MCs has not been previously investigated. The expression of AP-3 in MCs was confirmed using rat peritoneal mast cells. The involvement of the AP- 3 complex in LRO biogenesis and mediator release was then investigated using the RBL- $2 \mathrm{H} 3$ rat $\mathrm{MC}$ line. The AP- 3 complex was shown to be associated with the biosynthetic and endocytic pathways in RBL-2H3 MCs and to have a role in regulating secretory granule size. Furthermore, AP-3 knockdown had an impact on RBL$2 \mathrm{H} 3$ regulated exocytosis of preformed mediators and also on the secretion of some newly formed and newly synthesized mediators. 


\section{Materials and methods}

\section{Animals}

Young $(150 \mathrm{~g})$ male and female Wistar rats were used. Animals were housed and experiments were approved and conducted according to the Comissão de Ética em Experimentação Animal, Ribeirão Preto Medical School-USP, Ribeirão Preto, Brazil guidelines (protocol: 032/ 2007). For all experiments, animals were sacrificed by $\mathrm{CO}_{2}$ inhalation.

\section{Cells}

RBL-2H3 rat mast cells [28] were used in this study. Cells were grown as monolayers in Dulbecco's modified Eagle's Medium (DMEM) (Invitrogen-Thermo Fisher Scientific, Carlsbad, CA) supplemented with $15 \%$ fetal calf serum (Sigma-Aldrich, St. Louis, MO), $0.434 \mathrm{mg} / \mathrm{mL}$ glutamine, and an antibiotic-antimycotic mixture containing $100 \mathrm{U} / \mathrm{mL}$ penicillin, $100 \mu \mathrm{g} / \mathrm{mL}$ streptomycin, and $0.25 \mu \mathrm{g} / \mathrm{mL}$ amphotericin B (Invitrogen-Thermo Fisher Scientific). The HEK293T cell line [29] was used as a packaging cell line to produce lentiviral particles and was cultured under the same conditions as the RBL-2H3 cells.

\section{Antibodies}

The following primary antibodies were used: mouse mAb anti- $\delta \mathrm{SA} 4(10 \mu \mathrm{g} / \mathrm{mL}$; Developmental Studies Hybridoma Bank, Iowa City, IA; Peden et al, 2004), mouse mAb anti-rat GD1b derived gangliosides-mAb AA4 (5 $\mu \mathrm{g} / \mathrm{mL}$; Clone AR32AA4; BD Pharmingen, San Jose, CA), rabbit polyclonal antibody anti-AP3D1 (1:100; Proteintech Group, Inc., Chicago, IL), mouse mAb anti-p47A (1:500; Clone 26/P47A; BD Transduction Laboratories, San Jose, CA; generously provided by Dr. Gonzalo A. Mardones, Austral University of Chile, Chile), mouse mAb anti-Adaptin $\gamma$ (1:1000; Clone 88/Adaptin $\gamma$; BD Transduction Laboratories), rabbit mAb antiSNX2 (1:1000; [30]), mouse mAb anti-GM130 (4 $\mu \mathrm{g} / \mathrm{mL}$; Clone 35/GM130; BD Transduction Laboratories), mouse mAb anti-TGN38 (1:800; Clone 2; BD Transduction Laboratories), rabbit polyclonal antibody anti-Cathepsin D $(10 \mu \mathrm{g} / \mathrm{mL}$; Clone IM-16; Calbiochem-Merck KGaA, Darmstadt, Germany), mouse mAb anti-FceRI alpha subunit conjugated to FITC $(15 \mu \mathrm{g} / \mathrm{mL}$; Clone BC4; generously provided by Dr. Reuben Siraganian, National Institutes of Health-NIDCR, Bethesda, MD), and rabbit polyclonal antibody anti- $\alpha / \beta$-tubulin (1:5000; Cell Signaling Technology Inc., Danvers, MA). The following secondary antibodies were used for immunofluorescence and flow cytometry: donkey anti-mouse $\operatorname{IgG~F}(\mathrm{ab})^{\prime}{ }_{2}$-Alexa 488 or 594 and donkey anti-rabbit IgG F(ab) ${ }_{2}{ }_{2}$-Alexa 594 or 488 (1:1000; Molecular Probes-Thermo Fisher Scientific). The following secondary antibodies were used for immunoblotting: donkey anti-mouse IgG conjugated to horseradish peroxidase (HRP) and donkey anti-rabbit IgG conjugated to HRP (Jackson ImmunoResearch Laboratories Inc., West Grove, PA). For immunoelectron microscopy goat anti-mouse IgG conjugated to nanogold (Nanoprobes, Yaphank, NY) was used according to manufacturer's instructions. Mouse IgE anti-TNP ascites fluid was used to sensitize cells before FceRI stimulation (1:5000; generously provided by Dr. Reuben Siraganian, NIH).

\section{ShRNA knockdown}

MISSION ${ }^{\circledR}$ lentiviral shRNA plasmid vectors encoding AP- $3 \delta$ shRNA sequences and a nontargeting shRNA control vector (MISSION TRC2 pLKO.5-puro Non-Mammalian shRNA Control, Catalog No. SHC202), both also containing a puromycin resistance gene, were purchased from Sigma-Aldrich. Two premade lentiviral constructs encoding AP-3 $\delta$ shRNAs were used. The shRNAs employed were designed against the following target sequences: Clone 
23 (Sh23) 5' - TCCATGTACAGCCGCTCTATCC-3' and Clone 24 (Sh24) 5' -ACCTGGATGC CTGGATCAATG-3' . Control nontargeting Insert Sequence: $5^{\prime}$ - CCGGCAA CAAGATGAAG AGCACCAACTCGAGTTGGTGCTCTTCATCTTGTTGTTTTT- $3^{\prime}$. FuGENE ${ }^{\circledR}$ HD Transfection Reagent (Promega Co., Madison, WI) was used to co-transfect the shRNA vectors with the MISSION $^{\circledR}$ Lentiviral Packing mix (Sigma-Aldrich) into HEK293T packing cells to generate lentiviral particles. RBL-2H3 cells were transduced with control or AP-3 $\delta$ lentivirus (Sh23 and Sh24) for 16 h a a MOI of 6 . The media containing the virus was removed and replaced with fresh DMEM and the cells cultured for $24 \mathrm{~h}$ before addition of puromycin $(1 \mu \mathrm{g} / \mathrm{mL}$; SigmaAldrich) in order to select for cells in which the shRNA was integrated. Real time PCR and immunostaining of permeabilized cells followed by flow cytometry were employed to monitor AP-3 $\delta$ mRNA and protein knockdown, respectively; also, immunoblotting of $\mu 3$ subunit was employed to confirm AP-3 complex knockdown.

\section{Real-time PCR}

Total RNA was purified from $5.0 \times 10^{6}$ cells using the Illustra ${ }^{\mathrm{Tm}}$ RNAspin Mini Isolation Kit (GE Healthcare Bio-Sciences, Pittsburgh, PA) according to the manufacturer's instructions. For cDNA synthesis $5 \mu \mathrm{g}$ of total RNA was reverse-transcribed using the GoScript ${ }^{\mathrm{Tm}}$ Reverse Transcription System according to the manufacturer's instructions (Promega). Gene specific primers were used for quantitative PCR analysis. Power SYBR Green PCR Master Mix (Applied Biosystems, Thermo Fisher Scientific, Inc., Foster City, CA) was used with $10 \mathrm{ng}$ of RNA/well of the cDNA product in an ABI 7500 Real Time PCR System (Applied Biosystems, Thermo Fisher Scientific, Inc.). For all RT-PCR analysis, GAPDH mRNA was used to normalize RNA inputs. Primer sequences are as follows:

rat AP3D1 forward (5'-TGTGGAGCTGACAAGACTGG-3');
rat AP3D1 reverse (5'-ACCAGGTGGGCACTATCAAG-3');
rat GAPDH forward (5'-GACATGCCGCCTGGAGAAAC-3');
rat GAPDH reverse $\left(5^{\prime}-\right.$ AGCCCAGGATGCCCTTTAGT-3' $)$.

\section{Flow cytometry}

The cells were cultivated $\left(5.0 \times 10^{5}\right.$ cells) for $16 \mathrm{~h}$ in Costar T-25 flasks (Corning Life Sciences, Tewksbury, MA), harvested with trypsin-EDTA (Invitrogen-Thermo Fisher Scientific), and rinsed by centrifugation in PBS. To evaluate expression of AP- $3 \delta$ subunit, the cells were then fixed for 20 min with $2 \%$ paraformaldehyde (Electron Microscopy Sciences, Hatfield, PA) in PBS, washed in PBS and permeabilized with $0.05 \%$ saponin in PBS for $15 \mathrm{~min}$, blocked for 30 min at room temperature (RT) in PBS containing 1\% BSA (Sigma-Aldrich) and $5 \mu \mathrm{g} / \mathrm{mL}$ normal donkey IgG (Jackson ImmunoResearch). The cells were then incubated with primary antibody for 1h, washed 3 times with PBS and incubated with donkey anti-mouse IgG conjugated to Alexa 488 for $1 \mathrm{~h}$ at RT and washed 5 times in PBS. After rinsing, the cells were analyzed with a Guava EasyCyte Mini System using Cytosoft Blue software (Guava Technologies, Inc., Hayward, CA). To evaluate FceRI surface expression, non-permeabilized cells were incubated at $4^{\circ} \mathrm{C}$ for $1 \mathrm{~h}$ with $\mathrm{mAb}$ BC4-FITC in PBS containing $1 \%$ BSA and $5 \mathrm{mg} / \mathrm{mL}$ normal donkey IgG, washed in PBS and fixed for 20 min with $2 \%$ paraformaldehyde (Electron Microscopy Sciences) before been analyzed with a Guava EasyCyte Mini System using Cytosoft Blue software (Guava Technologies, Inc., Hayward, CA). 


\section{SDS-page and immunoblotting}

Antibodies to AP-3 $\mu$ (mouse mAb anti-p47A) and AP- $1 \gamma$ (mouse mAb anti-Adaptin $\gamma$ ) subunits where used to evaluate expression of adaptor proteins. Whole cell lysates were mixed with 2X SDS-PAGE sample buffer (4\% SDS, 20\% Glycerol, $0.12 \mathrm{M}$ Tris pH 6.8, and 5\% $\beta$-Mercaptoethanol), boiled and proteins were separated electrophoretically on $10 \%$ polyacrylamide gels and electrotransferred to Hybond nitrocellulose membranes (GE Healthcare Bio-Sciences). After transfer, the membranes were blocked for $1 \mathrm{~h}$ at RT in TTBS $(0.05 \mathrm{M}$ Tris- $\mathrm{HCl}$, $0.15 \mathrm{M} \mathrm{NaCl}, \mathrm{pH} 7.5$, and $0.05 \%$ Tween 20 ) containing $4 \% \mathrm{BSA}$ and probed for $16 \mathrm{~h}$ at $4^{\circ} \mathrm{C}$ with individual primary antibodies, washed in TTBS and incubated with the appropriate anti IgG conjugated to HRP (Jackson ImmunoResearch) for $30 \mathrm{~min}$ at RT, washed and developed using chemiluminescence (ECL-GE Healthcare Bio-Sciences). Images were obtained using a BioRad ChemiDoc Imaging System (Bio-Rad Laboratories, Hercules, CA). The mean optical density of the target protein was determined using the Image Lab software (Bio-Rad Laboratories).

\section{Fluorescence microscopy}

Peritoneal cells were obtained by injecting Wistar rats i.p. with $15 \mathrm{~mL}$ sterile PBS. The peritoneal wash was collected following laparotomy using a Pasteur pipette. The cells were rinsed twice in PBS and placed on silane-coated Unifrost Microscope Slides (Azer Scientific, Morgantown, PA). The cells were fixed for 20 min with $2 \%$ paraformaldehyde (Electron Microscopy Sciences) in PBS, rinsed again, and permeabilized with $0.01 \%$ saponin (Sigma-Aldrich) in PBS for $20 \mathrm{~min}$. Next, cells were incubated for $45 \mathrm{~min}$ at RT in PBS containing 1\% BSA and $5 \mu \mathrm{g} /$ $\mathrm{mL}$ normal donkey IgG (Jackson ImmunoResearch). For double staining with two different mouse monoclonal antibodies, $\mathrm{mAb} \delta \mathrm{SA} 4$ and $\mathrm{mAb} \mathrm{AA} 4$ were fluorescently labeled according to the manufacturer's protocol with the Zenon Alexa Fluor 488 and 594 mouse IgG1 labeling kits (Molecular Probes-Thermo Fisher Scientific), respectively. The cells were then incubated with the directly labeled antibodies for $1 \mathrm{~h}$ at RT. Cells were then rinsed in PBS and mounted with Fluoromount-G (Electron Microscopy Sciences).

RBL- $2 \mathrm{H} 3$ cells were plated $\left(5.0 \times 10^{4}\right.$ cells/coverslip) and cultured for $16 \mathrm{~h}$ on $13 \mathrm{~mm}$ round coverslips. The cells were rinsed in PBS, fixed for $20 \mathrm{~min}$ with $2 \%$ paraformaldehyde (Electron Microscopy Sciences) in PBS, rinsed again, and permeabilized with $0.01 \%$ saponin (SigmaAldrich) in PBS for $20 \mathrm{~min}$. Next, cells were rinsed twice in PBS and incubated for $45 \mathrm{~min}$ at $\mathrm{RT}$ in PBS containing $1 \% \mathrm{BSA}$ and $5 \mu \mathrm{g} / \mathrm{mL}$ normal donkey IgG (Jackson ImmunoResearch). Cells were then labeled with primary antibodies diluted in PBS containing 1\% BSA for $1 \mathrm{~h}$ at RT. To avoid cross-reactivity, two different antibodies were used to determine the subcellular localization of AP-3. In the double staining of AP-3 with GM130 and TGN38, rabbit polyclonal antibody anti-AP3D1 was used to localize AP-3 since anti-GM130 and anti-TGN38 antibodies were raised in mice. Otherwise, mouse $\mathrm{mAb}$ anti- $\delta \mathrm{SA} 4$ was used to localize AP-3 in the double staining of AP-3 with SNX2 and CATD since both anti-SNX2 and anti-CATD antibodies were raised in rabbit. After incubation, cells were rinsed thoroughly in PBS and incubated for $30 \mathrm{~min}$ at RT with the appropriate secondary antibodies diluted in PBS. Cells were then rinsed in PBS and mounted with Fluoromount-G (Electron Microscopy Sciences). Cells incubated without primary antibody served as controls and were all negative. All samples were analyzed using a LEICA TCS-NT SP5 laser scanning confocal microscope (Leica Microsystems; Heidelberg, Germany). Colocalization studies were performed on Z-series images by quantitation of Manders' Colocalization coefficients M1/M2 using Image J software [31] and the colocalization threshold plug-in developed by Tony Collins (Wright Cell Imaging Facility, Toronto, Canada) as previously described [32]. M1 is the percentage of above-background pixels in the green channel that overlap above-background pixels in the red channel. 
Immunostaining of the $\delta$ subunit of AP- 3 was considered the green channel and the organelle marker was considered the red channel. The organelle markers were GM130 for cis-Golgi, TGN38 for the trans Golgi network, SNX2 for early endosomes, and Cathepsin D for secretory granule protease. A minimum of 8 images was analyzed for each colocalization assay.

\section{Transmission Electron Microscopy (TEM)}

Cells were plated $\left(4.5 \times 10^{4}\right.$ cells/well) in 6-well tissue culture plates (Corning Life Sciences) and cultured for 2 days before fixation. Media were changed daily before fixation. Cells were rinsed in PBS and fixed by microwave irradiation in $0.05 \%$ glutaraldehyde (Electron Microscopy Sciences) plus $4 \%$ formaldehyde (Electron Microscopy Sciences) in $0.1 \mathrm{M}$ cacodylate buffer (pH 7.4), containing $0.025 \% \mathrm{CaCl}_{2}$ for $10 \mathrm{~s}$, as previously described [33]. For pre-embedding immunoelectron microscopy cells were rinsed with $50 \mathrm{mM}$ glycine in PBS for $15 \mathrm{~min}$, and blocked for 45 min with 1\% BSA in PBS. Cells were then permeabilized with $0.05 \%$ saponin in PBS containing $1 \%$ BSA for $15 \mathrm{~min}$, incubated with anti- $\delta \mathrm{SA} 4$ for $2 \mathrm{~h}$ at RT, rinsed, and subsequently incubated with goat anti-mouse IgG conjugated to nanogold (Nanoprobes) for $1 \mathrm{~h}$ at RT. After rinsing in 3 times with PBS containing 1\% BSA with cells were fixed with 2.5\% glutaraldehyde in $0.1 \mathrm{M}$ cacodylate buffer for $1 \mathrm{~h}$, rinsed twice with $0.1 \mathrm{M}$ cacodylate buffer and 5 times with Milli-Q water. The nanogold was enhanced using GoldEnhance ${ }^{\mathrm{Tw}}$ Electron Microscopy Plus (Nanoprobes) for 6 min according to the manufacturer's directions. In all TEM experiments cells were post fixed in $1 \%$ reduced $\mathrm{OsO}_{4}$ (Electron Microscopy Sciences) [34] in $0.1 \mathrm{M}$ cacodylate buffer ( $\mathrm{pH}$ 7.4) for $2 \mathrm{~h}$, rinsed in Milli-Q water, and dehydrated in a graded ethanol series. Cells were removed from the tissue culture plates with propylene oxide and embedded in EMBED 812 (Electron Microscopy Sciences). Thin sections were cut with a diamond knife, mounted on copper grids, and stained for 10 min each in Reynolds's lead citrate (Reynolds 1963) and 0.5\% aqueous uranyl acetate, and examined with a JEOL JEM-100CXII (JEOL Ltd., Tokyo, Japan) transmission electron microscope. For morphometric analysis of mast cell secretory granules images of a minimum of 30 cells from each condition were analyzed using Image J software [31]. For area measurements, the secretory granules were manually selected with the freehand selection tool and the area measurements were calculated using the ROI manager tool. The selection criteria for the RBL-2H3 secretory granules were based on following morphological features: membrane limited organelles displaying internal membrane vesicles interspace with dense membranous material and electrontranslucent areas. Double membrane compartments were not selected to avoid confusion with mitochondria.

\section{Scanning Electron Microscopy (SEM)}

Cells were plated on $13 \mathrm{~mm}$ round coverslips $\left(5.0 \times 10^{4}\right.$ cells/coverslip) and sensitized or not with IgE anti-TNP ascites fluid in the culture medium and incubated for $16 \mathrm{~h}$ followed or not by stimulation with $50 \mathrm{ng} / \mathrm{mL}$ of $\mathrm{DNP}_{48}$-HSA (Sigma-Aldrich) for $15 \mathrm{~min}$. Cells were rinsed in warm PBS $\left(37^{\circ} \mathrm{C}\right)$ and fixed with $2 \%$ glutaraldehyde (Electron Microscopy Sciences) in warm $\mathrm{PBS}$ for $2 \mathrm{~h}$ at RT. Cells were post fixed in $1 \% \mathrm{OsO}_{4}$ (Electron Microscopy Sciences) for $2 \mathrm{~h}$, rinsed in Milli-Q water, incubated with a saturated solution of thiocarbohydrazide (Electron Microscopy Sciences), followed by $1 \% \mathrm{OsO}_{4}$. This step was repeated once. The cells were dehydrated in a graded series of ethanol and critically point-dried with liquid $\mathrm{CO}_{2}$ in a Tousimis Autosandri-810 (Tousimis Research Co., Rockville, MD), mounted on aluminum stubs with silver paint (Electron Microscopy Sciences), and coated with gold in a BAL-TEC SCD 050 Sputter Coater (BAL-TEC). Samples were examined with a JEOL JSM-6610 LV scanning electron microscope (JEOL, Ltd.; Tokyo, Japan). 


\section{$\beta$-hexosamidase assay}

Mast cell degranulation was assessed by measuring the activity of released $\beta$-hexosaminidase after FceRI stimulation. Cells were plated $\left(3.0 \times 10^{4}\right.$ cells/well $)$ in a 96 well tissue culture plate (Costar-Corning Inc.), sensitized or not with IgE anti-TNP ascites fluid in the culture medium and incubated for $16 \mathrm{~h}$ followed or not by stimulation with $50 \mathrm{ng} / \mathrm{mL}$ of $\mathrm{DNP}_{48}-\mathrm{HSA}$ (SigmaAldrich) for $45 \mathrm{~min}$. $\beta$-hexosaminidase release was determined as previously described [35]. $\beta$ hexosaminidase activity was quantified in the supernatants and cell lysates by spectrophotometric analysis of hydrolysis of 4-Nitrophenyl N-acetyl- $\beta$-D-glucosaminide (Sigma-Aldrich). $\beta$-hexosaminidase release was calculated as the percentage of $\beta$-hexosaminidase activity measured in the supernatants relative to the total amount of $\beta$-hexosaminidase activity measured in the supernatant and cells.

\section{Lipid mediator release assay}

Cells were plated $\left(1.0 \times 10^{5}\right.$ cells/well) in a 24 well tissue culture plate (Corning Life Sciences) sensitized or not with IgE anti-TNP ascites fluid (1:5000 dilution) in the culture medium and incubated for $16 \mathrm{~h}$ followed or not by stimulation with $50 \mathrm{ng} / \mathrm{mL}$ of $\mathrm{DNP}_{48}-\mathrm{HSA}$ (SigmaAldrich) for $30 \mathrm{~min}$. PGD2 and LTC4 in culture supernatants were analyzed using EIA kits (Cayman Chemical, Ann Arbor, MI).

\section{Cytokine release assay}

Cells were plated $\left(1.0 \times 10^{5}\right.$ cells/well) in a 24 well tissue culture plate (Corning Life Sciences) sensitized with IgE anti-TNP ascites fluid (1:5000 dilution) in the culture medium and incubated for $16 \mathrm{~h}$ followed by stimulation with $50 \mathrm{ng} / \mathrm{mL}$ of $\mathrm{DNP}_{48}-\mathrm{HSA}$ (Sigma-Aldrich) for $1 \mathrm{~h}$. Culture supernatants were discarded and the cells were washed and incubated with fresh media for an additional 23h. The supernatants were collected and released cytokines were analyzed using the Proteome Profiler Rat Cytokine Array Kit, Panel A (R\&D Systems, Inc. Minneapolis, MN) according to the manufacturer's instructions. Briefly, supernatants were mixed with a cocktail of biotinylated detection antibodies and then incubated with the membrane containing immobilized antibodies for 29 rat cytokines. Bound protein was detected with streptavidin conjugated to HRP. Membranes were washed and developed using $\mathrm{ECL}^{\mathrm{Tm}}$ Western Blotting Detection Reagent RPN2106 (GE Healthcare).

\section{Statistics}

Results were analyzed using GraphPad Prism (GraphPad Software, Inc., La Jolla, CA) and expressed as mean \pm SD. In the colocalization experiments, statistical differences were assessed by a two-tailed unpaired t test with Welch's correction. In all shRNA experiments differences between groups were assessed by one-way ANOVA with Dunnett's post-test and all groups were compared with the shRNA control group; A $p<0.05\left(^{*}\right)$ was considered significant.

\section{Results}

\section{The AP-3 complex is expressed in rat peritoneal mast cells}

Since the presence of AP-3 has not been previously reported in MCs, the expression of AP-3 in rat peritoneal mast cells was investigated by direct immunofluorescence. The peritoneal lavage from Wistar rats was immunostained with antibodies to the $\delta$ subunit of AP-3. In order to conclusively identify MCs, the peritoneal lavage was also immunostained for the MC specific gangliosides derived from GD1b. These rodent mast cell specific gangliosides are expressed in both immature and mature rat mast cells $[36,37]$. AP-3 displayed a punctate staining pattern 

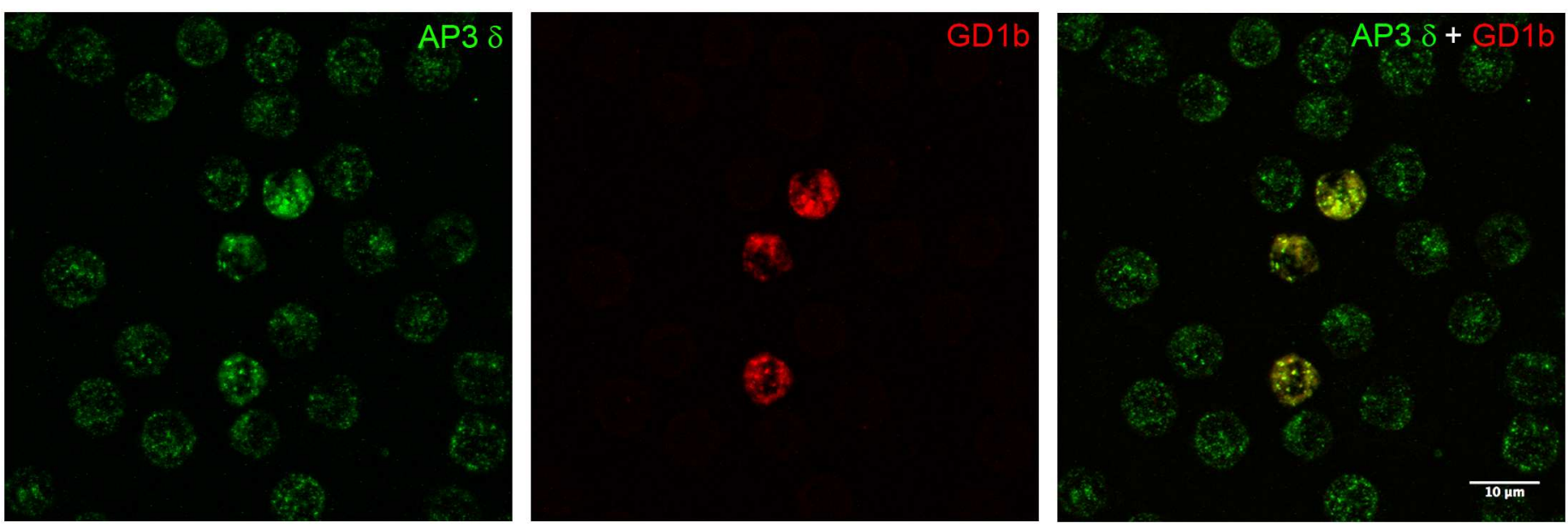

Fig 1. AP-3 is expressed in rat peritoneal mast cells. AP-3 was distributed in a punctate fashion in the cytoplasm of cells from the rat peritoneal lavage. Double labeling of the peritoneal lavage for AP-3 and the MC specific GD1b derived gangliosides revealed that the MCs were prominently stained for AP3. Anti-AP-3 $\delta$ antibody (mAb anti- $\delta S A 4$ ) was fluorescently labeled with the Zenon Alexa Fluor 488 (Green) and anti-MC specific GD1b derived gangliosides (mAb AA4) was fluorescently labeled with the Zenon Alexa Fluor 594 (Red). Bar $=10 \mu \mathrm{m}$.

doi:10.1371/journal.pone.0173462.g001

throughout the cytoplasm of all the cells in the peritoneal lavage. Furthermore, the MCs appeared to be more intensely stained (Fig 1), thus demonstrating that AP-3 is present in MCs exvivo.

\section{The AP-3 complex colocalizes with the biosynthetic and endocytic pathways in RBL-2H3 cells}

In order to facilitate the investigation of the role of AP- 3 in $\mathrm{MC}$ regulated secretion, the rat mast cell line RBL-2H3 was used in all further experiments. The subcellular localization of AP3 in these cells was analyzed by immunostaining with antibodies to the $\delta$ subunit of AP- 3 as well as markers for components of the secretory pathway (Fig 2A). AP-3 displayed a punctate staining pattern throughout the cytoplasm similar to that seen for peritoneal mast cells, and partially colocalized with markers for the cis-Golgi saccules, TGN, tubule-vesicular early endosomes and secretory granules. An analysis of the percentage of colocalization of AP-3 with the various markers showed that the colocalization was lowest in the cis-Golgi saccules but increased significantly in the TGN, early endosomes and secretory granules (Fig 2B).

By immunoelectron microscopy, AP-3 was found associated with the cytoplasmic face of vesicles and tubular structures in close proximity to the Golgi complex (Fig 3A and 3B). AP-3 was also associated with vesicles and tubular endosomal structures near the plasma membrane (Fig 3A and 3C). The association of AP-3 with the TGN and tubule-vesicular endosomes indicates that in MCs, AP-3 dependent sorting of proteins to secretory granules originates in these organelles.

\section{AP-3 $\delta$ knockdown destabilizes the AP-3 complex}

To assess a possible role for AP-3 in MC regulated exocytosis, the expression of AP-3 was knocked down in RBL-2H3 mast cells. RBL-2H3 cells were transduced with lentiviral particles encoding for two different shRNAs against the $\delta$ subunit of AP-3. Quantitative RT-PCR showed an approximately $80 \%$ decrease in AP- $3 \delta$ mRNA expression compared to cells expressing a nontargeting shRNA (Fig 4A). Flow cytometry analysis showed a $50 \%$ reduction in AP-3 $\delta$ protein levels compared to control cells (Fig 4B). Western blot analysis using an 
A
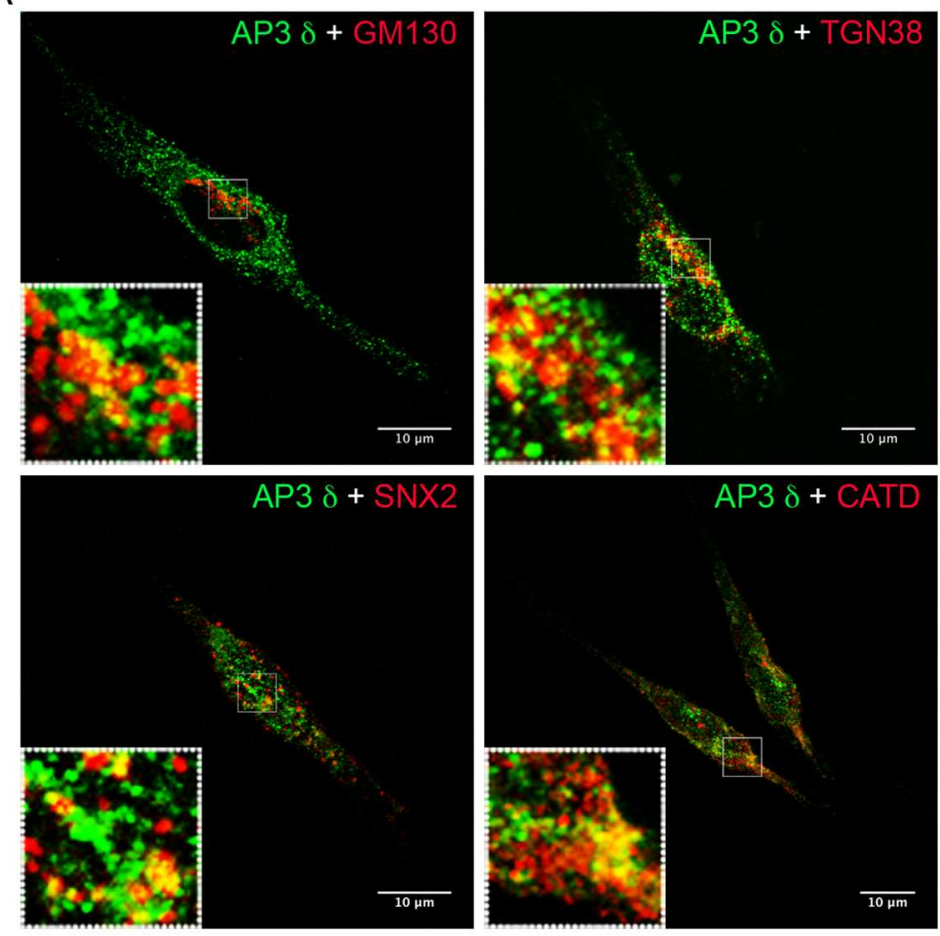

B

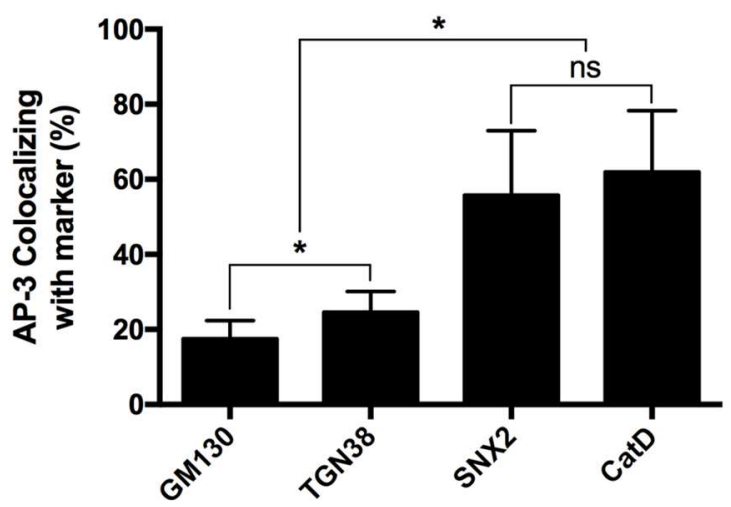

Fig 2. AP-3 colocalizes with markers of the biosynthetic and endocytic pathways. (A) AP-3 was distributed in a punctate fashion in the cytoplasm of the RBL-2H3 cells. Double labeling of AP-3 with antiGM130 (cis-Golgi), anti-TGN38 (TGN), anti-SNX2 (early endosomes) or anti-Cathepsin D (secretory granules) showed a partial colocalization. The rabbit polyclonal antibody anti-AP3D1 was used in the double staining of AP-3 with GM130 and TGN38 (upper panels) and the mouse mAb anti-סSA4 was used in the double staining of AP-3 with SNX2 and CATD (lower panels). Anti-AP-3 $\delta$ antibodies were detected with secondary antibodies conjugated with Alexa-488 (green); anti-GM130, anti-TGN38, anti-SNX2, and antiCATD were detected with secondary antibodies conjugated to Alexa 594 (red). Bar $=10 \mu \mathrm{m}$. (B) Manders' colocalization coefficient values are expressed as the percentage of AP-3 that colocalized with the organelle markers. Data is expressed as the mean \pm SD of colocalization analysis of at least eight individual images from a total of three independent experiments. ns: not significant; * $p \leq 0.05$.

doi:10.1371/journal.pone.0173462.g002

antibody specific to the $\mu 3$ subunit of AP-3 showed that AP- $3 \delta$ knockdown leads to an equivalent reduction (50\%) in $\mu 3$ levels confirming that the whole complex was destabilized (Fig 4C and 4D). Moreover, AP-3 $\delta$ knockdown did not affect the levels of AP- $1 \gamma$ expressed in MCs (Fig 4C). 

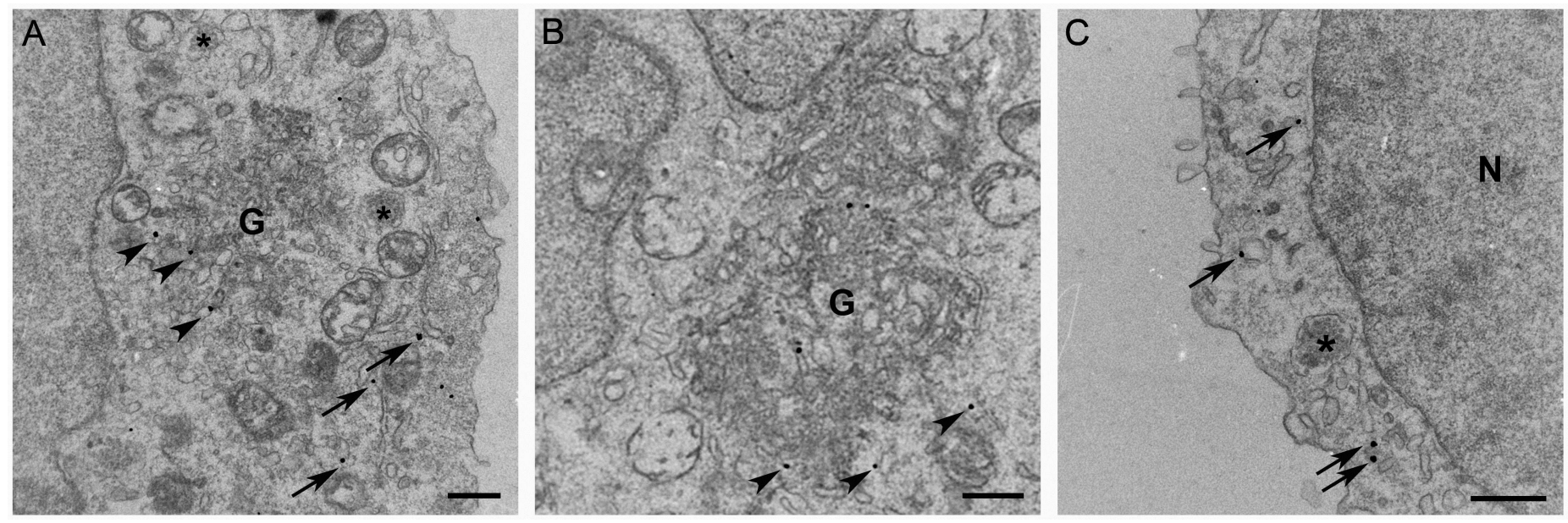

Fig 3. AP-3 is associated with membrane bound organelles in the biosynthetic and endocytic pathway. By immunoelectron microscopy, AP-3 was localized on cytoplasmic side of vesicles and tubular structures in close proximity to the Golgi complex (A and B) (arrowheads) and on tubule-vesicular endosomal membranes ( $A$ and $C$ ) adjacent to the plasma membrane (arrows). Bar $=0.5 \mu \mathrm{m}$. N: Nucleus; G: Golgi; *: Secretory Granule.

doi:10.1371/journal.pone.0173462.g003

\section{ShRNA mediated depletion of AP-3 adaptor complex did not interfere with FcERI expression or the morphological changes associated with MC activation}

FceRI mediated MC activation is the best characterized pathway of mast cell activation, which is crucial for the regulated secretion of MC mediators. Therefore, it was of interest to verify that shRNA mediated AP-3 knockdown did not interfere with key features of FceRI activation such as FceRI surface expression and activation induced membrane ruffling. Knockdown of AP-3 $\delta$ did not alter the expression of FceRI on the surface of RBL-2H3 cells, as detected by flow cytometry analysis (Fig 5A). Furthermore, shRNA mediated AP-3 knockdown did not affect the cell spreading and surface ruffling that are characteristic of mast cell activation (Fig 5B).

\section{The AP-3 complex is critical for regulated secretion of preformed mediators}

Although AP-3 knockdown did not interfere with FceRI expression or the morphological changes induced by activation via FceRI, it was of interest to determine if the secretion of preformed MC mediators was affected following FceRI stimulation. The 50\% reduction in AP-3 protein levels was sufficient to significantly affect MC regulated secretion of $\beta$-hexosaminidase (Fig 6A). Knockdown of the $\delta$ subunit of AP-3 caused an approximately $45 \%$ reduction in release of $\beta$-hexosaminidase activity, for both $\delta$ shRNAs tested, in comparison to RBL-2H3 cells transduced with control shRNA. Furthermore, this observed decrease was not a consequence of reduced cellular levels of $\beta$-hexosaminidase since the total enzyme activity in AP-3 depleted cells was not significantly different from the total enzyme activity present in control cells (Fig 6B). This result indicates that AP-3 plays a critical role in regulated exocytosis in MC.

\section{AP-3 knockdown leads to an enlargement of MC secretory granules}

Since AP-3 knockdown affected release of preformed mediators that are stored in secretory granules, it was of interest to evaluate secretory granule morphology. MC granules were 
A

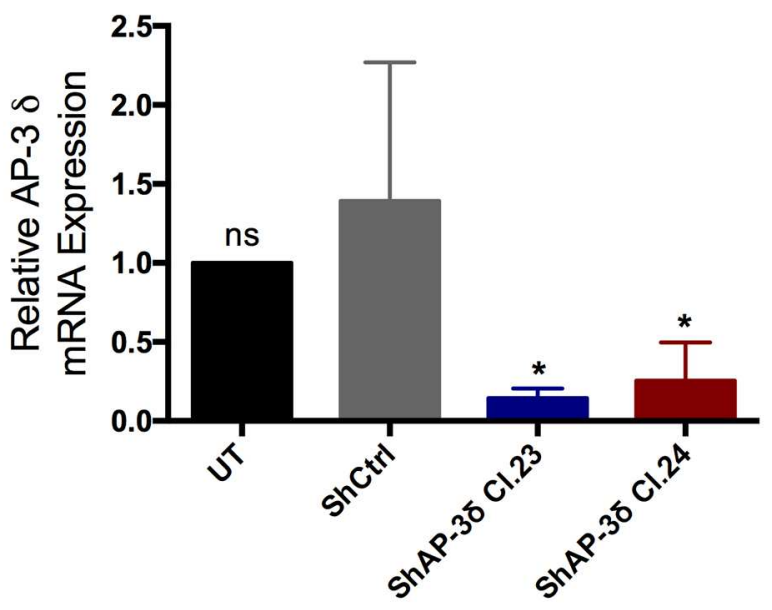

C

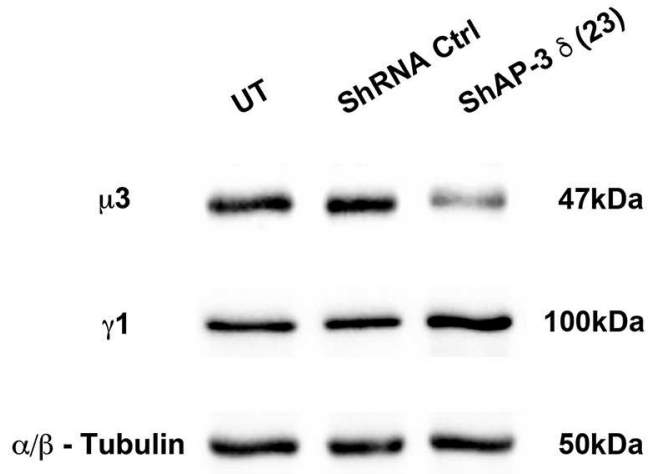

B
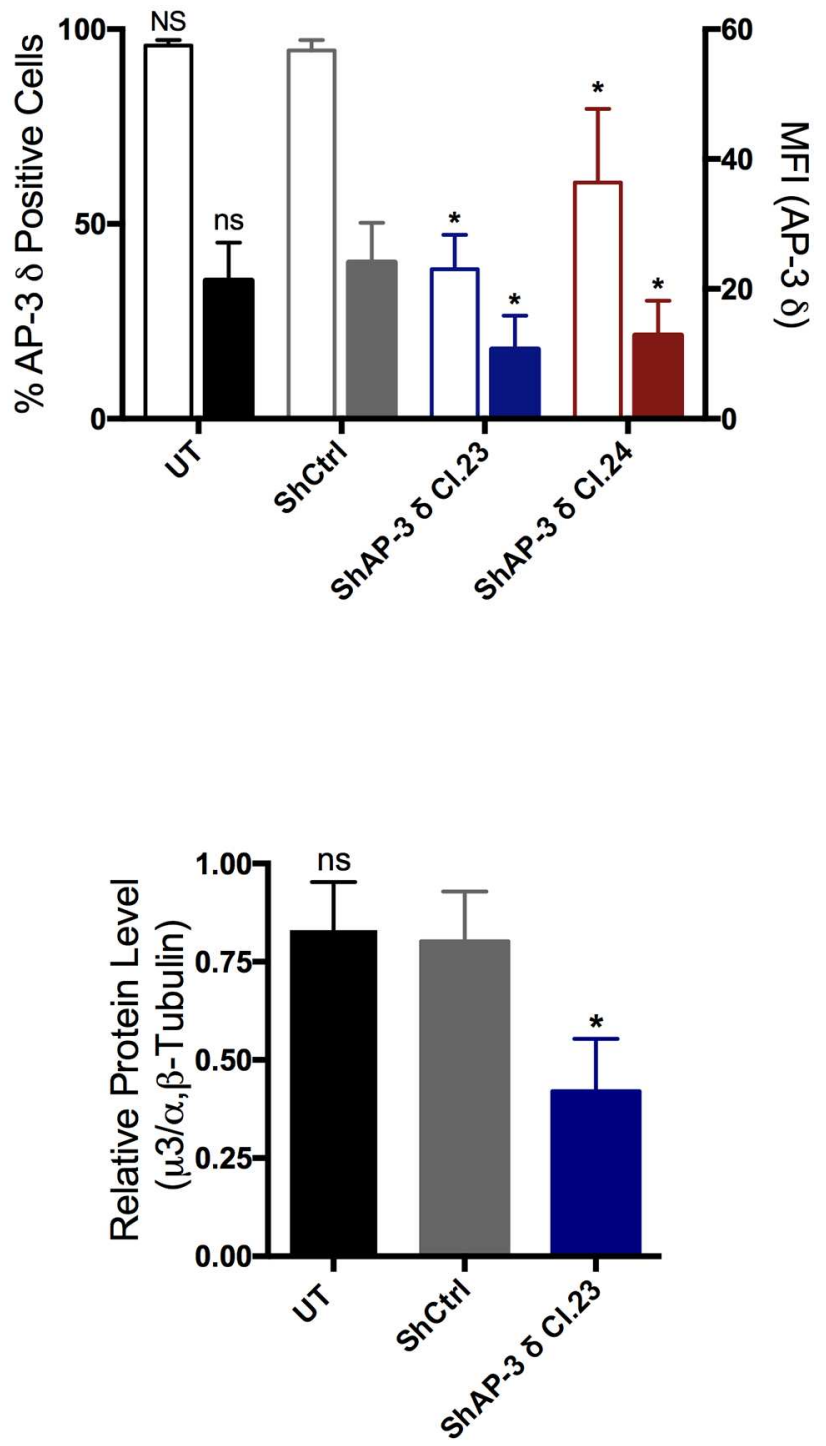

Fig 4. ShRNA mediated depletion of AP-3 $\delta$ subunit destabilizes the AP-3 adaptor complex in RBL-2H3 mast cells. RBL-2H3 cells were transduced with lentiviral particles expressing shRNAs against the $\delta$ subunit of the AP-3 complex (ShAP-3 $\delta$ Cl.23 and ShAP-3 $\delta$ Cl.24) or with nontargeting shRNA control (ShCtrl). (A) By quantitative RT-PCR, RBL-2H3 cells transduced with AP-3 $\delta$ shRNAs had an average reduction of $80 \%$ in AP$3 \delta$ mRNA expression when compared to shRNA control cells (ShCtrl). (B) By FACS analysis of permeabilized cells immunostained with anti- $\delta S A 4$ antibody, AP-3 $\delta$ protein levels were reduced by approximately $50 \%$ when compared to ShCtrl cells. Open Bars: \% of AP-3 $\delta$ positive cells; Colored Bars: Mean Fluorescence Intensity (MFI). (C) Western blot analysis showed that in RBL-2H3 cells knocked down for AP-3 $\delta$ there was a reduction in AP-3 $\mu 3$ expression while AP-1 y protein levels were unaltered. Representative Western blot images. (D) Ratio of AP- $3 \mu 3$ to $\alpha / \beta$ tubulin. The $50 \%$ reduction in AP-3 $\mu 3$ expression was equivalent to that seen for AP-3 $\delta$. The AP-3 $\mu 3$ subunit was immunolabeled with the mAb anti-p47A and the AP-1 $Y$ was labeled with the $\mathrm{mAb}$ anti-Adaptin $\mathrm{\gamma}$. Data is expressed as the mean $\pm \mathrm{SD}$ of at least three independent experiments. Statistical difference in comparison to shRNA control transduced cells (ShCtrl). ns: not significant; ${ }^{*}: p \leq 0.05 ;$ UT: untransduced cells.

doi:10.1371/journal.pone.0173462.g004

evaluated by electron microscopy in order to investigate the involvement of AP-3 in the biogenesis of secretory granules. In RBL-2H3 MCs secretory granules are membrane-limited organelles displaying internal membrane vesicles interspersed with electron dense and electron lucent areas. AP-3 knockdown did not interfere with the overall ultrastructure of the 
A

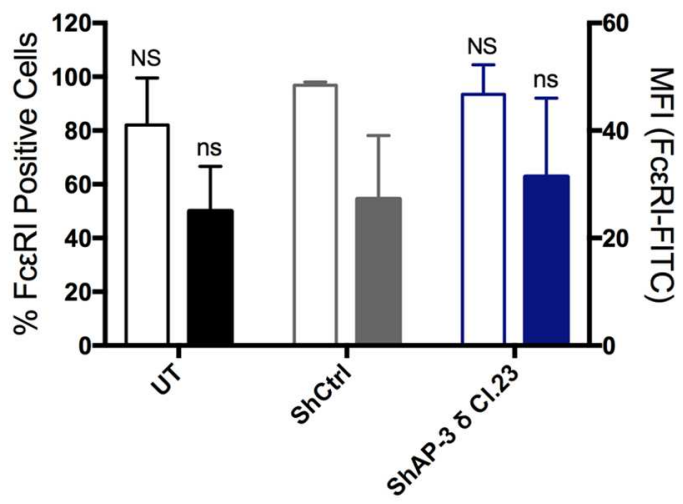

B
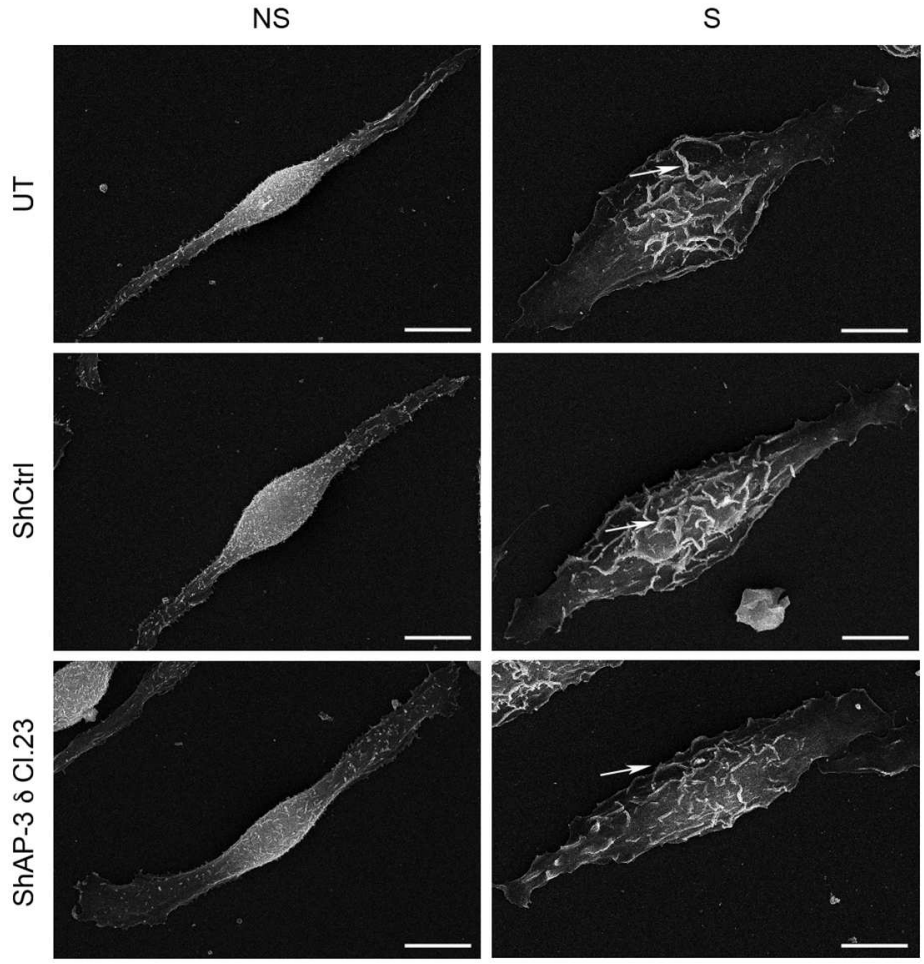

Fig 5. ShRNA mediated depletion of AP-3 does not interfere with FceRI surface expression or the morphological changes characteristic of MC activation. (A) By FACS analysis, there were no significant differences in expression of FcERI on the surface of RBL-2H3 cells transduced with AP- $3 \delta$ shRNA (ShAP- $3 \delta$ Cl.23) and shRNA control (ShCtrl) or untransduced cells (UT). Open Bars: \% of FcERI positive cells; Colored Bars: Mean Fluorescence Intensity (MFI). Data is expressed as the mean \pm SD of three independent experiments. Statistical differences are in comparison to shRNA control transduced cells (ShCtrl). ns: not significant. (B) By scanning electron microscopy AP-3 knockdown did not interfere with cell spreading or ruffling (arrows) of RBL-2H3 cells activated via FcERI. NS: non-stimulated; S: stimulated via FcERI.

doi:10.1371/journal.pone.0173462.g005

secretory granules in these cells or affect the average number of granules per cell. However, a significant increase in the area of the MC granules was observed in AP-3 knockdown MCs (Fig 7A-7C). This increase in granule area further indicates that AP-3 is involved in MC secretory granule biogenesis. 
A

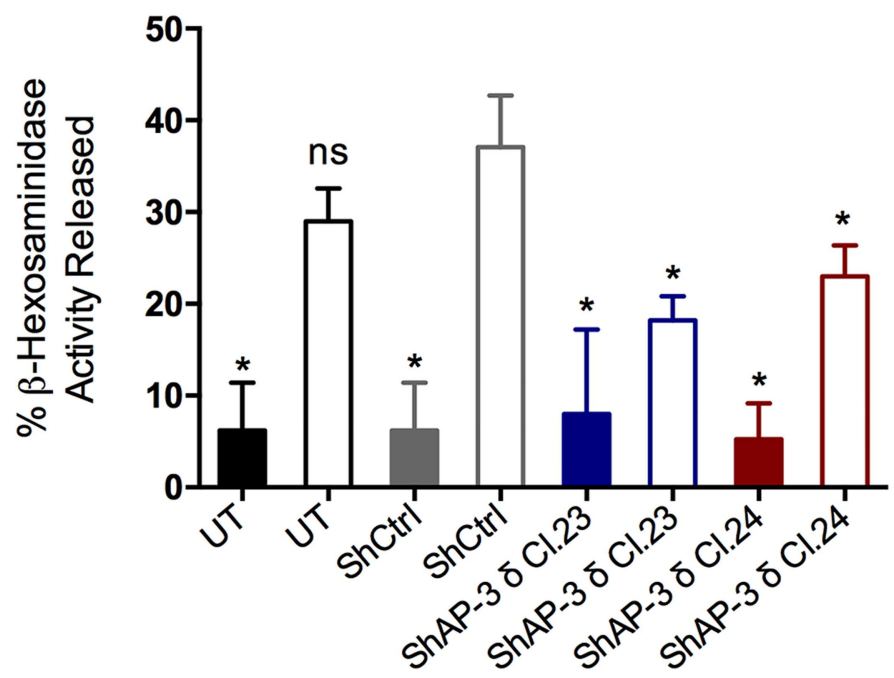

B

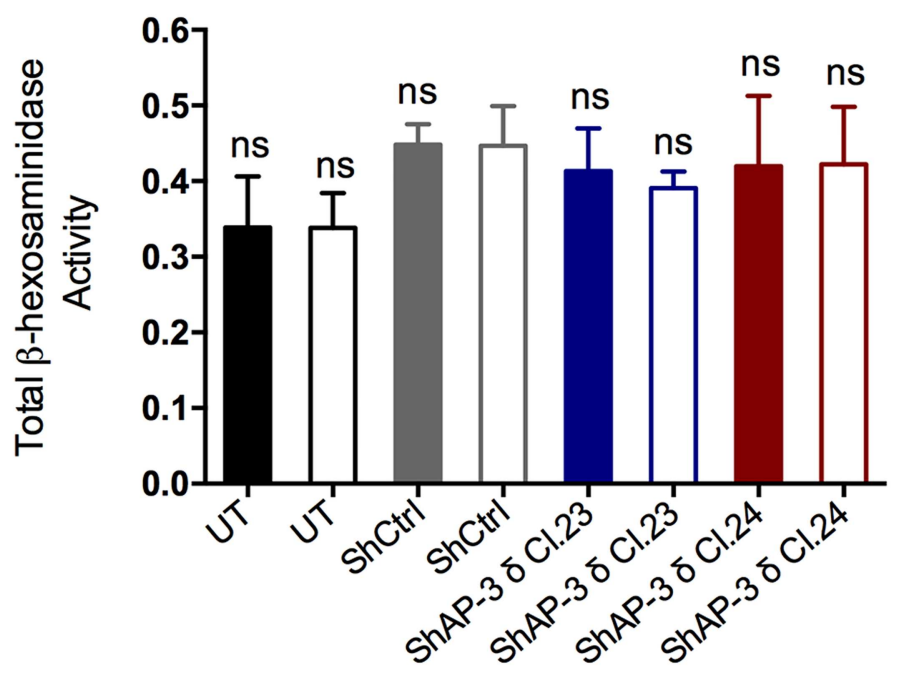

Fig 6. AP-3 knockdown resulted in decreased $\beta$-hexosaminidase release in FcعRI stimulated mast cells. For stimulation via FcERI, RBL-2H3 cells were sensitized with IgE anti-DNP and stimulated with $\mathrm{DNP}_{48^{-}}$ HSA ( $50 \mathrm{ng} / \mathrm{mL}$ ) for $45 \mathrm{~min}$. The activity of released and total $\beta$-hexosaminidase was determined for stimulated (Open Bars) and non-stimulated cells (Colored Bars). (A) FceRI stimulated RBL-2H3 cells transduced with AP-3 $\delta$ shRNAs (ShAP-3 $\delta \mathrm{Cl} .23$ and Cl.24) had an average $45 \%$ reduction in the release of $\beta$-hexosaminidase activity when compared to shRNA control cells (ShCtrl). (B) Total $\beta$-hexosaminidase activity levels were unaltered in AP-3 knockdown cells when compared to ShCtrl cells. Data is expressed as the mean \pm SD of three independent experiments. Statistical differences are in comparison to stimulated shRNA control transduced cells (ShCtrl). ns: not significant; * $p \leq 0.05$; UT: untransduced cells. Black Line Bars: UT; Gray Line Bars: ShCtrl; Blue Line Bars: ShAP-3ठ Cl.23; and Red Line Bars: ShAP-3ठ CI.24.

doi:10.1371/journal.pone.0173462.g006

\section{AP-3 knockdown influences newly formed mediator release}

In addition to the regulated release of preformed mediators, mast cell activation leads to the de novo synthesis of lipid mediators, such as prostaglandins and leukotrienes, which are 
A
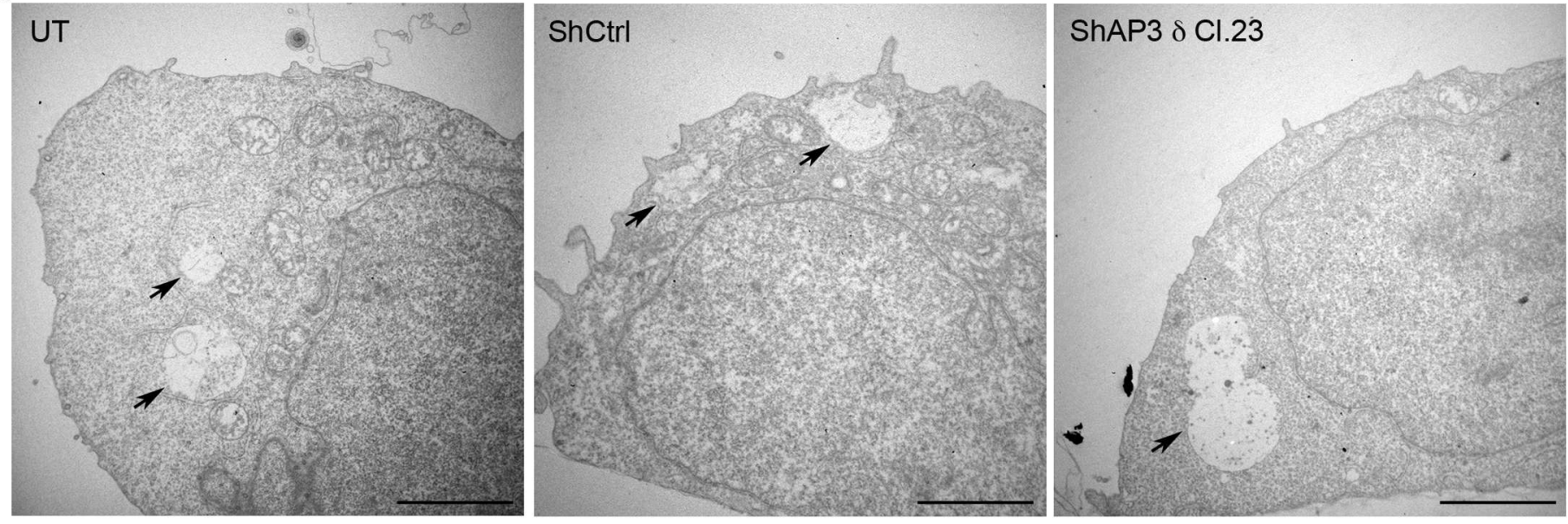

B

C
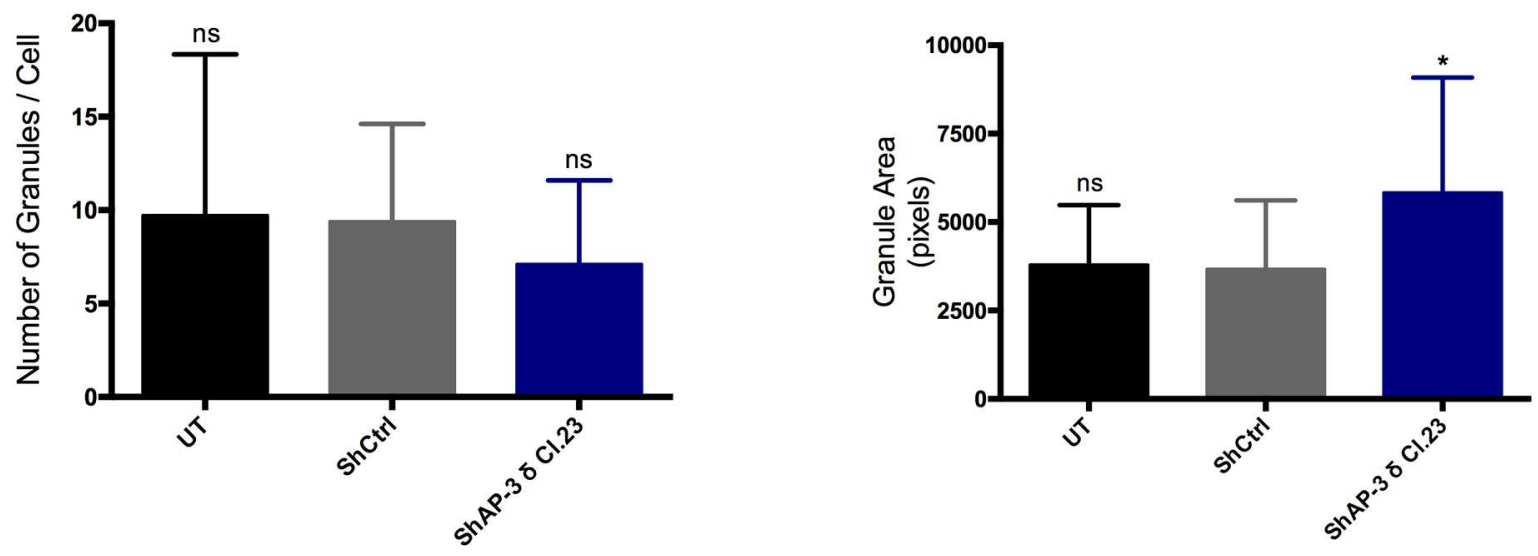

Fig 7. AP-3 knockdown leads to enlarged MC secretory granules. RBL-2H3 MCs were transduced or not with shRNAs and analyzed by transmission electron microscopy. (A) The area of the secretory granules was increased in the AP-3 knockdown cells (ShAP-3 $\delta$ Cl.23) when compared to shRNA control cells (ShCtrl). UT: untransduced cells; ShCtrl: shRNA control transduced cells; and ShAP-3 $\delta$ Cl.23: shRNA AP-3 $\delta$ Cl.23 transduced cells. The arrows indicate secretory granules. Bar $=5 \mu \mathrm{m}$. The graphs show the quantification of secretory granules numbers per cell (B) and granule area expressed in pixels $(C)$. Data is expressed as the mean \pm SD from the image analysis of at least 30 individual cells from a total of three independent experiments. shRNA AP-3 $\delta \mathrm{Cl} .23$ transduced cells were compared to shRNA control transduced cells (ShCtrl). ns: not significant; *: $p \leq 0.05$.

doi:10.1371/journal.pone.0173462.g007

immediately formed after MC activation. The functional impact of AP-3 knockdown on the secretion of newly formed mediators following FceRI stimulation was investigated. Release of the lipid mediator prostaglandin D2 (PGD2) was decreased after FceRI activation in AP-3 knockdown MCs (Fig 8A) while leukotriene C4 (LTC4) release was not altered (Fig 8B). Therefore, AP-3 knockdown selectively affects lipid mediator release.

\section{AP-3 knockdown affects release of newly synthesized mediators}

Mast cell activation stimulates the synthesis and release of newly synthesized mediators such as cytokines and growth factors. Cytokines and growth factors are transcriptionally upregulated after MC activation and released by constitutive secretion. To investigate release of newly synthesized mediators IgE sensitized MCs were stimulated and after 1h the culture 
A

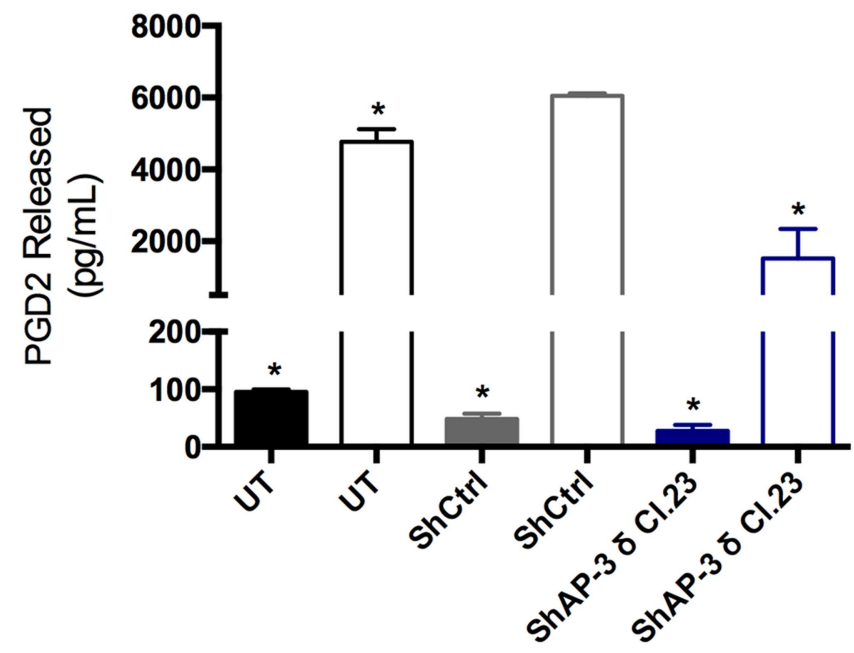

B

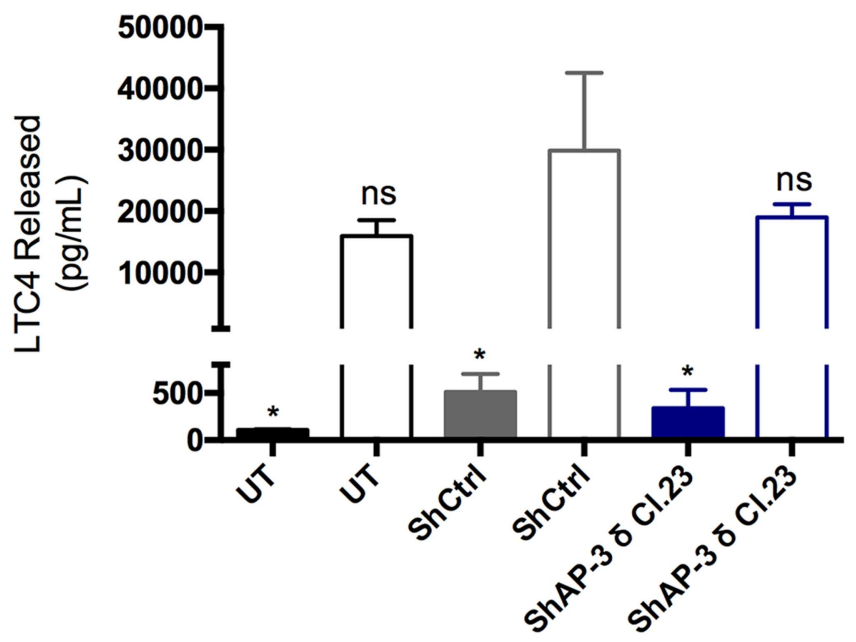

Fig 8. AP-3 knockdown affects newly formed mediator release. For stimulation via FcERI, RBL-2H3 cells were sensitized with $\lg E$ anti-TNP and stimulated with $\mathrm{DNP}_{48}-\mathrm{HSA}(50 \mathrm{ng} / \mathrm{mL})$. Lipid mediators were measured, 30 min after stimulation, in the culture supernatant by EIA. Prostaglandin D2 release $(A)$ was decreased in the AP-3 knockdown cells (ShAP-3 $\delta$ Cl.23) while release of leukotriene $\mathrm{C} 4(\mathrm{~B})$ was unaltered when compared to shRNA control cells (ShCtrl). Data is expressed as the mean \pm SD of two independent experiments. Statistical differences are in comparison to shRNA control transduced cells (ShCtrl). ns: not significant; *: $p \leq 0.05$; UT: untransduced cells.

doi:10.1371/journal.pone.0173462.g008

supernatants were discarded to exclude released preformed cytokines. After $23 \mathrm{~h}$ of incubation with fresh media the supernatants were analyzed using the Proteome Profiler Rat Cytokine Array Kit (Panel A) as described in Materials and Methods. Of the 29 cytokines analyzed 6 had their secretion significantly increased in AP-3 knockdown MCs when compared to ShCtrl cells (Table 1). The secretion of another 21 cytokines was also increased in AP-3 knockdown cells, although this increase was not significant. These results show the knockdown of AP-3 also influences the release of newly synthesized mediators. 
Table 1. AP-3 knockdown affects the release of newly synthesized mediators.

\begin{tabular}{|c|c|c|c|}
\hline \multirow[b]{2}{*}{ Cytokines } & \multicolumn{3}{|c|}{ MEAN PIXEL DENSITY \pm SD } \\
\hline & UT & ShCtrl & ShAP-3 ס Cl.23 \\
\hline CINC $-1 *$ & $1.44 \pm 0.17$ & $1.36 \pm 0.11$ & $3.10 \pm 0.45$ \\
\hline CINC-2 $\alpha / \beta^{*}$ & $0.60 \pm 0.27$ & $0.41 \pm 0.13$ & $1.88 \pm 0.36$ \\
\hline CINC-3* & $1.01 \pm 0.20$ & $1.00 \pm 0.14$ & $1.67 \pm 0.15$ \\
\hline CNTF & $1.03 \pm 0.34$ & $0.68 \pm 0.34$ & $1.37 \pm 0.35$ \\
\hline Fractalkine/CX3CL1 & $0.81 \pm 0.34$ & $0.68 \pm 0.25$ & $1.50 \pm 0.35$ \\
\hline GM-CSF* & $0.97 \pm 0.28$ & $0.73 \pm 0.09$ & $1.78 \pm 0.23$ \\
\hline sICAM-1/CD54 & $9.20 \pm 1.08$ & $9.48 \pm 2.84$ & $13.11 \pm 2.48$ \\
\hline IFN-Y* & $1.96 \pm 0.41$ & $0.85 \pm 0.12$ & $2.64 \pm 0.36$ \\
\hline IL-1a/IL-1F1 & $2.08 \pm 0.43$ & $1.87 \pm 0.26$ & $2.74 \pm 0.40$ \\
\hline IL-1ß/IL-1F2* & $1.20 \pm 0.23$ & $1.21 \pm 0.23$ & $2.28 \pm 0.15$ \\
\hline IL-1ra/IL-1F3 & $1.18 \pm 0.19$ & $1.05 \pm 0.17$ & $1.80 \pm 0.29$ \\
\hline IL-2 & $1.61 \pm 0.36$ & $1.39 \pm 0.45$ & $1.53 \pm 0.40$ \\
\hline IL-3 & $5.04 \pm 1.67$ & $3.97 \pm 0.65$ & $5.77 \pm 1.23$ \\
\hline IL-4 & $4.04 \pm 0.68$ & $4.27 \pm 0.83$ & $5.78 \pm 1.46$ \\
\hline IL-6 & $1.23 \pm 0.28$ & $0.52 \pm 0.15$ & $1.13 \pm 0.10$ \\
\hline IL10 & $1.48 \pm 0.29$ & $1.29 \pm 0.24$ & $1.71 \pm 0.13$ \\
\hline IL-13 & $30.73 \pm 14.07$ & $27.49 \pm 11.10$ & $35.35 \pm 14.38$ \\
\hline IL-17 & $2.44 \pm 0.67$ & $2.31 \pm 0.82$ & $3.25 \pm 0.53$ \\
\hline IP-10/CXCL10 & $1.23 \pm 0.21$ & $1.20 \pm 0.30$ & $1.71 \pm 0.34$ \\
\hline LIX & $1.92 \pm 0.34$ & $1.71 \pm 0.64$ & $1.51 \pm 0.53$ \\
\hline L-Selectin/CD62L & $2.21 \pm 0.27$ & $1.90 \pm 0.40$ & $2.20 \pm 0.33$ \\
\hline MIG/CXCL9 & $1.71 \pm 0.44$ & $1.38 \pm 0.41$ & $1.98 \pm 0.24$ \\
\hline MIP-1a/CCL3 & $1.29 \pm 0.40$ & $0.98 \pm 0.29$ & $1.29 \pm 0.19$ \\
\hline MIP-3a/CCL20 & $1.37 \pm 0.32$ & $1.39 \pm 0.10$ & $1.28 \pm 0.08$ \\
\hline RANTES/CCL5 & $2.55 \pm 0.21$ & $2.21 \pm 0.65$ & $2.87 \pm 0.24$ \\
\hline Thymus Chemokine/CXCL-7 & $44.44 \pm 5.55$ & $52.04 \pm 2.25$ & $61.18 \pm 8.25$ \\
\hline TIMP-1 & $1.31 \pm 0.18$ & $0.88 \pm 0.22$ & $1.41 \pm 0.26$ \\
\hline TNF- $\alpha$ & $1.20 \pm 0.07$ & $0.52 \pm 0.15$ & $0.74 \pm 0.20$ \\
\hline VEGF & $26.95 \pm 1.17$ & $27.69 \pm 4.16$ & $28.08 \pm 5.55$ \\
\hline
\end{tabular}

The Proteome Profiler ${ }^{\mathrm{TM}}$ - Rat Cytokine Array Panel A—was used to simultaneously assess the relative levels of 29 cytokines released in the supernatant of FcERI stimulated MCs. Data is expressed as the mean pixel density $\pm S D$ of three independent experiments. The mean pixel densities of spots for each cytokine in the membrane array were quantified using Image J. Cytokines whose secretion was significantly increased in AP-3 knockdown MCs are shaded in gray.

*: $p \leq 0.05$ in comparison to ShCtrl; UT: untransduced cells; ShCtrl: shRNA control transduced cells; and ShAP-3 $\delta$ Cl.23: shRNA AP-3 $\delta$ Cl.23 transduced cells.

doi:10.1371/journal.pone.0173462.t001

\section{Discussion}

The present investigation demonstrates, for the first time, that the AP-3 adaptor complex is present in rat MCs and that it is associated with both the biosynthetic and endocytic pathways of RBL-2H3 MCs. Additionally, AP-3 was shown to be important for MC regulated exocytosis of preformed mediators and to have a role in regulating $\mathrm{MC}$ secretory granule size. Furthermore, the reduced expression of AP-3 had an impact on the secretion of some newly formed and newly synthesized mediators. 
The present study shows an association of AP-3 with early endosomes as well as with the TGN. In spite of its recognized involvement in LRO biogenesis, the subcellular localization of AP-3 has long been a matter of debate. Several studies using immunofluorescence and immunogold labeling of AP-3 in different cell types have yielded conflicting results with respect to the localization of AP-3, suggesting a role for AP-3 in protein sorting either in the TGN or in endosomal compartments [38-43]. However, the association of AP-3 with one set of organelles does not exclude its involvement with another set. In the regulated secretory pathway, proteins destined for secretion are targeted to secretory granules either directly from the TGN or indirectly, via the endosomal system [6]. Both the biosynthetic and endocytic pathways were previously shown to be involved in LRO biogenesis in MCs. Some studies in MCs have demonstrated that the sorting of lysosomal proteases relies mainly on their glycosylation in the Golgi complex and subsequent targeting of these proteins by the mannose-6-phosphate receptor to MC secretory granules $[44,45]$. In contrast, other studies have demonstrated that internalized cargo can also be delivered to MC secretory granules $[46,47]$. The results of the present study provide evidence for a role of AP-3 in sorting and trafficking from both the TGN and endosomes in RBL-2H3 MCs.

Knockdown of AP-3 was used to functionally study AP-3 in RBL-2H3 MCs. ShRNA mediated knockdown of AP-3 $\delta$ subunit in MCs compromised the stability of the $\mu 3$ subunit indicating the AP-3 complex was destabilized. This observation is in agreement with previous studies showing that in the absence of one subunit the whole adaptor complex becomes unstable and the levels of the other subunits are diminished [48-51].

Morphometric analysis of RBL-2H3 secretory granules by electron microscopy showed that AP-3 knockdown caused a significant increase in the size of secretory granules, suggesting a role for AP-3 in RBL-2H3 MC secretory granule biogenesis. This finding agrees with previous studies that found a similar phenotype in AP-3 deficient neurons, neuroendocrine cells, cytotoxic $\mathrm{T}$ lymphocytes, and platelets [15, 18, 51-53]. One possible explanation for the increased granule size is that AP-3 is involved in secretory granule maturation. In RBL-2H3 MCs, knockdown of Synaptotagmin III (Syt III) leads to an increase in secretory granule size. The authors suggest that this is the result of deficiencies in the retrieval and recycling of granule proteins during granule maturation [54]. We analyzed the protein sequence of Syt III using the Eukaryotic Linear Motif database. This analysis indicated the presence of three tyrosine based motifs and one dileucine based motif in its cytosolic portion (data not shown), which could implicate AP-3 in Syt III sorting to the regulated secretory pathway. Further studies are necessary to confirm this hypothesis and to elucidate the mechanisms by which AP-3 acts in secretory granule biogenesis.

The present investigation indicates that AP-3 plays a role in regulated secretion in RBL2H3 MCs. After stimulation via FceRI, MCs deficient in AP-3 released significantly less of the preformed mediator $\beta$-hexosaminidase, although the total amount of $\beta$-hexosaminidase was the same as that present in the control cells. Additionally, the reduced release of $\beta$-hexosaminidase was not a consequence of changes in FceRI expression on the cell surface. The AP-3 knockdown RBL-2H3 cells also underwent morphological changes characteristic of FceRI activation. Our results are consistent with previous reports showing reduced secretion of lysosomal hydrolases by platelets from Pearl mice, which are deficient in the AP- $3 \beta 3 \mathrm{~A}$ subunit $[17,55,56]$. Some proteins, which are important for MC regulated secretion, were shown, in other cell types, to contain cytoplasmic sequences required for their correct sorting to secretory granules through an AP-3 dependent pathway [57-59]. SNARE proteins mediate membrane fusion and are crucial for exocytosis. In the plasma membrane, the SNAREs involved in MC degranulation are Syntaxin 4 and SNAP23, whereas in the granule membrane the SNAREs VAMP7 and VAMP8 facilitate membrane fusion [60, 61]. In other cell types, AP-3 was shown 
to interact with VAMP7 and target it to lysosomes and late endosomes [59]. Therefore, incorrect targeting of VAMP7 in AP-3 deficient MC could interfere with the granule's ability to fuse with the plasma membrane and release its contents.

AP- 3 can also influence the secretion of newly formed mediators. AP-3 deficient RBL-2H3 MCs released less PGD2, but release of LTC4 was unaltered. PGD2 and LTC4 are the main $\mathrm{MC}$ eicosanoids produced upon stimulation. Following FceRI activation, $\mathrm{CPLA}_{2}$ is translocated to membranes of intracellular compartments such as the endoplasmic reticulum, nuclear envelope, phagosomal membranes, and to lipid bodies where it liberates arachidonic acid (AA). Distinct metabolic pathways, involving different sets enzymes, are activated to sequentially convert AA to prostaglandins or leukotrienes [62, 63]. Activation of different signaling pathways in MCs can lead to differential release of specific mediators. When MCs are activated by crosslinking GD1b derived gangliosides on their surface, the release of prostaglandins is stimulated, but not leukotrienes [64]. In spite of the fact that lipid mediators do not rely on vesicular traffic to be secreted, compartmentalized synthesis depends on the translocation and assembly of specific enzymatic complexes necessary for the synthesis of a particular mediator [65]. Moreover, the release of the negatively charged lipid mediators to the extracellular environment relies on organic anion transporters of the ATP-binding cassette type III family, known as MRPs (multidrug-resistant related proteins) and SLCs (soluble carrier super family) [66-69]. This dependence on a membrane localized anionic transporter may account for differences in the release of specific mediators. Our data suggest that AP-3 indirectly influences PGD2 secretion by interfering with either synthesis or transporter mediated secretion.

AP-3 deficiency also resulted in increased secretion of several newly synthesized cytokines, which are transcriptionally upregulated after MC activation. In contrast to lipid mediators, cytokines are synthesized in the endoplasmic reticulum and travel through the secretory pathway by means of vesicular transport and are presumably released by constitutive secretion [27, 70]. The molecular mechanisms involved in cytokine secretion are still greatly unexplored and further investigation is necessary to clarify how AP-3 influences neosynthesized mediator release.

Taken together the results of the present study show that AP-3 activity is key to secretion of RBL-2H3 MC mediators, particularly for the biogenesis and regulated release of preformed mediators. In spite of significant advances in the knowledge of MC biology, the understanding of how MC mediators are selectively sorted and released from distinct secretory pathways and the proteins involved are largely unknown. The current investigation provides evidence of the participation and importance of AP-3 for these processes in rat mast cells.

\section{Acknowledgments}

The authors thank Elizabete Rosa Milani for assistance with the confocal microscopy and Maria Dolores Seabra Ferreira, Maria Teresa Picinoto Maglia and Jose Augusto Maulin for assistance with the electron microscopy, all from the Department of Cell and Molecular Biology and Pathogenic Bioagents, FMRP-USP, Ribeirao Preto, SP.

\section{Author Contributions}

Conceptualization: EZMS LLPS MCJ CO.

Formal analysis: EZMS.

Funding acquisition: EZMS EGFF DAS LLPS MCJ CO.

Investigation: EZMS EGFF DAS MCJ. 
Methodology: EZMS EGFF DAS MCJ CO.

Project administration: EZMS CO.

Resources: LLPS MCJ CO.

Supervision: MCJ CO.

Validation: EZMS EGFF DAS.

Visualization: EZMS MCJ CO.

Writing - original draft: EZMS.

Writing - review \& editing: EZMS MCJ CO.

\section{References}

1. Marks MS, Heijnen HF, Raposo G. Lysosome-related organelles: unusual compartments become mainstream. Curr Opin Cell Biol. 2013; 25(4):495-505. doi: 10.1016/j.ceb.2013.04.008 PMID: 23726022

2. Stinchcombe J, Bossi G, Griffiths GM. Linking albinism and immunity: the secrets of secretory lysosomes. Science. 2004; 305(5680):55-9. doi: 10.1126/science.1095291 PMID: 15232098

3. Luzio JP, Hackmann Y, Dieckmann NM, Griffiths GM. The biogenesis of lysosomes and lysosomerelated organelles. Cold Spring Harb Perspect Biol. 2014; 6(9):a016840. doi: 10.1101/cshperspect. a016840 PMID: 25183830

4. Saftig P, Klumperman J. Lysosome biogenesis and lysosomal membrane proteins: trafficking meets function. Nat Rev Mol Cell Biol. 2009; 10(9):623-35. doi: 10.1038/nrm2745 PMID: 19672277

5. Blott EJ, Griffiths GM. Secretory lysosomes. Nat Rev Mol Cell Biol. 2002; 3(2):122-31. doi: 10.1038/ nrm732 PMID: 11836514

6. Traub LM, Kornfeld S. The trans-Golgi network: a late secretory sorting station. Curr Opin Cell Biol. 1997; 9(4):527-33. PMID: 9261049

7. Bonifacino JS. Insights into the biogenesis of lysosome-related organelles from the study of the Hermansky-Pudlak syndrome. Ann N Y Acad Sci. 2004; 1038:103-14. doi: 10.1196/annals.1315.018 PMID: 15838104

8. Robinson MS. Adaptable adaptors for coated vesicles. Trends Cell Biol. 2004; 14(4):167-74. doi: 10. 1016/j.tcb.2004.02.002 PMID: 15066634

9. Bonifacino JS, Glick BS. The mechanisms of vesicle budding and fusion. Cell. 2004; 116(2):153-66. PMID: 14744428

10. Bonifacino JS, Traub LM. Signals for sorting of transmembrane proteins to endosomes and lysosomes. Annu Rev Biochem. 2003; 72:395-447. doi: 10.1146/annurev.biochem.72.121801.161800 PMID: 12651740

11. Ihrke G, Kyttälä A, Russell MR, Rous BA, Luzio JP. Differential use of two AP-3-mediated pathways by lysosomal membrane proteins. Traffic. 2004; 5(12):946-62. doi: 10.1111/j.1600-0854.2004.00236.X PMID: 15522097

12. Nakatsu $\mathrm{F}$, Ohno H. Adaptor protein complexes as the key regulators of protein sorting in the post-Golgi network. Cell Struct Funct. 2003; 28(5):419-29. PMID: 14745134

13. Dell'Angelica EC, Shotelersuk V, Aguilar RC, Gahl WA, Bonifacino JS. Altered trafficking of lysosomal proteins in Hermansky-Pudlak syndrome due to mutations in the beta $3 \mathrm{~A}$ subunit of the AP-3 adaptor. Mol Cell. 1999; 3(1):11-21. PMID: 10024875

14. Starcevic M, Nazarian R, Dell'Angelica EC. The molecular machinery for the biogenesis of lysosomerelated organelles: lessons from Hermansky-Pudlak syndrome. Semin Cell Dev Biol. 2002; 13(4):2718. PMID: 12243726

15. Clark RH, Stinchcombe JC, Day A, Blott E, Booth S, Bossi G, et al. Adaptor protein 3-dependent microtubule-mediated movement of lytic granules to the immunological synapse. Nat Immunol. 2003; 4 (11):1111-20. doi: 10.1038/ni1000 PMID: 14566336

16. Fontana S, Parolini S, Vermi W, Booth S, Gallo F, Donini M, et al. Innate immunity defects in Hermansky-Pudlak type 2 syndrome. Blood. 2006; 107(12):4857-64. doi: 10.1182/blood-2005-11-4398 PMID: 16507770 
17. Feng L, Novak EK, Hartnell LM, Bonifacino JS, Collinson LM, Swank RT. The Hermansky-Pudlak syndrome 1 (HPS1) and HPS2 genes independently contribute to the production and function of platelet dense granules, melanosomes, and lysosomes. Blood. 2002; 99(5):1651-8. PMID: 11861280

18. Enders A, Zieger B, Schwarz K, Yoshimi A, Speckmann C, Knoepfle EM, et al. Lethal hemophagocytic lymphohistiocytosis in Hermansky-Pudlak syndrome type II. Blood. 2006; 108(1):81-7. doi: 10.1182/ blood-2005-11-4413 PMID: 16551969

19. Artuc M, Hermes B, Steckelings U, Grützkau A, Henz B. Mast cells and their mediators in cutaneous wound healing —active participants or innocent bystanders? Exp Dermatol. 1999; 8(1):1-16. PMID: 10206716

20. Henz B. Exploring the mast cell enigma: a personal reflection of what remains to be done. Experimental Dermatology. 2008; 17(2):91-9. doi: 10.1111/j.1600-0625.2007.00658.x PMID: 18205712

21. Metcalfe D, Baram D, Mekori Y. Mast cells. Physiological Reviews. 1997; 77(4):1033-79. PMID: 9354811

22. Hiromatsu Y, Toda S. Mast cells and angiogenesis. Microsc Res Tech. 2003; 60(1):64-9. doi: 10.1002/ jemt.10244 PMID: 12500262

23. Abraham SN, St John AL. Mast cell-orchestrated immunity to pathogens. Nat Rev Immunol. 2010; 10 (6):440-52. doi: 10.1038/nri2782 PMID: 20498670

24. da Silva EZ, Jamur MC, Oliver C. Mast Cell Function: A New Vision of an Old Cell. J Histochem Cytochem. 2014.

25. Tsai M, Grimbaldeston M, Galli SJ. Mast cells and immunoregulation/immunomodulation. Adv Exp Med Biol. 2011; 716:186-211. doi: 10.1007/978-1-4419-9533-9_11 PMID: 21713658

26. Galli S, Lantz C. Allergy. In: Immunology. F, editor. Paul WE. Philadelphia: Lippincott-Raven Press; 1999. p. 1137-84.

27. Moon TC, Befus AD, Kulka M. Mast cell mediators: their differential release and the secretory pathways involved. Front Immunol. 2014; 5:569. doi: 10.3389/fimmu.2014.00569 PMID: 25452755

28. Barsumian $E$, Isersky $C$, Petrino $M$, Siraganian $R$. IgE-induced histamine-release from rat basophilic leukaemia-cell lines-Isolation of releasing and non-releasing clones. European Journal of Immunology. 1981:317-23. doi: 10.1002/eji.1830110410 PMID: 6166481

29. DuBridge RB, Tang P, Hsia HC, Leong PM, Miller JH, Calos MP. Analysis of mutation in human cells by using an Epstein-Barr virus shuttle system. Mol Cell Biol. 1987; 7(1):379-87. PMID: 3031469

30. Haft CR, de la Luz Sierra M, Barr VA, Haft DH, Taylor SI. Identification of a family of sorting nexin molecules and characterization of their association with receptors. Mol Cell Biol. 1998; 18(12):7278-87. PMID: 9819414

31. Schneider CA, Rasband WS, Eliceiri KW. NIH Image to ImageJ: 25 years of image analysis. Nat Methods. 2012; 9(7):671-5. PMID: 22930834

32. Li J, Peters PJ, Bai M, Dai J, Bos E, Kirchhausen T, et al. An ACAP1-containing clathrin coat complex for endocytic recycling. J Cell Biol. 2007; 178(3):453-64. doi: 10.1083/jcb.200608033 PMID: 17664335

33. Oliver C, Jamur MC. Fixation and embedding. Methods Mol Biol. 2010; 588:353-62. doi: 10.1007/9781-59745-324-0_37 PMID: 20012848

34. Karnovsky M, editor Use of ferrocyanide-reduced osmium tetroxide in electron microscopy. Eleventh Annual Meeting of the American Society for Cell Biology; 1971; New Orleans, LA: J Cell Biol.

35. Silveira e Souza A, Mazucato V, de Castro R, Matioli F, Ciancaglini P, de Paiva Paulino T, et al. The alpha-galactosyl derivatives of ganglioside $\mathrm{GD}(1 \mathrm{~b})$ are essential for the organization of lipid rafts in RBL-2H3 mast cells. Exp Cell Res. 2008; 314(13):2515-28. doi: 10.1016/j.yexcr.2008.05.014 PMID: 18585706

36. Jamur M, Grodzki A, Berenstein E, Hamawy M, Siraganian R, Oliver C. Identification and characterization of undifferentiated mast cells in mouse bone marrow. Blood. 2005; 105(11):4282-9. doi: 10.1182/ blood-2004-02-0756 PMID: 15718418

37. Oliver C, Sahara N, Kitani S, Robbins AR, Mertz LM, Siraganian RP. Binding of monoclonal antibody AA4 to gangliosides on rat basophilic leukemia cells produces changes similar to those seen with Fc epsilon receptor activation. J Cell Biol. 1992; 116(3):635-46. PMID: 1370498

38. Simpson F, Bright NA, West MA, Newman LS, Darnell RB, Robinson MS. A novel adaptor-related protein complex. J Cell Biol. 1996; 133(4):749-60. PMID: 8666661

39. Simpson F, Peden AA, Christopoulou L, Robinson MS. Characterization of the adaptor-related protein complex, AP-3. J Cell Biol. 1997; 137(4):835-45. PMID: 9151686

40. Dell'Angelica EC, Ohno H, Ooi CE, Rabinovich E, Roche KW, Bonifacino JS. AP-3: an adaptor-like protein complex with ubiquitous expression. EMBO J. 1997; 16(5):917-28. doi: 10.1093/emboj/16.5.917 PMID: 9118953 
41. Peden AA, Oorschot V, Hesser BA, Austin CD, Scheller RH, Klumperman J. Localization of the AP-3 adaptor complex defines a novel endosomal exit site for lysosomal membrane proteins. J Cell Biol. 2004; 164(7):1065-76. doi: 10.1083/jcb.200311064 PMID: 15051738

42. Asensio CS, Sirkis DW, Maas JW, Egami K, To TL, Brodsky FM, et al. Self-assembly of VPS41 promotes sorting required for biogenesis of the regulated secretory pathway. Dev Cell. 2013; 27(4):42537. doi: 10.1016/j.devcel.2013.10.007 PMID: 24210660

43. Theos AC, Tenza D, Martina JA, Hurbain I, Peden AA, Sviderskaya EV, et al. Functions of adaptor protein (AP)-3 and AP-1 in tyrosinase sorting from endosomes to melanosomes. Mol Biol Cell. 2005; 16 (11):5356-72. doi: 10.1091/mbc.E05-07-0626 PMID: 16162817

44. Dragonetti A, Baldassarre $M$, Castino R, Démoz M, Luini A, Buccione R, et al. The lysosomal protease cathepsin $\mathrm{D}$ is efficiently sorted to and secreted from regulated secretory compartments in the rat basophilic/mast cell line RBL. J Cell Sci. 2000; 113 (Pt 18):3289-98.

45. Olszewski MB, Trzaska D, Knol EF, Adamczewska V, Dastych J. Efficient sorting of TNF-alpha to rodent mast cell granules is dependent on N-linked glycosylation. Eur J Immunol. 2006; 36(4):9971008. doi: 10.1002/eji.200535323 PMID: 16541468

46. Raposo G, Tenza D, Mecheri S, Peronet R, Bonnerot C, Desaymard C. Accumulation of major histocompatibility complex class II molecules in mast cell secretory granules and their release upon degranulation. Mol Biol Cell. 1997; 8(12):2631-45. PMID: 9398681

47. Bonifacino JS, Yuan L, Sandoval IV. Internalization and recycling to serotonin-containing granules of the $80 \mathrm{~K}$ integral membrane protein exposed on the surface of secreting rat basophilic leukaemia cells. $J$ Cell Sci. 1989; 92 (Pt 4):701-12.

48. Kantheti P, Qiao X, Diaz ME, Peden AA, Meyer GE, Carskadon SL, et al. Mutation in AP-3 delta in the mocha mouse links endosomal transport to storage deficiency in platelets, melanosomes, and synaptic vesicles. Neuron. 1998; 21(1):111-22. PMID: 9697856

49. Peden AA, Rudge RE, Lui WW, Robinson MS. Assembly and function of AP-3 complexes in cells expressing mutant subunits. J Cell Biol. 2002; 156(2):327-36. doi: 10.1083/jcb.200107140 PMID: 11807095

50. Meyer C, Zizioli D, Lausmann S, Eskelinen EL, Hamann J, Saftig P, et al. mu1A-adaptin-deficient mice: lethality, loss of AP-1 binding and rerouting of mannose 6-phosphate receptors. EMBO J. 2000; 19 (10):2193-203. doi: 10.1093/emboj/19.10.2193 PMID: 10811610

51. Asensio CS, Sirkis DW, Edwards RH. RNAi screen identifies a role for adaptor protein AP-3 in sorting to the regulated secretory pathway. J Cell Biol. 2010; 191(6):1173-87. doi: 10.1083/jcb.201006131 PMID: 21149569

52. Grabner CP, Price SD, Lysakowski A, Cahill AL, Fox AP. Regulation of large dense-core vesicle volume and neurotransmitter content mediated by adaptor protein 3. Proc Natl Acad Sci U S A. 2006; 103 (26):10035-40. doi: 10.1073/pnas.0509844103 PMID: 16788073

53. Newell-Litwa K, Chintala S, Jenkins S, Pare JF, McGaha L, Smith Y, et al. Hermansky-Pudlak protein complexes, AP-3 and BLOC-1, differentially regulate presynaptic composition in the striatum and hippocampus. J Neurosci. 2010; 30(3):820-31. doi: 10.1523/JNEUROSCI.3400-09.2010 PMID: 20089890

54. Grimberg E, Peng Z, Hammel I, Sagi-Eisenberg R. Synaptotagmin III is a critical factor for the formation of the perinuclear endocytic recycling compartment and determination of secretory granules size. $\mathrm{J}$ Cell Sci. 2003; 116(Pt 1):145-54. PMID: 12456724

55. Meng R, Wu J, Harper DC, Wang Y, Kowalska MA, Abrams CS, et al. Defective release of a granule and lysosome contents from platelets in mouse Hermansky-Pudlak syndrome models. Blood. 2015; 125(10):1623-32. doi: 10.1182/blood-2014-07-586727 PMID: 25477496

56. Novak EK, Hui SW, Swank RT. Platelet storage pool deficiency in mouse pigment mutations associated with seven distinct genetic loci. Blood. 1984; 63(3):536-44. PMID: 6696991

57. Kent HM, Evans PR, Schäfer IB, Gray SR, Sanderson CM, Luzio JP, et al. Structural basis of the intracellular sorting of the SNARE VAMP7 by the AP3 adaptor complex. Dev Cell. 2012; 22(5):979-88. doi: 10.1016/j.devcel.2012.01.018 PMID: 22521722

58. Rous BA, Reaves BJ, Ihrke G, Briggs JA, Gray SR, Stephens DJ, et al. Role of adaptor complex AP-3 in targeting wild-type and mutated CD63 to lysosomes. Mol Biol Cell. 2002; 13(3):1071-82. doi: 10. 1091/mbc.01-08-0409 PMID: 11907283

59. Martinez-Arca S, Rudge R, Vacca M, Raposo G, Camonis J, Proux-Gillardeaux V, et al. A dual mechanism controlling the localization and function of exocytic v-SNAREs. Proc Natl Acad Sci U S A. 2003; 100(15):9011-6. doi: 10.1073/pnas.1431910100 PMID: 12853575

60. Woska JR, Gillespie ME. Small-interfering RNA-mediated identification and regulation of the ternary SNARE complex mediating RBL-2H3 mast cell degranulation. Scand J Immunol. 2011; 73(1):8-17. doi: 10.1111/j.1365-3083.2010.02471.x PMID: 21128998 
61. Woska JR, Gillespie ME. SNARE complex-mediated degranulation in mast cells. J Cell Mol Med. 2011.

62. Boyce JA. Eicosanoid mediators of mast cells: receptors, regulation of synthesis, and pathobiologic implications. Chem Immunol Allergy. 2005; 87:59-79. doi: 10.1159/000087571 PMID: 16107763

63. Boyce JA. Mast cells and eicosanoid mediators: a system of reciprocal paracrine and autocrine regulation. Immunol Rev. 2007; 217:168-85. doi: 10.1111/j.1600-065X.2007.00512.x PMID: 17498059

64. Filho EGF, da Silva EZM, Zanotto CZ, Oliver C, Jamur MC. Cross-Linking Mast Cell Specific Gangliosides Stimulates the Release of Newly Formed Lipid Mediators and Newly Synthesized Cytokines. Mediators Inflamm. 2016; 2016:9160540. doi: 10.1155/2016/9160540 PMID: 27578923

65. Bozza PT, Bakker-Abreu I, Navarro-Xavier RA, Bandeira-Melo C. Lipid body function in eicosanoid synthesis: an update. Prostaglandins Leukot Essent Fatty Acids. 2011; 85(5):205-13. doi: 10.1016/j.plefa. 2011.04.020 PMID: 21565480

66. Jedlitschky G, Keppler D. Transport of leukotriene C4 and structurally related conjugates. Vitam Horm. 2002; 64:153-84. PMID: 11898391

67. Reid G, Wielinga P, Zelcer N, De Haas M, Van Deemter L, Wijnholds J, et al. Characterization of the transport of nucleoside analog drugs by the human multidrug resistance proteins MRP4 and MRP5. Mol Pharmacol. 2003; 63(5):1094-103. PMID: 12695538

68. Rius M, Hummel-Eisenbeiss J, Keppler D. ATP-dependent transport of leukotrienes B4 and C4 by the multidrug resistance protein ABCC4 (MRP4). J Pharmacol Exp Ther. 2008; 324(1):86-94. doi: 10.1124/ jpet.107.131342 PMID: 17959747

69. Shirasaka Y, Shichiri M, Kasai T, Ohno Y, Nakanishi T, Hayashi K, et al. A role of prostaglandin transporter in regulating $\mathrm{PGE}_{2}$ release from human bronchial epithelial BEAS-2B cells in response to LPS. J Endocrinol. 2013; 217(3):265-74. doi: 10.1530/JOE-12-0339 PMID: 23528477

70. Blank U, Madera-Salcedo IK, Danelli L, Claver J, Tiwari N, Sánchez-Miranda E, et al. Vesicular trafficking and signaling for cytokine and chemokine secretion in mast cells. Front Immunol. 2014; 5:453. doi: 10.3389/fimmu.2014.00453 PMID: 25295038 


\title{
Distribution of the stx1 and stx2 genes in Escherichia coli isolated from milk cattle according to season, age, and production scale in southwestern region of Goiás, Brazil
}

[Distribuição dos genes stx1 e stx2 em Escherichia coli isoladas de bovinos de leite de acordo com a estação, idade e escala de produção na região sudoeste de Goiás, Brasil]

\author{
M.R.A. Ferreira ${ }^{1,2}$, A.E. Stella ${ }^{1}$, E.G. Freitas-Filho ${ }^{1,3}$, T.S. Silva ${ }^{1}$, K.A. Nascimento ${ }^{1,4}$, \\ J.F.N. Pinto ${ }^{1}$, M. Dias ${ }^{1}$, C.N. Moreira ${ }^{1 *}$ \\ ${ }^{1}$ Universidade Federal de Goiás - Jataí, GO \\ ${ }^{2}$ Universidade Federal de Pelotas - Pelotas, RS \\ ${ }^{3}$ Universidade de São Paulo - São Paulo, SP \\ ${ }^{4}$ Universidade Estadual Paulista "Júlio de Mesquita Filho" - Jaboticabal, SP
}

\begin{abstract}
This study determined the distribution of stx 1 and stx2 genes in Escherichia coli isolated from dairy herds with regard to animal age, season, and farm production-scale, and analyzed the phylogenetic distribution of the groups A, B1, B2, and D of 276 isolates of bovine feces Shiga toxin-producing E. coli (STEC). The stxl profile was the most common, detected in $20.4 \%$ (202/990) of the isolates, followed by stx2 $(4.54 \%, 45 / 990)$ and stx $1+s t x 2(2.92 \%, 29 / 990)$. The stxl gene was detected more frequently in calves than in adult animals. In the dry season (winter), the presence of stx $1+s t x 2$ profile in cattle feces was higher than in the rainy season (summer), while no significant changes were observed between seasons for the stx 1 and stx 2 profiles. The most predominant phylogenetic groups in adult animals were B1, A, and D, while groups A and B1 prevailed in calves. Our data highlight the importance of identifying STEC reservoirs, since $7.5 \%$ of the tested isolates were positive for stx2, the main profile responsible for the hemolytic-uremic syndrome (HUS). Moreover, these microorganisms are adapted to survive even in hostile environments and can contaminate the food production chain, posing a significant risk to consumers of animal products.
\end{abstract}

Keywords: Shiga toxin-producing Escherichia coli (STEC), phylogenetic STEC groups, STEC reservoirs; Stx1, Stx2

\section{RESUMO}

Esse estudo determinou a distribuição dos genes stx1 e stx2 em Escherichia coli isolados de rebanhos leiteiros em relação a idade, estação e produção, e analisaram a distribuição filogenética dos grupos A, B1, B2 e D de 276 E. coli produtoras de toxina Shiga (STEC). O perfil stx1 foi mais comum, detectado em 20,4\% (202/990) dos isolados, seguido de stx2 (4,54\%, 45/990) e stx1+stx2 (2,92\%, 29/990). O gene stx 1 foi detectado mais frequentemente em bezerros que animais adultos. No período de seca (inverno), a presença do perfil stx1+stx2 nas fezes dos bovinos foi mais prevalente que no período chuvoso (verão), apesar de não haver diferença significativa entre estações para os perfis stx1 e stx2. Os grupos filogenéticos mais predominantes em animais adultos foram $B 1, A$ e $D$, enquanto grupos $A$ e $B 2$ prevaleceram em bezerros. Nossos dados enfatizam a importância de se detectar reservatórios de STEC já que 7,5\% dos isolados testados foram positivos para stx2, o perfil mais prevalente em casos de síndrome hemolítica-urêmica. Ademais, esses microorganismos são adaptados à sobreviver em ambientes hostis e contaminam a cadeia alimentar, levando a risco significativo para consumidores de alimentos de origem animal.

Palavras-chave: Escherichia coli produtora de toxina shiga (STEC), grupos STEC filogenéticos, reservatórios STEC, Stx1, Stx2

Recebido em 29 de março de 2017

Aceito em 17 de abril de 2018

* Autor para correspondência (corresponding author)

E-mail: cissanm@yahoo.com.br 


\section{INTRODUCTION}

Enteric disease-inducing Escherichia coli have been divided into pathotypes, based on their virulence factors and disease-causing mechanisms (Farrokh et al., 2013). Despite of this fact, the potent cytotoxic produced strains known as Shiga toxin (Stx) are defined as STEC (Shiga toxin-producing Escherichia coli) (Nataro and Kaper, 1998). STEC strains can cause hemorrhagic colitis (HC) and the hemolyticuremic syndrome (HUS), which have been related to the consumption of different types of foods, especially of bovine products. Healthy beef or dairy cattle are the largest reservoirs of several serotypes of STEC, including the serotypes O157 and non-O157 serotypes, and can be transmitted through contaminated water or food and by direct contact with feces of animal carriers (Chiang et al., 2011).

In cattle, STEC colonize the intestinal epithelium, especially in the mucosa adjacent to the anorectal junction, where they are present as commensal microbiota without causing damage to the host (Bolton, 2011). Apart from other factors, such as animal age, sex, and nutrition, the main factor repeatedly indicated as influencing the occurrence of STEC in feces is seasonality (Fernández et al., 2009; Jeon et al., 2013; Ferreira et al., 2014). The elimination in feces decreases dramatically in fall and winter, increases in spring, and peaks in the summer months (Van Donkersgoed et al., 1999; Arthur et al., 2009).

Stx 1 is a similar cytotoxin to that produced by Shigella dysenteriae serotype 1, but antigenically distinct (O'Brien and Holmes, 1987). The Stx2 cytotoxin has little similarity to Stx1 and Shiga toxin (Stx) from $S$. dysenteriae type 1. Also, Stx2 cannot be recognized and neutralized by the antibodies against the latter two cytotoxin (Scheutz et al., 2012). Stx1 and Stx2 are also known as verotoxins (VT), and in this study, cytotoxicity was tested in Vero cells derived from African green monkey kidney (Cercopithecus aethiops; Konowalchuk et al., 1977). The most important STEC subgroup contains the called strains enterohemorrhagic $E$. coli (EHEC) (Nataro and Kaper, 1998). EHEC subgroup is able to colonize the human intestinal mucosa and produce an effacing lesion by a type III secretion system (McDaniel et al., 1995;
Kaper et al., 2004). This subgroup is an important etiologic agent of diseases in humans, including diarrhea, HC, HUS and renal insufficiency (Repetto, 20005; Karch et al., 2005).

The state of Goiás plays an important role in dairy farming in Brazil and is currently ranked as the sixth largest milk-producing state of the country (IBGE, 2017). Since cattle is the main reservoir of STEC, it is important to understand the potential pathogenic risk of STEC isolates and their impact on public health in the state supply chain. Previously, other studies described the prevalence of STEC isolated from healthy cattle in 34 dairy farms localized in the southwestern region of Goiás state, Brazil. It was also evaluated the main risk factors for STEC infection (Freitas-Filho et al., 2014; Ferreira et $a l ., 2014)$. The aim of the present study was to evaluate the distribution of stx 1 and stx 2 genes in $E$. coli isolated from healthy cattle, taking into account the season, animal age, and farm production scale, as well as to analyze the pathogenic potential of isolated STEC by the phylogenetic classification (Clermont et al., 2000).

\section{MATERIAL AND METHODS}

Nine hundred and ninety $E$. coli isolates used in this study were obtained from stool samples of healthy cattle (198 animals) from 34 dairy farms located in the municipality of Jataí, Goiás, Brazil. The 34 farms were divided into three production-scale groups: Low output (100L/milk/day); medium output (100 to 400L/milk/day); and high output (overt to 400L/milk/day). Rectal swab samples were collected and placed in Stuart transport medium (Mumbai, India). The samples were inoculated on MacConkey agar and incubated for $24 \mathrm{~h}$ at $37^{\circ} \mathrm{C}$. Colonies with growth characteristics of $E$. coli (five per plate) were subcultured and identified by biochemical tests of lactose fermentation, indole production, methyl-red and Voges-Proskauer reactions, citrate utilization, urease production, and by the production of hydrogen sulphide $\left(\mathrm{H}_{2} \mathrm{~S}\right)$.

Whole-cell DNA was extracted as previously described (Keskimaki et al., 2001). The PCR reactions were performed in a total volume of $25 \mu \mathrm{L}$ mixture with $2.5 \mu \mathrm{L}$ of the extracted DNA, 
$10 \mathrm{pmol}$ of each primer: universal primer 16SrRNA (internal control) forward (F) (5'CCCCCTGGACGAAGACTGAC-3') and reverse (R) (5'-ACCGCTGGCAACAAAGGATA-3'); stxl-F (5'TCTCAGTGGGCGTTCTTATG-3') and stxl-R (5'TACCCCCTCAACTGCTAATA-3') (Wang et al., 2002); st $x 2$-F (5'-GGCACTGTCTGAAACTGCTCC-3') and stx2-R (5'-GGCACTGTCTGAAACTGCTCC-3') (Paton and Paton, 1998); and GoTaq ${ }^{\circledR}$ DNA polymerase following manufacturer's instructions (Promega, Madison, Wisconsin, USA). E. coli O157:H7 EDL933 and Klebsiella pneumoniae ATCC BAA 1705 were used as positive and negative controls, respectively.

The phylogenetic groups were determined in simultaneous amplification tests (PCR-triplex) to identify the genes $c h u A, y j a A$ and fragment TspE4.C2. The oligonucleotide pairs used were chuA-F (5'-GACGAACCAACGGTCAGGAT-3') and chuA-R (5'-TGCCGCCAGTACCAAAGACA-3'), yjaAF (5'-TGAAGTGTCAGGAGACGCTG-3') and yjaA-R (5'-ATGGAGAATGCGTTCCTCAAC-3'), and TspE4.C2F (5'-GAGTAATGTCGGGGCATTCA-3') and TspE4.C2-R (5'-CGCGCCAACAAAGTATTACG-3'). The groups B2 $\left(\right.$ chuA $\left.A^{+} / y j a A^{+}\right), \mathrm{D}\left(\right.$ chuA $\left.^{+} / y j a A^{-}\right)$, B1 (chuA-/TspE4.C2 $\left.{ }^{+}\right)$, and A (chuA-/TspE4.C2 ) were classified phylogenetically, as proposed by to Clermont et al. (2000). Comparative statistical data analysis was performed by Fisher's exact test.

In the analysis of possible risk factors for STEC presence in cattle, all data were analyzed using the Statistical Analysis System ("Statistical..., 2010) v.9.0, at $5 \%$ probability. The effects of animal age, season, and farm output scale on STEC occurrence were analyzed by logistic regression with dichotomous response, using the
Wald and odds ratio tests, considering all effects in the full model, with subsequent modeling, after eliminating the non-significant effects.

The study procedures were carried out and the animals treated according to international standards and in compliance with the ethical principles of animal experimentation established by the Colégio Brasileiro de Experimentação Animal (COBEA) (protocol: 206/2009/COEP/ PRPPG/UFG).

\section{RESULTS}

The genotyping of the $990 \mathrm{E}$. coli isolates showed that $27.9 \%(276 / 990)$ of the isolates carried one or more of the investigated stx 1 and/or stx 2 genes. stx 1 profile was the most common and was presented in $20.4 \%(202 / 990)$ of the isolates, followed by stx $2(4.54 \% ; 45 / 990)$ and stx $1+s t x 2$ profile $(2.92 \% ; 29 / 990)$. The percentage of STEC-carrying animals was $45.4 \%$ (90/198). The target profiles were detected more frequently in calves than in adult animals, although the variability was not significant (Table 1). The season had an influence in STEC prevalence. The $s t x 1+s t x 2$ profile demonstrated higher percentage in cattle isolates in the dry season (winter) than in the rainy season (summer), while no significant changes between seasons were observed for stx 1 and stx 2 profiles analysis.

The 276 STEC strains were divided into four groups (B2, D, B1, and A) by phylogenetic characterization and distributed according to the season and animal age (Table 2). The pathogenic group D was most prevalent in the winter season. There was no difference between the profile distribution of phylogenetic groups in cows and calves.

Table 1. Prevalence of Escherichia coli isolated from dairy cattle, carrying stx1, stx2 or stxl+stx2 genes, according to the age, season and farm production scale

\begin{tabular}{ccccccccc}
\hline stx genotype & \multicolumn{2}{c}{ AGE $^{\mathrm{a}}$} & \multicolumn{2}{c}{ Season $^{\mathrm{a}, \mathrm{b}}$} & \multicolumn{2}{c}{ Farm Production Scale } & \multicolumn{2}{c}{ Total } \\
\hline stx 1 & Cow & Calf & Winter & Summer & Low & Medium & High & \\
stx 2 & 60 & 142 & 91 & 111 & $95 \mathrm{~A}$ & $91 \mathrm{~A}$ & $16 \mathrm{~B}$ & 202 \\
stx $1+$ st $x 2$ & 15 & 30 & 24 & 21 & $19 \mathrm{~A}$ & $21 \mathrm{~A}$ & $5 \mathrm{~B}$ & 45 \\
Total & 5 & 24 & $21 \mathrm{~A}$ & $8 \mathrm{~B}$ & $21 \mathrm{~A}$ & $8 \mathrm{~B}$ & $0 \mathrm{C}$ & 29 \\
\hline & 80 & 196 & 136 & 140 & 135 & 120 & 21 & 276 \\
\hline
\end{tabular}

${ }^{a}$ Non-significant $(\mathrm{P}>0.01)$ for all genes according to the animal age, and for stxl and stx2 genes according to the season.

${ }^{\mathrm{b}}$ Different letters in a row indicate significantly different $(\mathrm{P}<0.01)$, and same letters in a row statistically non significantly different values. 
Table 2. Prevalence of the phylogenetic groups B2, D, B1, and A of STEC strains isolated from dairy cattle, according to the season and animal age

\begin{tabular}{cccccc}
\hline \multirow{2}{*}{ Phylogenetic group } & \multicolumn{2}{c}{ SEASON } & \multicolumn{2}{c}{ AGE } & \multirow{2}{*}{ Total } \\
\cline { 2 - 4 } & Summer & Winter & Cow & Calf & \\
\hline Group B2 $\left(\right.$ chuA $\left.A^{+} / y j a A^{+}\right)$ & 2 & 0 & 1 & 1 & 2 \\
Group D $\left(\right.$ chuA $\left./ y j a A^{-}\right)$ & 11 & 51 & 18 & 44 & 62 \\
Group B1 $\left(\right.$ chuA $/ T$ TspE4.C2 $\left.2^{+}\right)$ & 76 & 54 & 43 & 87 & 130 \\
Group A $\left(\right.$ chuA $\left./ T s p E 4 . C 2^{-}\right)$ & 51 & 31 & 18 & 64 & 82 \\
Total & 140 & 136 & 80 & 196 & 276 \\
\hline
\end{tabular}

\section{DISCUSSION}

Some STEC serotypes can induce human diseases, although not all serotypes found in cattle or foods are associated with severe disease in humans. Several STEC outbreaks have been reported, and one fatal occurred in Sakayin, Japan, in July 1996, with 8,000 cases and 6 deaths (Vidovic et al., 2011). In the present study, an extremely high number of STECcarrying animals (45.4\%) was detected. The rates of prevalence in cattle have been determined for decades; however, comparisons between these studies are hampered by the differences in sampling and methodologies (Chase-Topping $e t$ al., 2008).

Some factors that contribute to the presence and spread of STEC in a herd are the management practices, stress, diet, population density, geographic region, and season (Fernández et al., 2009; Jeon et al., 2013; Ferreira et al., 2014). The seasonal pattern with peaks in the summer leads to a similar variation in the human disease associated with the agent (Ostroff et al., 1989). However, in the present study, a greater isolation of STEC was detected in the winter (dry season), contrasting with Dunn et al. (2004), whom reported a higher STEC frequency in the summer and lower frequency in the winter. The greater presence of isolates carrying both stxl and stx2 genes in the cold and dry months can be related to the pathogenicity, once better adapted strains to cold and drought stress could be more adapted to survive in hostile environments (Allen et al., 2008), e.g., in refrigerated foods of animal origin. Foods of animal origin (milk and meat) were identified as the most important source of STEC entry into the food chain (Martin and Beutin, 2011). In cattle stool samples analyzed at slaughter in an abattoir, Fukushima and Seki (2004) determined a prevalence of $37.5 \%$ of STEC isolates.
The present study demonstrated that young animals could be major source of STEC excretion in the environment. The same conclusion was also demonstrated by Werber $e t$ al. (2007), who stated that young animals have a greater prevalence of colonization with stx profiles of STEC than adult animals, and the prevalence in calves older than two months is higher than in younger calves. The results of $70.3 \%$ stxl-positive isolates and $29.7 \%$ stx 2 positive isolates found in the present study confirmed the findings demonstrated by Andrade et al. (2012) and Vargas-Jr et al. (2017) in healthy calves in, respectively, Minas Gerais and Rio Grande do Sul states, Brazil.

Our data identified a significantly higher percentage $(92.4 \%$; $255 / 276)$ of all investigated STEC strains in cattle excretion on the medium and small-scale farms. These results demonstrate that the inspection of products derived from these farms needs to be intensified, despite of the increased contamination pressure of milk as well as of meat (Martin and Beutin, 2011). It was also reported that STEC prevalence is greater in food from organic than from conventional farms. This is a matter of concern, because STEC, as much as non-pathogenic E. coli, are components of the normal intestinal flora of cattle and the effect of any treatment to control STEC excretion would be limited (Gill and Gill, 2010).

Studies have shown that extraintestinal pathogenic E. coli normally belong to groups B2 and $\mathrm{D}$, whereas pathogenic isolates are classified as groups A, B1 and D (Pupo et al., 1997; Picard et al., 1999). The data of our study show that group B1 was predominant $(54.3 \%)$ in the summer, followed by groups A, D and B2 (with $36.4 \%, 7.8 \%$ and $1.4 \%$, respectively). In winter, there was similarity between B1 $(39.7 \%)$ and D (37.5\%), with lower prevalence of group A (22.8\%), while no B2 isolates were found. Previously, studies done by Escobar-Páramo et 
al. (2004) showed that the prevalence of group B2 was greater in the temperate regions of France than in tropical countries such as Benin, French Guyana and Colombia. The higher prevalence of B1 groups in both periods confirmed the findings demonstrated by Unno et al. (2009), whom reported a higher prevalence of this group in their study. However, our study contradicts the hypothesis that $E$. coli isolates from tropical areas belong mostly to group A (Escobar-Páramo et al., 2004), since in the tropical southeastern region of Brazil, the prevalence of group B1 was higher in both summer and winter, and the prevalence of group A increased in the colder season.

Correlating the phylogenetic groups with the animal age, the prevalence of isolates from adult animals was highest for group B1 (53.8\%), followed by group A (22.5\%), and the prevalence of group D isolates was similar in both age categories $(22.5 \%)$. In calves as well as in adult animals, there was a higher prevalence of group B1 (44.4\%), followed by group A $(32.6 \%)$. In phylogenetic studies of STEC/EHEC/eae $e^{+}$isolates, Tramuta et al. (2008) also observed a higher prevalence of group B1 (38.7\%), followed by group A $(35.5 \%)$ in calves. Similar data were obtained in the study carried from Minas Gerais state, Brazil. Coura et al. (2017) demonstrated that STEC and EHEC isolates from healthy and diarrheic calf feces belonged mainly to phylogenetic groups B1 and A.

Our data highlight the importance of pathogenic E. coli reservoirs, since $7.5 \%$ of the tested isolates were positive for $s t x 2$, which is mainly responsible for HUS. Moreover, these microorganisms, adapted to survive in hostile environments, with significant levels of pathogenic strains excreted in the colder and dry months, can reach the food production chain, representing a significant risk to consumers of animal products.

\section{ACKNOWLEDGEMENTS}

The authors are indebted to the farm owners and workers for their generous assistance and cooperation with sampling. This study was supported by the grant 503886/2009-2 from Conselho Nacional de Desenvolvimento Científico e Tecnológico (CNPq).

\section{REFERENCES}

ALLEN, K.J.; LEPP, D.; MCKELLAR, R.C.; GRIFFITHS, M.W. Examination of stress and virulence gene expression in Escherichia coli O157:H7 using targeted microarray analysis. Foodborne Pathog. Dis., v.5, p.437-447, 2008.

ANDRADE, G.I.; COURA, F.M.; SANTOS, E.L.S. et al. Identification of virulence factors by multiplex PCR in Escherichia coli isolated from calves in Minas Gerais, Brazil. Trop. Anim. Health Prod., v.44, p.1783-1790, 2012.

ARTHUR, T.M.; KEEN, J.E.; BOSILEVAC, J.M. et al. Longitudinal study of Escherichia coli O157:H7 in a beef cattle feedlot and role of highlevel shedders in hide contamination. Appl. Environ. Microbiol., v.75, p.6515-6523, 2009.

BOLTON, D.J. Verocytotoxigenic (Shiga Toxin-Producing) Escherichia coli: virulence factors and pathogenicity in the farm to fork paradigm. Foodborne Pathog. Dis., v.8, p.357$65,2011$.

CHASE-TOPPING, M.; GALLY, D.; LOW, C. et al. Super-shedding and the link between human infection and livestock carriage of Escherichia coli O157. Nat. Rev. Microbiol., v.6, p.904-912, 2008.

CHIANG, S.M.; DONG, T.; EDGE, T.A.; SCHELLHORN, H.E. Phenotypic diversity caused by differential Rpos activity among environmental Escherichia coli isolates. Appl. Environ. Microbiol., v.77, p.7915-7923, 2011.

CLERMONT, O.; BONACORSI, S.; BINGEN, E. Rapid and simple determination of the Escherichia coli phylogenetic group. Appl. Environ. Microbiol., v.66, p.4555-4558, 2000.

COURA, F.M.; DINIZ, S.A.; MUSSI, J.M.S. et al. Characterization of virulence factors and phylogenetic group determination of Escherichia coli isolated from diarrheic and non-diarrheic calves from Brazil. Folia Microbiol., v.62, p.139-144, 2017.

DUNN, J.R.; KEEN, J.E.; THOMPSON, R.A. Prevalence of shiga-toxigenic Escherichia coli O157:H7 in adult dairy cattle. J. Am. Vet. Med. Assoc., v.224, p.1151-1158, 2004. ESCOBARPÁRAMO, P.; GRENET, K.; LE MENAC'H, A. et al. Large-scale population structure of human commensal Escherichia coli isolates. Appl. Environ. Microbiol., v.70, p.5698-5700, 2004. 
Instituto Brasileiro de Geografia e Estatística, 2017. Estatística de produção pecuária. [Rio de Janeiro]. Disponível em: $<\mathrm{ftp}$ //ftp.ibge.gov.br/Producao_Pecuaria/Fascicu lo_Indicadores_IBGE/abate-leite-couro-

ovos_201701caderno.pdf>. Acessado em: 12 jan. 2018.

FARROKH, C.; JORDAN, K.; AUVRAY, F. et al. Review of Shiga-toxin-producing Escherichia coli (STEC) and their significance in dairy production. Int. J. Food Microbiol., v.162, p.190$212,2013$.

FERNÁNDEZ， D.; RODRÍGUEZ， E.M.; ARROYO, G.H. et al. Seasonal variation of Shiga toxin-encoding genes (stx) and detection of E. coli $\mathrm{O} 157$ in dairy cattle from Argentina. $J$. Appl. Microbiol., v.106, p.1260-1267, 2009.

FERREIRA, M.R.A.; FILHO-FREITAS, E.G.; PINTO, J.F.N. et al. Isolation, prevalence, and risk factors for infection by shiga toxinproducing Escherichia coli (STEC) in dairy cattle. Trop. Anim. Health Prod., v.46, p.635639, 2014

FREITAS FILHO, E.G.; FERREIRA, M.R.A.; PINTO, J.F.N.; CONCEIÇÃO, F.R.; MOREIRA, C.N. Enterohemorrhagic Escherichia coli O157:H7 from healthy dairy cattle in Mid-West Brazil: occurrence and molecular characterization. Braz. J. Vet. Res., v.34, p.24-28, 2014.

FUKUSHIMA, H.; SEKI, R. High numbers of Shiga toxin-producing Escherichia coli found in bovine faeces collected at slaughter in Japan. FEMS Microbiol. Lett., v.238, p.189-197, 2004.

GILL, A.; GILL, C.O. Non-O157 verotoxigenic Escherichia coli and beef: a Canadian perspective. Can. J. Vet. Res., v.74, p.161-169, 2010.

JEON, S.J.; ELZO, M.; DILORENZO, N. et al. Evaluation of animal genetic and physiological factors that affect the prevalence of Escherichia coli $\mathrm{O} 157$ in cattle. PlosOne, v.8, p.e55728, 2013.

KAPER, J.B.; NATARO, J.P.; MOBLEY, H.L. Pathogenic Escherichia coli. Nat. Rev. Microbiol., v.2, p.123-40, 2004.
KARCH, H.; TARR, P.I.; BIELASZEWSKA, M. Enterohaemorrhagic Escherichia coli in human medicine. Int. J. Med. Microbiol., v.295, p.405-418, 2005.

KESKIMAKI, M.; EKLUND, M.; PERSONEN, H. et al. EPEC, EAEC and STEC in stool specimens: prevalence and molecular epidemiology of isolates. Diagn. Microbiol. Infect. Dis., v.40, p.151-156, 2001.

KONOWALCHUK, J.; SPIERS, J.L.; STARVIC, S. Vero response to a cytotoxin of Escherichia coli. Infect. Immun., v.18, p.775779, 1977.

MARTIN, A.; BEUTIN, L. Characteristics of shiga toxin-producing Escherichia coli from meat and milk products of different origins and association with food producing animals as main contamination sources. J. Food Protect., v.146, p.99-104, 2011.

MCDANIEL, T.K.; JARVIS, K.G.; DONNENBERG, M.S.; KAPER, J.B. A genetic locus of enterocyte effacement conserved among diverse enterobacterial pathogens. Proc. Natl. Acad. Sci. USA, v.92, p.1664-1668, 1995.

NATARO, J.P.; KAPER, J.B. Diarrheagenic Escherichia coli. Clin. Microbiol. Rev., v.11, p.142-201, 1998.

O'BRIEN, A.D.; HOLMES, R.K. Shiga and Shiga-like toxins. Microbiol. Rev., v.51, p.206220, 1987.

OSTROFF, S.M.; KOBAYASHI, J.M.; LEWIS, J.H. Infection with Escherichia coli $\mathrm{O} 157: \mathrm{H} 7$ in Washington State. The first year of statewide disease surveillance. J. Am. Med. Assoc., v.262, p.355-359, 1989.

PATON, A.W.; PATON, J.C. Detection and characterization of shiga toxigenic Escherichia coli by using multiplex PCR assays for $s t x 1$, stx 2 , eae A, enterohemorragic E. coli hlyA, rfb $b_{o 111}$ and

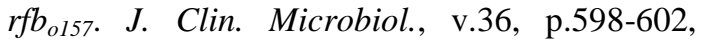
1998.

PICARD, B.; GARCIA, J.S.; GOURIOU, S. et al. The link between phylogeny and virulence in Escherichia coli extraintestinal infection. Infect. Immun., v.67, p.546-553, 1999. 
PUPO, G.M.; KARAOLIS, D.K.R.; LAN, R.; REEVES, P.R. Evolutionary relationships among pathogenic and nonpathogenic Escherichia coli strains inferred from multilocus enzyme electrophoresis and mdh sequence studies. Infect. Immun., v.65, p.2685-2692, 1997.

REPETTO, H.A. Long-term course and mechanisms of progression of renal disease in hemolytic uremic syndrome. Kidney Int., v.68, Suppl.97, p.102-106, 2005.

SCHEUTZ, F.; TEEL, L.D.; BEUTIN, L.; PIÉRARD, D. et al. Multicenter evaluation of a sequence-based protocol for subtyping Shiga toxins and standardizing Stx nomenclature. $J$. Clin. Microbiol., v.50, p.2951-2963, 2012.

STATISTICAL analysis system. Version 9.0. Cari: SAS, 2010.

TRAMUTA, C.; ROBINO, P.; NEBBIA, P. Phylogenetic back- ground of attaching and effacing Escherichia coli isolates from animals. Vet. Res. Commun., v.32, p.433-437, 2008.

UNNO, T.; HAN, D.; JANG, J.; LEE, S. et al. Absence of Escherichia coli phylogenetic group B2 strains in humans and domesticated animals from Jeonnam province, Republic of Korea. Appl. Environ. Microbiol., v.75, p.5659-5666, 2009.
VAN DONKERSGOED, J.; GRAHAM, T.; GANNON, V. The prevalence of verotoxins, Escherichia coli O157:H7, and Salmonella in the feces and rumen of cattle at processing. Can. Vet. J., v.40, p.332-338, 1999.

VARGAS-JÚNIOR， S.F.; CUNHA， R.C.; PEREIRA, D.I.B. et al. Identificação de fatores de virulência de isolados de Escherichia coli oriundos de fezes de bezerros na região Sul do Brasil. Acta Sci. Vet., v.45, p.1467, 2017.

VIDOVIC, S.; MANGALAPPALLI-ILLATHU, A.K.; KORBER, D.R. Prolonged cold stress response of Escherichia coli $\mathrm{O} 157$ and the role of RpoS. Int. J. Food Microbiol., v.146, p.163169, 2011.

WANG, G.; CLARK, C.G.; RODGER, F.G. Detection in Escherichia coli of the genes encoding the major virulence factors, the genes defining the 0157:H7 serotype, and components of the type 2 Shiga toxin family by Multiplex PCR. J. Clin. Microbiol., v.40, p.3613-3619, 2002.

WERBER, D.; BEHNKE, S.C.; FRUTH, A. et al. Shiga toxin-producing Escherichia coli infection in Germany-different risk factors for different age groups. Am. J. Epidemiol., v.165, p.425-434, 2007. 